\title{
HYDROLOGY OF AREA 61, \\ NORTHERN GREAT PLAINS AND \\ ROCKY MOUNTAIN COAL PROVINCES, COLORADO AND NEW MEXICO
}

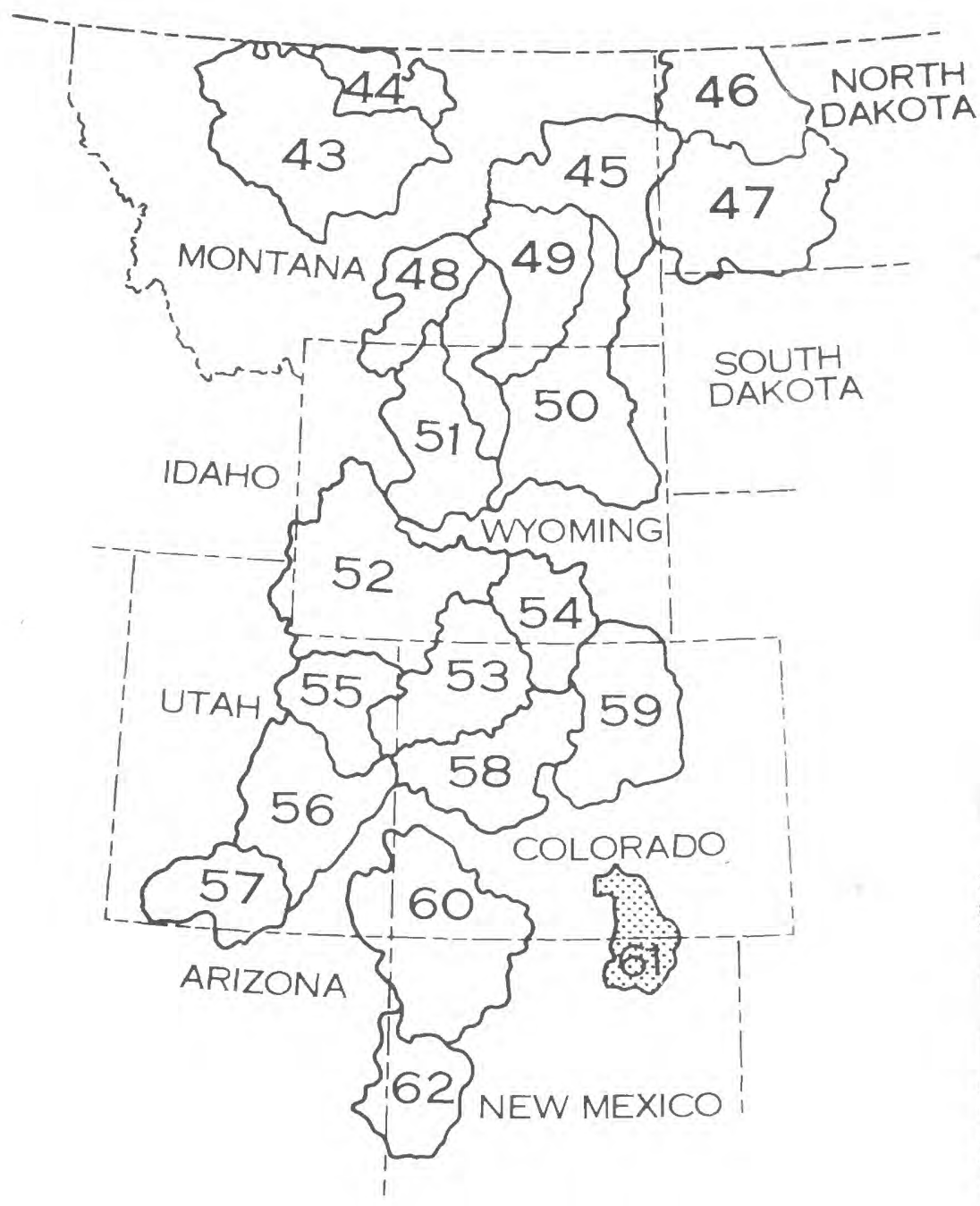

- HUERFANO RIVER

- PURGATOIRE RIVER

- CANADIAN RIVER

- VERMEJO RIVER

LNITED STATES DEPARTMENT OF THE INTERIOR GEOLOGICAL SURVEY 


\section{HYDROLOGY OF AREA 61, NORTHERN GREAT PLAINS AND ROCKY MOUNTAIN COAL PROVINCES, COLORADO AND NEW MEXICO}

BY

P.O. ABBOTT, ARTHUR L. GELDON, DOUG CAIN, ALAN P. HALL, AND PATRICK EDELMANN

U.S. GEOLOGICAL SURVEY

WATER-RESOURCES INVESTIGATIONS

OPEN-FILE REPORT 83-132 


\title{
UNITED STATES DEPARTMENT OF THE INTERIOR
}

\author{
WILLIAM P. CLARK. SICCRETARY
}

\section{GEOLOGICAL SURVEY}

Dallas L. Peck, Director

For additional information write to:

District Chief

U.S. Geological Survey

Water Resources Division

Building 53, Denver Federal Center

Mail Stop 415, Box 25046

Lakewood, Colorado 80225 


\section{CONTENTS}

Page

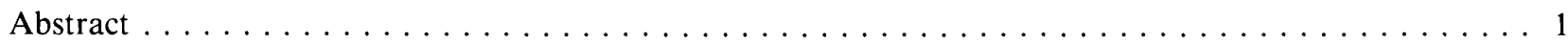

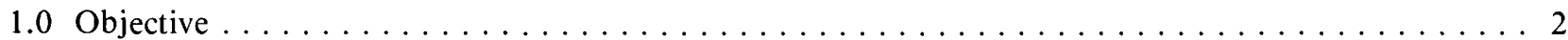

F. A. Kilpatrick and P. O. Abbott

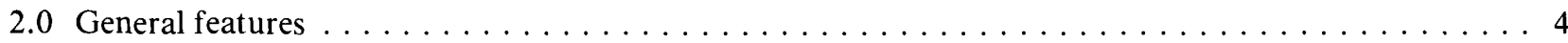

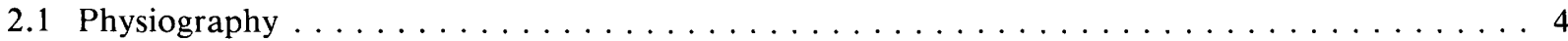

P. O. Abbott

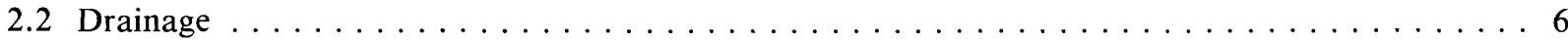
P. O. Abbott

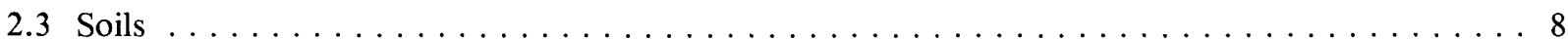

P. O. Abbott

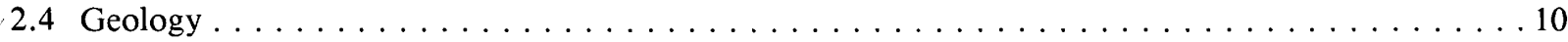

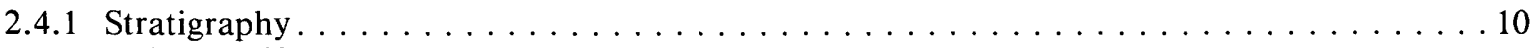

Arthur L. Geldon

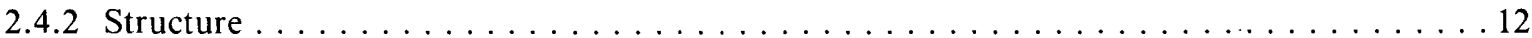

Arthur L. Geldon

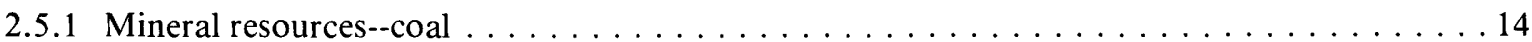
P. O. Abbott

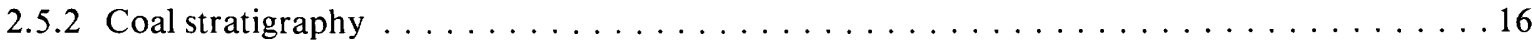
Arthur L. Geldon

2.5.3 Hydrologic problems related to coal mining $\ldots \ldots \ldots \ldots \ldots \ldots$ Arthur L. Geldon

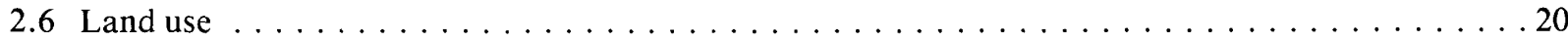

P. O. Abbott

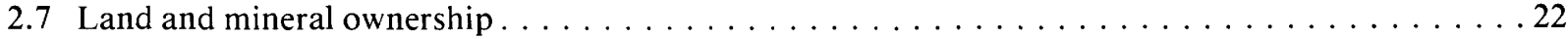
P. O. Abbott

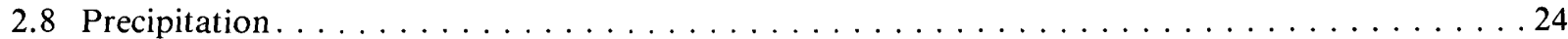
P. O. Abbott

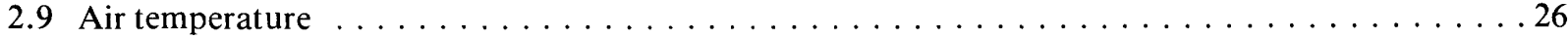
P. O. Abbott

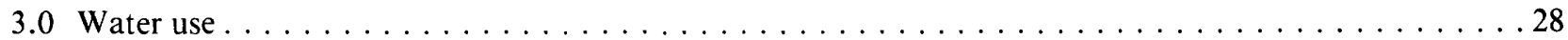

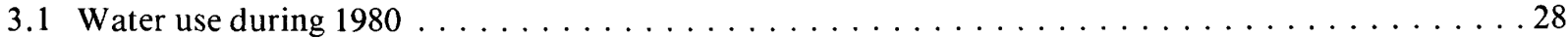
P. O. Abbott

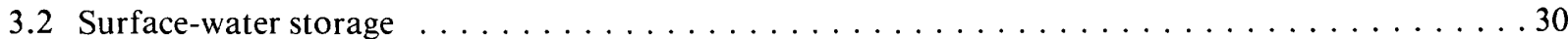
P. O. Abbott

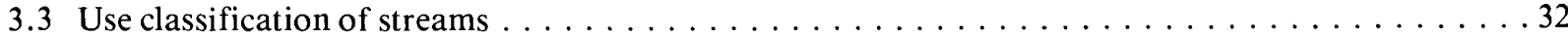
Doug Cain

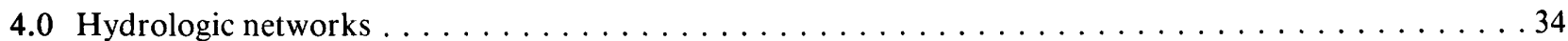

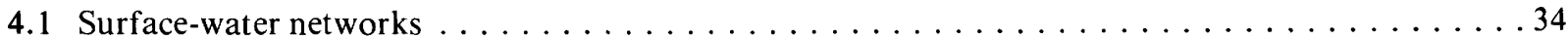

P. O. Abbott, Doug Cain, and Patrick Edelmann 


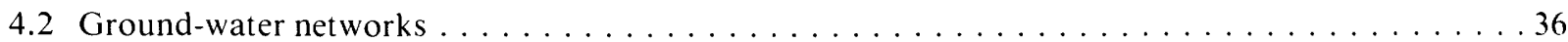
Arthur L. Geldon

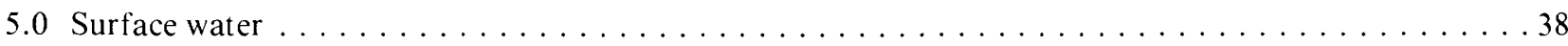

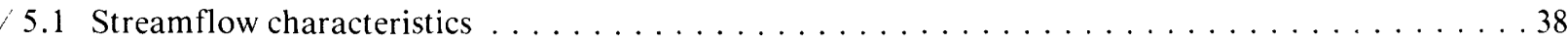
P. O. Abbott

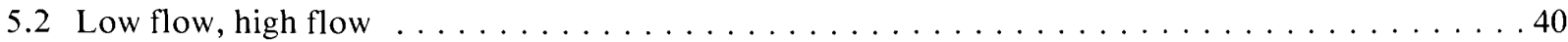
P. O. Abbotl and Alan P. Hall

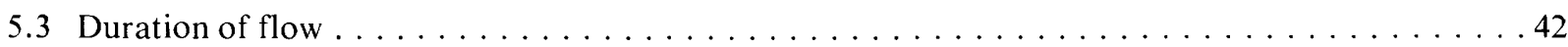
Alan P. Hall

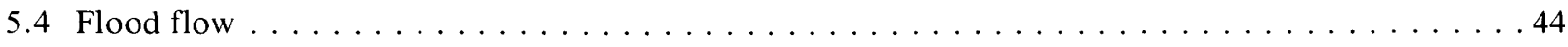

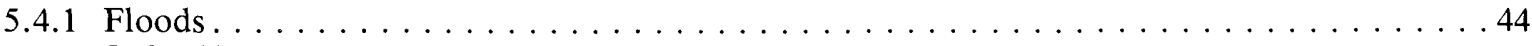
P. O. Abbott

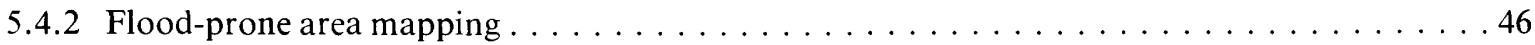
P. O. Abbott

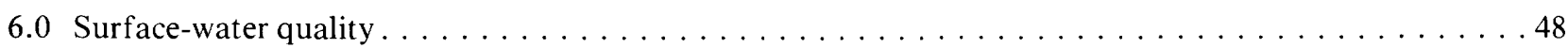

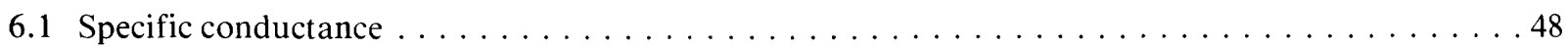

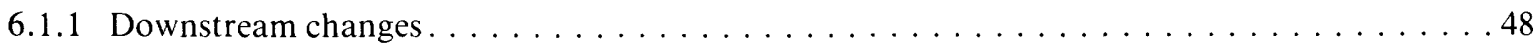
Doug Cain and Alan P. Hall

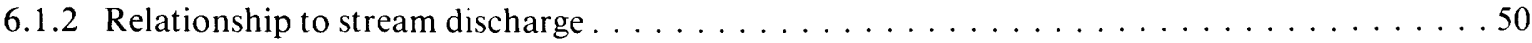
Doug Cain and Alan P. Hall

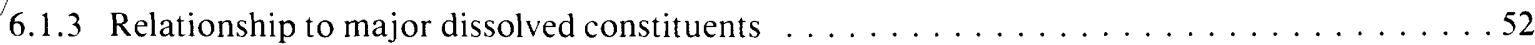
Alan P. Hall and Doug Cain

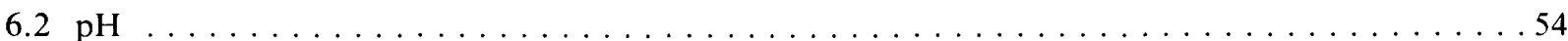

Doug Cain and Alan P. Hall

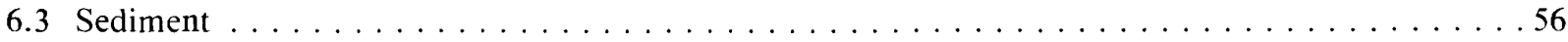

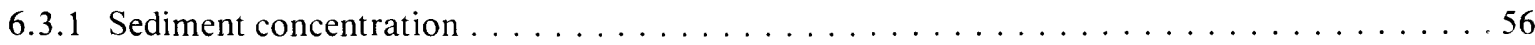
Alan P. Hall and Doug Cain

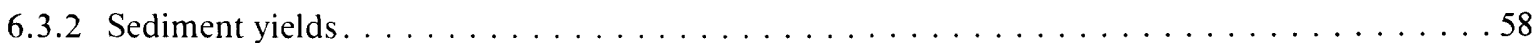
Alan P. Hall and Doug Cain

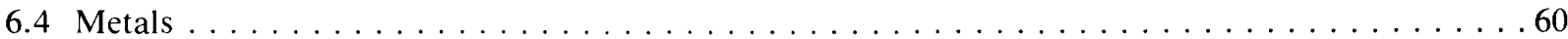
Alan P. Hall and Doug Cain

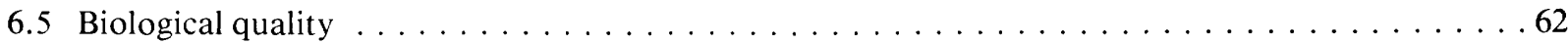
Patrick Edelmann

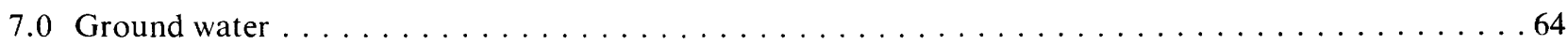

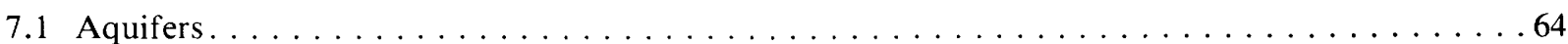
Arthur L. Geldon

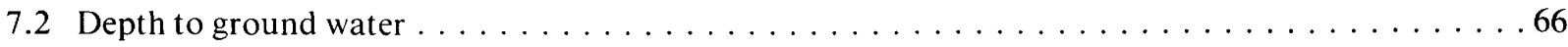
Arthur L. Geldon

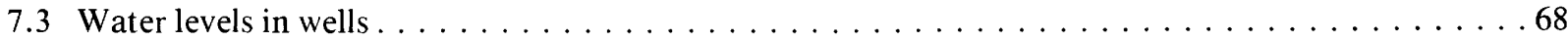
Arthur L. Geldon

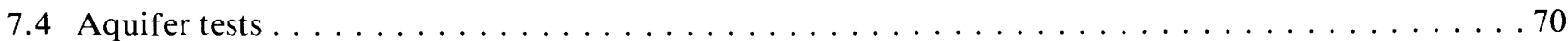
Arthur L. Geldon

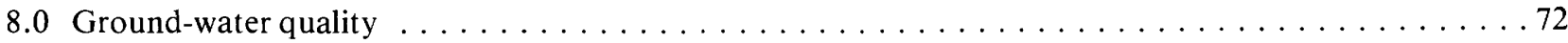

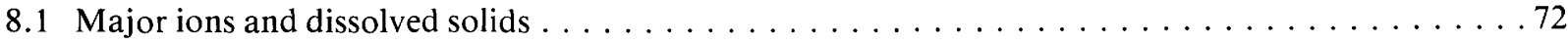
Arthur L. Geldon

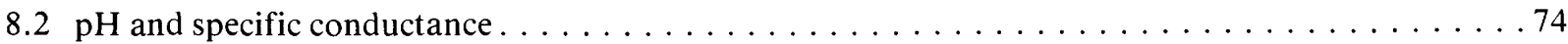
Arthur L. Geldon 


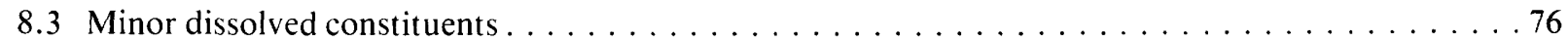
Arthur L. Geldon

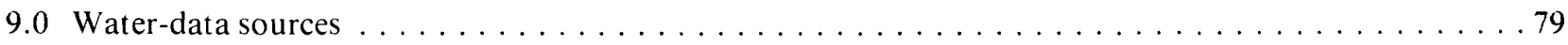

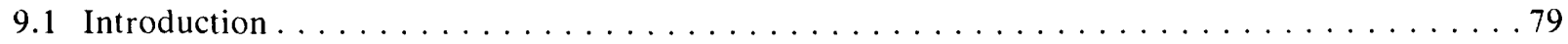

9.2 National Water Data Exchange (NAWDEX) $\ldots \ldots \ldots \ldots \ldots \ldots \ldots \ldots \ldots \ldots \ldots \ldots \ldots \ldots \ldots \ldots$

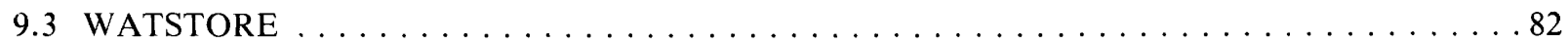

9.4 Index to water-data activities in coal provinces $\ldots \ldots \ldots \ldots \ldots \ldots \ldots \ldots \ldots \ldots$

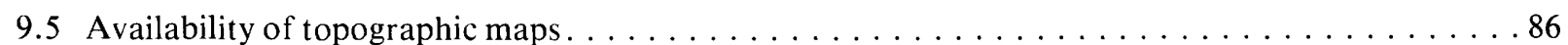

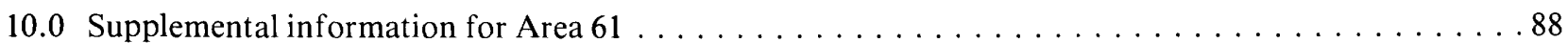

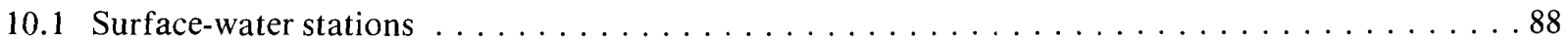

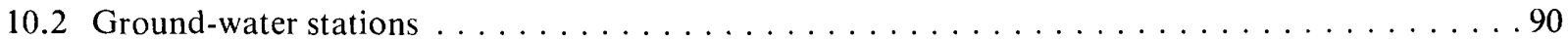

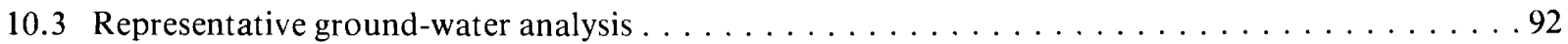

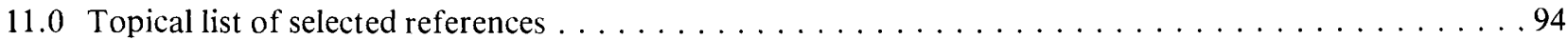




\section{FACTORS FOR CONVERTING INCH-POUND UNITS TO INTERNATIONAL SYSTEM OF UNITS (SI)}

\section{For the convenience of readers who may want to use the International System of Units (SI), the data may be converted by using the following factors:}

\section{Multiply}

inch (in.)

inch per hour (in/h)

foot (ft)

foot per mile $(\mathrm{ft} / \mathrm{mi})$

mile (mi)

square mile $\left(\mathrm{mi}^{2}\right)$

acre

acre-foot (acre-ft)

acre-foot per year (acre-ft/yr)

gallon per minute (gal/min)

cubic foot $\left(\mathrm{ft}^{3}\right)$

cubic foot per second $\left(\mathrm{ft}^{3} / \mathrm{s}\right)$

cubic foot per second

per square mile $\left[\left(\mathrm{ft}^{3} / \mathrm{s}\right) / \mathrm{mi}^{2}\right]$

ton, short

ton per square mile per

year $\left[\left(\right.\right.$ ton $\left.\left./ \mathrm{mi}^{2}\right) / \mathrm{yr}\right]$

foot per day (ft/d)

foot squared per day $\left(\mathrm{ft}^{2} / \mathrm{d}\right)$

gallon per minute per foot $[(\mathrm{gal} / \mathrm{min}) / \mathrm{ft}]$

micromho per centimeter $(\mu \mathrm{mho} / \mathrm{cm})$

\section{By}

25.4

25.4

0.3048

0.1890

1.609

2.590

0.4047

$1.233 \times 10^{-3}$

$1.233 \times 10^{-3}$

0.06309

0.02832

0.02832

0.01760

0.9072

0.5638

0.3048

0.0929

0.2070

100

\section{To obtain}

millimeter $(\mathrm{mm})$

millimeter per hour $(\mathrm{mm} / \mathrm{h})$

meter (m)

meter per kilometer $(\mathrm{m} / \mathrm{km})$

kilometer $(\mathrm{km})$

square kilometer $\left(\mathrm{km}^{2}\right)$

hectare (ha)

cubic hectometer $\left(\mathrm{hm}^{3}\right)$

cubic hectometer per year $\left(\mathrm{hm}^{3} / \mathrm{a}\right)$

liter per second $(\mathrm{L} / \mathrm{s})$

cubic meter $\left(\mathrm{m}^{3}\right)$

cubic meter per second $\left(\mathrm{m}^{3} / \mathrm{s}\right)$

cubic meter per second per square kilometer $\left[\left(\mathrm{m}^{3} / \mathrm{s}\right) / \mathrm{km}^{2}\right]$

megagram $(\mathrm{Mg})$

megagram per square kilometer per year $\left[\left(\mathrm{Mg} / \mathrm{km}^{2}\right) / \mathrm{a}\right]$

meter per day $(\mathrm{m} / \mathrm{d})$

meter squared per day $\left(\mathrm{m}^{2} / \mathrm{d}\right)$

liter per second per meter $[(\mathrm{L} / \mathrm{s}) / \mathrm{m}]$

microsiemens per meter $(\mu \mathrm{S} / \mathrm{m})$

${ }^{\circ} \mathrm{C}=\left({ }^{\circ} \mathrm{F}-32\right) \times 5 / 9$

${ }^{\circ} \mathrm{F}=\left({ }^{\circ} \mathrm{C} \times 9 / 5\right)+32$

National Geodetic Vertical Datum of 1929 (NGVD of 1929): A geodetic datum derived from a general adjustment of the first-order level nets of both the United States and Canada, formerly called mean sea level. NGVD of 1929 is referred to as sea level in this report. 
HYDROLOGY OF AREA 61, NORTHERN GREAT PLAINS AND ROCKY MOUNTAIN COAL PROVINCES, COLORADO AND NEW MEXICO

\author{
BY \\ P.O. ABbotT, ARTHuR L. GELDON, DOUg CAIN, ALAN P. HALL, \\ AND PATRICK EDELMANN
}

\begin{abstract}
Area 61, one of 20 hydrologic areas of the Northern Great Plains and Rocky Mountain Coal Provinces, is located north and south of the Colorado-New Mexico State boundary and includes the Raton Mesa coal region. The Huerfano, the Apishapa, the Purgatoire, the Canadian, the Vermejo, and the Cimarron Rivers are the principal streams draining the region; all are tributaries of the Arkansas River.
\end{abstract}

Abstract

Geologically, the area is an asymmetrical structural trough bounded on the west by the Rocky Mountains and on the east by the Great Plains. There has been abundant igneous activity in the area with the Spanish Peaks and Raton Mesa the most prominent remnants. The Vermejo Formation of Late Cretaceous age and the Raton Formation of Late Cretaceous and Paleocene age are the principal coal-bearing formations.

The more than 8,000 feet of topographic relief in Area 61 has a significant impact on the climate and, consequently, on the pattern of stream runoff. Precipitation ranges from less than 16 inches at lower elevations to more than 40 inches on mountain crests. Because a large percentage of the annual runoff comes from snowmelt during spring and early summer months, reservoirs commonly are used to store water in the Plains area where the long-term average annual precipitation is less than 16 inches.

Much of the land in Area 61 is privately owned. Livestock grazing, forest industry, irrigated agriculture, recreation, and mining are the principal land uses. Agriculture is the chief use of water.

Streamflow is gaged at 52 sites. Streams with headwaters above 10,000 feet generally have a better sustained flow than those with drainage basins at lower elevations. Flash floods with high, sharp peaks and short durations are a problem.

Virtually all geologic units in the region yield water to wells. The depth to ground water varies from the land surface to 400 feet. Ground water is both confined and unconfined. The ground-water data base includes 376 sites.

Ground water and surface water in Area 61 contain mostly calcium and sodium bicarbonate and sulfate ions; sodium chloride ions locally occur in the ground water. The $\mathrm{pH}$ ranges from about neutral to slightly alkaline.

Hydrologic problems related to mining activities are erosion and increased sedimentation, local decline in the water table, and degradation of water quality. Erosion and sedimentation are primarily surface-mining problems. Sediment yields increase significantly when vegetation is removed from erodible soils. Disruption of the water table is both a surface- and an underground-mining problem. Degradation of water quality can result from drainage from either surface or underground mines.

All historical and current data related to stream discharge, water quality, sediment, and biology are available from computer storage through the National Water Data Storage and Retrieval System (WATSTORE) and through the National Water Data Exchange (NAWDEX). Current data are published in annual Water Resources Data reports for Colorado and New Mexico. 


\subsection{OBJECTIVE}

\section{Report on Area 61--Raton Mesa Coal Region--Submitted in Support of Public Law 95-87}

\section{Description of existing hydrologic conditions is presented and sources of hydrologic information are identified.}

This report provides hydrologic information using a brief text with an accompanying map, chart, graph, or other illustration for each of a series of topics related to water resources. The summation of topical discussions provides a description of the hydrology of Area 61--Raton Mesa coal region. This information should be useful to mine owners, mine operators, and consulting engineers in the preparation of permit applications and to regulatory authorities in appraising the adequacy of the permits.

A need for hydrologic information and analysis on a National scale was identified when the "Surface Mining Control and Reclamation Act of 1977" was signed into law as Public Law 95-87, on August 3, 1977.

Coal-producing regions in the United States have been divided by the U.S. Geological Survey into hydrologic report areas. These areas are combina- tions or segments of hydrologic units modified to reflect the distribution of the coal. Area 61, delineated in figure 1.0-1, is located north and south of the State boundary between Colorado and New Mexico and encompasses parts of Huerfano and Las Animas Counties in Colorado and Colfax County in New Mexico.

The hydrologic information presented or available through sources identified in this report may be used in describing the hydrology of the general area of any proposed mine. It is expected that this hydrologic information will be supplemented by data from the lease applicant's specific site and from other sources to provide a more detailed appraisal of the hydrology in the vicinity of the mine and of the anticipated hydrologic consequences of the mining operation. 


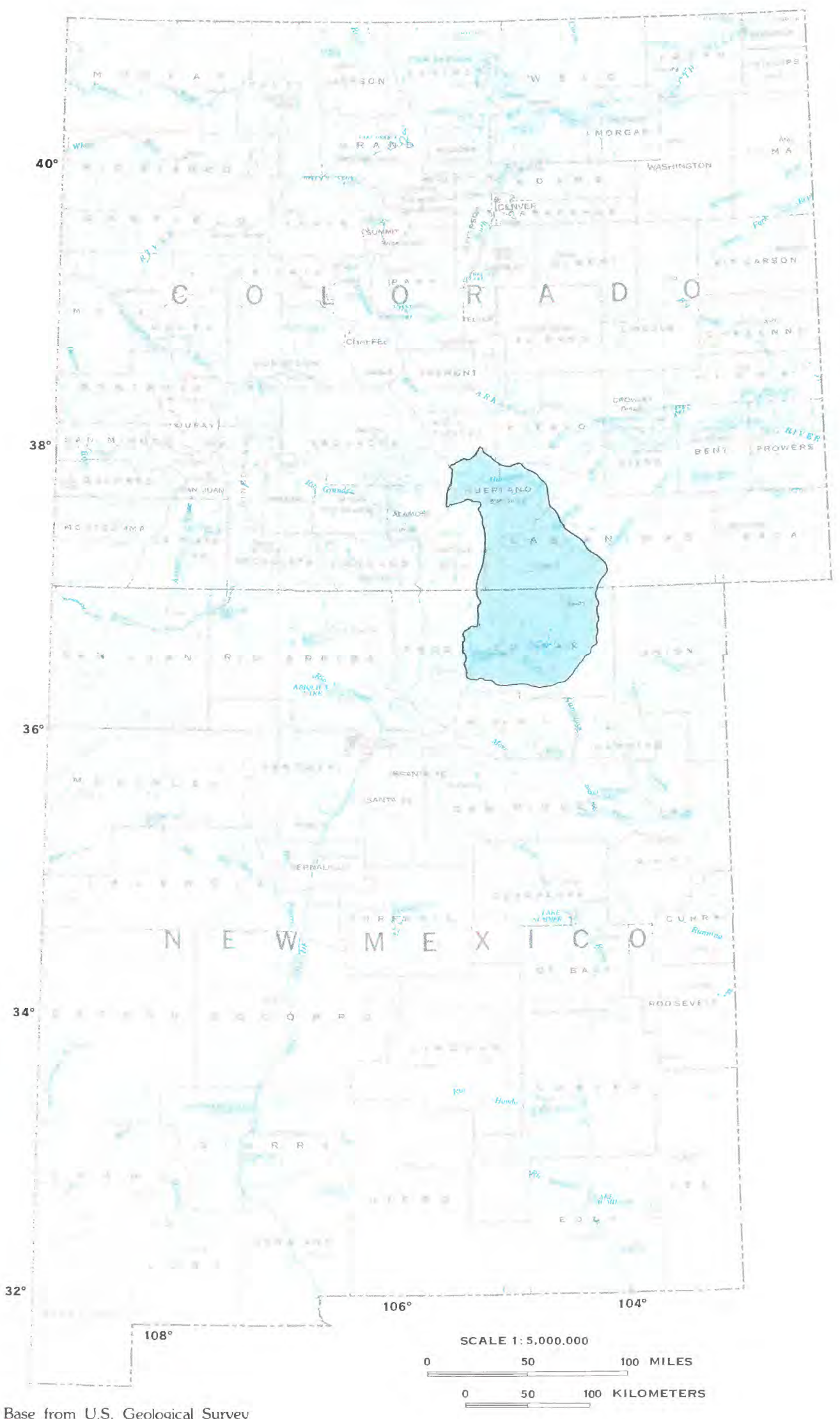

Base from US. Geological Survey

State base maps, 1980.

Figure 1.0-1 Location of Area 61. 


\title{
2.0 GENERAL FEATURES \\ 2.1 Physiography
}

\section{The Raton Basin Is the Principal Physiographic Feature of Area 61}

\author{
Area 61 is part of the Raton section of the Great Plains Province and is \\ bordered on the north by the Wet Mountains, on the west by the \\ Sangre de Cristo Range, and on the east and south by the Las Vegas Plateau.
}

Area 61 lies on the west edge of the Great Plains at the base of the Rocky Mountains. The coal basin proper is a north-trending asymmetrical trough. The eastern limb of the trough has a gentle dip; the western limb dips steeply and is vertical at places. The Trinidad Sandstone below the lowest coal-bearing horizon is a massive sandstone which forms escarpments where it crops out. The surface of the structural trough is a dissected highland known as the Park Plateau (Fenneman, 1931).

The basin is bordered on the north by the Wet Mountains and on the west by that segment of the Sangre de Cristo Range known as the Culebra Range. The Cimarron Range is an eastern spur of the Sangre de Cristo Range in Colfax County, N. Mex. To the south and east is the Las Vegas Plateau. A deep indentation between the Culebra and the Wet Mountain Ranges at the northern end of the area is Huerfano Park and the headwaters of the Huerfano River basin (fig. 2.1-1).

Conspicuous features of igneous origin are located in the area. The most prominent are two stocks named Spanish Peaks which rise to an elevation of more than 13,000 feet. Other igneous mountains include Mount Mestas (La Veta Peak), Rough Mountain, Dike (Silver) Mountain, the Black Hills, Sheep Mountain, and Little Sheep Mountain. Associated with Dike Mountain and the Spanish Peaks are many igneous dikes that, because of differential erosion, form conspicuous wall-like structures radiating from the peaks (fig. 2.1-2).

Raton Mesa is another physiographic feature of igneous origin. Located north and south of the Colorado-New Mexico State boundary along the east edge of the area and extending eastward out of the area, the mesa is the lava-capped remnant of an earlier, higher plain. Fishers Peak near Trinidad, Colo., is an erosional remnant that marks the western extremity of Raton Mesa.

Elevations in the area range from about 5,600 feet at those points where the Purgatoire and the Canadian Rivers flow from the area to 14,345 feet at the top of Blanca Peak. 

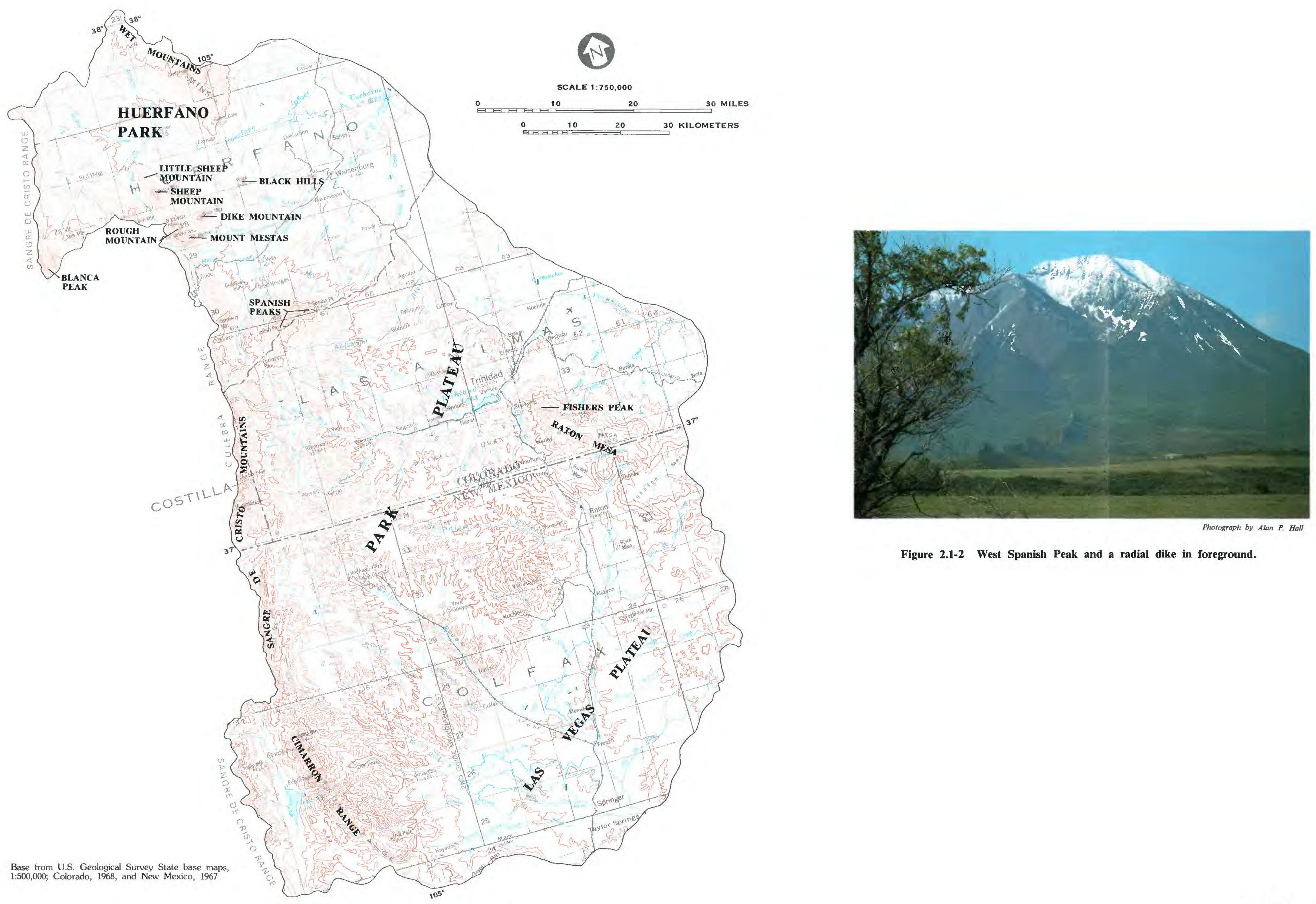

Figure 2.1-2 West Spanish Peak and a radial dike in foreground. 


\title{
2.0 GENERAL FEATURES--Continued \\ 2.2 Drainage
}

\section{Area 61 Is Entirely Within the Arkansas River Drainage Basin}

\author{
The area includes the headwaters of the Huerfano, the Apishapa, the Purgatoire, \\ and the Canadian Rivers and their tributaries, which are all tributary to the \\ Arkansas River.
}

The northern part of the area is drained by the Huerfano River and its principal tributary, the $\mathrm{Cu}$ charas River. The drainage area within Area 61 is 1,460 square miles, of which 660 square miles is the Cucharas basin. The Apishapa River, a primary tributary to the Arkansas River, drains 320 square miles of the area between the Huerfano River basin and the Purgatoire River basin to the south. The Purgatoire River, also known as the Las Animas River, drains 1,340 square miles of the area just north of the Colorado-New Mexico State boundary.

That part of the area south of the State boundary in New Mexico is drained by the Canadian River and its principal tributaries, the Vermejo and the Cimarron Rivers. The drainage area of the Canadian River system within the study area is 2,780 square miles.

The basin boundaries of the principal streams in Area 61 are shown in figure 2.2-1. Also shown in figure 2.2-1 are the boundaries of the water districts designated by Colorado for administrative purposes.

Colorado is divided into seven water divisions; Water Division No. 2, headquartered in Pueblo, is responsible for the Arkansas River basin. Each water division is further subdivided into water districts that are administered by a water commissioner. The headwaters of the Huerfano River are in Water District 79. The Cucharas River is in Water District 16. The Apishapa River is in Water District 18, and that part of the Purgatoire River drainage in Area 61 is in Water District 19. New Mexico is divided into three water districts under the administration of the New Mexico State Engineer. The northeastern part of the State, however, which includes the Canadian River basin, is not in any of the three districts and is administered directly by the Water Rights Bureau of the State Engineer's Office. 


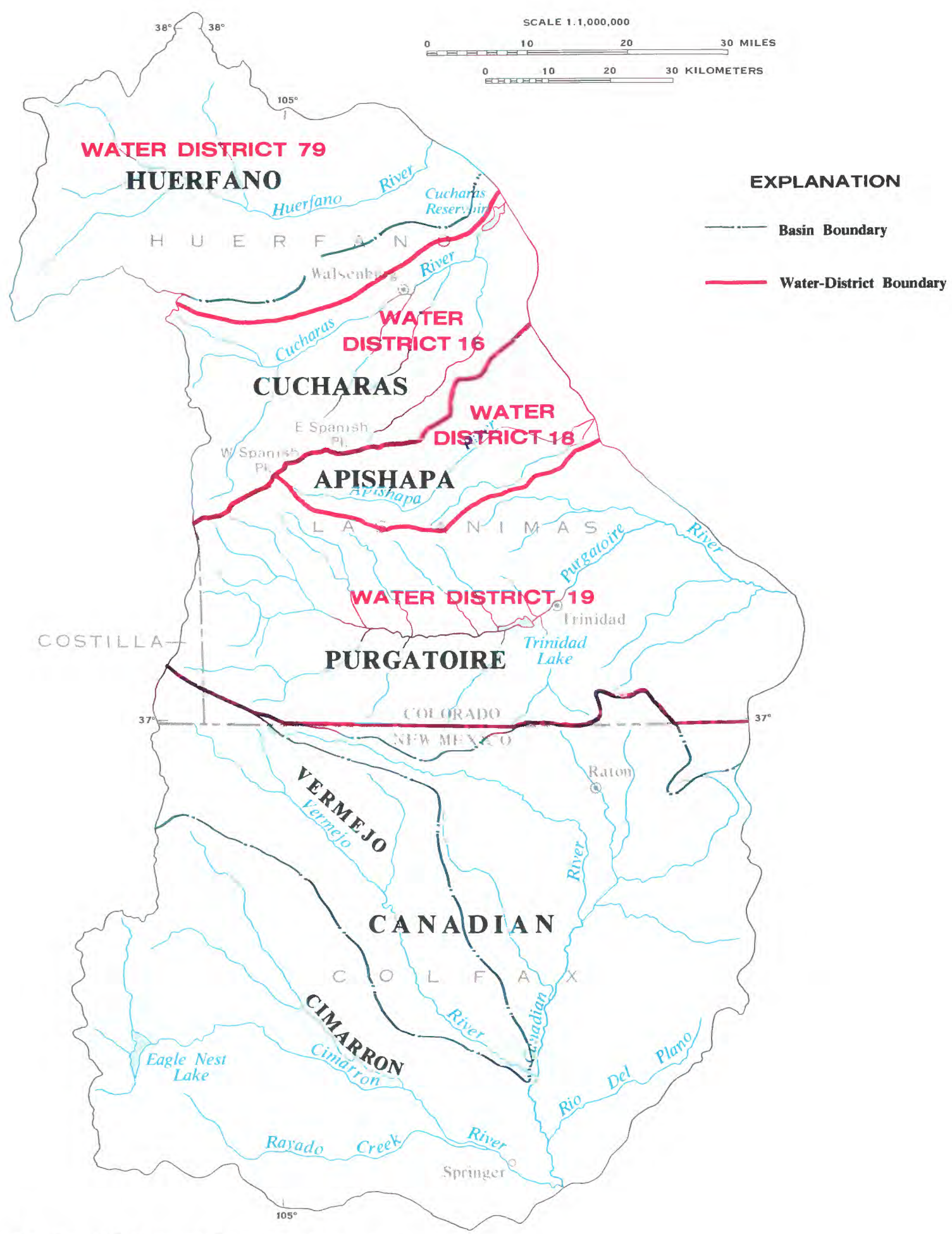

Base from U.S. Geological Survey State base maps,

1:500,000; Colorado, 1968, and New Mexico, 1967

Figure 2.2-1 Drainage basins and Colorado Water Districts. 


\subsection{GENERAL FEATURES--Continued 2.3 Soils}

\section{Soils Vary With Topography}

\section{Soils in Area 61 vary with terrain, differing in the mountains, foothills, plains, and river valleys.}

Dominant orders of soils in Area 61 as classified by the U.S. Comprehensive Soil Classification System are shown in figure 2.3-1. The soils vary with topography and differ in the mountains, foothills, plains, and river valleys. The orders can be subdivided into suborders, great groups, and subgroups.

The following describes the orders in Area 61:

Alfisols, found mostly in the forested mountains and wooded foothills, are gray to brown soils that are usually moist but may be dry during the warm season. They are acid soils, slow to moderately permeable ( 0.06 to 2.0 inches per hour), and range from 20 to 60 inches in depth.

Aridisols, found chiefly in the foothills, are layered soils characteristic of arid regions. Locally the soils are alkaline and have permeabilities ranging from slow ( 0.06 inch per hour) to rapid (20.0 inches per hour). Depth generally ranges from 20 to 60 inches.

Entisols, found on the plains, have no layering. They are alkaline soils of moderate permeability $(0.6$ to 2.0 inches per hour) and generally range in depth from 20 to 60 inches.

Inceptisols in Area 61 are found above timberline and are formed quickly by alteration of parent material. They are acid soils with permeabilities ranging from 0.2 to 6.0 inches per hour. Depths generally range from 20 to 40 inches.

Mollisols, locally associated with igneous bedrock, such as the Raton Mesa lava flows, are soils having nearly black organic-rich surfaces. They are alkaline soils with permeabilities ranging from 0.2 to 6.0 inches per hour. Depths generally range from 20 to 60 inches.

In general, the soils of Area 61 are well drained. Erosion potential varies widely. Increased erosion commonly results from removal of vegetation by fire, overgrazing, surface mining, or road construction.

A general soils map is available for New Mexico (U.S. Soil Conservation Service, 1974) and for Colorado (Heil and others, 1977). General soils maps are available for each of the three counties in the area--Huerfano, Las Animas, and Colfax Counties--from the U.S. Soil Conservation Service. The U.S. Soil Conservation Service is currently (1982) preparing detailed soils maps on aerial photograph bases for parts of Area 61 . 


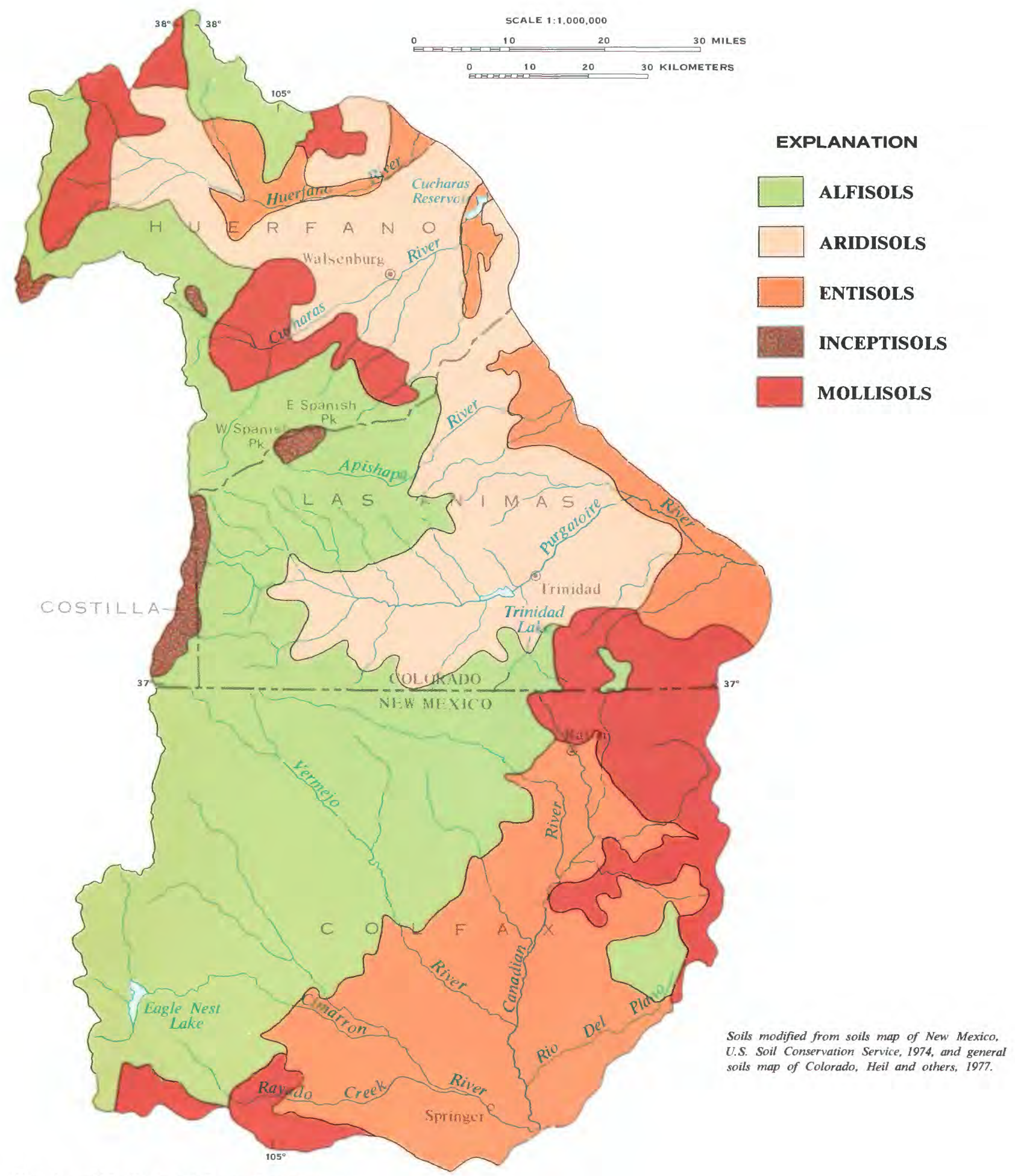

Base from U.S. Geological Survey State base maps,

1:500,000; Colorado, 1968, and New Mexico, 1967

Figure 2.3-1 Soils. 


\title{
2.0 GENERAL FEATURES--Continued 2.4 Geology \\ 2.4.1 Stratigraphy
}

\section{Precambrian To Quaternary Rocks Underlie Area}

\author{
Sedimentary rocks in the area record the presence of Pennsylvanian \\ and Cretaceous seas and intervening episodes of land emergence.
}

The oldest rocks in the area are Precambrian granite, pegmatite, gneiss, schist, and quartzite (Johnson, 1969). These crystalline rocks form the core of the Sangre de Cristo Range and the Wet Mountains (fig. 2.4.1-1).

Paleozoic and Mesozoic formations flank the mountains and extend beneath the rest of the area (Griggs and Northrop, 1956; Oriel and Mudge, 1956; Shaw, 1956). The rocks consist of marine limestone, shale, and sandstone of the Pennsylvanian Minturn and Belden Formations in Colorado and the Magdalena Group in New Mexico overlain by terrestrial sediments of the Pennsylvanian to Jurassic Sangre de Cristo Formation, Yeso Formation, Lyons (Glorietta) Sandstone, Dockum Group, Entrada Sandstone, Ralston Creek (Wanakah) Formations, and Morrison Formation. The Sangre de Cristo Formation and Dockum Group wedge out northeastward across the area as the Yeso Formation and Lyons Sandstone thicken. The aggregate thickness of Paleozoic and Mesozoic rocks decreases from more than 10,000 feet $(\mathrm{ft})$ in the Sangre de Cristo Range to a few hundred feet in the northeastern corner of the area.

Deposits of a Cretaceous sea border the west side of the Park Plateau and extend beneath it to the eastern edge of the area (Griggs, 1948, p. 22-34; Cobban, 1956; Wood and others, 1957, p. 17-22). The Purgatoire Formation (Cheyenne Sandstone and Kiowa Shale Members) and Dakota Sandstone, which together average about $200 \mathrm{ft}$ thick, mark the advance of the sea. They are overlain by the Graneros Shale, Greenhorn Limestone, Carlile Shale, Niobrara Formation (Fort Hays Limestone and Smoky Hill Marl Members), and Pierre Shale. These formations contain more than 3,000 ft of shale and interbedded sandstone and limestone. A shoreline deposit intertonguing with the top of the Pierre Shale, the Trinidad Sandstone ( 0 to $310 \mathrm{ft}$ thick), marks the retreat of the sea near the end of the period.

In the Park Plateau, a transition from marine to coastal plain to terrestrial sediments records the rise of the Rocky Mountains (Johnson and Wood, 1956). At the base of this sequence, the Vermejo Formation, a Cretaceous coastal plain deposit as much as $550 \mathrm{ft}$ thick, intertongues with the Trinidad Sandstone. The Vermejo Formation consists of carbonaceous and silty shale with lenses of coal and sandstone. It is unconformably overlain by the Raton Formation, a Cretaceous and Paleocene coastal plain deposit as much as $2,000 \mathrm{ft}$ thick. The middle of the Raton Formation resembles the Vermejo, but the upper and lower several hundred feet of the Raton Formation are predominantly sandstone, siltstone, and noncarbonaceous shale. On the northern and southern edges of the plateau, the Poison Canyon Formation intertongues with and overlaps the Raton Formation. The Poison Canyon Formation, which consists of $2,500 \mathrm{ft}$ of sandstone, conglomerate, and shale, is mostly Paleocene. Where the lower part of the formation intertongues with the Raton Formation in the western part of the area, it is Cretaceous. The Cuchara, Huerfano, Farasita, Devils Hole, and Santa Fe Formations of Eocene to Pliocene age overlie the Poison Canyon Formation and consist of conglomerate, sandstone, shale, and volcanic tuff as much as $10,000 \mathrm{ft}$ thick. These formations, and the Poison Canyon Formation, were formed mostly by erosion of the rising mountains.

Recently deposited clay to boulder-sized alluvium as much as $50 \mathrm{ft}$ thick occurs in stream channels, terraces, and pediments. Landslides, eolian deposits, and talus also are present (Griggs, 1948, p. 65-70; Powell, 1952).

Stocks, laccoliths, plugs, dikes, and sills ranging in composition from granite to diabase and lamprophyre intrude the sedimentary rocks and form prominent landmarks such as the Spanish Peaks, Black Hills, Mount Mestas, and Cimarron Range (Johnson, 1968). Along the southern and southeastern edges of the basin, basalt flows cap uplands such as Raton Mesa and Eagle Tail Mountain (Griggs, 1948, p. 38-40). 


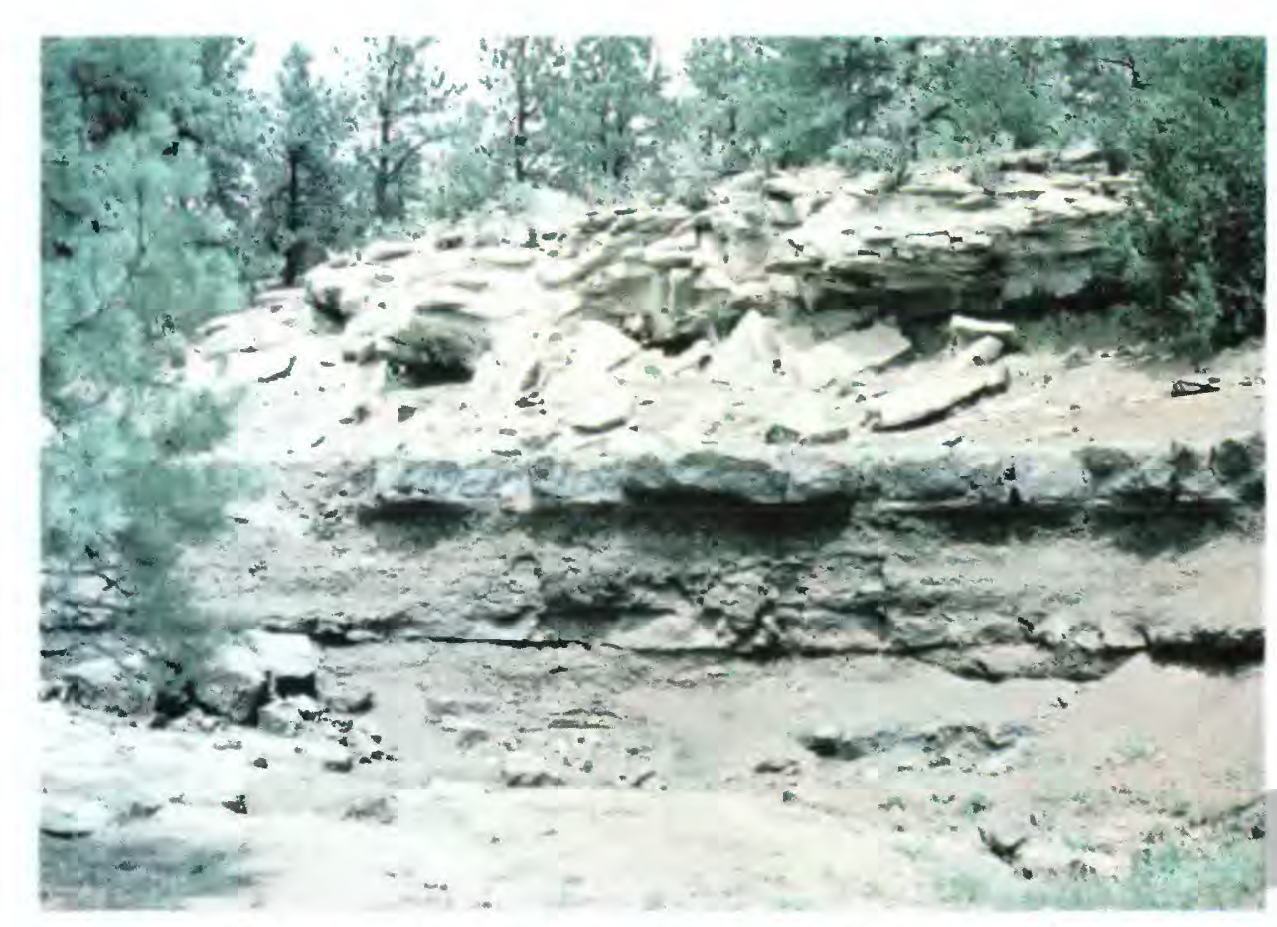

Poison Canyon Formation overlying upper Raton Formation.

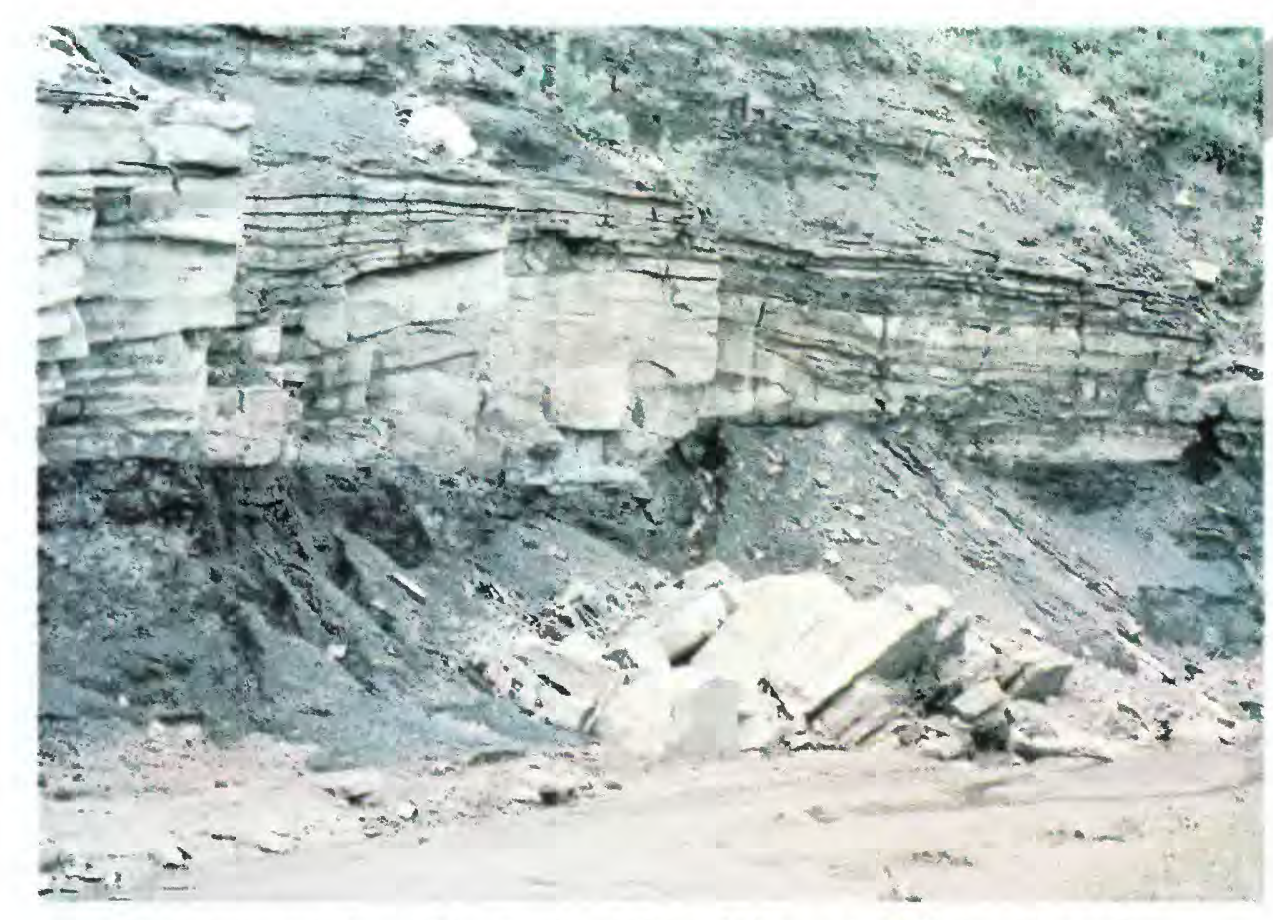

Sandstone lens in carbonaceous shale, middle part of Raton Formation
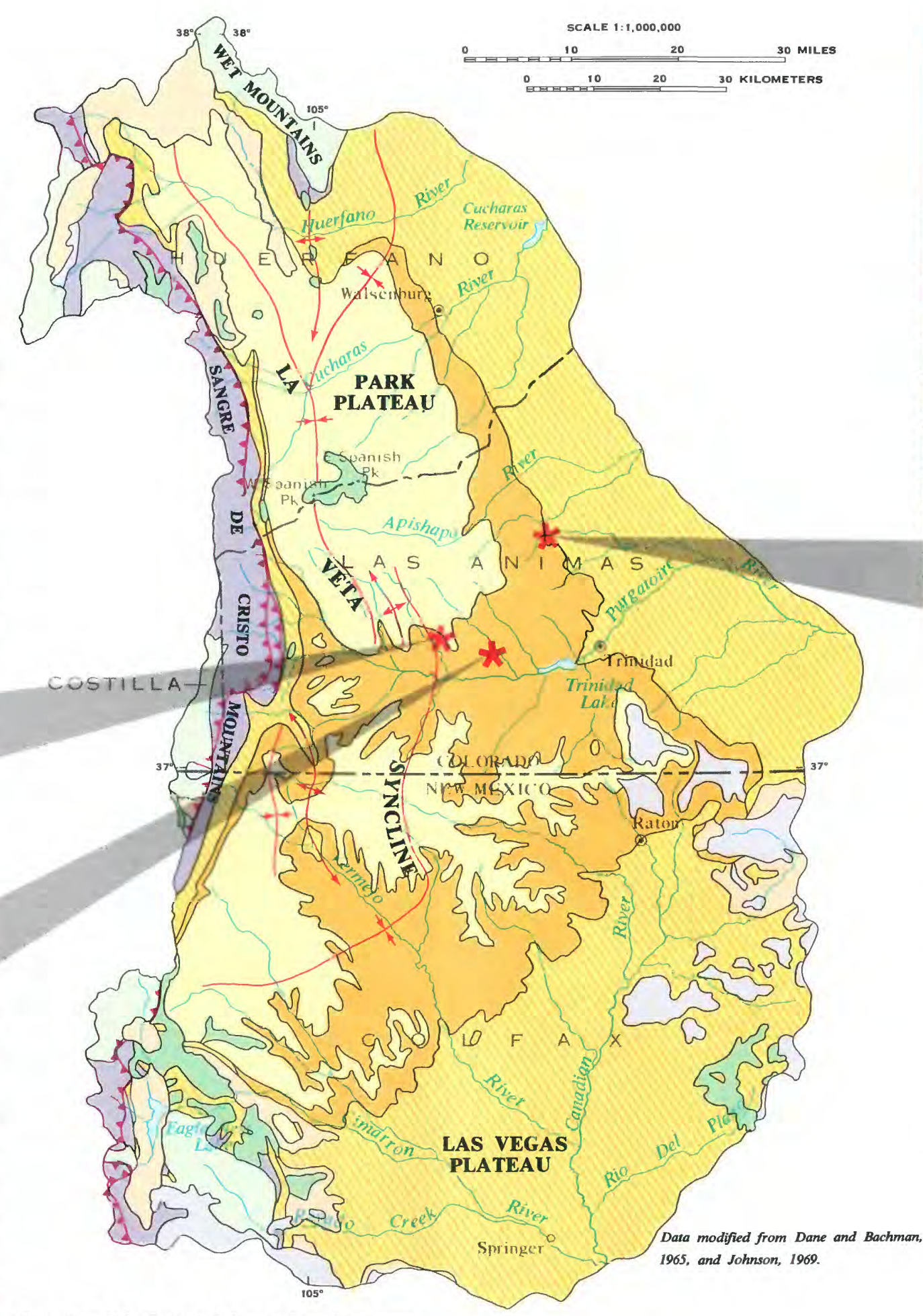

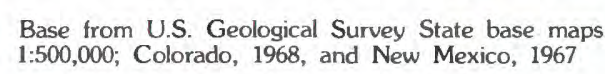

Figure 2.4.1-1 Geology.

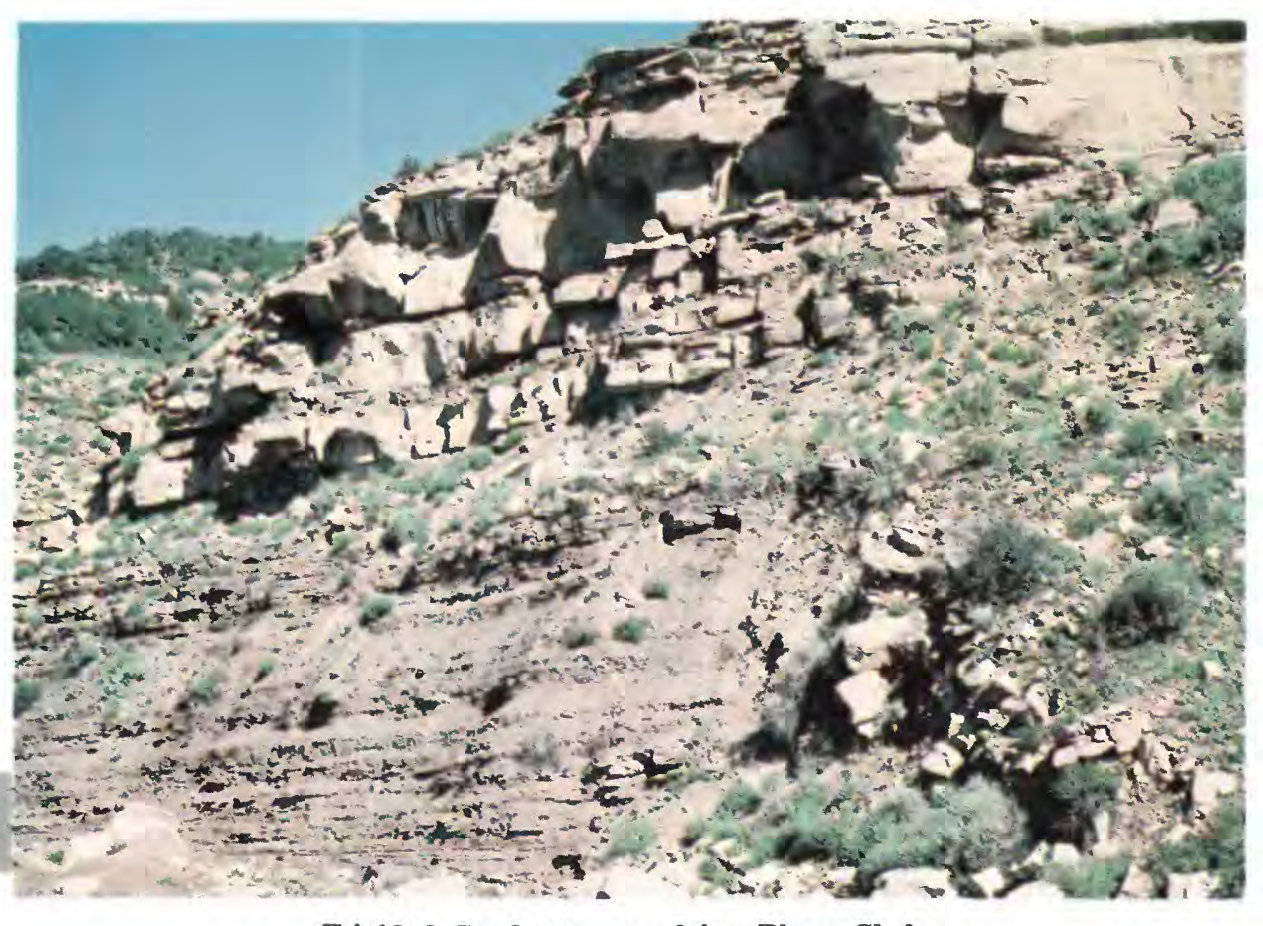
Trinidad Sandstone, overlying Pierre Shale.

\begin{tabular}{|c|c|c|c|}
\hline & EXPLANATION & & \\
\hline AGE & FORMATION & $\underset{\text { (in feet) }}{\text { THICKNSS }}$ & MAP UNIT \\
\hline Holocene & $\begin{array}{l}\text { Alluwium, landslide deposits } \\
\text { and talus }\end{array}$ & & \\
\hline Pliocene-Miocene & Santa Fe Formation & & \\
\hline $\begin{array}{l}\text { Miocene } \\
\text { Oliocone }\end{array}$ & Devils Hole Formation & $0-1300$ & \\
\hline Quaternary and Tertiary & Volcanic rocks & & $\square$ \\
\hline Tertiary & Intrusive rocks & & $\square$ \\
\hline Eocene & Huerfano Formation & $0-2000$ & \\
\hline Paleocene & $\begin{array}{l}\text { Cuchara Formation } \\
\text { Poison Canyon Formation }\end{array}$ & $\begin{array}{l}0.50000 \\
0-2500\end{array}-10$ & \\
\hline Paleocene-Cretaceous & Raton Formation & $0-2000$ & \\
\hline Cretaceous & $\begin{array}{l}\text { Vermejo Formation } \\
\text { Trinidad Sandstone }\end{array}$ & $\begin{array}{l}0.550 \\
0.310\end{array}$ & \\
\hline Cretaceous & $\begin{array}{l}\text { Pierre Shale } \\
\text { Niobrara Formation } \\
\text { Carrilie Shale, Greenhorn } \\
\text { Limestone, Graneros Shale }\end{array}$ & $\begin{array}{l}0-2300 \\
0-950 \\
0-530\end{array}$ & \\
\hline & $\begin{array}{l}\text { Dakota Sandstone } \\
\text { Purgatoire Formation }\end{array}$ & $\begin{array}{l}50-200 \\
60-160\end{array}$ & \\
\hline Jurassic & $\begin{array}{l}\text { Morrison and Ralston Creek } \\
\text { (Wranakath) Formations }\end{array}$ & $260-415$ & \\
\hline & Entrada Sandstone & $30-75$ & \\
\hline Triassic & Dockum Group & $0-1000$ & \\
\hline Permian & $\begin{array}{l}\text { Lyons (Glorietta) Sandstone } \\
\text { Yeso Formation }\end{array}$ & $\begin{array}{l}0 .-325 \\
0.240\end{array}$ & \\
\hline Pennsylvanian-Permian & Sangre de Cristo Formation & $200-10,000$ & \\
\hline Pennsylvanian & $\begin{array}{l}\text { Minturn and Belden Formations } \\
\text { Magdalena Group }\end{array}$ & $0-8500$ & \\
\hline Precambrian & Igneous and Metamorphic rocks & & 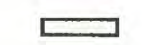 \\
\hline
\end{tabular}

THRUST FAULT $\stackrel{t}{\uparrow}$ SYNCLINE $\longrightarrow$ PLUNGING ANTICLINE

2.0 GENERAL FEATURES--Continued 2.4.1 Stratigraphy 


\title{
2.0 GENERAL FEATURES--Continued \\ 2.4 Geology--Continued \\ 2.4.2 Structure
}

\section{The Principal Structure Is an Asymmetrical Trough}

\author{
The trough, centered north of the Spanish Peaks, dips gently on the east limb, \\ steeply on the west limb, and is modified locally by anticlines, synclines, \\ and faults.
}

The principal structure in Area 61 is an asymmetrical trough (Gabelman, 1956; Amuedo and Ivey, 1974, pl. 13). The axis of the trough, the La Veta Syncline (fig. 2.4.2-1), extends southeastward from Huerfano Park to Wet Canyon, where it is interrupted by a plunging anticline and shifted eastward to Sarcillo Canyon. From Sarcillo Canyon, the synclinal axis continues southward into New Mexico. Near the Vermejo River, it turns west-southwest and extends to the headwaters of the Cimarron River.

The trough is centered north of the Spanish Peaks, as indicated by structure contours on top of the Trinidad Sandstone (fig. 2.4.2-1). The east limb dips generally less than $5^{\circ}$ from the Apishapa, Las Animas, and Sierra Grande arches, on the east side of the basin (fig. 2.4.2-2). The west limb becomes vertical to overturned on the western flank of the basin within a relatively short distance of the synclinal axis (fig. 2.4.2-3). About 16,000 feet of sedimentary rocks overlie Precambrian basement in the center of the trough.

Folds and faults modify the regional structure. The Delcarbon syncline joins the La Veta syncline in the northern part of the area. Between the two, the Wet Mountains uplift plunges beneath the surface and becomes the Greenhorn anticline. The Vermejo and Tercio anticlines, straddling the Colorado-New Mexico State boundary, form an anticlinorium that brings Pierre Shale to the surface through a cover of Trinidad, Vermejo, Raton, and Poison Canyon rocks. The Pierre Shale also is exposed in the center of the Morley Dome, south of Trinidad, Colo. Folds with small amplitude occur throughout the area. In the northwestern corner, complexly arranged folds and thrust faults affect formations ranging from Pennsylvanian to Paleocene in age. Thrust faults in the Sangre de Cristo Range along the western edge of the area bring Precambrian crystalline rocks into contact with younger Paleozoic and Mesozoic sedimentary rocks. Normal faults with small displacement affect the Raton and Poison Canyon Formations in the Park Plateau and Cretaceous marine strata in the Las Vegas Plateau.

The Black Hills laccolith domes the sedimentary rock it intrudes. A block of very fractured and faulted metamorphic rocks between East and West Spanish Peaks was emplaced during intrusion of the Spanish Peaks stocks. Numerous other stocks, such as Mount Mestas, invaded the sedimentary rocks without structural disruption. 

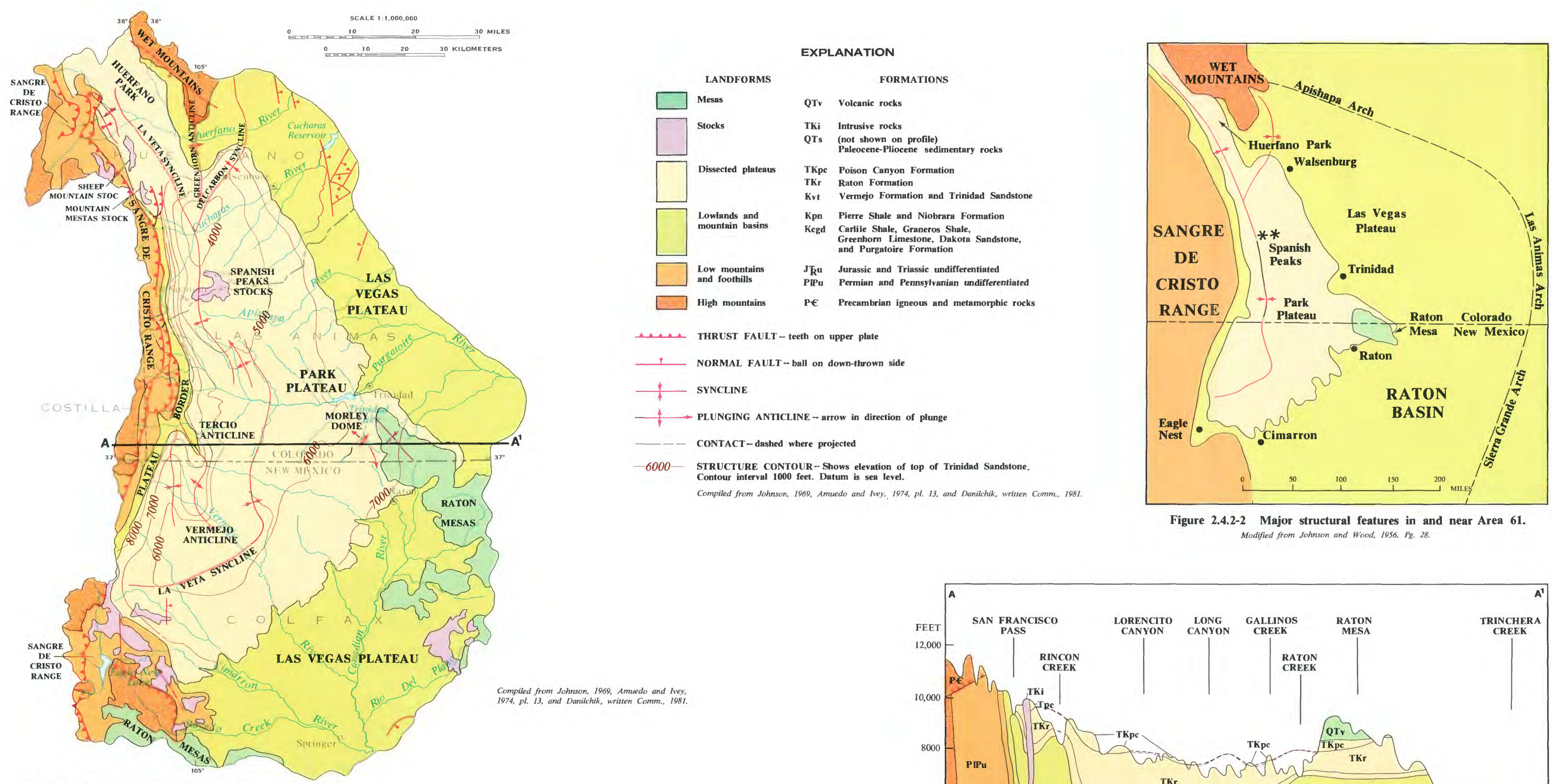

Figure 2.4.2-2 Major structural features in and near Area 61. Compiled from Johnson, 1969, Amuedo and Ivey, 1974, pl. 13. and Danilchil, written Comm, 1981 Modified from Johnson and Wood, 1956. Pg. 28.

Base from US. Geelogical Survey State base mans
1.500,000; Colorardo, 1968 , and New Mexico, 1967

Figure 2.4.2-1 Geologic structure.

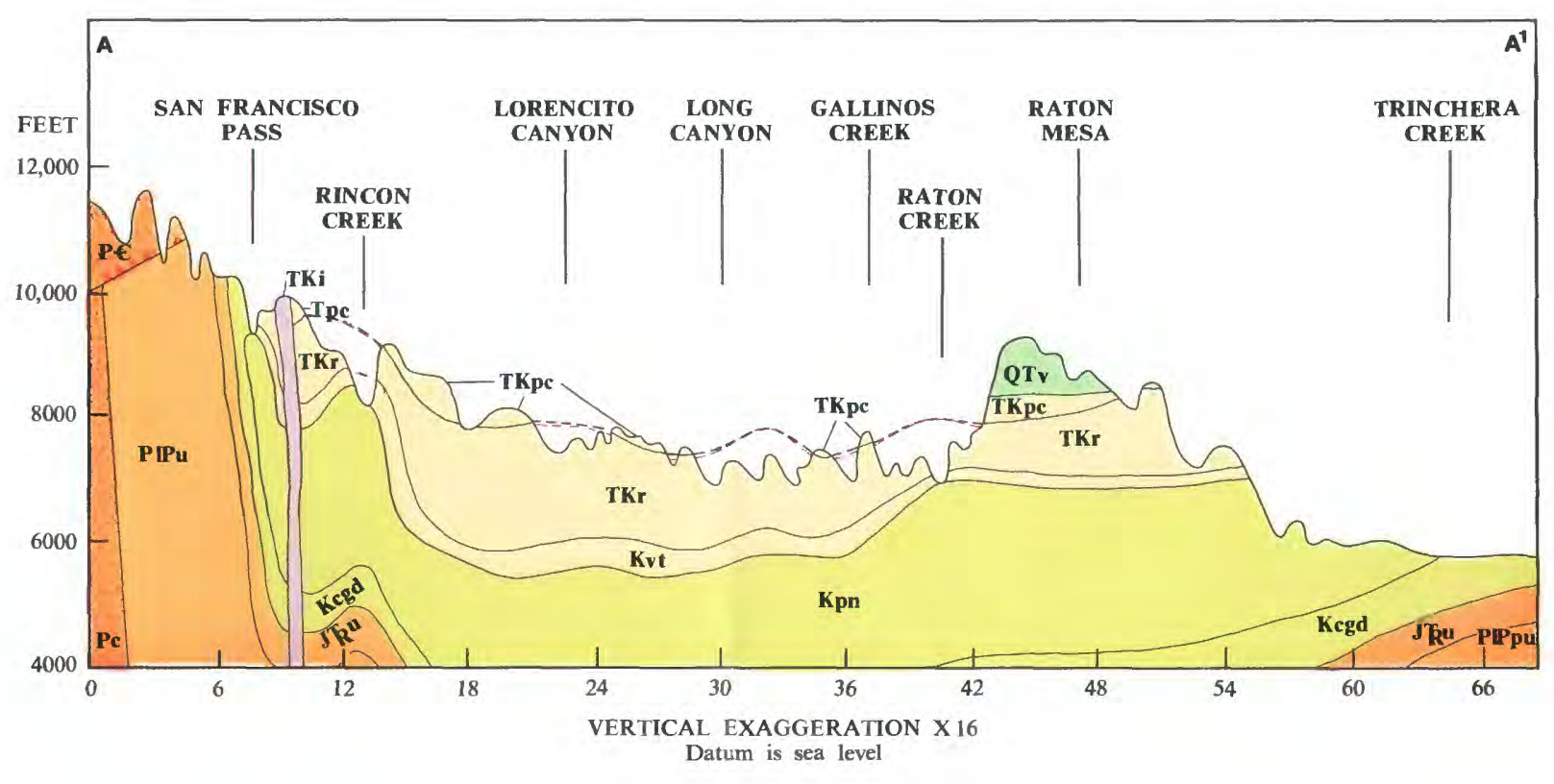

Figure 2.4.2-3 Structural profile. 


\title{
2.0 GENERAL FEATURES--Continued $2.5 \mathrm{Coal}$ \\ 2.5.1 Mineral Resources--Coal
}

\section{Area 61 Encompasses the Raton Mesa Coal Region, Which Includes the Raton, Trinidad, and Walsenburg Coal Fields}

\author{
Much of the coal from the Raton Mesa coal region is of coking quality.
}

The Raton Mesa coal region (fig. 2.5.1-1) has an area of 2,140 square miles (Carter, 1956). The 986-square-mile area in New Mexico is known as the Raton coal field; the 1,154 square miles in Colorado is known as the Trinidad coal field. The Trinidad coal field is considered by some investigators to be two fields--the Trinidad and the Walsenburg.

The presence of commercial quantities of coal in the area has been known since as early as 1821 (Lee and Knowlton, 1917), but mining was not begun until about 1873 (Harbour and Dixon, 1959). Mining activity reached a climax between 1900 and 1930 (Johnson, 1961).

Coal from the Walsenburg coal field generally is high-volatile $\mathrm{B}$ and $\mathrm{C}$ bituminous of noncoking quality. Coal from the Trinidad and Raton coal fields generally is high-volatile $\mathrm{A}$ and $\mathrm{B}$ bituminous of coking quality (Nielsen, 1979). The coal in the Raton field is classified high-volatile C bituminous (Wanek, 1963).

Production from the Raton Mesa coal region through 1975 was 325.5 million short tons, of which
247.5 million short tons were produced in Colorado and 78 million short tons were produced in New Mexico (Amuedo and Bryson, 1977). Reserves with thickness equal to or exceeding 28 inches at depths less than 3,000 feet in New Mexico have been estimated at about 3.3 billion short tons (Berryhill and Averitt, 1951); the total remaining reserves in the Trinidad and Walsenburg coal fields--the Colorado part of the region--are estimated at 8 billion short tons, for a total remaining reserve of about 11.3 billion short tons.

In 1978 the following coal mines were licensed in the Raton Mesa coal region in Colorado: Allen, Maxwell, Delagua Strip (old Berwind), Healey Strip, and Jewell Strip. The Allen and Maxwell are underground mines operated by CF\&I Steel Corp. The Healey Strip and Jewell Strip are surface mines operated by the Delagua Coal Co. Calument No. 2, a surface mine operated by the Delagua Coal Co., was nearing production (Dawson and Murray, 1978). In New Mexico, the Kaiser Steel Corp. operates a strip and underground mine in York Canyon (Nielsen, 1980). 


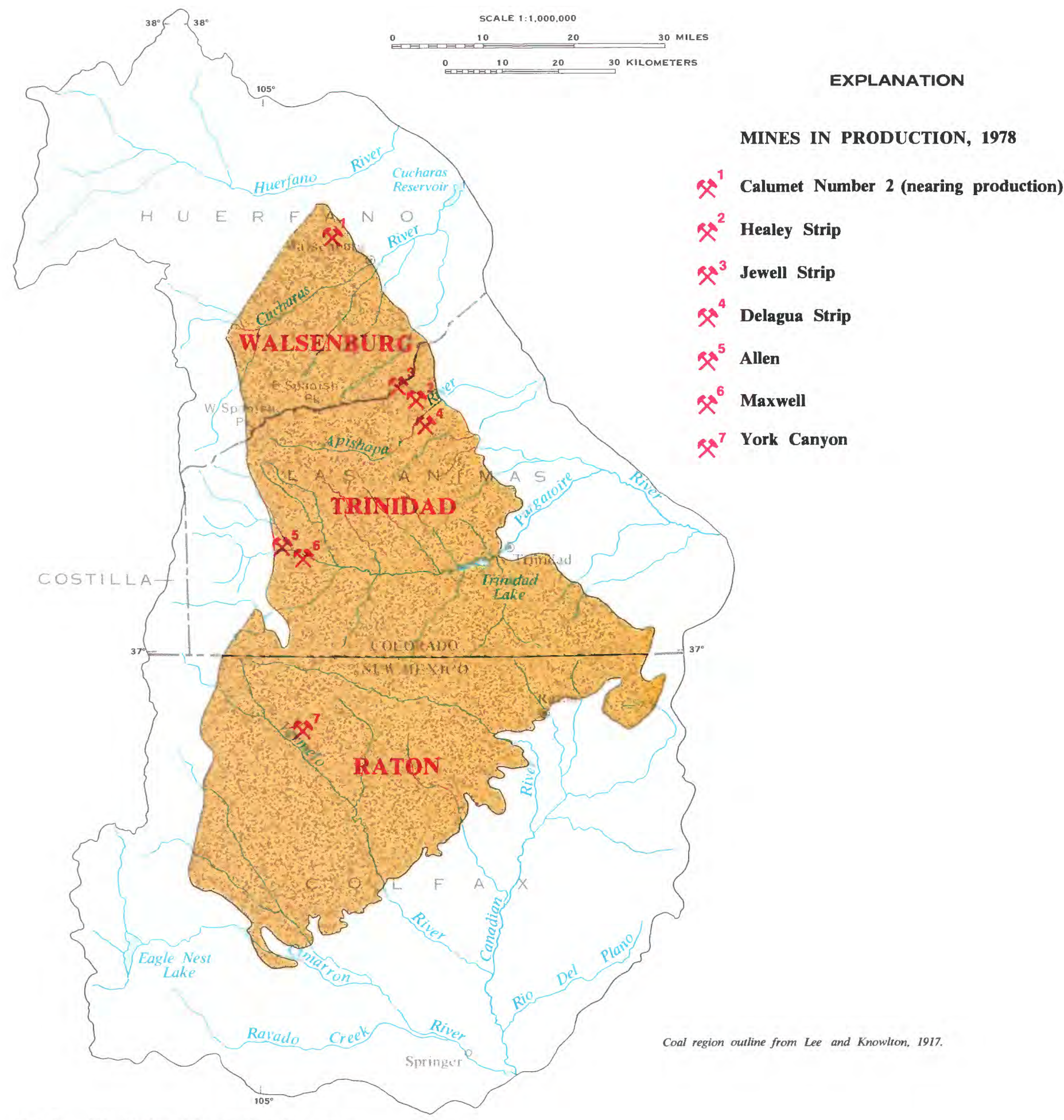

Base from U.S. Geological Survey State base maps,

1:500,000; Colorado, 1968, and New Mexico, 1967

Figure 2.5.1-1 Raton Mesa coal region, coal fields, and producing mines. 


\title{
2.0 GENERAL FEATURES--Continued \\ 2.5 Coal--Continued \\ 2.5.2 Coal Stratigraphy
}

\section{The Vermejo and Raton Formations Contain Commercial Deposits of Bituminous Coal}

\author{
Coal beds of the Vermejo Formation are thicker and more persistent \\ than those of the Raton Formation.
}

The Vermejo and Raton Formations contain commercial deposits of bituminous coal that underlie approximately 1,760 square miles of Area 61 (fig. 2.5.2-1). These deposits are at or near the surface on the edges of the Park Plateau and in the drainages of the Purgatoire, the Canadian, and the Vermejo Rivers, but are more than 3,000 feet deep near the Spanish Peaks. The shallowest deposits of coal 3 feet or more thick are accessible by strip mining (fig. 2.5.2-1).

The Vermejo Formation contains as many as 14 coal beds more than 14 inches thick, and the Raton Formation, as many as 33 coal beds more than 14 inches thick (Johnson, 1961, p. 154-155). The number of beds increases towards the center of the area as the coal-bearing formations thicken from 0 to 2,600 feet. Coal beds in the Vermejo Formation are generally thicker, more persistent, more regular in thickness, and less widely spaced than those in the Raton Formation. Individual beds in the Vermejo Formation obtain a maximum thickness of more than 15 feet, whereas those in the Raton Formation are no more than 10 feet thick (Amuedo and Ivey, 1974, pl. 2-12).

Due to the lenticularity of the coal beds, which resulted from deposition in transitional coastal plain and stream environments, the stratigraphic correlation of coal beds from mine to mine is difficult. Because individual coal beds may thicken, split, or entirely disappear within a distance of less than a mile, more than one mine has assigned two different names to the same coal bed or the same name to two different beds. A generalized stratigraphic correlation of coal beds developed by Boreck and Murray $(1979$, p. $49-50)$ is shown in figure 2.5.2-2. A stratigraphic correlation by Amuedo and Ivey (1974) is similar, but some coal beds are placed in different zones, and the vertical arrangement of some zones is reversed.

The coal in both formations is similar in appearance (fig. 2.5.2-3). It generally is bright and glassy, but may contain beds of charcoal-like material. It may be either compact and hard or brittle and crumbly. It generally has well-developed rectangular fractures, but locally it breaks into rounded masses. Impurities such as sulfur and pyrite (iron sulfide) generally are sparse. Where sills have intruded the coal beds, the coal may be altered to natural coke (fig. 2.5.2-4). North of the Spanish Peaks the coal generally is high-volatile $\mathrm{C}$ bituminous, steam-grade, whereas south of the peaks, it generally is high-volatile $\mathrm{A}, \mathrm{B}$, and $\mathrm{C}$ bituminous coking grade. 

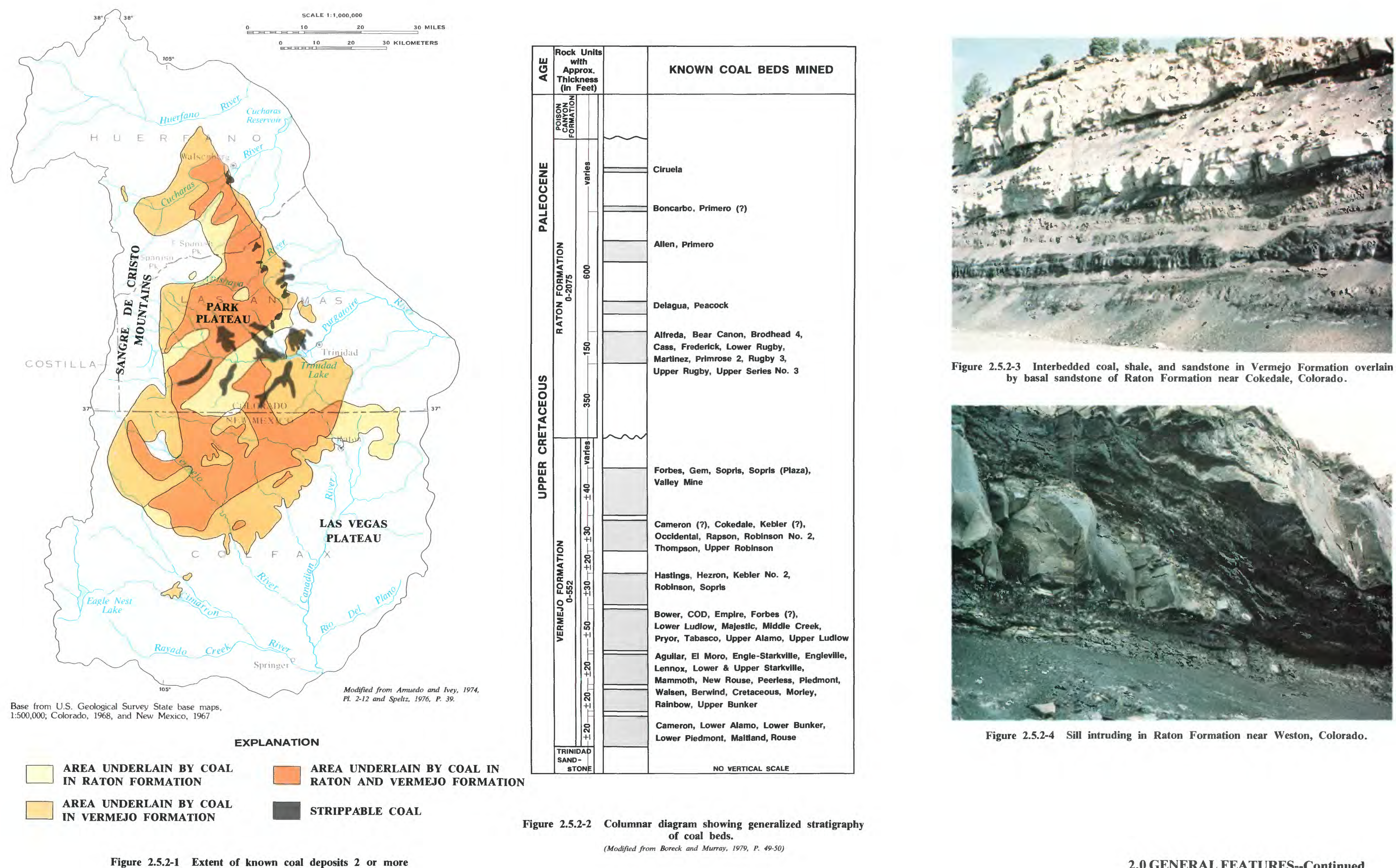
Figure 2.5.2-3 Interbedded coal, shale, and sandstone in Vermejo Formation overlain

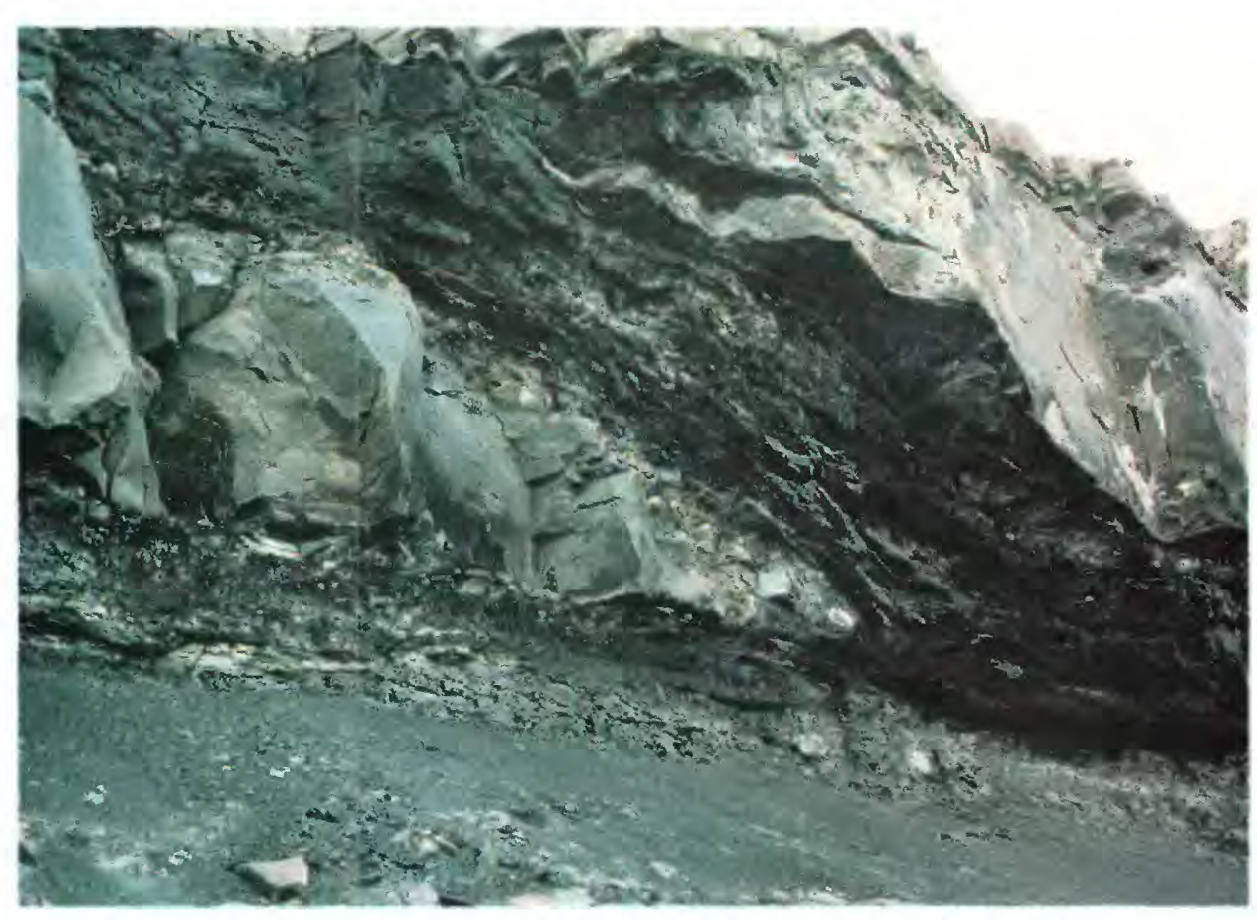

Figure 2.5.2-4 Sill intruding in Raton Formation near Weston, Colorado.

gigure 25.2-1 Extent of known coal deposits 2 or more of coal beds.
(Modififed from Boreck and Murray, 1979, P. 49-50) 


\title{
2.0 GENERAL FEATURES--Continued \\ Mining Reduces Water Supplies to Wells and Slightly Alters Ground- and Surface-Water Quality
}

\author{
Mining lowers ground-water levels, adds dissolved solids to ground and surface \\ water, and increases sediment yields to rivers.
}

Mine shafts discharge more ground water than smalldiameter wells completed in the coal-bearing Raton and Vermejo Formations by exposing a greater surface area of permeable coal and sandstone. Wells compieted in the coal-bearing formations typically yield less than 25 gallons per minute. In contrast, the Maxwell Mine (site 31, fig. 2.5.3-1) is expected to yield 180 gallons per minute when fully developed, and the nearby Allen yields 73 gallons per minute (Water, Waste, and Land, Ltd., 1980, p. 30-31). McLaughlin $(1966$, p. 35) indicates that mines in Huerfano County that are no longer active required pumping rates of 50 to 125 gallons per minute to keep the shafts free of water.

Prolonged pumping of significant quantities of water during mining tends to lower ground-water levels. As shown in figure 2.5.3-2, the ground-water level in 1980 was 240 feet lower at the Maxwell Mine than in an observation well (well 30) 3,000 feet away. Because the water table tends to parallel the topographic surface, the water level at the Maxwell Mine was probably at least 240 feet higher prior to the start of mining. The drawdown of the water table in this mine is expected by the mine owners to extend outward about 3 miles when the mine reaches full production (Water, Waste, and Land, Ltd., 1980, p. 2). Shallow wells near operating mines, like the Maxwell, may go dry as the water table declines. After mining ceases, recovery of the water table will take many years and probably will not reach premining levels because the sloping mine shafts will act as permanent conduits for the ground water. However, the flooded shafts can be expected to yield larger quantities of water to wells than unexcavated bedrock.

Mining operations have a small impact on surfacewater flow in the area. Little surface water is diverted to the few currently operating mines, and since all perennial stream water is allocated, diversion for additional mines is unlikely unless prior water rights are purchased. Discharge from mines into surface drainages is presently small, but will likely increase if mining activity expands. The abandoned Frederick Mine near Trinidad, Colo., discharges 30 to 40 gallons per minute directly into the Purgatoire River. Most abandoned mines are sealed with tailings, and observed discharge through the tailings at individual mines is less than 0.1 gallon per minute. Most of the water pumped from operating mines, such as the Maxwell and York
Canyon Mines, discharges into sump ponds which drain into the Purgatoire and the Vermejo Rivers. The east portal of the Allen Mine discharges 2 to several hundred gallons per minute each day into the Purgatoire River.

Water discharging from mines is more mineralized than in nearby bedrock. As shown in figure 2.5.3-3, water discharging from the Maxwell and Jacks Mines (site 25, fig. 2.5.3-1) contains more dissolved solids than ground water from nearby wells completed in the Raton Formation. In many areas, oxidation of pyrite and other sulfide minerals in coal tailings produces acid mine drainage. In the area, the $\mathrm{pH}$ of water from mines and tailings is 7.0 to 9.2 , generally in the same range as water in bedrock, although the sulfate concentration is notably greater in water from mining activity. Because the coal-bearing formations have little permeability (U.S. Army Corps of Engineers, written commun., 1951; Kaiser Steel Corp., written commun., 1981), plumes of excessively mineralized water from mines and tailings will likely move very slowly into bedrock and alluvium

In contrast, discharges from the Maxwell and Allen Mines consistently add small quantities (less than 10 percent) of calcium, bicarbonate, and sulfate, and variable quantities of sodium ( 0 to 25 percent) to water in the Purgatoire River (Water, Waste, and Land, Ltd., 1980, appendix E). These changes are substantially less than those caused by inflowing ground and surface water, reactions with bedrock, and human activity.

Finally, mines--especially open-pit mines--may increase sediment yields to streams. Data are inadequate to quantify this impact. Onsite observations of the Purgatoire River during 1981 indicated no increased muddying of the river near mines and tailings dumps. Yet, tailings dumps are erodible (fig. 2.5.3-4). Such erosion, however, can be minimized by locating the dumps away from the flood plains of the streams. Sump ponds, such as those at currently operating mines, also prevent sediment in mine discharge from reaching nearby streams. In contrast, natural erosion of loosely consolidated bedrock, like the Poison Canyon Formation, can add substantial quantities of sediment to streams. 


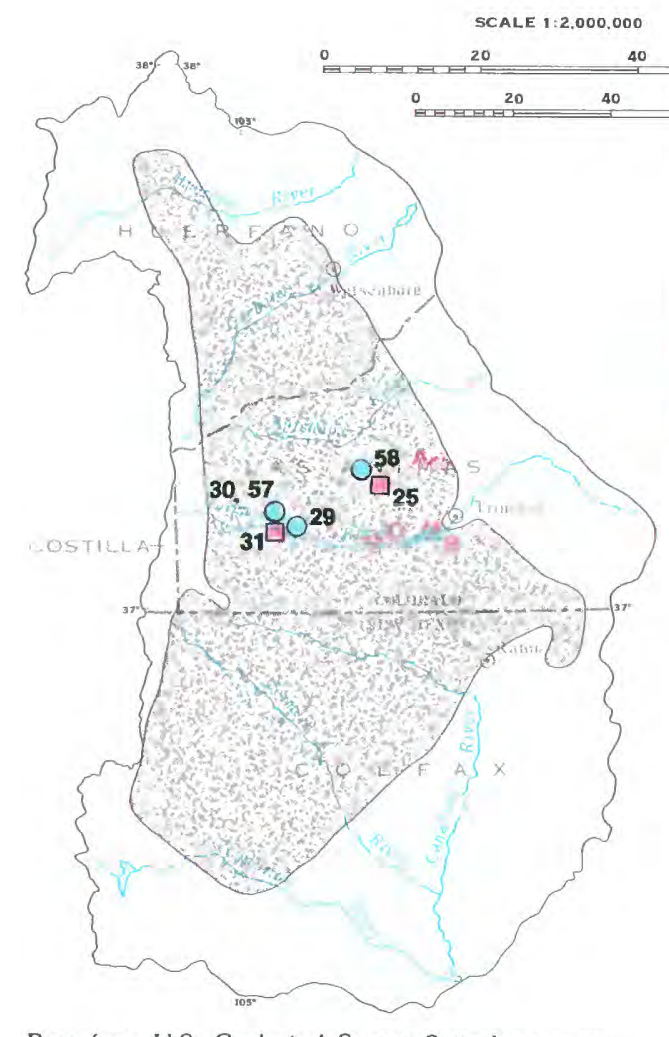

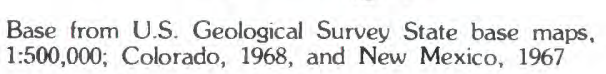
Figure 2.5.3-1 Selected mines and wells
in Raton Basin.

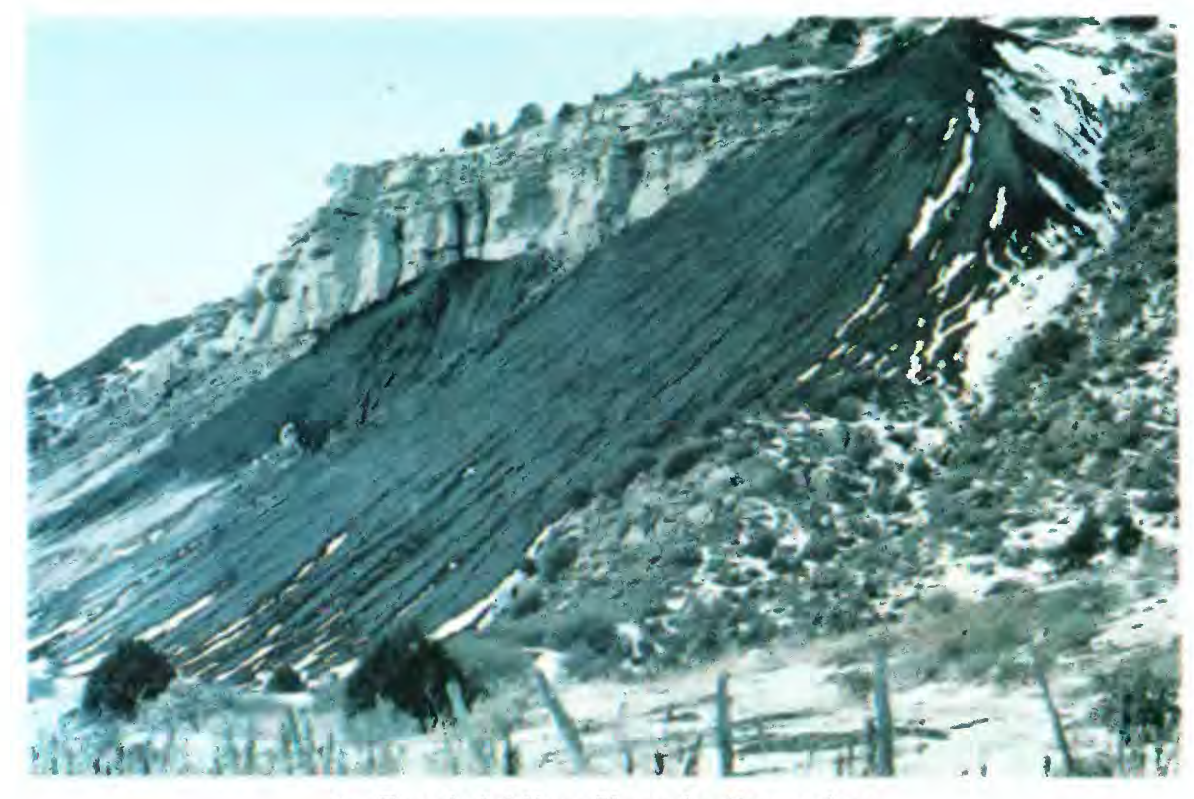
A. Berwind Mine--Vermejo Formation.

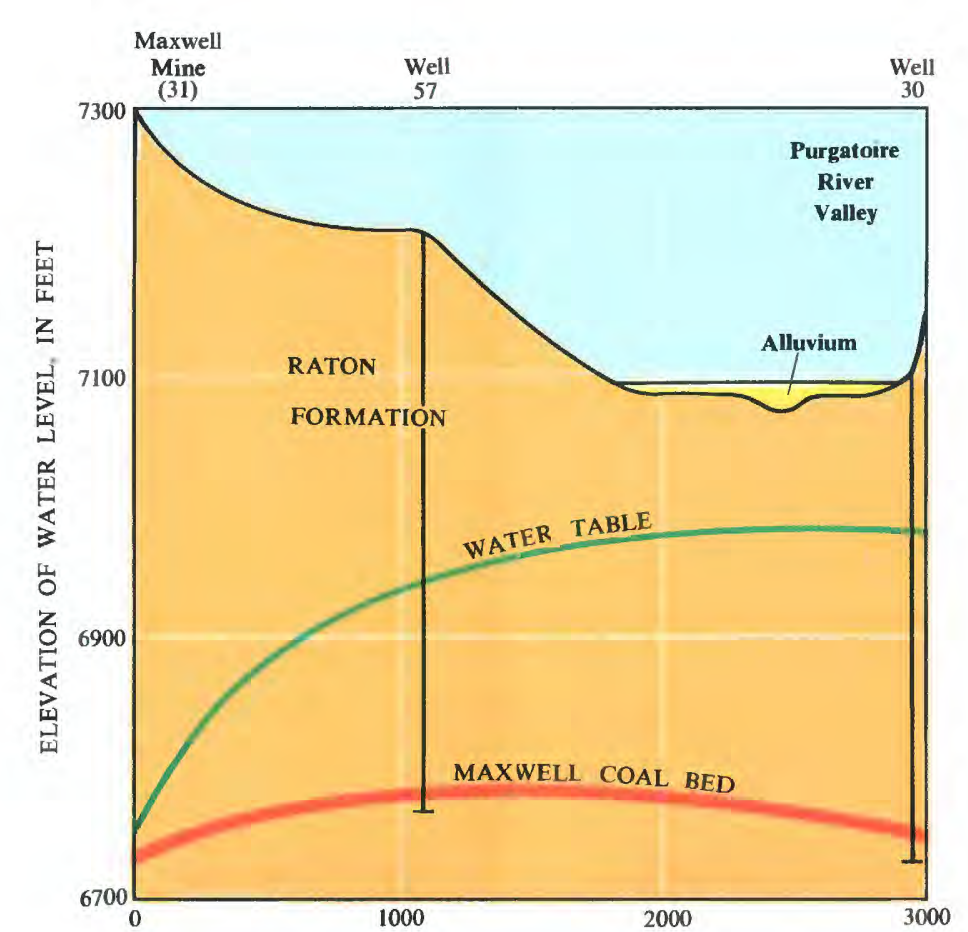

DISTANCE FROM MAXWELL MINE, IN FEET

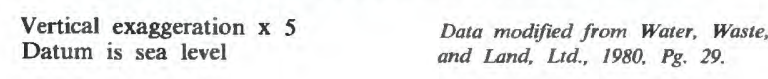
Figure 2.5.3-2 Drawdown of water table by mine
pumps near the Maxwell Mine, Colorado, 1980 .

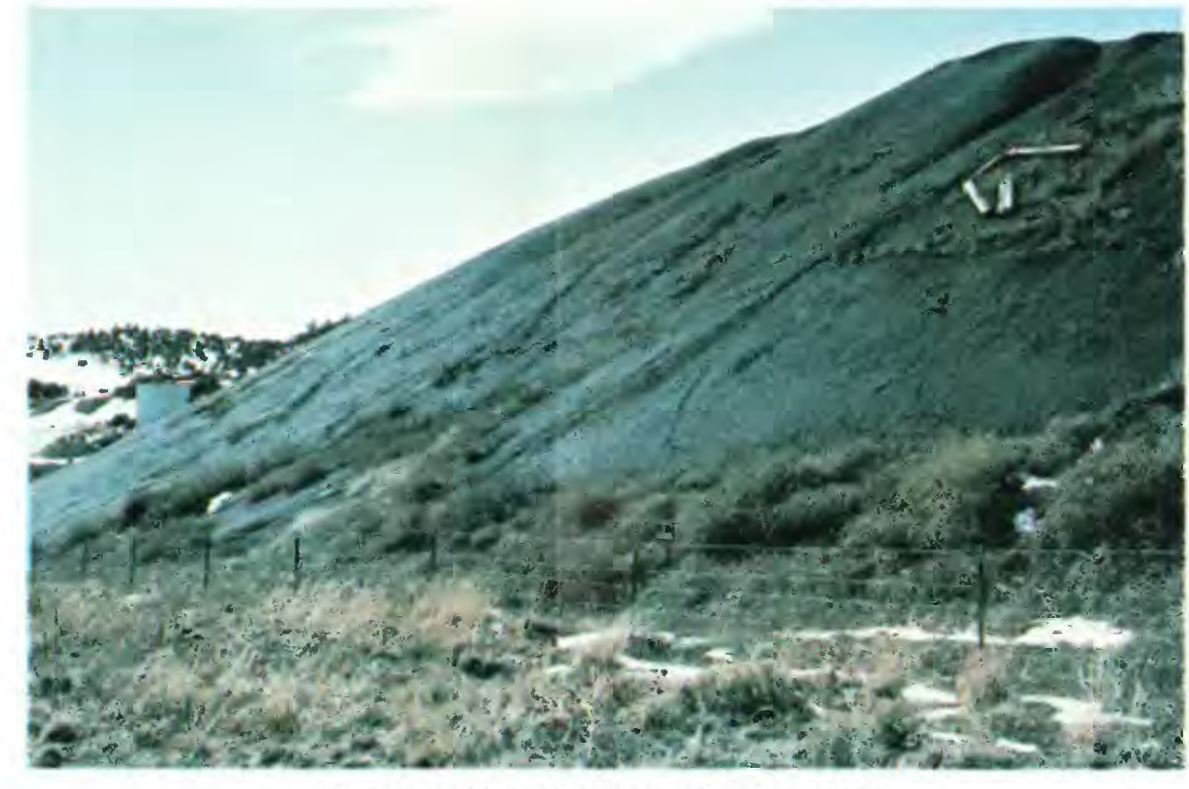

B. Cokedale Mine--Vermejo Formation.

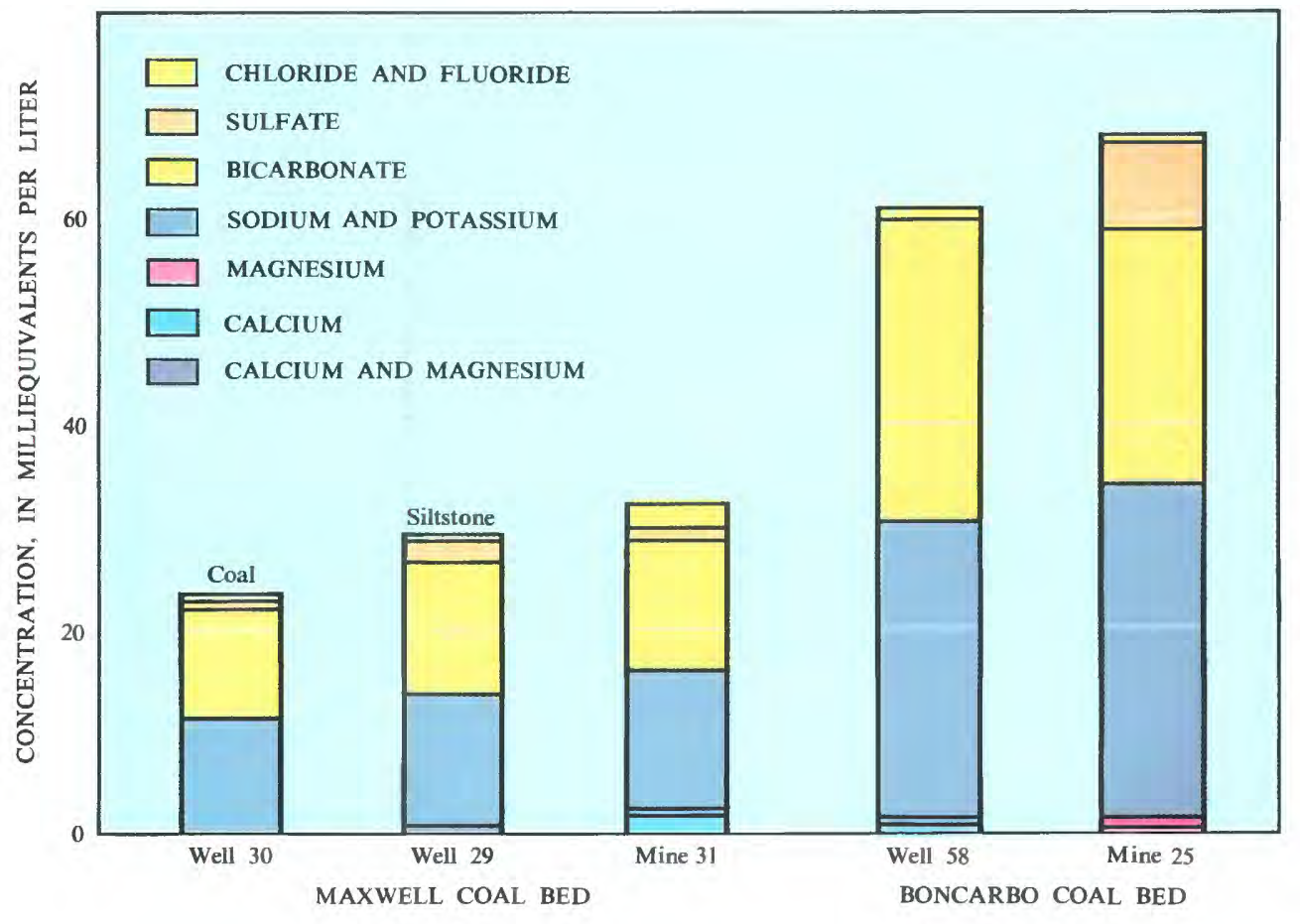

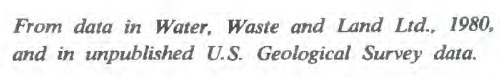
Figure 2.5.3-3 Comparison of ground-water quality in mines and wells discharging
from the Raton Formation.

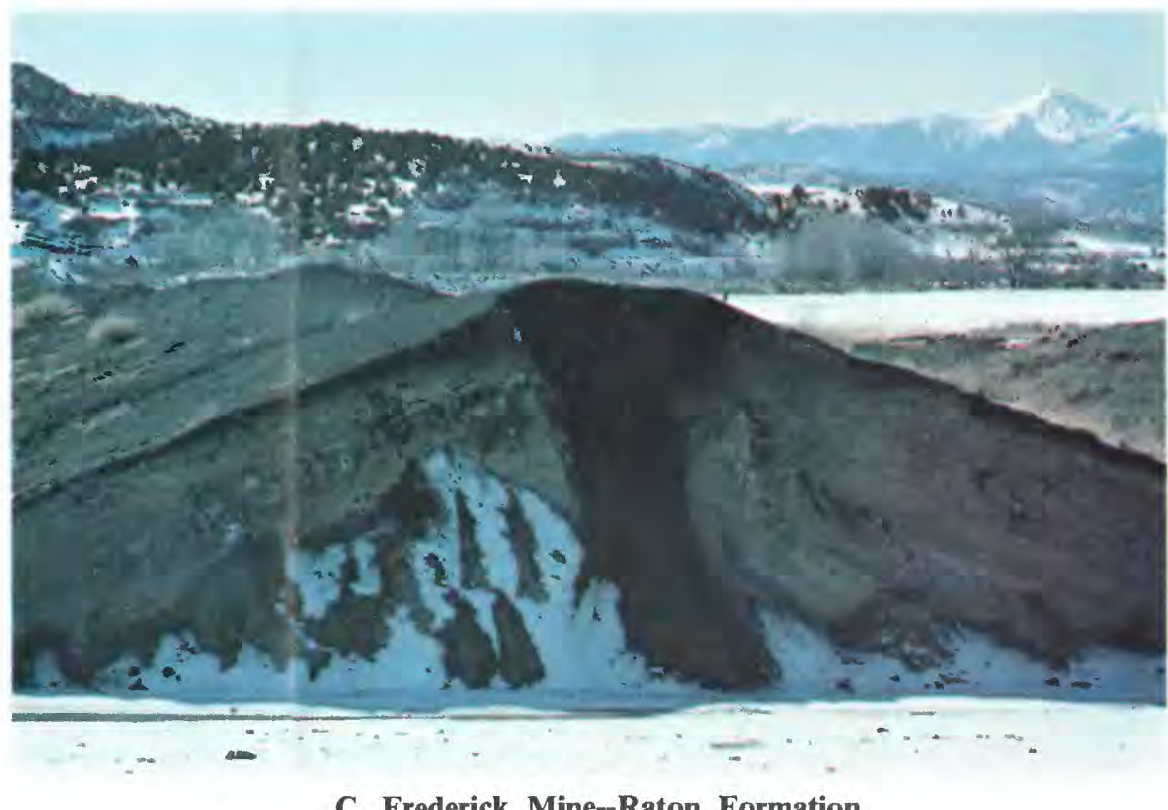

C. Frederick Mine--Raton Formation

Figure 2.5.3-4 Tailings from abandoned mines along the Purgatoire River and its tributaries, Colorado. 


\title{
2.0 GENERAL FEATURES--Continued \\ 2.6 Land Use
}

\section{Livestock Grazing Is the Most Prevalent Use of Land in Area 61}

\author{
Area is predominantly forest and rangeland, and both are used mostly \\ for grazing livestock.
}

Vegetative cover in the area varies from west to east with decrease in land elevation. The grazing of livestock, primarily cattle, is the chief use of this land. Forests at all elevations are used for wildlife management. Most of the active coal mines are on forest lands. Mountain-property subdivisions are under development in the woodlands and forests at lower and intermediate elevations. The mountains provide an attractive setting for recreation, and many Federal, State, municipal, and private facilities are available. Many of the larger private land holdings-especially within the Maxwell Land Grant boundaries--are available for uses such as hunting and fishing by a lease or fee arrangement.

Small areas of tundra are found at the crest of the Culebra Mountains and at the tops of the Spanish Peaks. The timberline at this latitude is about 11,500 feet (ft). Spruce-fir forests grow at elevations between 11,500 and 9,000 ft. Douglas fir and ponderosa pine are dominant between elevations of 9,000 and $6,000 \mathrm{ft}$. Douglas fir is limited to elevations above $7,500 \mathrm{ft}$, and ponderosa pine is not found above $8,000 \mathrm{ft}$ (U.S. Soil Conservation Service, 1976). Interspersed in these evergreen forests are mountain meadows and large groves of aspen. Grazing in the spruce-fir and Douglas-fir forests generally is limited to openings or parks and some older timber stands. Timber is harvested from these forests in commercial quantities. Pinyon-juniper woodlands may be present at elevations between 5,000 and 7,000 $\mathrm{ft}$ but generally are found above $6,000 \mathrm{ft}$ in Area 61 .
The demarcation between the woodland and the open rangelands is about $6,000 \mathrm{ft}$. The rangelands, which are near the eastern and southern edges of the area, consist of plains, breaks, and foothills and are used primarily for livestock grazing. Dryland and irrigated crops are grown.

Irrigated acreages are in the flood plains and at the points where the major streams flow out of the foothills onto the plains. The most notable of these are the lands east of Trinidad, Colo., irrigated by diversions from the Purgatoire River, and west of Springer, N. Mex., irrigated by water from the Cimarron River.

Besides livestock grazing, agriculture, timber cutting, mining operations, wildlife management, and recreation, uses involving smaller areas of land are urban and industrial development, transportation, and water-resources development. No Indian or military land is located within the area.

A generalized land use map of Area 61 is shown in figure 2.6-1. The U.S. Geological Survey publishes a series of Land Use and Land Cover maps on a $1^{\circ} \times 2^{\circ}$ quadrangle format. Land use is delineated in detail on maps of this series. The map covering the Trinidad, Colo., part of Area 61 is currently available (U.S. Geological Survey, 1980). The map of this series covering the Raton, N. Mex., part of the area is scheduled to be available sometime in 1983. 


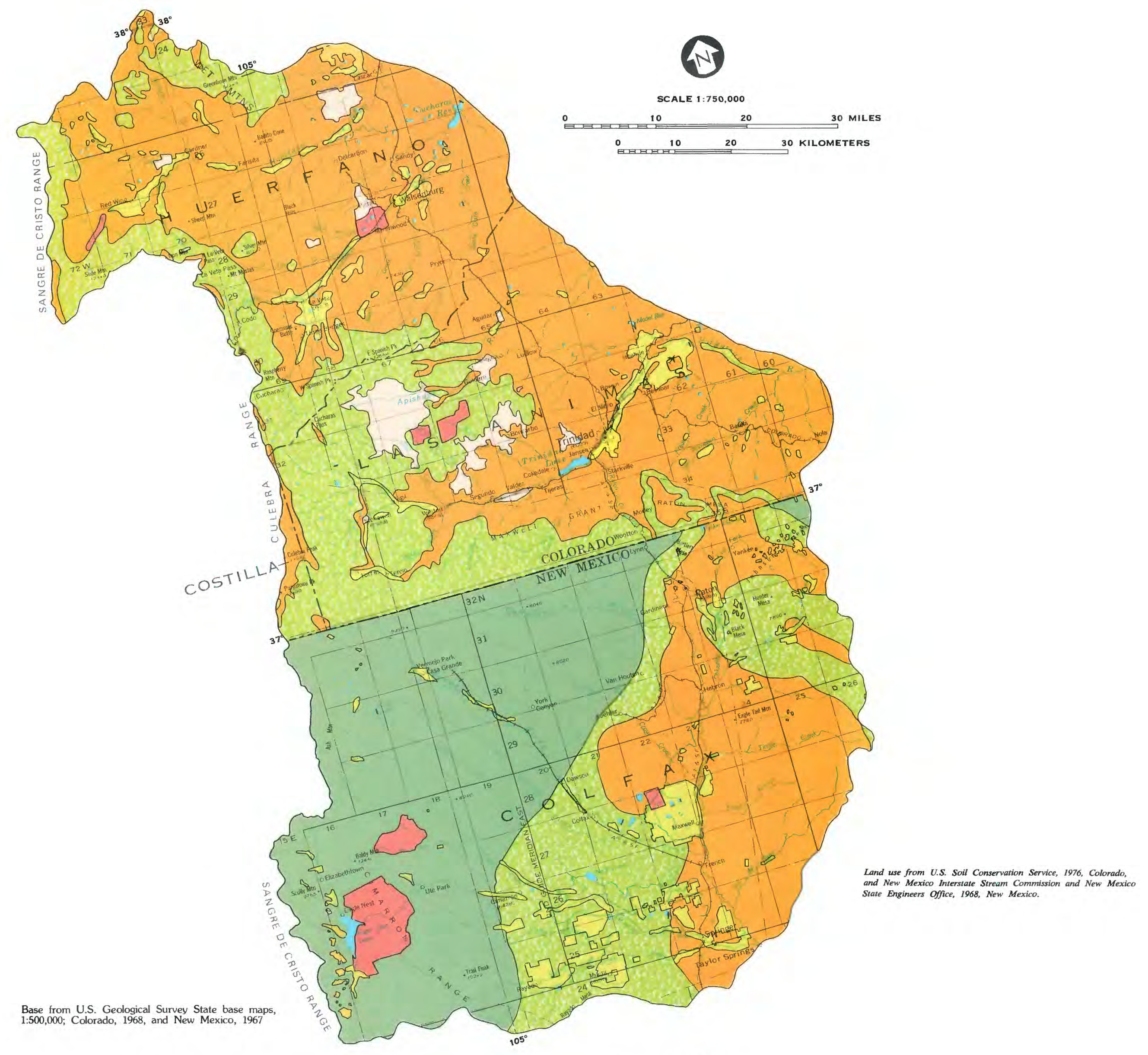

EXPLANATION

COLORADO

Irrigated cropland

Non-irrigated cropland

Rangeland-pastureland

Woodland

Urban

Subdivisions

Recreation land

Waterbody

NEW MEXICO

Irrigated

Dry farmland

Rangeland

Woodland

Recreation land

Timberland

Waterbody 


\title{
Most of the Land in Area 61 Is Privately Owned
}

\author{
The Maxwell Land Grant includes most of the area south of the Purgatoire River \\ in Colorado and nearly all of Colfax County, New Mexico.
}

The U.S. Government was bound by the Treaty of Guadalupe Hidalgo to respect all existing landgrant titles issued by the Mexican Government (Pettit, 1966). The 1,714,765-acre Maxwell Land Grant lies almost entirely within Area 61, encompassing about 45 percent of the 5,900-square-mile area. Most of the lands and associated minerals within the Maxwell Grant are relatively large parcels owned privately by individuals or corporations.

Most of the land north of the Maxwell Grant also is owned privately by individuals or corporations. Within the privately owned section are several million acres in which coal, oil, and gas rights were reserved by the Federal Government.

Publicly owned or administered lands in the area are those owned by the Federal Government, the governments of the two States, and by counties and municipalities. The lands owned by the Federal Government are administered by the U.S. Forest Service, the U.S. Bureau of Land Management, the U.S. Fish and Wildlife Service, and the U.S. Army Corps of Engineers. The Forest Service, with parts of the San Isabel National Forest and a small segment of the Carson National Forest within the area, and the Bureau of Land Management are the Federal agencies administering the most significant parcels of Federal lands. Lands owned by Colorado are administered by the Colorado Land Board, the Colorado Division of Wildlife, and the Colorado Division of Parks and Outdoor Recreation. In New Mexico the lands are administered by the New Mexico Game and Fish Department. The area is about 87-percent privately owned, 7-percent State owned, and 6-percent federally owned. Only minor parcels of land in Area 61 are owned by counties and municipalities. No Indian lands exist in Area 61. Land ownership is shown in figure 2.7-1.

Mineral ownership can be determined from a series of maps published by the U.S. Bureau of Land Management. In Colorado, the Bureau of Land Management has published, at the scale of 1:126,720, a series of Surface-Mineral Management Quadrangles which show the status of land and mineral ownership. The quadrangles in the series that portray Area 61 are SE-11, SE-16, SE-17, SE-21, and SE-22. Surface-Mineral Management Quadrangles' coverage in New Mexico has not been extended to Colfax County. There is, however, a State Land Status Map covering the entire State of New Mexico published by the Bureau of Land Management. 


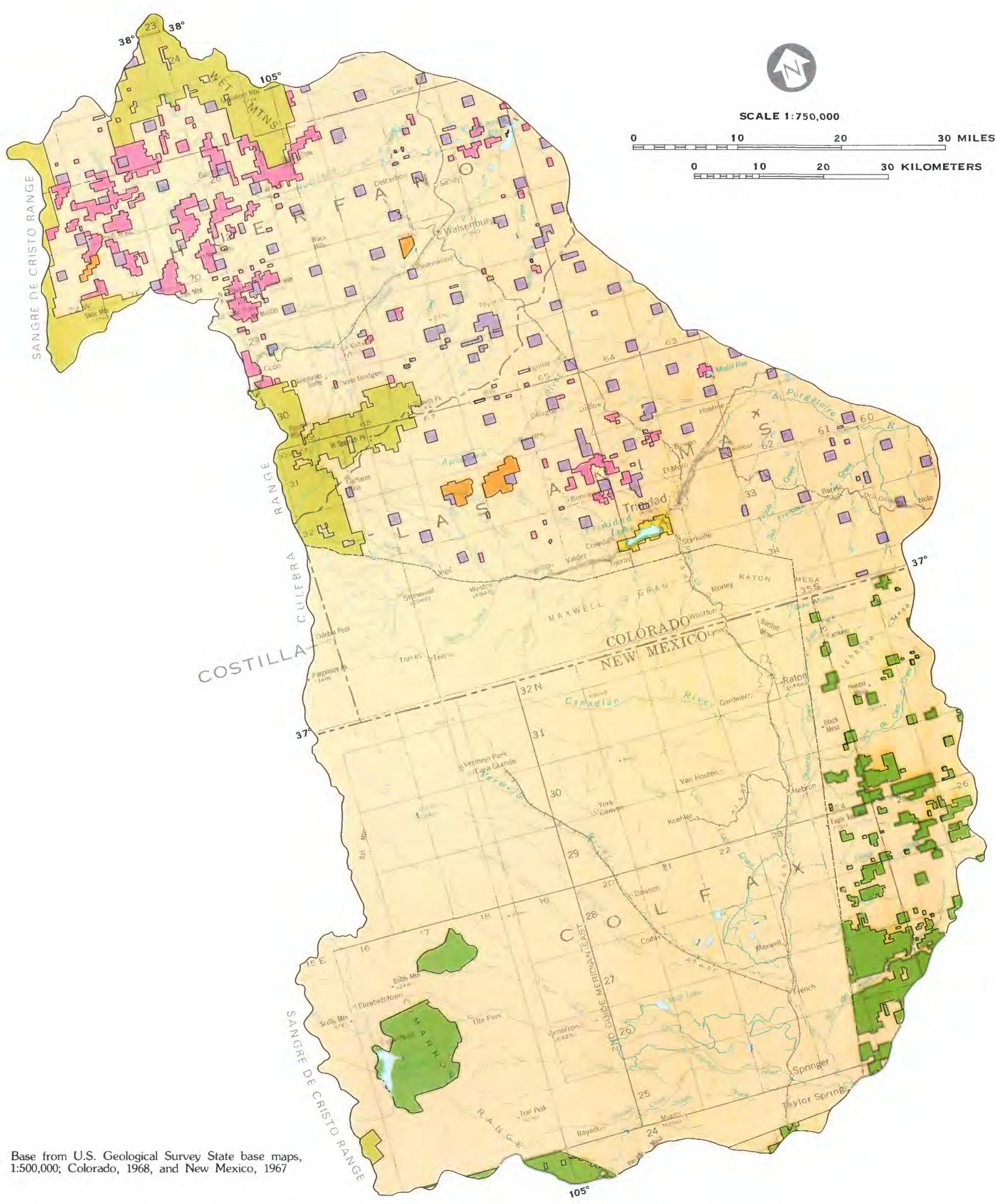

EXPLANATION

\section{FEDERAL LAND}

U.S. Bureau of Land Managemen

U.S. Forest Service

U.S. Army Corps of Engineers

\section{STATE LAND}

State Land Board of Colorado

Colorado Division of Wildlife and Colorado

Divion of Parks and Outdoor Recreation

New Mexico Game and Fish Department

PRIVATE

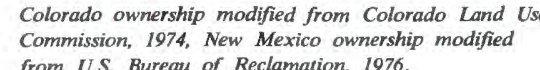




\title{
2.0 GENERAL FEATURES--Continued \\ 2.8 Precipitation
}

\section{Precipitation Increases with Land Elevation}

\author{
In winter, snowfall at the higher elevations brings significant moisture to the \\ area; in summer, thunderstorms at lower elevations are the main contributors \\ of water.
}

The annual precipitation in the area varies with the land-surface elevation and generally increases from east to west as the land slopes upward toward the crest of the Sangre de Cristo Range. The least annual precipitation occurs in the valleys of the major drainages. Mean annual precipitation is shown in figure 2.8-1.

Rainfall is greatest in the late spring and in the summer and is characterized by torrential thunderstorms or cloudbursts. These storms usually occur in relatively small areas, are of short duration, and, because of sparse vegetation and steep gradients, commonly result in flash floods. Monthly distribution of normal precipitation at Trinidad FAA AP (National Oceanic and Atmospheric Administration, 1980 ) is shown in figure 2.8-2.

The depth of snowfall varies considerably from year to year, but during unusual winters, the area might be covered by several feet of snow. The area is void of long-term snow cover, except at high elevations, during most years. The 15 -year average first- of-month (February-May) snow depth and water content at the U.S. Soil Conservation Service's Bourbon snow course (Washichek and others, 1978), which is located near the headwaters of the Purgatoire River, is shown in figure 2.8-3.

Snowpack information is collected during the late winter and early spring by the U.S. Soil Conservation Service and is published as "Water Supply Outlook for Colorado and New Mexico." Daily precipitation data is collected and published monthly as "Climatological Data for Colorado" and "Climatological Data for New Mexico" by the National Oceanic and Atmospheric Administration, National Climatic Center, Asheville, N.C.

Location of snow courses and precipitation gages in and near Area 61 is shown in figure 2.8-1. Descriptive data on precipitation gages currently in operation are summarized in table 2.8-1, and similar data for current snow courses are summarized in table 2.8-2. 


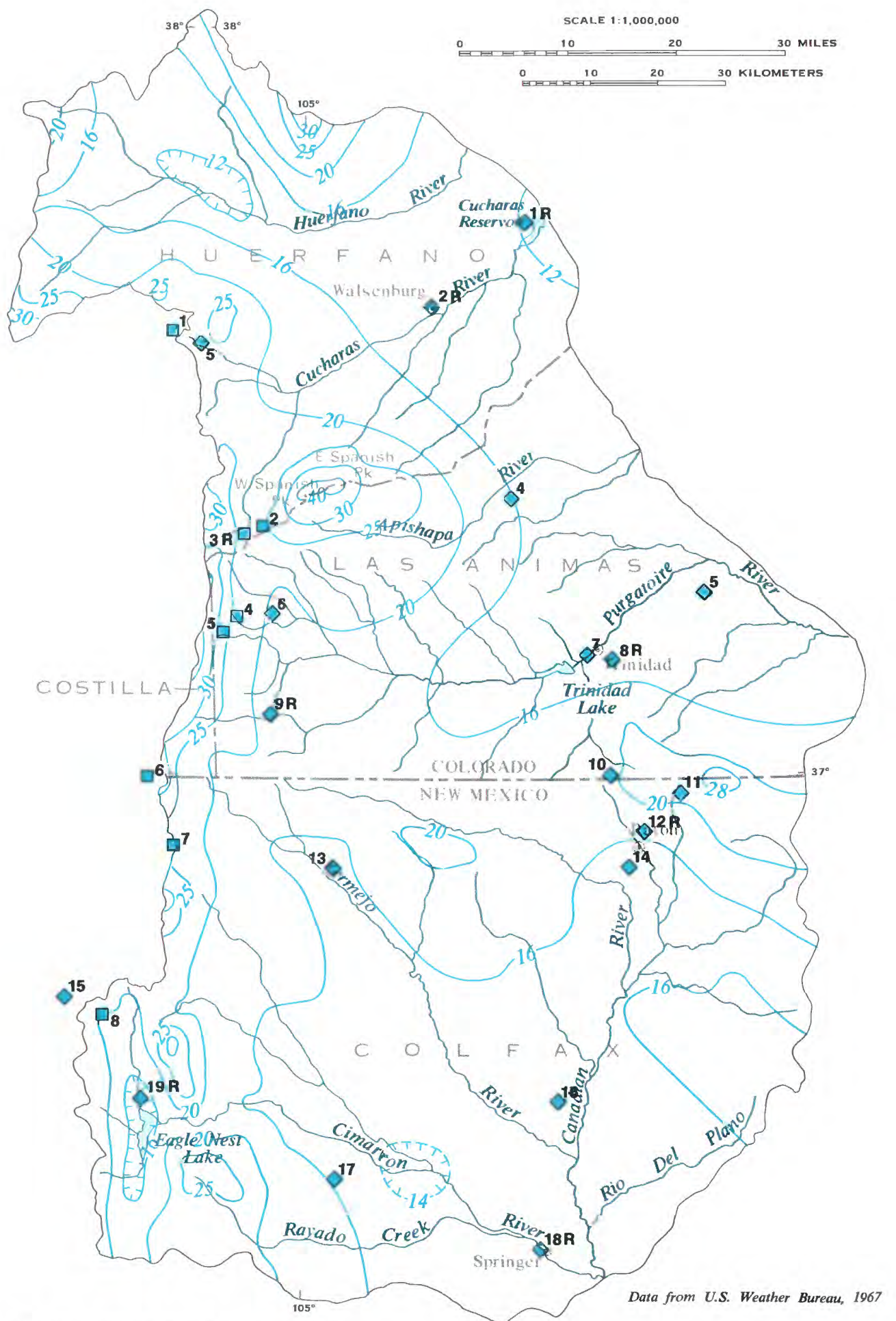

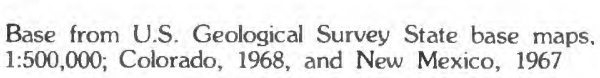

\section{EXPLANATION}

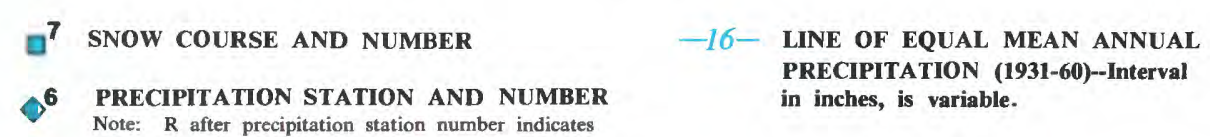

$$
\begin{aligned}
& \text { PRECIPITATION STATION AND NUMBER } \\
& \begin{array}{l}
\text { site for which precipitation data for time } \\
\text { intervals shorter than I day are available. }
\end{array}
\end{aligned}
$$$$
\text { 作 }
$$$$
\text { in inches, is variable. }
$$

\begin{tabular}{|c|c|c|c|c|c|c|}
\hline \multirow{2}{*}{$\begin{array}{l}\text { Map } \\
\text { No. }\end{array}$} & \multirow{2}{*}{$\begin{array}{l}\text { Station } \\
\text { name }\end{array}$} & \multicolumn{4}{|c|}{ Location } & \multirow{2}{*}{$\begin{array}{c}\text { Elevation } \\
\text { (feet above sea level) }\end{array}$} \\
\hline & & Degrees & fitude Minutes & Degrees & $\begin{array}{l}\text { gitude } \\
\text { Minutes }\end{array}$ & \\
\hline 1 & $\begin{array}{l}\text { Cucharas Dam } \\
\text { Walsophor Powerlant }\end{array}$ & & 45 & & 36 & 5,765 \\
\hline 3 & $\begin{array}{l}\text { Mule Shoe Lodge } 1 \text { SSE } \\
\text { Sule Loder }\end{array}$ & 37 & 35 & 105 & 11 & $\begin{array}{l}6,150 \\
8,890\end{array}$ \\
\hline & $\begin{array}{l}\text { Aquilar I SE } \\
\text { Trinidad FAA AP }\end{array}$ & & 23 & & 39 & $\begin{array}{l}6,360 \\
5746\end{array}$ \\
\hline & & & & & & \\
\hline $\begin{array}{l}6 \\
7 \\
\end{array}$ & $\begin{array}{l}\text { North Lake } \\
\text { Trinitad River }\end{array}$ & 37 & 13 & & 03 & 8,800 \\
\hline 8 & Trinidad & & & $\begin{array}{l}104 \\
104\end{array}$ & $\begin{array}{l}31 \\
29\end{array}$ & $\begin{array}{l}5,990 \\
6,030\end{array}$ \\
\hline 9 & & & & 105 & 03 & 8,270 \\
\hline & Wootton Ranch & 37 & 00 & 104 & 29 & 7,575 \\
\hline & Lake Maloya & & 59 & & 22 & 7,400 \\
\hline $\begin{array}{l}12 \\
13\end{array}$ & $\begin{array}{l}\text { Raton Filter Plant } \\
\text { Vermejo Park }\end{array}$ & $\begin{array}{l}36 \\
36\end{array}$ & $\begin{array}{l}55 \\
53\end{array}$ & & $\begin{array}{l}26 \\
57\end{array}$ & $\begin{array}{l}6,920 \\
7,515\end{array}$ \\
\hline & Raton Radio KPTN & & 53 & 104 & 27 & 6,640 \\
\hline & Red River & 36 & 42 & 105 & 24 & 8,676 \\
\hline & Maxwell $3 \mathrm{NW}$ & & 34 & & 34 & 6,015 \\
\hline 17 & Cimarron 4 SW & & 28 & 104 & 57 & 6,540 \\
\hline 19 & $\begin{array}{l}\text { Springer } 2 \mathrm{~N} \\
\text { Eagle Nest }\end{array}$ & & $\begin{array}{l}22 \\
33\end{array}$ & $\begin{array}{l}104 \\
105\end{array}$ & $\begin{array}{l}36 \\
16\end{array}$ & $\begin{array}{l}5,922 \\
8,275\end{array}$ \\
\hline
\end{tabular}

Table 2.8-1 Current (1982) precipitation stations in and near Area 61.

Table 2.8-2 Current (1982) snow courses in and near Area 61.

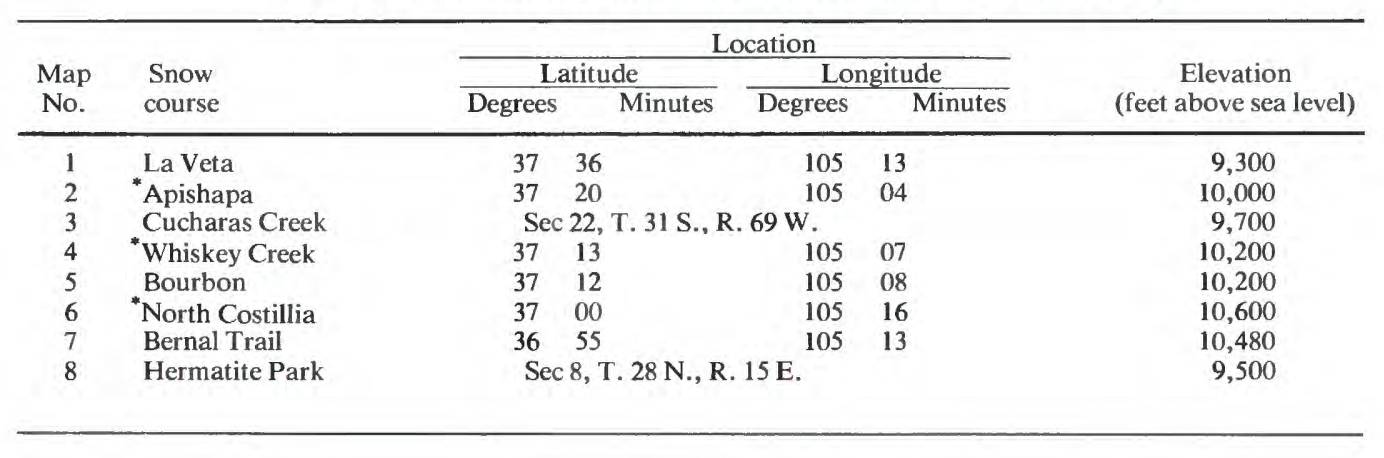

*Snotel installation

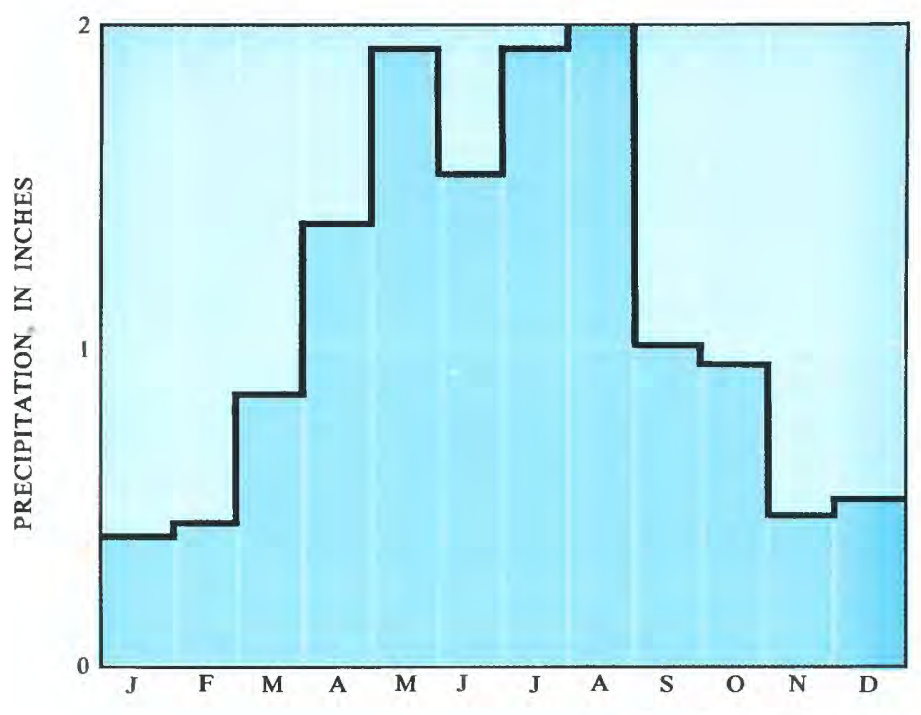

Datat from National Oceanic and
Atmospheric Adrministrataion,

Figure 2.8-2 Normal monthly precipitatio at Trinidad FAA AP, map number 5 .

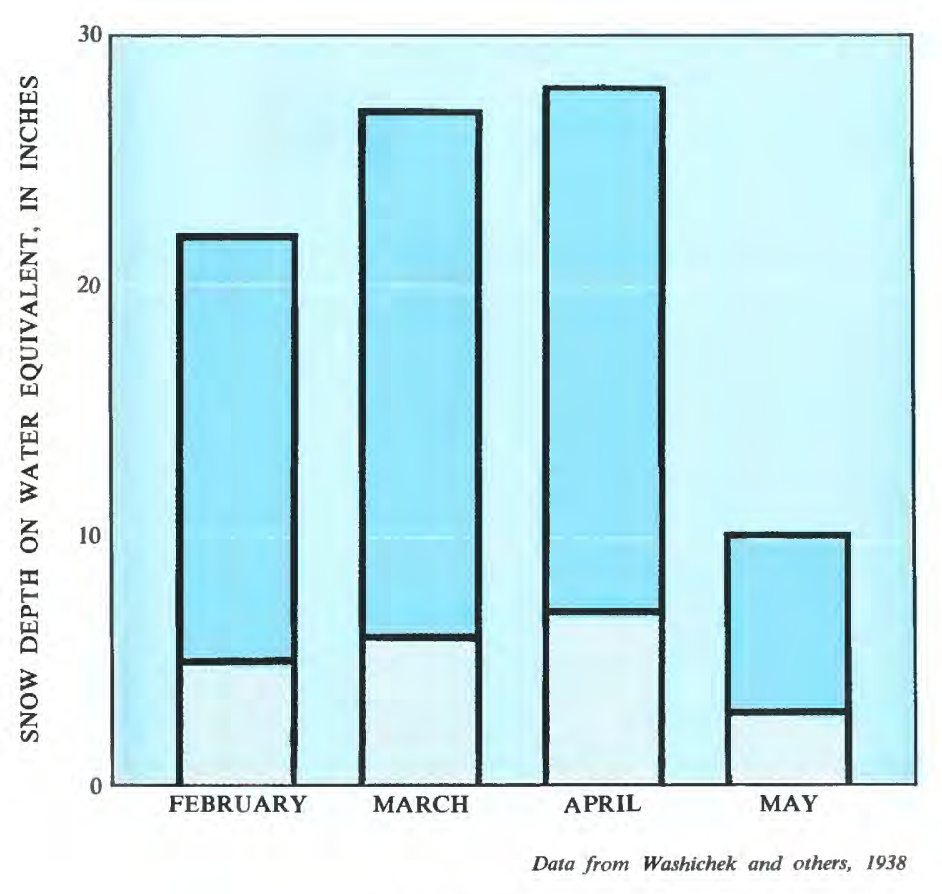

EXPLANATION

Figure 2.8-3 Fifteen-year average first-of-month snow-course data, Bourbon snow course, map number 5 .

2.0 GENERAL FEATURES-- Continued 


\title{
Air Temperature in Area 61 Varies According to Season, Elevation, Hour, and Orientation
}

\author{
Elevation differences can cause air temperatures to change abruptly within \\ a short distance.
}

Air temperature, along with other climatic factors such as wind movement and humidity, establishes the hydrologic characteristics of a region. It affects the distribution and quantity of precipitation, the occurrence of snow and ice, snowmelt, evaporation, and evapotranspiration.

Air temperatures can change abruptly within a short distance in the area if there is a marked change in elevation. Ordinarily, air temperature decreases with increasing altitude at a rate of about $3^{\circ}$ to $5^{\circ} \mathrm{F}$ (Fahrenheit) per 1,000 feet or $6^{\circ}$ to $10^{\circ} \mathrm{C}$ (Celsius) per kilometer. Temperature changes are less noticeable with changes in latitude. Temperature at the station Springer $2 \mathrm{NW}$, at an elevation of 5,922 feet and at $36^{\circ} 22^{\prime}$ latitude, varies little from the station at
Walsenburg Powerplant, at an elevation of 6,150 feet and at $37^{\circ} 38^{\prime}$ latitude, but is markedly different from the station at Red River, at an elevation of 8,676 feet and at latitude $36^{\circ} 42^{\prime}$ (fig. 2.9-1). Normal annual temperature is $50.9^{\circ} \mathrm{F}$ at Springer $2 \mathrm{NW}$, $51.4^{\circ} \mathrm{F}$ at Walsenburg, and $38.3^{\circ} \mathrm{F}$ at Red River.

Because of low humidity and the prevalence of cloud-free days, heat resulting from daytime insolation is quickly dissipated after dark, in both the summer and winter. This results in large diurnaltemperature fluctuations throughout the year. The mean maximum July temperature is shown in figure 2.9-2, and the mean minimum January temperature is shown in figure 2.9-3. 

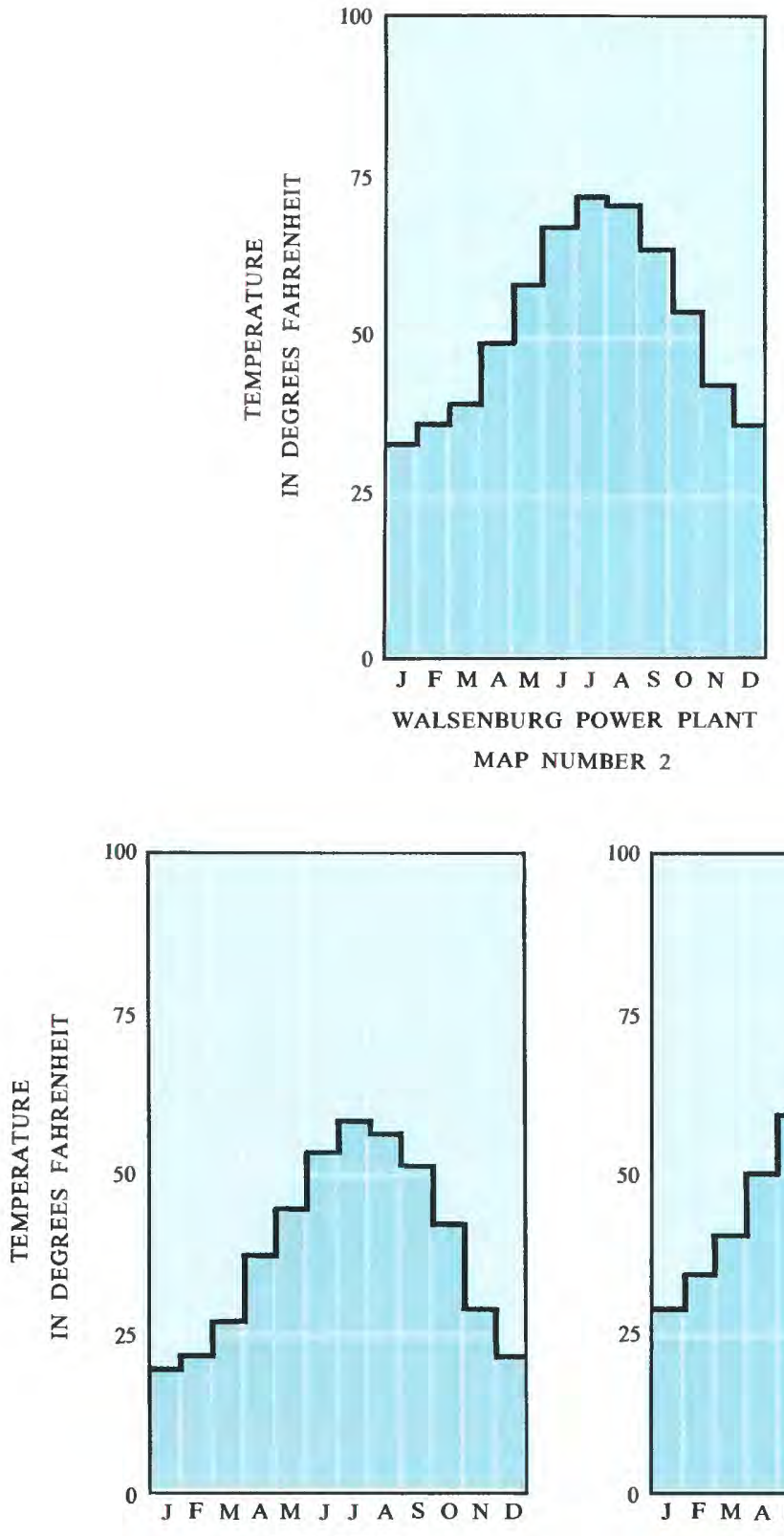

RED RIVER

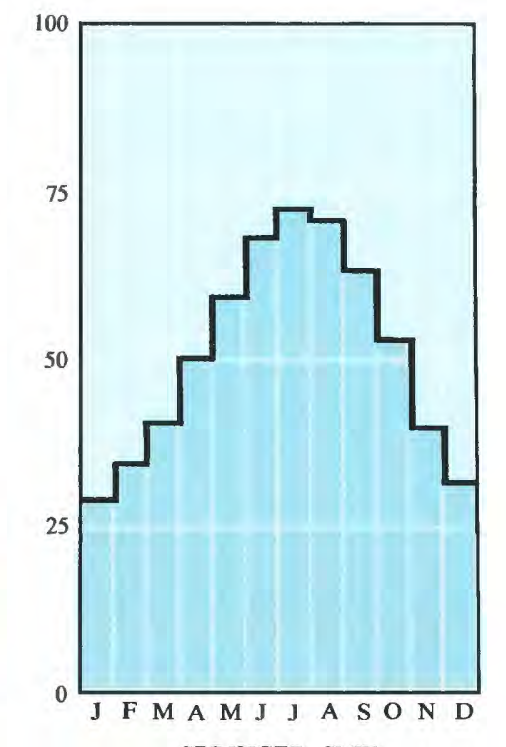

SPRINGER SNW

Figure 2.9-1 Normal monthly temperature

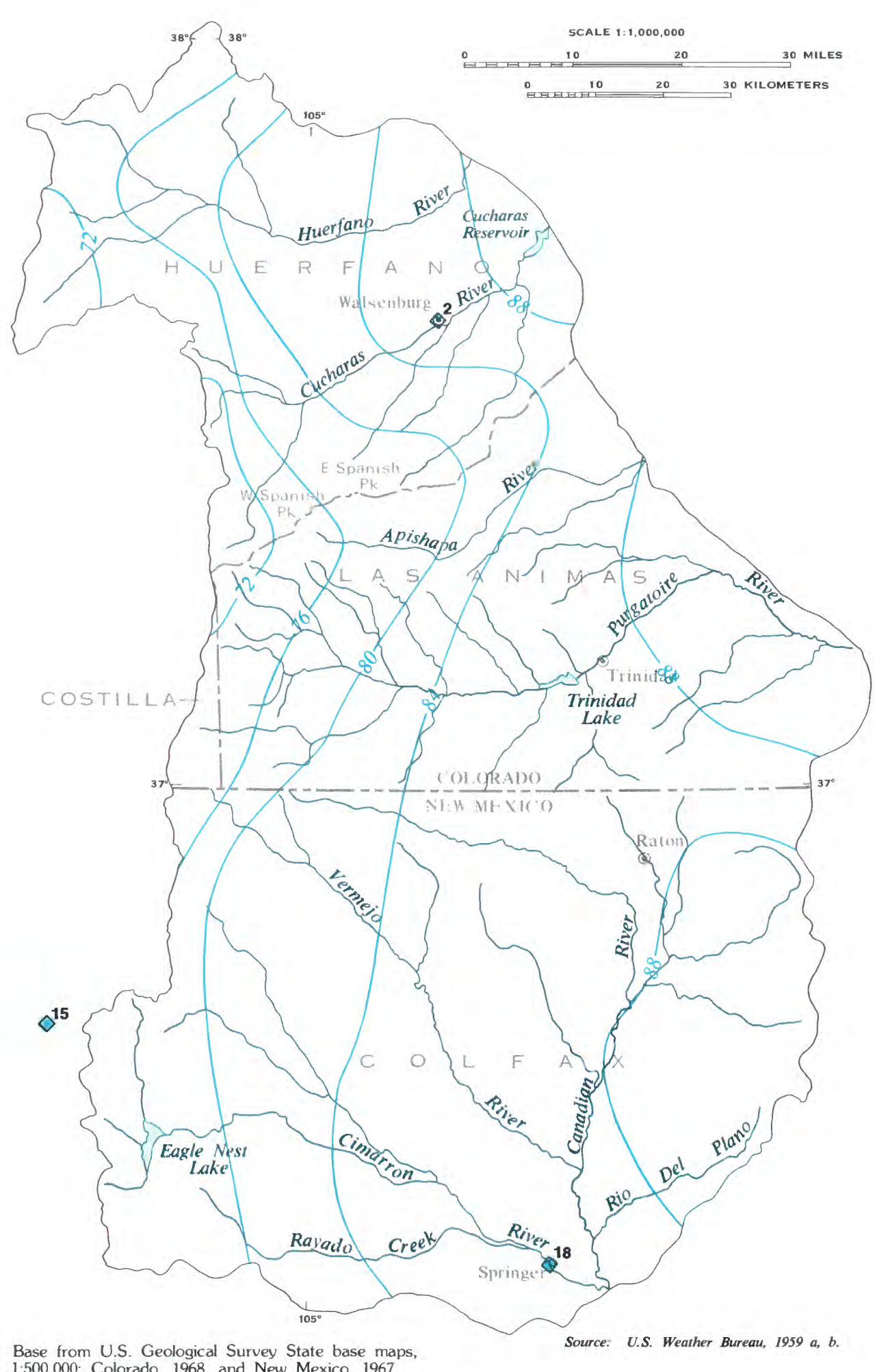

EXPLANATION

80- LINE OF EQUAL MEAN MAXIMUM JULY
TEMPERATURE-INTERVAL 4 $4^{\circ}$ FAHRENHEIT

$\diamond^{18}$ CLIMATE STATION AND NUMBer

Figure 2.9-2 Mean maximum July temperature.

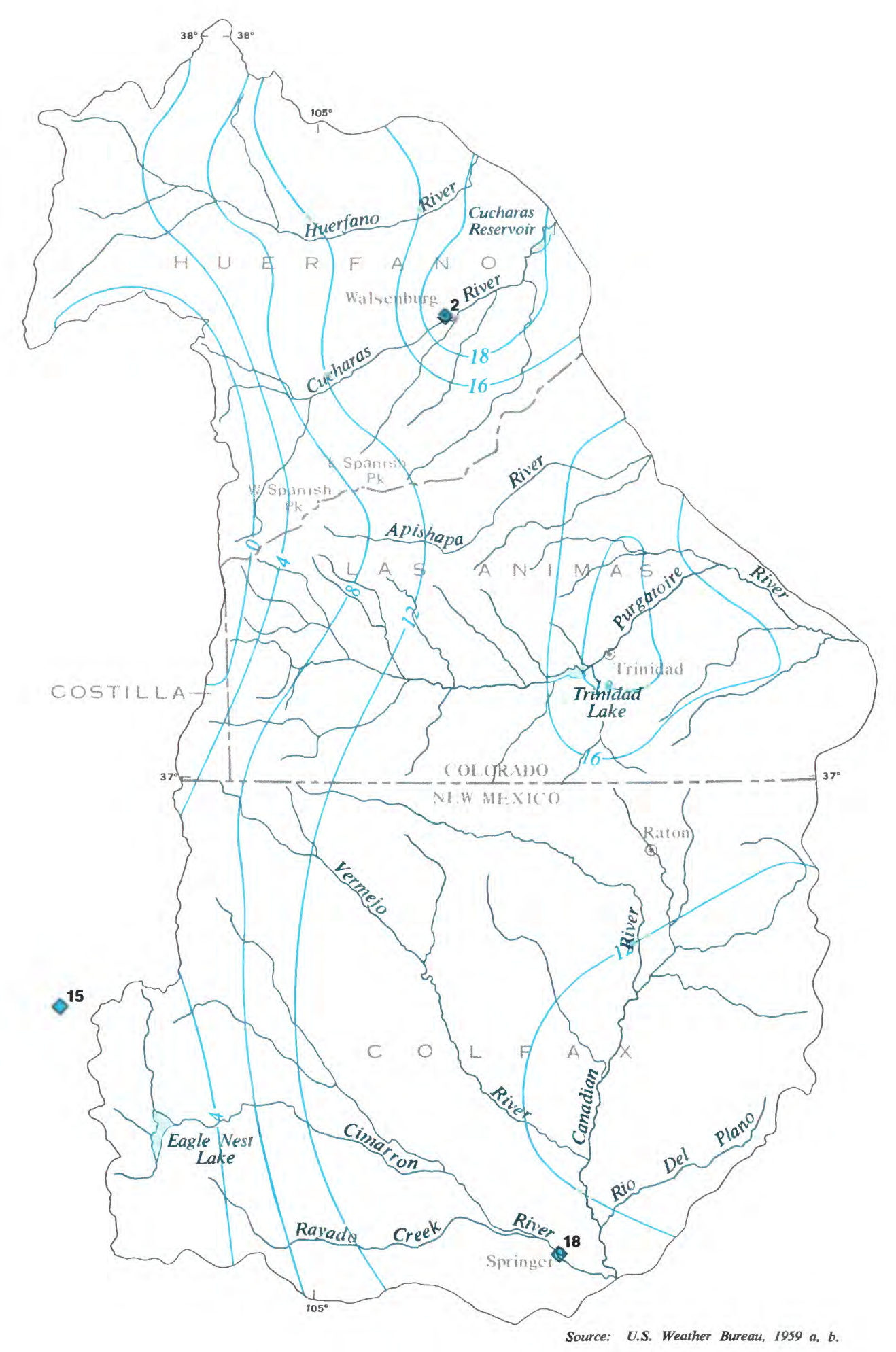

EXPLANATION

-12- UNE OF EQUAL MEAN MAXIMUM JANUARY TEMPERATURE-INTERVAL $2^{\circ}$ AND $4^{\circ}$ FAHRENHEIT $\diamond^{18}$ CLIMATE STATION AND NUMBER

Figure 2.9-3 Mean minimum January temperature. 


\title{
3.0 WATER USE
}

3.1 Water Use During 1980

\section{Irrigated Agriculture Is the Largest User of Water in the Area}

\author{
Surface water, withdrawn for agricultural irrigation under the doctrine of \\ prior appropriation, constitutes the largest water use.
}

\begin{abstract}
Water withdrawal in Colfax County, N. Mex., is shown in figure 3.1-1. This pattern of use is typical of that found throughout Area 61. The largest percentage of use is for irrigation. Crops grown on irrigated land include corn, small grains, alfalfa, and other hay and irrigated pasture--including native pasture. Gravity flow is the principal type of irrigation practiced.
\end{abstract}

Evaporation from lake surfaces is the second largest category of withdrawal and the largest nonbeneficial use of water in the area. Livestock use, including stock-pond evaporation, is the third greatest use, followed by municipal and industrial use; recreational use, including fish and wildlife; and rural domestic and mineral-production uses. To date (1982), water use for power generation is negligible. Ground water provides only a small percentage of water used in the area; livestock and rural domestic are the principal uses of ground water. An increased use of ground water for irrigation could be expected in the future. Of the water used in Colfax County during 1980, 30 percent was returned to the streams for a net depletion of 70 percent.

The waters of both Colorado and New Mexico belong to the people of the States. The right to the use of the water is guaranteed by the doctrine of prior appropriation or "first in time, first in right." Administration of these rights is by the State Engineer of each State. Streamflow of both States is overap- propriated; in other words, there are more rights than there is water in the streams. The result is only the more senior rights are permitted to divert water most of the time. Most of the junior rights can divert water only during floods or periods of excessive runoff. Except for small stock ponds, a storage right is required to store and retain surface water. Storage rights are administered in the priority system in conjunction with streamflow rights.

Wells in Colorado must be adjudicated if they yield more than 15 gallons per minute; wells existing before enactment of the law in 1969 need not be adjudicated if they yield less than 50 gallons per minute. A decree may be required for wells of any capacity. A permit is required to drill a new well (Radosevich and others, 1976).

That part of Area 61 in New Mexico is within a declared underground water basin--the Canadian River basin (New Mexico Interstate Stream Commission and the New Mexico State Engineers Office, 1975), and development of ground water therefore is administered by the New Mexico State Engineer. Permits and the use of licensed well drillers are required for all wells except driven wells that are less than $2-3 / 8$ inches in diameter. The law prohibits mine dewatering in a declared underground water basin without a valid mine-dewatering permit. 


\section{* GROUNDWATER 1 PERCENT}

MINERAL PRODUCTION 2 PERCENT

LIVESTOCK

48 PERCENT

RECREATION, INCLUDING

FISH AND WILDLIFE 23 PERCENT

RURAL DOMESTIC

27 PERCENT

100 PERCENT

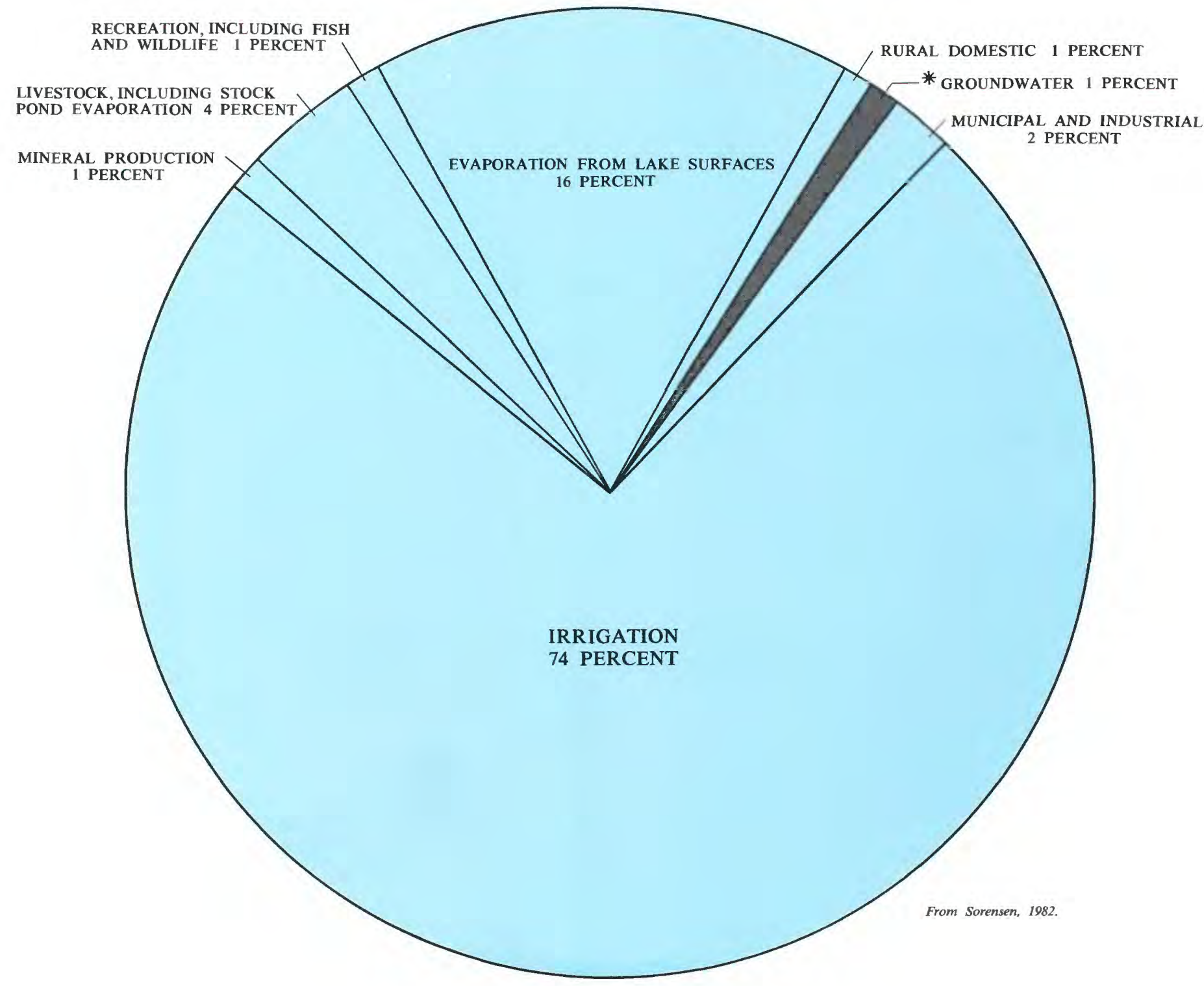

Figure 3.1-1 Water withdrawals during 1980 in Colfax County, New Mexico. 


\title{
3.0 WATER USE--Continued \\ 3.2 Surface-Water Storage
}

\section{Trinidad Lake Is the Only Federal Storage Facility in the Area}

\author{
Reservoirs in the area are used for flood control and storage of surface water \\ for agricultural, municipal, industrial, and recreational uses.
}

Due to seasonal variation of runoff of streams in the area, storage of water in ponds, lakes, and reservoirs is necessary to assure a more effective use of water. Surface-water storage is of concern to those engaged in coal mining because of water-supply needs and because any potential increase in sediment yield due to mining could have an adverse impact on the sedimentation rate in downstream reservoirs.

Trinidad Lake (fig. 3.2-1) is the only Federal storage facility in Area 61. A U.S. Army Corps of Engineers project on the Purgatoire River just upstream from Trinidad, Colo., constructed the reservoir that is used primarily for flood-control protection for that city. Conservation and recreation storage space also is allocated.

Initial space allocation in Trinidad Lake is:
Flood control, 51,000 acre-feet; irrigation, 20,000 acre-feet; joint use, 39,000 acre-feet; and recreation, 4,500 acre-feet. Under initial conditions, the recreation pool has a surface area of 213 acres; the conservation pool has a surface area of 1,382 acres. The joint-use pool is that reservoir capacity reserved for sediment accumulation. Until filled with sediment, the joint-use pool will be used for conservation storage and flood control. The conservation pool regulates an irrigation supply for 19,717 acres of land in the Purgatoire Irrigation District downstream from the city of Trinidad.

Lakes and reservoirs in Area 61 having a surface area greater than 40 acres are listed in table 3.2-1 and are shown in figure 3.2-2. Most of the lakes and reservoirs are in the eastern part of the area.

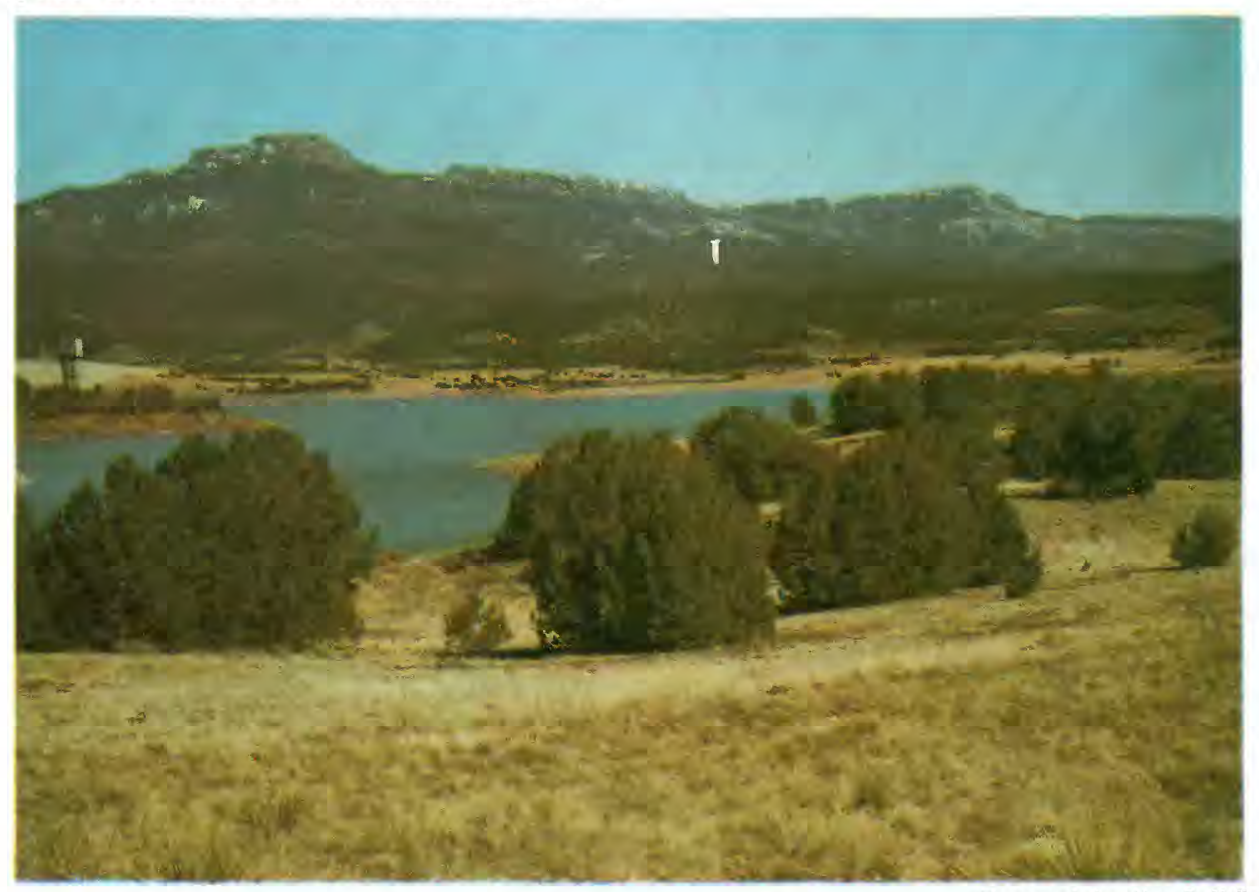

Figure 3.2-1 Trinidad Reservoir on the Purgatoire River near Trinidad, Colorado. Trinidad Dam on left, Fisher Peak and Raton Mesa in background. Reservoir stage almost at minimum pool level. 


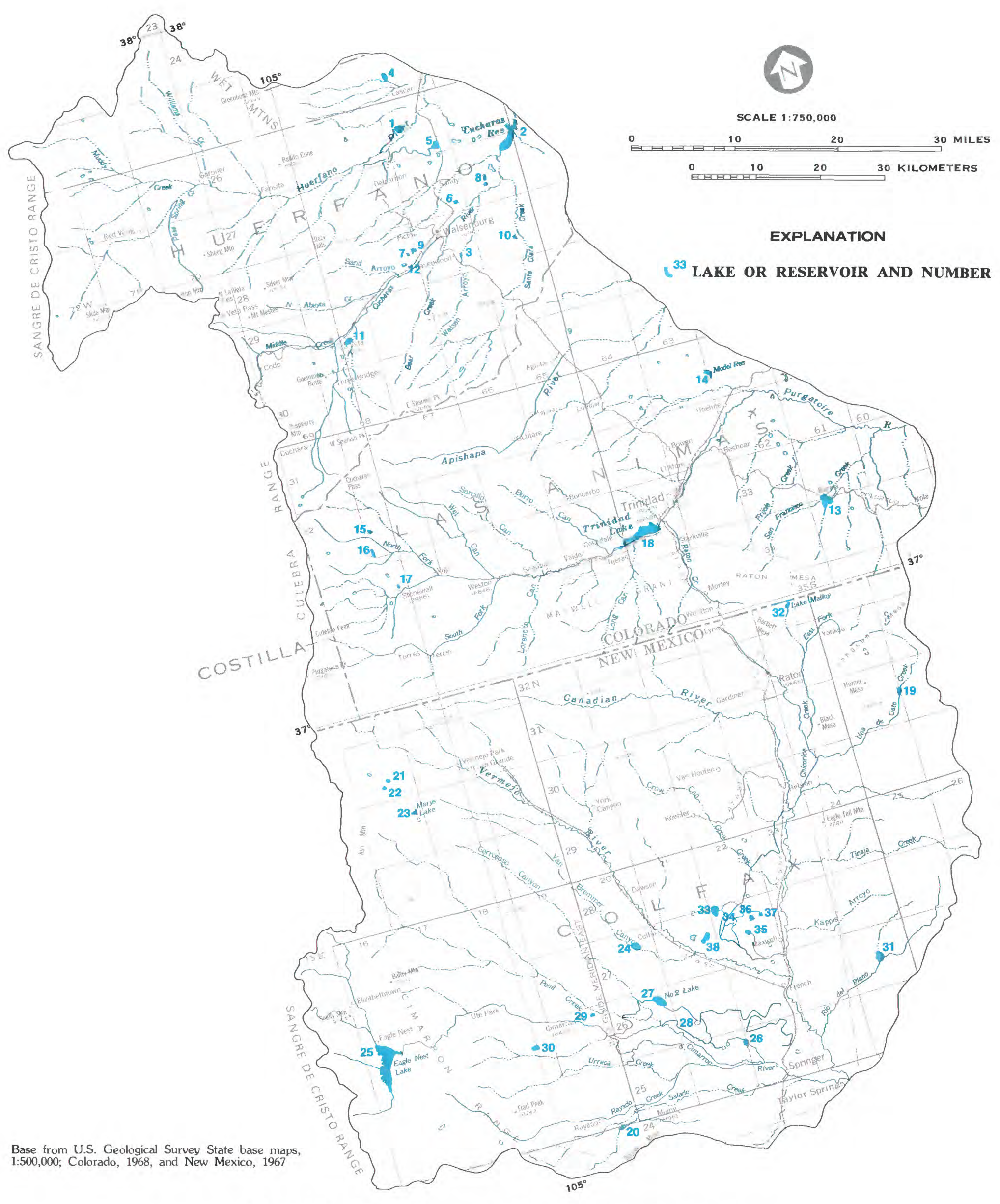

Table 3.2-1 Lakes and reservoirs in Area 61 with surface area greater than 40 acres.

\begin{tabular}{|c|c|c|c|c|c|c|c|}
\hline $\begin{array}{l}\text { Map } \\
\text { No. }\end{array}$ & Name and stream & Township & $\begin{array}{c}\text { Location } \\
\text { Range }\end{array}$ & Section & $\begin{array}{c}\text { Surface } \\
\text { area } \\
\text { (acres) }\end{array}$ & Use & Administrative Agency \\
\hline \multicolumn{8}{|c|}{ Lakes and reservoirs in Colorado } \\
\hline $\begin{array}{l}1 \\
2 \\
3 \\
4 \\
5\end{array}$ & 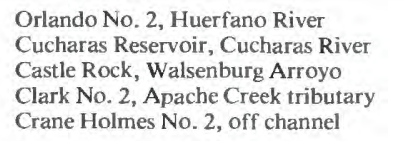 & $\begin{array}{l}26 \mathrm{~S} . \\
26 \mathrm{~S} \\
28 \mathrm{~S} \\
25 \mathrm{~S} \\
26 \mathrm{~S}\end{array}$ & $\begin{array}{l}66 \mathrm{~W} . \\
64 \mathrm{~W} . \\
66 \mathrm{~W} . \\
66 \mathrm{~W} . \\
66 \mathrm{~W} .\end{array}$ & $\begin{array}{l}20 \\
30 \\
22 \\
20 \\
35\end{array}$ & $\begin{array}{l}\mathrm{ND} \\
\mathrm{ND} \\
134 \\
78 \\
120\end{array}$ & $\begin{array}{l}1 \\
\mathrm{I} \\
\mathrm{I} \\
\mathrm{S}, \mathrm{I} \\
\mathrm{S}\end{array}$ & $\begin{array}{l}\text { Nortek Properties, Inc. } \\
\text { Huerfano Cucharas Irrigation Co. } \\
\text { Private } \\
\text { Do. } \\
\text { Do. }\end{array}$ \\
\hline $\begin{array}{r}6 \\
7 \\
8 \\
9 \\
10\end{array}$ & $\begin{array}{l}\text { Holita, Cucharas River } \\
\text { Lake Miriam, cucharar River } \\
\text { Maraia Cucharas River } \\
\text { Lake Cohm, Cucharas River } \\
\text { Salida, Hezron Gulch }\end{array}$ & $\begin{array}{l}27 \mathrm{~s} . \\
28 \mathrm{~S} \\
27 \mathrm{~s} \\
28 \mathrm{~S} \\
28 \mathrm{~S}\end{array}$ & $\begin{array}{l}66 \mathrm{~W} . \\
67 \mathrm{~W} . \\
65 \mathrm{~W} . \\
66 \mathrm{~W} . \\
65 \mathrm{~W} .\end{array}$ & $\begin{array}{l}35 \\
13 \\
21 \\
18 \\
22\end{array}$ & $\begin{array}{l}103 \\
172 \\
200 \\
200 \\
300\end{array}$ & $\begin{array}{l}\mathrm{I} \\
\mathrm{R} \\
\mathrm{R}, \mathrm{I} \\
\mathrm{R} \\
\mathrm{I}, \mathrm{S}\end{array}$ & $\begin{array}{l}\text { Do. } \\
\text { Colorado Division of Wildlife } \\
\text { Dye Construction C. } \\
\text { City of Walsenburg } \\
\text { Private }\end{array}$ \\
\hline $\begin{array}{l}11 \\
12\end{array}$ & $\begin{array}{l}\text { Wahatorya, Cucharas River } \\
\text { Walsenburg Water Supply, Cucharas }\end{array}$ & $29 \mathrm{~s}$. & $68 \mathrm{w}$. & 22 & 55 & D & City of Walsenburg \\
\hline $\begin{array}{l}13 \\
14 \\
15\end{array}$ & $\begin{array}{l}\text { River } \\
\text { Hermosa Valley, Ocana Creeek } \\
\text { Moddel Black Hills } \\
\text { Northoy Lake, North Fork }\end{array}$ & $\begin{array}{l}28 \mathrm{~S} \\
34 \mathrm{~S} \\
31 \mathrm{~S} \\
32 \mathrm{~S}\end{array}$ & $\begin{array}{l}67 \mathrm{~W} . \\
61 \mathrm{~W} . \\
62 \mathrm{~W} \\
68 \mathrm{~W}\end{array}$ & $\begin{array}{l}23 \\
5 \\
19 \\
19\end{array}$ & $\begin{array}{r}67 \\
121 \\
1,198 \\
104\end{array}$ & $\begin{array}{l}\text { D } \\
\text { I } \\
\text { ws }\end{array}$ & $\begin{array}{l}\text { Do. } \\
\text { Private } \\
\text { Citr of Trinidad } \\
\text { Do. }\end{array}$ \\
\hline \multirow[t]{2}{*}{$\begin{array}{l}16 \\
17 \\
18\end{array}$} & $\begin{array}{l}\text { Monument Lake, North Fork } \\
\text { Russell, Middele Fork } \\
\text { Trinidad Reservoir, Purgatoire River }\end{array}$ & $\begin{array}{l}\text { 32S. } \\
\text { Lat } 37^{\circ} 09 \\
33 \mathrm{~S} .\end{array}$ & 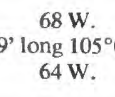 & & $\begin{array}{r}102 \\
40 \\
1,650\end{array}$ & $\begin{array}{l}\text { WS } \\
\text { I } \mathrm{FC,I,R}\end{array}$ & $\begin{array}{l}\text { Do. } \\
\text { Private } \\
\text { U.S. Army Corps of Engineers }\end{array}$ \\
\hline & \multicolumn{7}{|c|}{ Lakes and reservoirs in New Mexico } \\
\hline $\begin{array}{l}19 \\
20\end{array}$ & $\begin{array}{l}\text { Throttle Reservoir, Una del Gato } \\
\text { Creek } \\
\text { Miami Lake No. 2, Rayado Creek }\end{array}$ & $24 \mathrm{~N}$. & $\begin{array}{l}25 \mathrm{E} . \\
19 \mathrm{E} .\end{array}$ & ${ }_{2}^{13}$ & $\begin{array}{l}150 \\
212\end{array}$ & ${ }_{\mathrm{I}, \mathrm{R}}$ & $\begin{array}{l}\text { T.o. Ranchc Co. } \\
\text { Miami Water Users Association }\end{array}$ \\
\hline \multirow{2}{*}{$\begin{array}{l}21 \\
22 \\
23 \\
24 \\
25\end{array}$} & \multirow{2}{*}{$\begin{array}{l}\text { Bartlett Lake, Leandro Creek } \\
\text { Adams LLake, Leandro Creek } \\
\text { Marry's Lake, Van Bremer Canyon } \\
\text { Van Bremer Reservoir, Van Bremer } \\
\text { Arroyo Rer Rer } \\
\text { Eagle Nest Lake, Cimarron River }\end{array}$} & 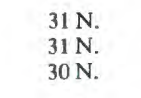 & $\begin{array}{l}\text { 17E. } \\
17 \mathrm{E} . \\
17 \mathrm{E} .\end{array}$ & $\begin{array}{l}23 \\
22 \\
29\end{array}$ & 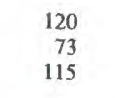 & $\begin{array}{l}\mathrm{R} \\
\mathrm{R} \\
\mathrm{R}\end{array}$ & $\begin{array}{l}\text { Vermejo Park Corp. } \\
\text { Do. } \\
\text { Do. }\end{array}$ \\
\hline & & $\begin{array}{l}27 \mathrm{~N} . \\
27 .\end{array}$ & $\begin{array}{l}20 \mathrm{E} . \\
16 \mathrm{E}\end{array}$ & $\begin{array}{l}100 \\
34\end{array}$ & $\begin{array}{r}71 \\
2,426\end{array}$ & $\begin{array}{l}\mathrm{I} \\
\mathrm{I}, \mathrm{R}, \mathrm{WS}\end{array}$ & $\begin{array}{l}\text { Do. } \\
\text { Charles Springer Cattle Co. }\end{array}$ \\
\hline \multirow[t]{2}{*}{26} & \multirow{3}{*}{$\begin{array}{l}\text { Springer Lake, Cimarron River } \\
\text { Antelope Ealley No. } 2 \text { Reservoir, } \\
\text { Cimarron River } \\
\text { Antelope Valley No. } 3 \text { Reservoir, } \\
\text { Cimarron River } \\
\text { French Lake, Cimarron River } \\
\text { Websters Lake, Cimarroncito Creek }\end{array}$} & $25 \mathrm{~N}$. & $22 \mathrm{E}$. & 17 & 391 & I & Springer Ditch Co. \\
\hline & & $26 \mathrm{~N}$. & $20 \mathrm{E}$ & 11 & 430 & I & $\begin{array}{l}\text { Antelope Valley Irrigation } \\
\text { Distric }\end{array}$ \\
\hline${ }_{30}^{29}$ & & $\begin{array}{l}26 \mathrm{~N} . \\
26 \mathrm{~N} . \\
26 \mathrm{~N}\end{array}$ & $\begin{array}{l}21 \mathrm{E} . \\
19 \mathrm{E} . \\
18 \mathrm{E}\end{array}$ & $\begin{aligned} 28 \\
2 \\
14\end{aligned}$ & $\begin{array}{l}119 \\
72 \\
42\end{array}$ & $\begin{array}{l}\text { I } \\
\text { I } \\
\text { wS }\end{array}$ & $\begin{array}{l}\text { Do. } \\
\text { Vermejo Park Corp. } \\
\text { Boy Scouts of America }\end{array}$ \\
\hline \multirow{3}{*}{${ }_{34}^{34}$} & \multirow{5}{*}{ 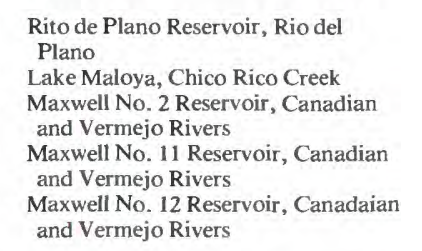 } & & & & & & \\
\hline & & $32 \mathrm{~N}$ & 24E. & $\begin{array}{ll}21 \\
27\end{array}$ & 114 & $\mathrm{R}, \mathrm{WS}$ & $\begin{array}{l}\text { Sabie rancheco. } \\
\text { City of Raton }\end{array}$ \\
\hline & & $27 \mathrm{~N}$. & $22 \mathrm{E}$ & 6 & 420 & $F C, \mathbf{l}, \mathbf{R}$ & Vermejo Conservancy District \\
\hline 35 & & $27 \mathrm{~N}$. & $22 \mathrm{E}$ & 16 & 126 & $F C, I, R$ & Do. \\
\hline & & $27 \mathrm{~N}$. & $22 \mathrm{E}$ & 22 & 335 & $F C, I, R$ & Do. \\
\hline \multirow[t]{3}{*}{36} & $\begin{array}{l}\text { Maxwell No. } 13 \text { Reservoir, Canadian } \\
\text { and Vermeje Rivers } \\
\text { Maxwell No }\end{array}$ & $27 \mathrm{~N}$. & $22 \mathrm{E}$ & 15 & 336 & $\mathrm{FC}, \mathrm{I}, \mathrm{R}$ & Do. \\
\hline & 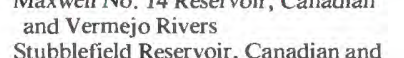 & $27 \mathrm{~N}$. & $22 \mathrm{E}$. & 11 & 170 & $\mathrm{FC}, \mathrm{I}, \mathrm{R}$ & Do. \\
\hline & 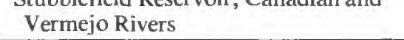 & $27 \mathrm{~N}$. & $21 \mathrm{E}$. & 13 & 1,150 & $\mathrm{FC}, \mathrm{I}, \mathrm{R}$ & Do. \\
\hline
\end{tabular}




\title{
Stream-Use Classifications Vary Between the Mountainous and Plains Regions
}

\author{
Use classifications for mountain streams require better water quality than \\ those for plains streams.
}

Stream segments have been classified for various uses in Area 61 (fig. 3.3-1). The mountain streams are classified for use as cold-water fisheries, for public water supplies, for primary- or secondarycontact recreation, and for agricultural use. Plains streams are classified for use as warm-water fisheries, for secondary-contact recreation, and for agricultural use. The classifications are intended to protect stream-water quality so that it is suitable for the indicated use.

In Colorado, the classifications were made by the Colorado Department of Health (1980). In New Mexico, the classifications were made by the New Mexico Water Quality Control Commission (1977). The use classifications shown in figure 3.3-1 have been generalized somewhat to account for differences in language between use classifications between the two States. Associated with each use classification are numerical water-quality standards for specific water-quality constituents.

The numerical standards for certain water-quality constituents may differ between the States for a given use classification. Because of different ambient water quality, the numerical standards also may differ from one stream segment to another classified for the same use within Colorado. The divisions shown in figure 3.3-1 between the upstream and downstream segments of some of the New Mexico streams are approximate. The divisions are based on the location where the stream changes from perennial to intermittent.

Many water-quality constituents may affect the suitability of water for a specific use. For fisheries, among the most important constituents are temperature; dissolved oxygen; $\mathrm{pH}$; many metals; some inorganic constituents, such as ammonia; and some pesticides which are toxic to fish. Water-quality constituents of concern in public water supplies are those which may have toxic effects, such as lead, selenium, or mercury; those which may cause gastrointestinal problems, such as sulfate, or other adverse physiologic effects, such as fluoride; those which may cause problems of taste or odor, such as large concentrations of dissolved solids; those which may cause corrosion of pipes, such as acidity; and those which may cause stains on laundry or porcelain, such as iron or manganese. Of primary concern in waters used for recreational purposes, such as swimming or boating, are fecal-coliform bacteria, which are used as an indicator of the presence of organisms which may cause disease when ingested. Waters intended for agricultural use, especially irrigation, commonly are judged for suitability on the basis of specific conductance or dissolvedsolids concentration in conjunction with the concentration of some other constituents, such as boron, which may be toxic to certain plants. 


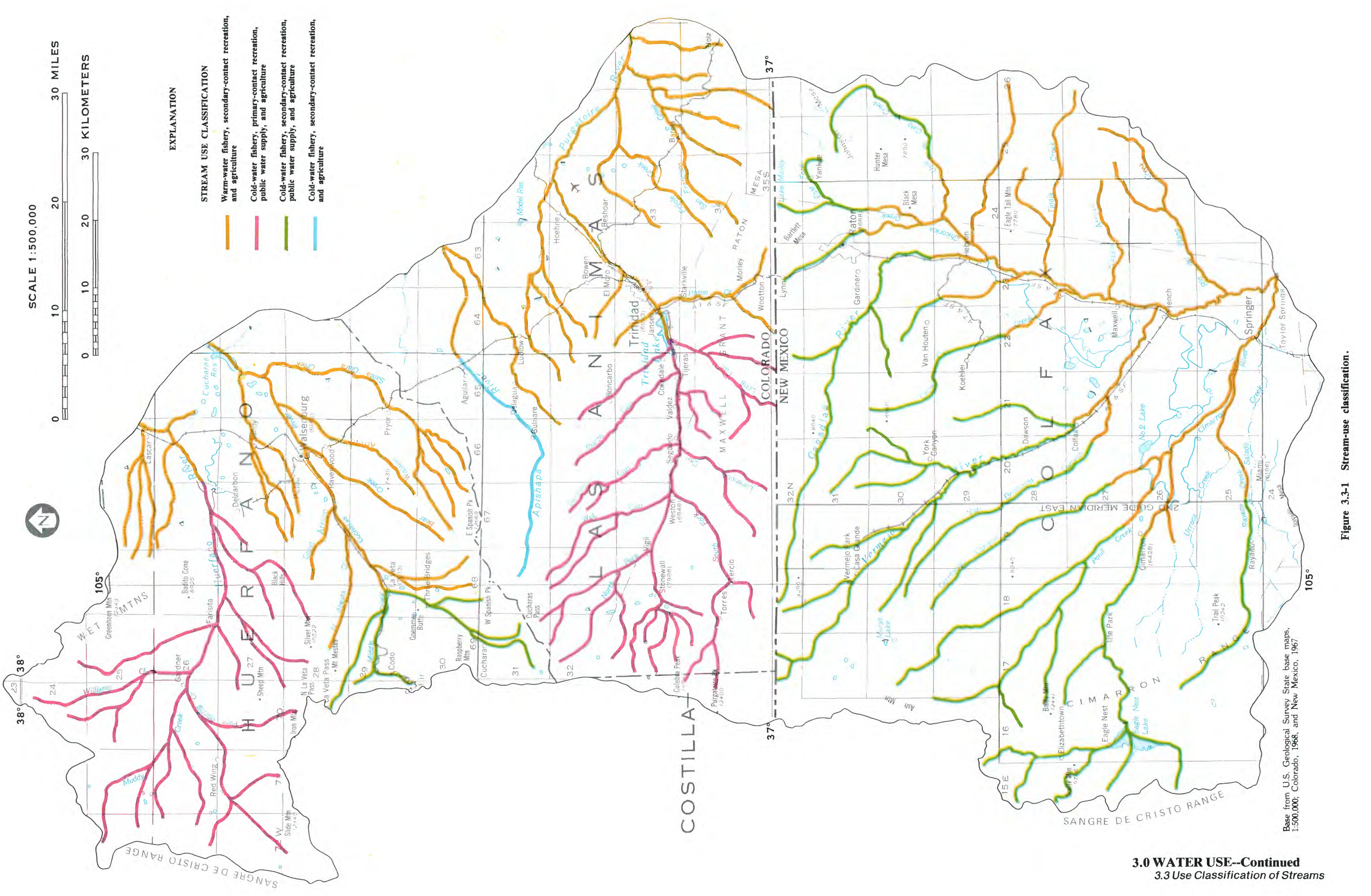




\title{
Streamflow Information is Available from 52 Locations, Water-Quality Information from 22 Locations, and Biological Information from 45 Locations
}

\author{
Information on surface water is available from 27 active streamflow-gaging \\ stations and 11 active water-quality stations.
}

Streamflow-discharge information presently (1982) is being collected at 27 locations in Area 61. In addition, there are 25 sites where data collection has been discontinued but information is available for various periods of record. The location of all 52 stations is shown in figure 4.1-1; a station description for each station is given in the "Supplemental Data" section of this report. The 52 streamflow-gaging stations consist of 44 that recorded continuous flow and 8 crest-stage gages that recorded only high stages of runoff associated with rainstorms or snowmelt.

Each streamflow station has been assigned an eight-digit number, such as 07124200 . The first two digits " 07 " refer to the major drainage and indicate that these stations are located in the Arkansas River basin. The remaining six digits index the station location relative to other stations in a basin; numbers increase in a downstream direction. For this report, a lesser map number has been assigned each station, as shown in the "Supplemental Data" section; this number is used in all illustrations.

Since water year 1961 the data have been published in the annual U.S. Geological Survey reports "Water Resources Data for Colorado" and "Water Resources Data for New Mexico." Compilations of records prior to 1970 also are available in U.S. Geological Survey Water-Supply Papers: WSP 1311--Compilation of Records of Surface Waters of the United States through September 1950, Part 7 (Lower Mississippi River basin). WSP 1731--Compilation of Records of Surface Waters of the United States, October 1950 to September 1960, Part 7
(Lower Mississippi River basin). WSP 1921--Surface-Water Supply of the United States, 1961-65, Part 7, Volume 2 (Arkansas River basin). WSP 2121--Surface-Water Supply of the United States, 1966-70, Part 7, Volume 2 (Arkansas River basin).

The first two publications listed are compilations of monthly records and the last two are compilations of daily records. The data also are available from computer storage through the National Water Data Exchange (NAWDEX).

Surface-water quality information presently (1982) is being collected at 11 locations in Area 61 . There are 11 additional locations where data have been collected in the past. The location of all 22 stations is shown in figure 4.1-1. A summary of the types of data available and the period of record is given in the "Supplemental Data" section. Much of the water-quality data available shows major anions and cations, but several sites also have data available for nutrients, metals, and suspended sediment. In addition to the surface-water quality stations shown in figure 4.1-1 where laboratory chemical- quality data are available, monthly measurements of specific conductance and water temperatures are made at many of the continuous-record discharge stations.

Between 1971 and 1980, biological data have been collected at 45 sites in Area 61. The location of all 45, all sites in Colorado, is shown in figure 4.1-1; a site description and period of record are given in the "Supplemental Data" section. 


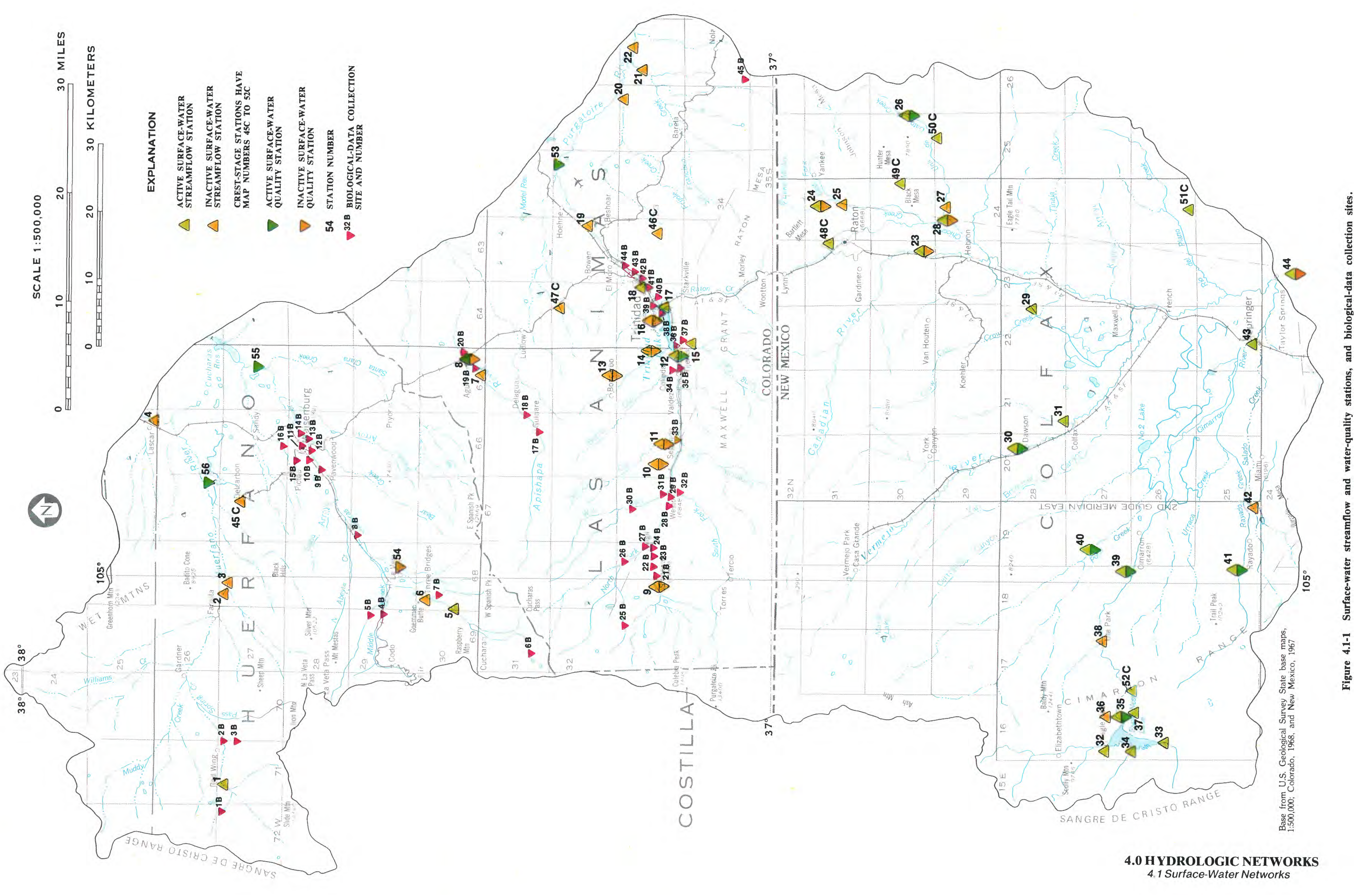




\subsection{HYDROLOGIC NETWORKS--Continued}

4.2 Ground-Water Networks

\section{The Data Base Includes 377 Sites}

\section{Observation-well networks monitored by the U.S. Geological Survey and private companies and inventories of wells, springs, and mines by the U.S. Geological Survey provide data for describing ground-water conditions in the area.}

The U.S. Geological Survey annually measures and records water levels in 13 observation wells in Huerfano and Las Animas Counties, Colo. Samples of water for chemical analyses have been collected from 10 of these wells. Seven additional wells, five of which were sampled, were formerly monitored for varying periods. In addition, many wells, springs, and mines were inventoried and sampled in Colorado (mostly north of the Purgatoire River) and in New Mexico (mostly east and south of the Park Plateau). Some of this information is published in Griggs (1948, p. 84-176), Powell (1952, p. 29-30), McLaughlin and others (1961), Dinwiddie (1964, p. 6-15), and Hart and Smith (1979), but much of it is unpublished U.S. Geological Survey data.

CF\&I Steel Corp. monitors water levels in nine observation wells at its Allen and Maxwell Mines near Weston, Colo. (Water, Waste, and Land, Ltd., 1980, and unpublished data). Samples of water for chemical analyses were collected from six of these wells. CF\&I also monitors the volume and quality of mine discharge at the two sites.

Kaiser Steel Corp. monitors water levels and quality in 16 observation wells, as well as the volume and quality of mine discharge, at its York Canyon Mine, west of Raton, N. Mex. (Dames and Moore, 1978, and unpublished data).

A data base of 377 sites was selected for this report on the basis of the spatial distribution of the sites and the quantity and quality of data available at each site. The data base includes wells and springs discharging from single bedrock and alluvial aquifers, multiple bedrock aquifers, and discharge from mines and tailings. Two hundred and five of these sites have water-quality analyses available. The data base is shown in figure 4.2-1. Representative ground-water data are included in the "Supplemental Data" section and data-site numbers in this report correspond to this tabulation.

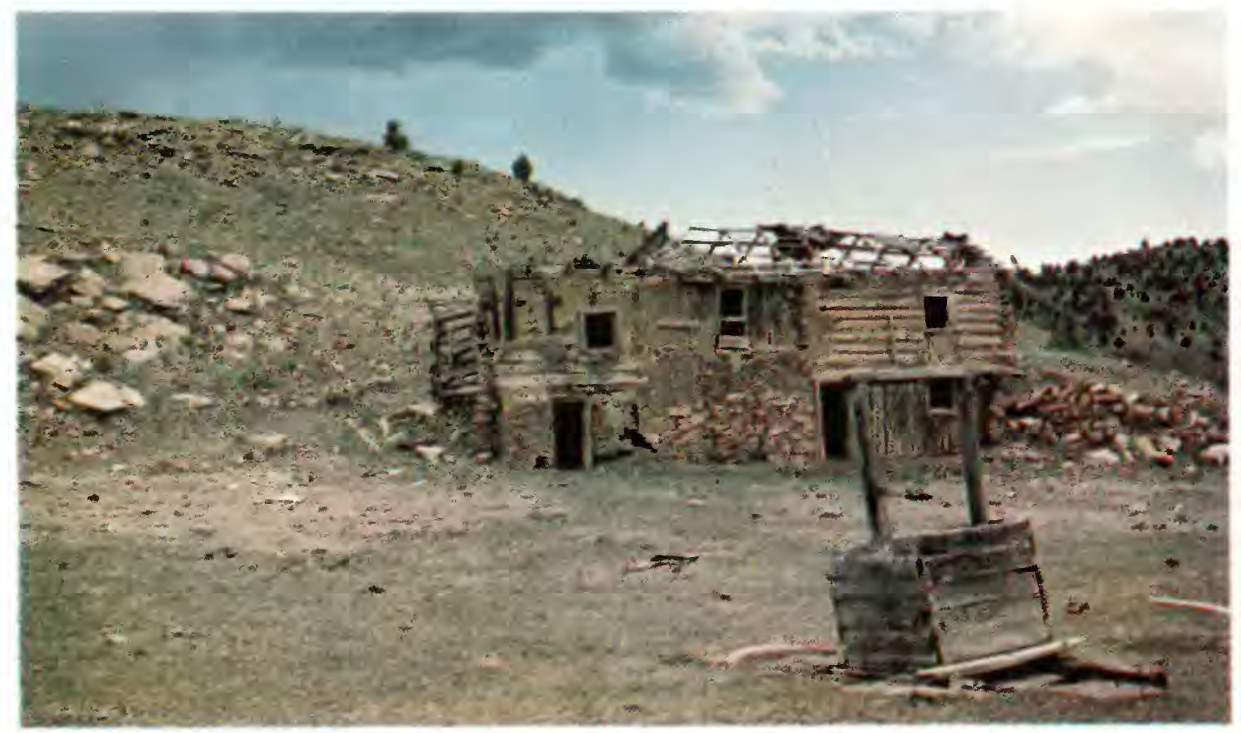

Figure 4.2-2 A well in Burro Canyon near Segundo, Colorado. 


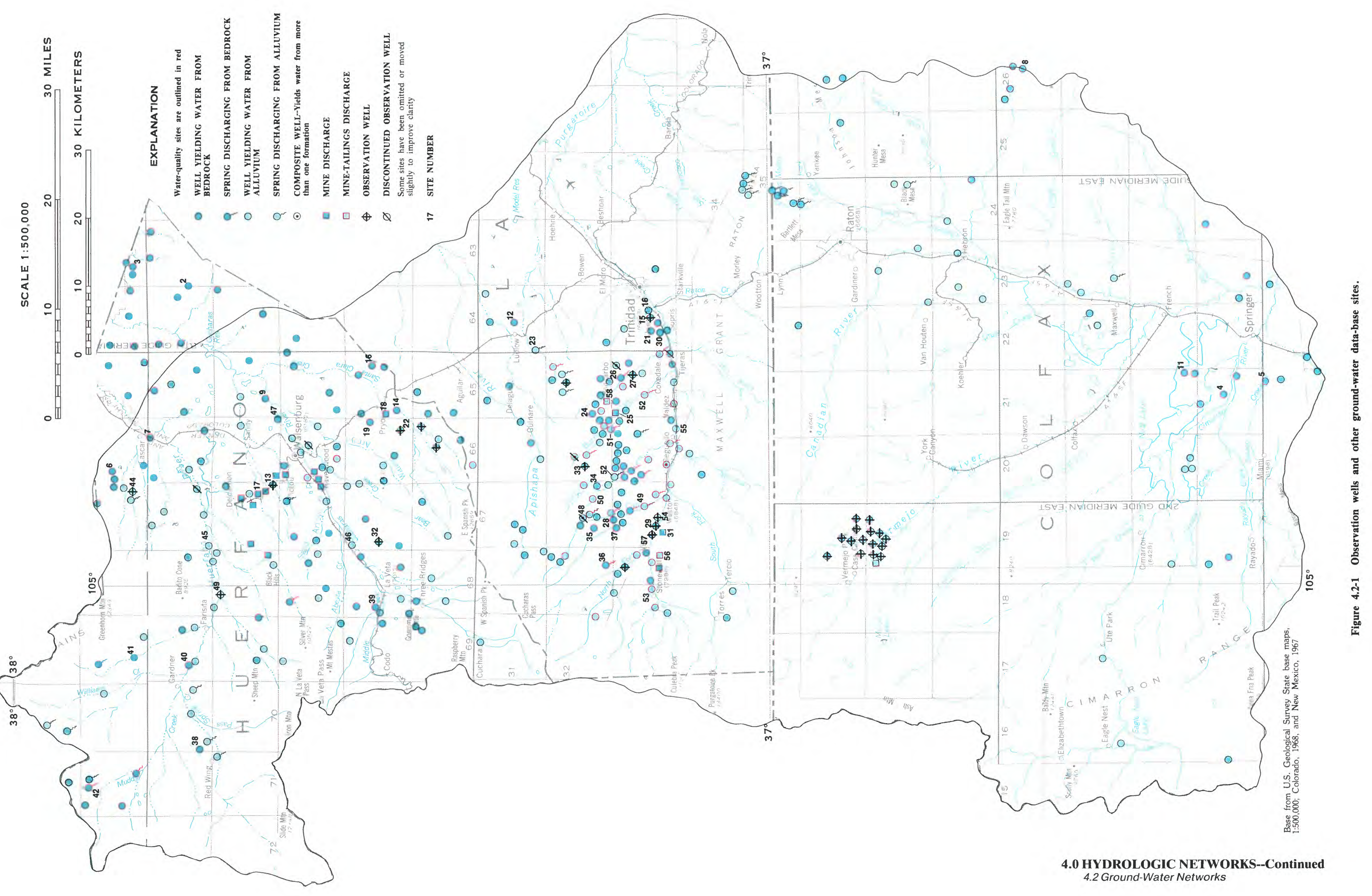




\title{
A Large Percentage of the Annual Runoff Occurs in Spring and Early Summer Months as Snowmelt from the Higher Elevations
}

\author{
In perennial streams in Area 61 the typical seasonal pattern of runoff is base \\ flow from late fall to early spring, a snowmelt peak in spring and early summer \\ months, and occasional to frequent rainfall peaks in the summer months.
}

The typical seasonal pattern of streamflow in Area 61 is shown by a representative hydrograph of mean daily discharge (fig. 5.1-1). The hydrograph illustrates mean daily flow of the Purgatoire River at Madrid, Colo., during water year 1979. Water year 1979, a year of greater-than-average flow, illustrates the phases of the annual runoff cycle. The flow in the river is virtually base flow from the first of October through the winter months. Beginning in late April to mid-May, snowmelt from the higher elevations of the Culebra Mountains to the west fills the channel with spring runoff. Typically, a large percentage of the annual runoff volume occurs in the spring and early summer months as snowmelt. The sharp peak flows in July, August, and September are from locally intense thunderstorms that occur in the region.

As is characteristic of other streams in the area, streamflow in the Purgatoire River is depleted by diversions and is regulated by reservoirs. Upstream from the Madrid gage are about 6,000 acres of irrigated lands and several small onchannel reservoirs.

Average and extreme discharges for the period of record at selected streamflow gages in Area 61 are listed in table 5.1-1. Average discharge is a somewhat misleading statistic for streams in this area because of the large seasonal variation in flow.
Predictive equations are available to estimate mean annual flow (Qa), in cubic feet per second for Colorado (Livingston, 1970) and for New Mexico (Borland, 1970). As these equations were developed on a statewide basis it is to be expected that they might be less applicable in some areas of the State than in others. The Colorado equation was developed using data predominantly for the mountains of central and northern Colorado. For Area 61, the equations developed for New Mexico, based on comparison of the methods using streamflow-gaging station records from the area, are more applicable. That equation:

$$
\mathrm{Qa}=3.24 \times 10^{-5} \mathrm{~A}^{1.01} \mathrm{~S}^{0.448} \mathrm{~Pa}^{2.51} \mathrm{LA}^{0.537},
$$

has a standard error of estimate of 53 percent. The significant variables are drainage area $(A)$ in square miles, main channel slope $(S)$ in feet per mile, which is the average slope between points 10 and 85 percent of the distance from the site of interest and the drainage divide, the mean October through April precipitation $(\mathrm{Pa}$ ) in inches (from fig. 5.1-2), and the latitude at the center of the drainage basin (LA) in degrees minus 30 . The above equation is for perennial (flowing year around) streams only. No equation exists for streams that are dry for a part of the year. 
Table 5.1-1 Average and extreme discharges at selected streamflow-gaging stations in Area 61.

\begin{tabular}{|c|c|c|c|c|c|}
\hline \multirow[b]{2}{*}{$\begin{array}{l}\text { Map } \\
\text { No. }\end{array}$} & \multirow[b]{2}{*}{$\begin{array}{l}\text { Streamflow-gaging station } \\
\text { (U.S. Geological Survey No.) } \\
\end{array}$} & \multicolumn{2}{|c|}{ Average discharge } & \multicolumn{2}{|c|}{$\begin{array}{l}\text { Extremes for period } \\
\text { of record }\end{array}$} \\
\hline & & $\begin{array}{l}\text { Years of } \\
\text { record }\end{array}$ & Discharge & $\begin{array}{l}\text { Instantaneous } \\
\text { maximum }\end{array}$ & $\underset{\text { daily }}{\text { Minimun }}$ \\
\hline 1 & $\begin{array}{l}\text { Huerfano River at Manzanares } \\
\text { Crossing near Redwing, Colo. } \\
(07111000)\end{array}$ & 56 & 31.3 & 10,200 & 3.5 \\
\hline 5 & $\begin{array}{l}\text { Cucharas River at Boyd Ranch, } \\
\text { near La Veta, Colo. } \\
(07114000)\end{array}$ & 46 & 22.5 & 444 & 2.0 \\
\hline 12 & $\begin{array}{l}\text { Purgatoire River at Madrid, } \\
\text { Colo. }(07124200)\end{array}$ & 8 & 53.0 & 14,300 & 3.0 \\
\hline 23 & $\begin{array}{l}\text { Canadian River near Hebron, } \\
\text { N. Mex. (07199000) }\end{array}$ & 33 & 7.06 & 62,400 & 0 \\
\hline 30 & $\begin{array}{l}\text { Vermejo River near Dawson, } \\
\text { N. Mex. }(07203000)\end{array}$ & 55 & 17.9 & 12,600 & 0 \\
\hline 39 & $\begin{array}{l}\text { Cimarron River near Cimarron, } \\
\text { N. Mex. }(07207000)\end{array}$ & 29 & 20.6 & 15,500 & 0 \\
\hline
\end{tabular}

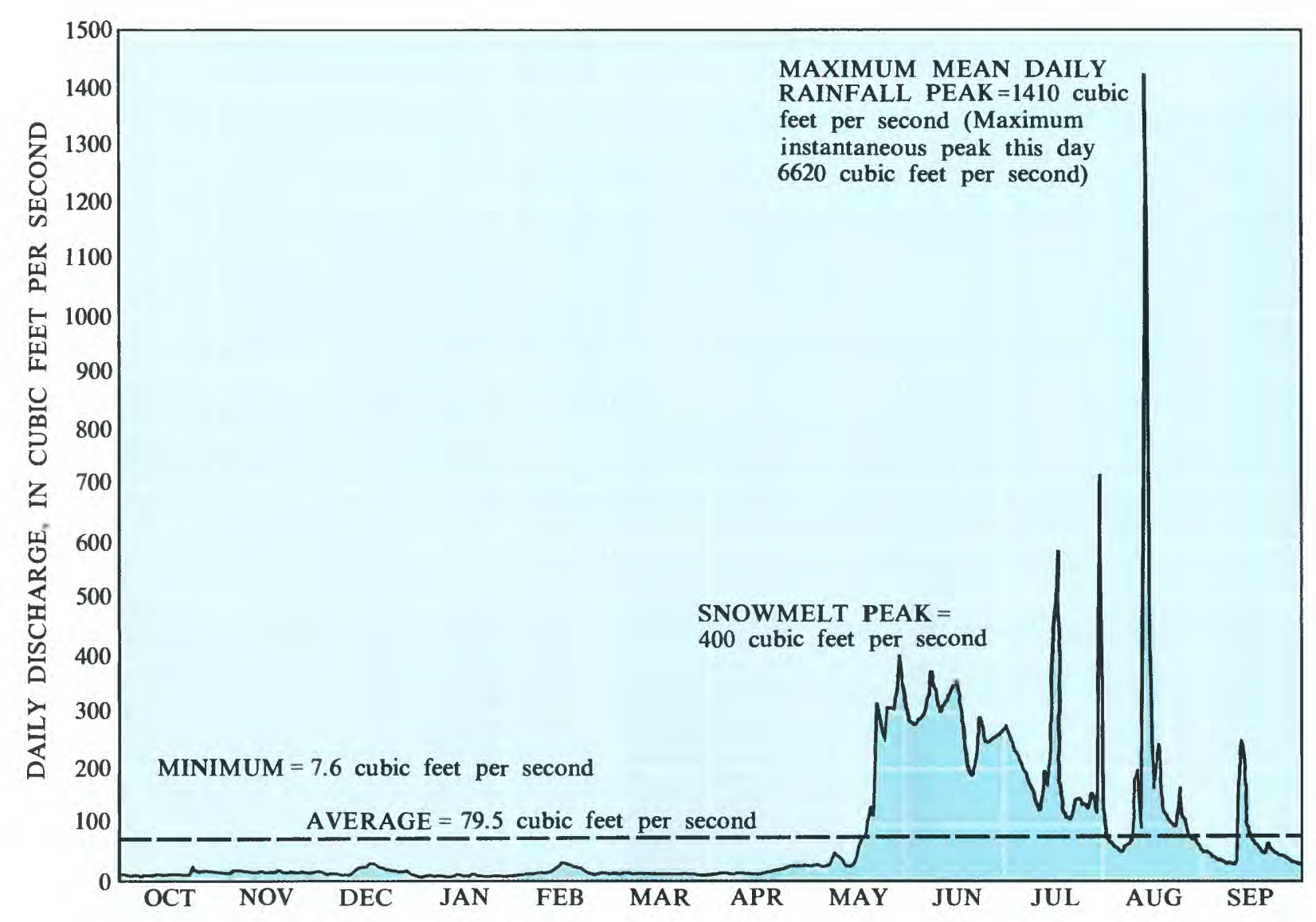

Figure 5.1-1 Mean daily flow, Purgatoire River at Madrid, Colorado,

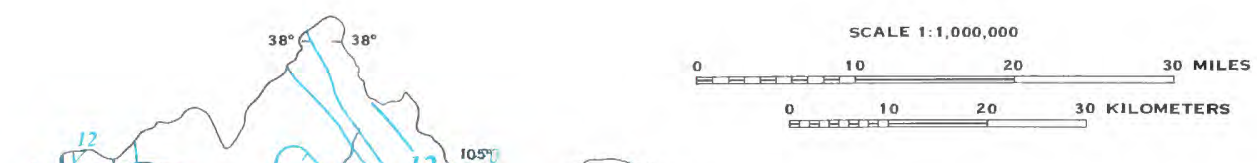

EXPLANATION

\section{${ }^{39}$ STREAMFLOW-GAGING STATION \\ -20- LINE OF EQUAL OCTOBER THROUGH
APRIL PRECIPITATION-Interval, in inches is variable}

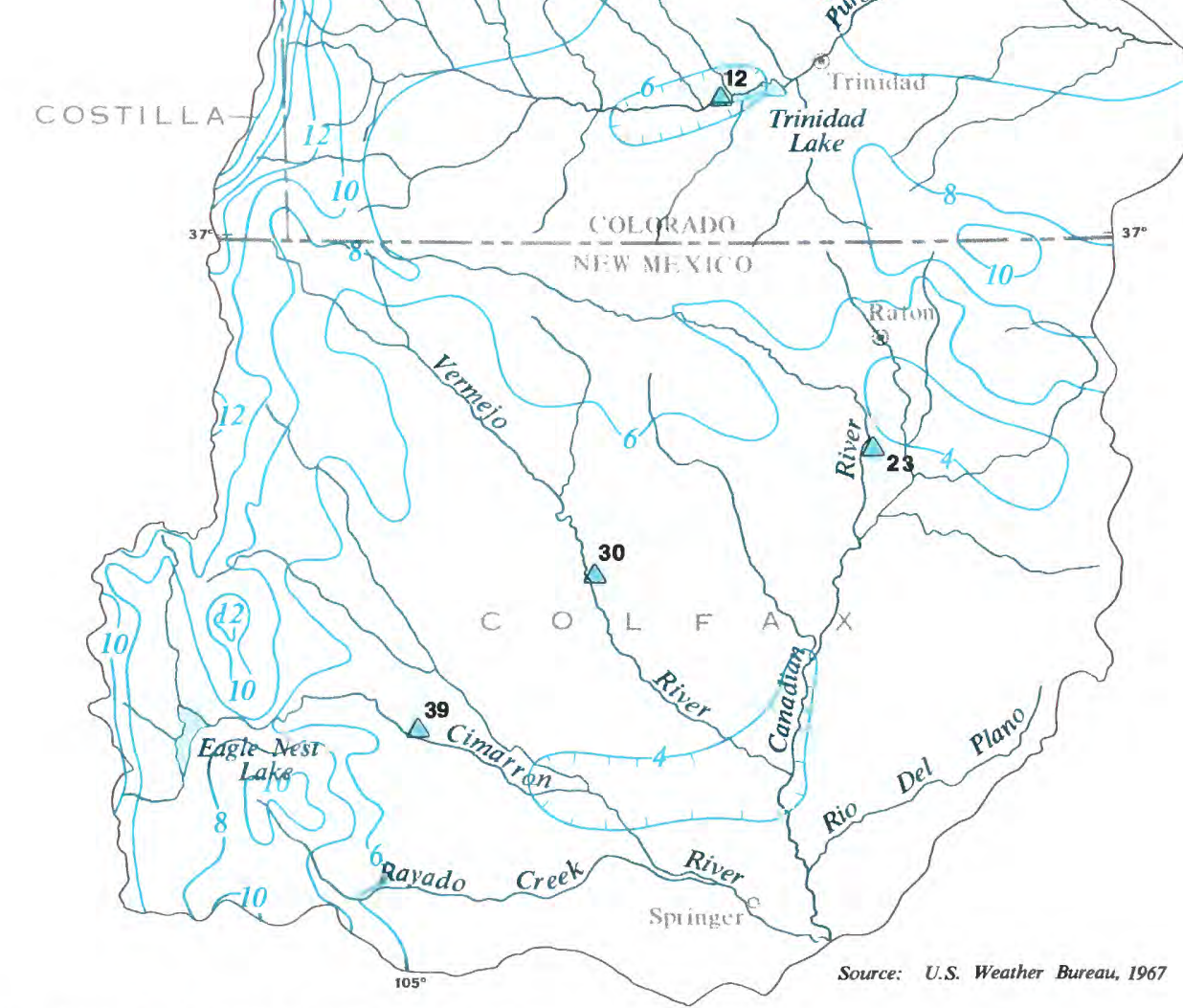

Base from U.S. Geological Survey State base maps
1:500,000; Colorado, 1968 , and New Mexico, 1967 Figure 5.1-2 Normal October through April precipitation and location 


\section{A Frequency Curve Relates Magnitude of a Variable to the Frequency of Occurrence}

\section{Frequency curves are used to estimate the probability that a particular minimum or maximum streamflow will occur in any future year.}

Frequency curves can be developed from available recorded streamflow data. Low-flow frequency information can be used to evaluate a stream's adequacy to supply water for various uses such as municipal supplies, industrial supplies, irrigation supplies, waste dilution, and wildlife conservation. Information on a stream's high-flow characteristics is useful in the design of dams, reservoirs, and flood-control and navigation channels.

Low-flow and high-flow frequency for the Purgatoire River at Trinidad, Colo., for the period of record, is illustrated in figure 5.2-1. Families of curves are shown for low flows of 3-, 7-, 14-, and 30-day mean discharges and for high flows of 3-, 4-, 15-, and 30-day means.

Low-flow frequencies and high-flow frequencies for selected streamflow-gaging stations in Area 61 are listed in table 5.2-1. Flows at these stations are considered to be representative of flows of perennial streams in the area. Location of the streamflow gages is shown on the accompanying map. 
PRoBabutr

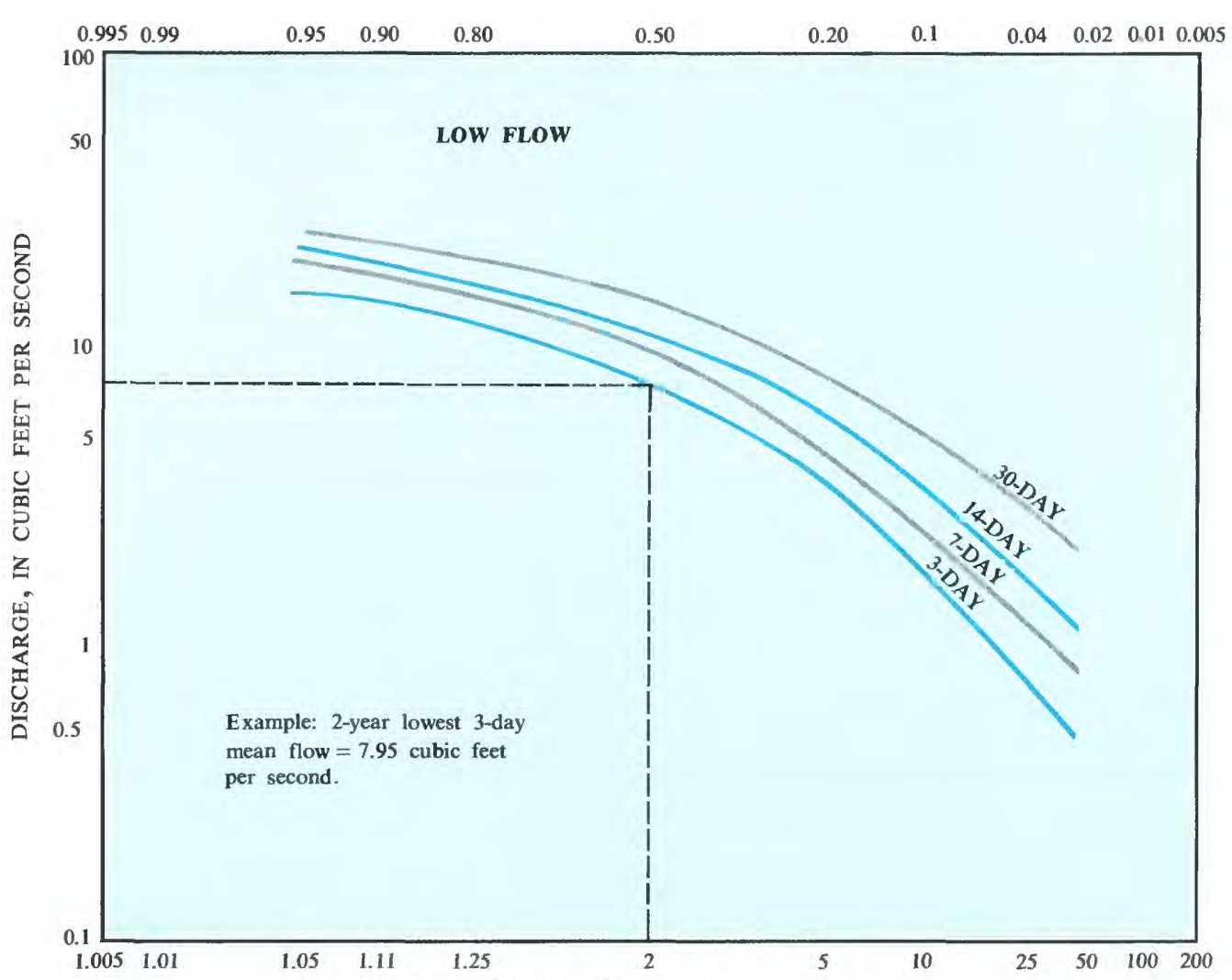

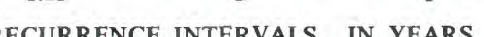
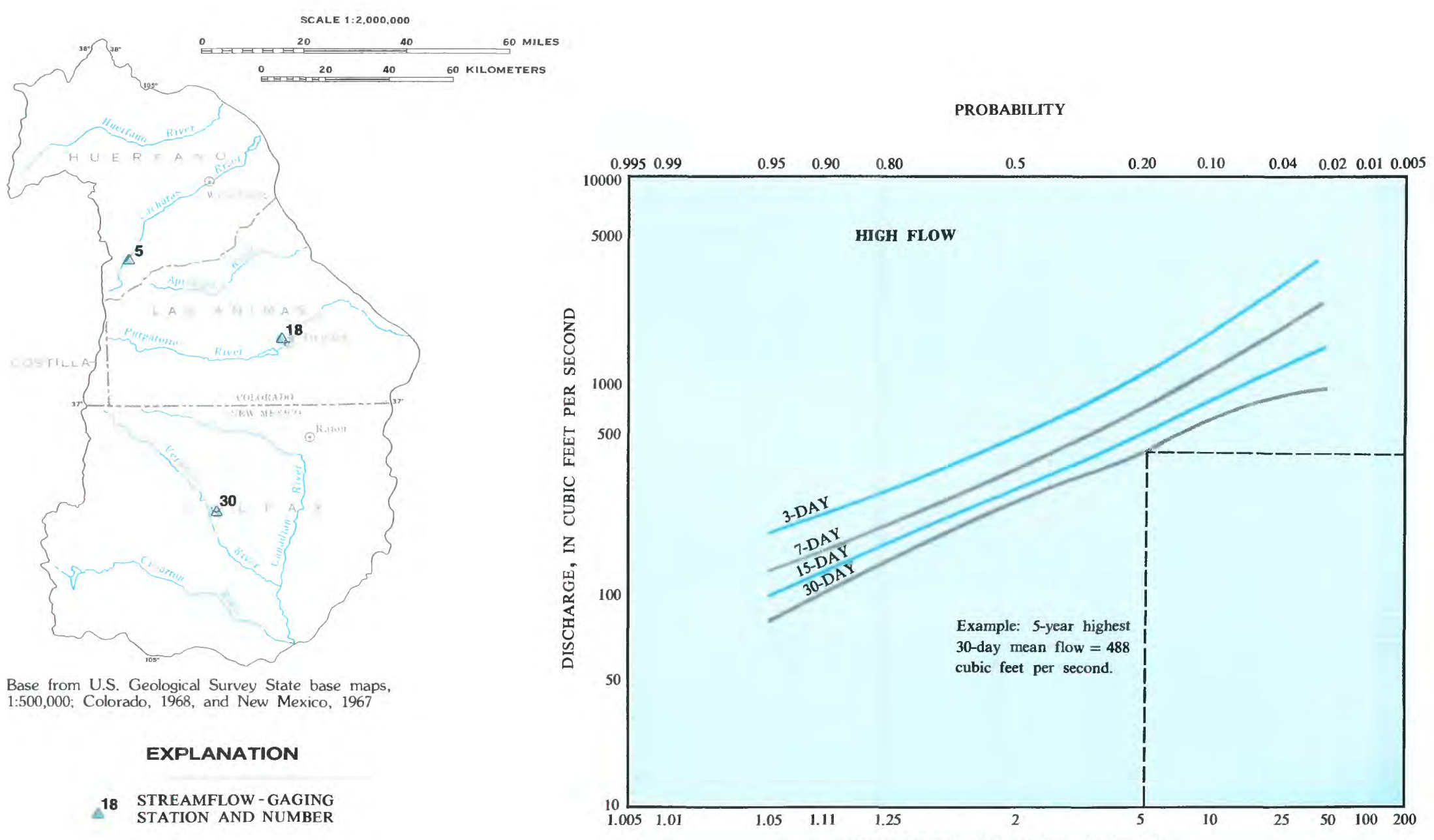

RECURRENCE INTERVAIS, IN YEARS

Figure 5.2-1 Low-flow and high-flow frequency curves for station 18, Purgatoire River, at Trinidad, Colorado

Table 5.2-1 Low-now and high-nlow frequencies for selected streamnlow-gaging stations in Area 61.

\begin{tabular}{|c|c|c|c|c|c|c|c|c|c|c|c|c|c|c|c|c|c|c|c|}
\hline \multirow{3}{*}{$\begin{array}{l}\text { Map } \\
\text { No. }{ }^{1}\end{array}$} & \multirow{3}{*}{$\begin{array}{c}\text { Streamflow- } \\
\text { gaging station } \\
\text { (U.S. Geological } \\
\text { Survey No.) } \\
\end{array}$} & \multirow{3}{*}{$\begin{array}{l}\text { Period of } \\
\text { record }^{2}\end{array}$} & \multirow{3}{*}{$\begin{array}{c}\text { Drainage } \\
\text { area } \\
\text { (square } \\
\text { miles) } \\
\end{array}$} & \multicolumn{8}{|c|}{$\begin{array}{l}\text { Lowest average discharge for recurrence interval } \\
\text { shown for indicated period of consecutive days }\end{array}$} & \multicolumn{8}{|c|}{$\begin{array}{l}\text { Highest average discharge for recurrence interval } \\
\text { shown for indicated period of consecutive days }\end{array}$} \\
\hline & & & & \multicolumn{4}{|c|}{2 years } & \multicolumn{4}{|c|}{5 years } & \multicolumn{4}{|c|}{2 years } & \multicolumn{4}{|c|}{5 years } \\
\hline & & & & 3 & 7 & 14 & 30 & 3 & 7 & 14 & 30 & 3 & 7 & 15 & 30 & 3 & 7 & 15 & 30 \\
\hline 5 & $\begin{array}{l}\text { Cucharas River at } \\
\text { Boyd Ranch, near } \\
\text { La Veta, Colo. } \\
\text { (07114000) }\end{array}$ & $1935-80$ & 56.0 & 5.01 & 5.51 & 5.80 & 6.26 & 3.904 & 4.35 & 4.635 & 5.00 & 98.3 & 91.7 & 83.0 & 74.0 & 197 & 180 & 161 & 143 \\
\hline 18 & $\begin{array}{l}\text { Purgatoire River at } \\
\text { Trinidad, Colo. } \\
(07124500)\end{array}$ & $\begin{array}{l}\text { 1898-99, } \\
1911-12 \\
1917-60 \\
1963-80\end{array}$ & 795 & 7.95 & 9.48 & 11.9 & 14.3 & 3.494 & 4.32 & 5.937 & 7.96 & 572 & 416 & 333 & 273 & 1,190 & 814 & 613 & 488 \\
\hline 30 & $\begin{array}{l}\text { Vermejo River near } \\
\text { Dawson, N. Mex. } \\
\text { (07203000) }\end{array}$ & $\begin{array}{l}1916-17 \\
1920 \\
1928-80\end{array}$ & 301 & .914 & 1.11 & 1.46 & 2.16 & .391 & .480 & .512 & 2.806 & 141 & 98.7 & 75.4 & 58.7 & 298 & 203 & 150 & 115 \\
\hline
\end{tabular}

${ }^{1}$ Refers to listing in "Supplemental Data" and locations shown in figure 5.2-1.

${ }^{2}$ Refers to record, in water years (October 1 to September 30 ), from which characteristics were determined; records may exist for other periods. 


\title{
5.0 SURFACE WATER--Continued \\ 5.3 Duration of Flow
}

\section{Time Distribution of Streamflow Is Illustrated by the Flow-Duration Curve}

\author{
Flows in streams draining foothill areas are poorly sustained in comparison \\ with those draining the mountain environment.
}

The time distribution of streamflow is illustrated by the flow-duration curve. Five streamflow-gaging stations were selected to illustrate the diversity of flow characteristics within Area 61. The five streamflow-gaging stations are shown in figure 5.3-1, and their respective flow-duration curves are shown in figure 5.3-2. Flow-duration curves show the percentage of time that a specific discharge was equaled or exceeded during a given time. All flow-duration curves shown in figure 5.3-2 represent the period of record for each station with one exception. The flow-duration curve for streamflow-gaging station 18 (fig. 5.3-1) is for the period prior to 1976 when construction of Trinidad Dam was completed.

A flow-duration curve with a consistent steep slope indicates variable streamflow resulting from direct surface runoff or upstream diversions (Livingston and others, 1976). Both conditions exist for the Canadian River near Hebron at station 23. A flowduration curve having a flatter slope, especially at the lower end, indicates streamflow from delayed surface runoff and ground-water storage. Streamflow- gaging stations $5,18,30$, and 40 (fig. 5.3-1) are in this category. (Note that stations 18,30, and 40 have steeper slopes at the lower end than station 5, as shown in fig. 5.3-2.) Station 5 is affected by fewer upstream diversions than the other three stations and is nearer to the headwaters.

Mountain areas above 10,000 feet contribute delayed runoff from snowmelt during a normal season (fig. 5.3-1). Stations 18,30 , and 40 , which are affected by snowmelt and are sustained by water from the Raton Formation during low-flow periods, have similar duration curves (fig. 5.3-2).

At station 5, the flow is sustained because the station is located in the headwater area of the $\mathrm{Cu}$ charas River where precipitation is greatest. Station 20 on the Canadian River is poorly sustained because the basin is at a lower altitude and receives less precipitation in the form of snow; also, water is diverted for irrigation during the growing season. 

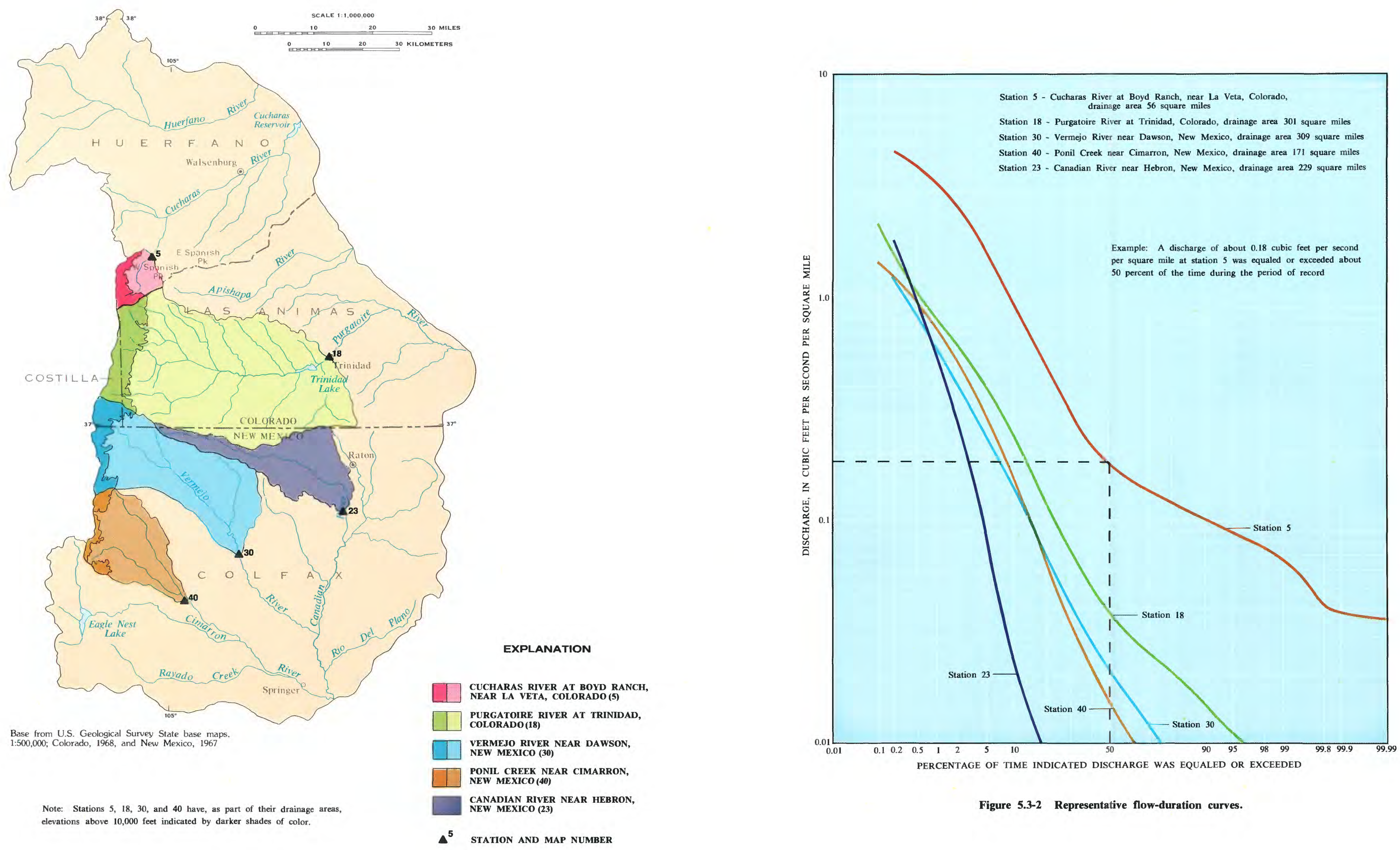

PERCENTAGE OF TIME INDTCATED DSCHARGE WAS EQUADIO OR EXCERDED

Figure 5.3-2 Representative flow-duration curves. 


\subsection{SURFACE WATER--Continued \\ 5.4 Flood Flow \\ 5.4.1 Floods}

\section{Flash Flooding Is a Problem}

\section{Floods result from intense thunderstorms during April through August and may cause considerable damage and loss of life.}

Thunderstorms produce floods generally during April through August when prevailing winds from the southeast bring moisture-laden air masses up against the mountains. East-trending highlands such as the Raton Mesa cause localized orographic lifting, resulting in floods such as those in May 1955 and June 1965. These storms have been described in U.S. Geological Survey Water-Supply Papers, "Floods of May 1955 in Colorado and New Mexico" (Vaudrey, 1960) and "Floods of June 1965 in the Arkansas River basin, Colorado, Kansas, and New Mexico" (Snipes and others, 1974). The greatest rainfall recorded during the 1955 storm was 13.59 inches in 48 hours at Lake Maloya, N. Mex.

A storm cell was located immediately west of Raton, N. Mex., in June 1965 (fig. 5.4.1-1). At the airport in Raton, N. Mex., on June 17, 1965, 5.52 inches of rainfall was recorded between 1700 and 2200 hours; 2.32 inches of this fell between 1900 and 2000 hours. The total rainfall during this storm was more than 10 inches (fig. 5.4.1-2). A rapid response in flood discharge of the Canadian River at Hebron, N. Mex. (fig. 5.4.1-2), resulted from each additional increment of rainfall at Raton.

Methods of estimating flood frequencies for basins in the area vary according to the size of the basin and the type of available information upon which the estimation is to be based. Equations for estimating the flood frequency of small ( 0.5 to 15 square miles) ungaged sites on unregulated streams in the Arkansas River basin in Colorado are described by Livingston (1981). For larger ungaged drainage basins and for regionalization of gaged basins in Colorado, methods are described by McCain and Jarrett (1976). Techniques for estimating flood discharges for unregulated streams in New Mexico are described by Thomas and Gold (1982).

The equations for estimating flood magnitudes for return intervals of 10 years $\left(Q_{10}\right), 50$ years $\left(Q_{50}\right)$, and 100 years $\left(Q_{100}\right)$ are presented below for the various methods. The equations developed by Livingston (1981) for small streams in Colorado are:

Standard error of estimate,

Equation in percent

$\begin{array}{ll}\mathrm{Q}_{10}=525 \mathrm{AE}^{0.68} & 47 \\ \mathrm{Q}_{50}=1,280 \mathrm{AE}^{0.77} & 40 \\ \mathrm{Q}_{100}=1,680 \mathrm{AE}^{0.82} & 37\end{array}$

where $\mathrm{AE}$ is the effective drainage area, in square miles.
The regionalized equations for larger streams in Colorado developed by McCain and Jarrett (1976) are:

Standard error of estimate, in percent

Equation

31
24
28

where A is total area of the drainage basin contributing to flood discharges, in square miles, and SB is basin (channel) slope, in feet per mile, measured between two points along the main channel--one of which is located at 10 percent of the channel length and the other at 85 percent of the channel length from the site of interest to the basin divide.

The equations developed by Thomas and Gold (1982) for streams in New Mexico are:

Standard error of estimate,

Equation in percent

where $\mathrm{A}$ is the contributing drainage area, in square miles, and $\mathrm{Sa}$ is site elevation, in feet above sea level.

As all the above equations were developed by regression analysis for hydrophysiographic regions using data from sites for the respective states under study, it is not surprising that the equations developed are not precisely applicable to an area such as Area 61 located north and south of the State boundary. It has been determined that a mean of the results of equations developed for Colorado and those developed for New Mexico give reasonable peak flow values for Area 61. For areas 15 square miles and smaller in size, an average of the Livingston equation results and the Thomas and Gold equation results needs to be used. For areas larger than 15 square miles, the average of the values computed by the McCain and Jarrett equation and by the Thomas and Gold equation needs to be used. The standard error of estimate probably is somewhere between the values given for each set of equations of a specified recurrence interval. 


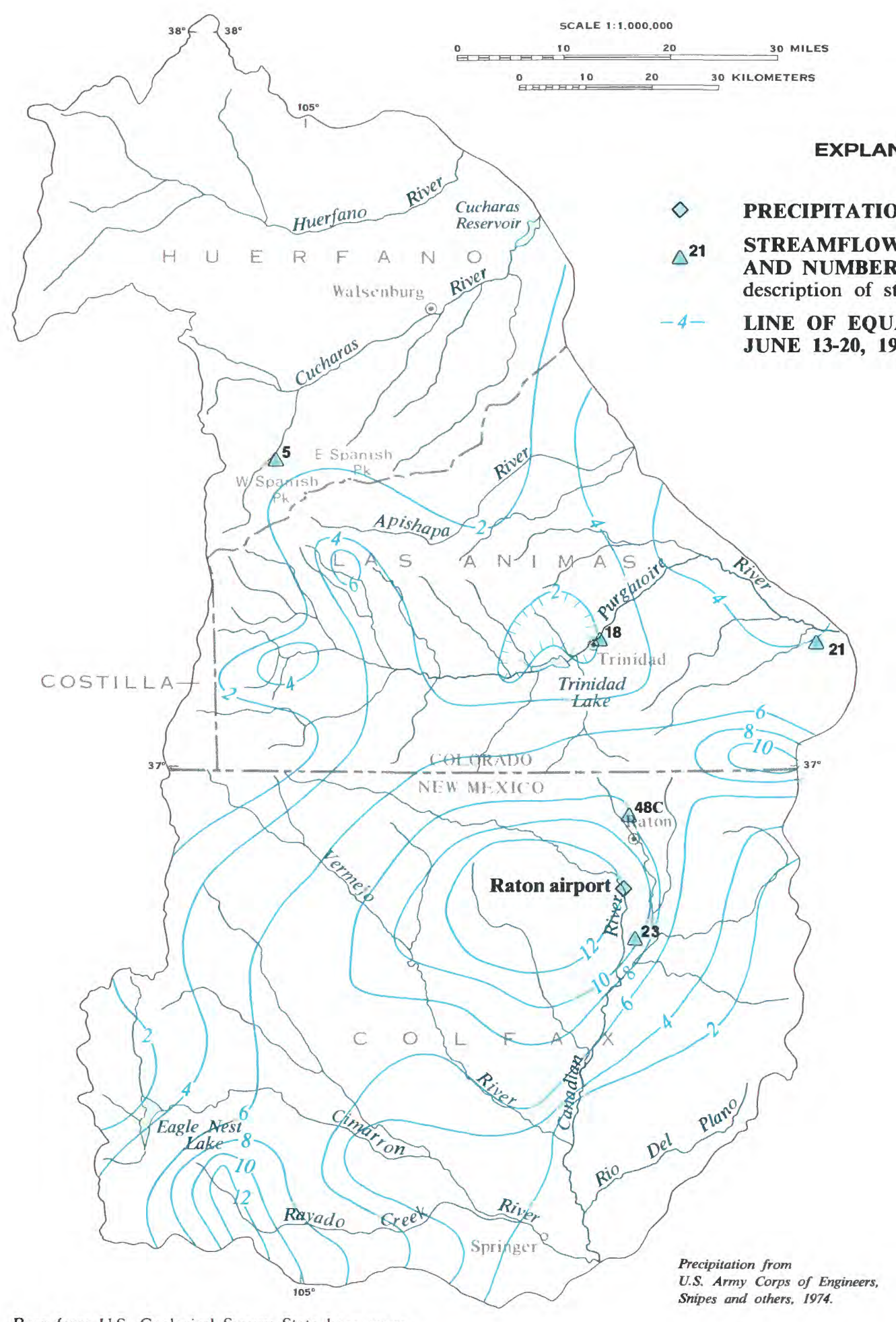

Base from U.S. Geological Survey State base maps
1:50,000; Colorado, 1968 , and New Mexico, 1967 ?

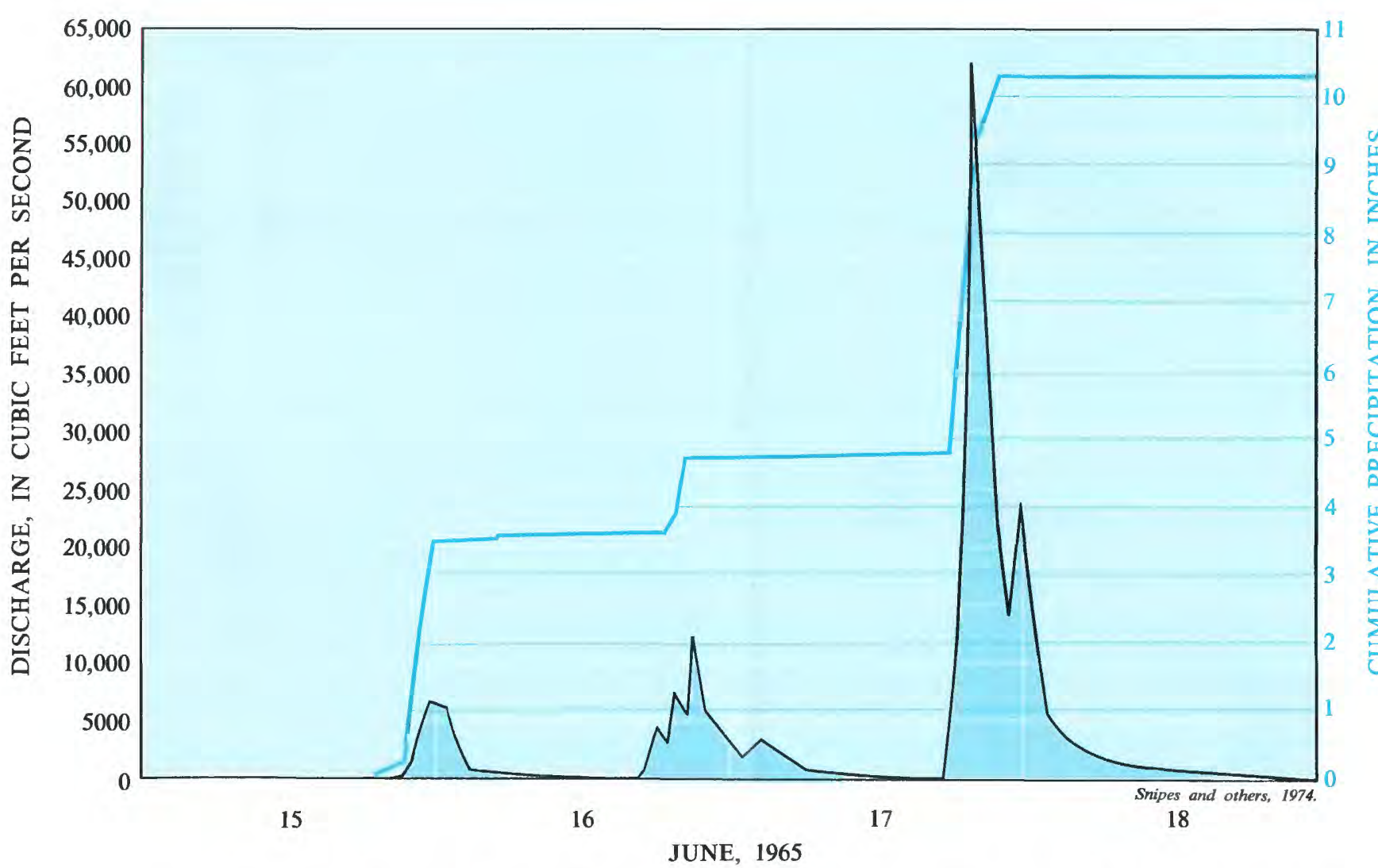

Figure 5.4.1-2 Flood of June 15-18, 1965, at Canadian River near Hebron, New Mexico, cumulative precipitation at airport in Raton, New Mexico, Canadian River basin, June 15-18, 1965.

Figure 5.4.1-1 Precipitation of June 13-20, 1965. 


\title{
5.0 SURFACE WATER--Continued \\ 5.4 Flood Flow--Continued \\ 5.4.2 Flood-Prone Area Mapping
}

\section{Topographic Mapping of Flood-Prone Areas is Available from the U.S. Geological Survey and Other Sources}

\author{
The extent of areas that would be inundated by a flood having a 100-year \\ recurrence interval has been mapped for use in flood-plain management plans.
}

Areas that would be inundated by a flood with a 100-year recurrence interval have been defined on U.S. Geological Survey topographic maps. Those topographic quadrangles in Area 61 with completed flood-prone area mapping are shown in figure 5.4.2-1.

Flood-hazard studies have been conducted in many communities throughout the Nation as a result of the National Flood Insurance Program (42 U.S.C. 4001-4128). Communities in Area 61 that have Federal Insurance Administration flood maps delineating the special flood-hazard areas of the community are listed in table 5.4.2-1. These maps may be ordered from National Flood Insurance Program, P.O. Box 34294, Bethesda, MD 20034. The unincorporated areas of Huerfano and Las Animas Counties, Colo., and Colfax County, N. Mex., also have been mapped through the Federal Insurance Administration program.

Prior to preparation of many Federal Insurance Administration flood maps, a flood-plain information study was conducted by a contractor, either Federal or private, at the request of the governing body of the community. These studies contain much more information than do the Federal Insurance Administration flood maps. These reports are usually available from, or are available for inspection in, the offices of the entity requesting the study. Copies of the reports also are available for inspection in many area libraries. Flood-plain information studies for communities within Area 61 are listed in the "Topical List of Selected References."

Table 5.4.2-1 Communities in Area 61 where flood-prone-area mapping is available.

[Federal Emergency Management Agency, 1981]

\begin{tabular}{llcl}
\hline Map & & Map \\
No. & Community & No. & Community \\
\hline & & & \\
& Colorado & & New Mexico \\
1 & La Veta, Town of & 6 & Cimarron, Village of \\
2 & Trinidad, City of & 7 & Raton, City of \\
3 & Walsenburg, City of & 8 & Springer, Town of \\
4 & Aguilar, Town of & 9 & Eagle Nest, Village of \\
5 & Starkville, Town of & 10 & Maxwell, Village of \\
\hline
\end{tabular}




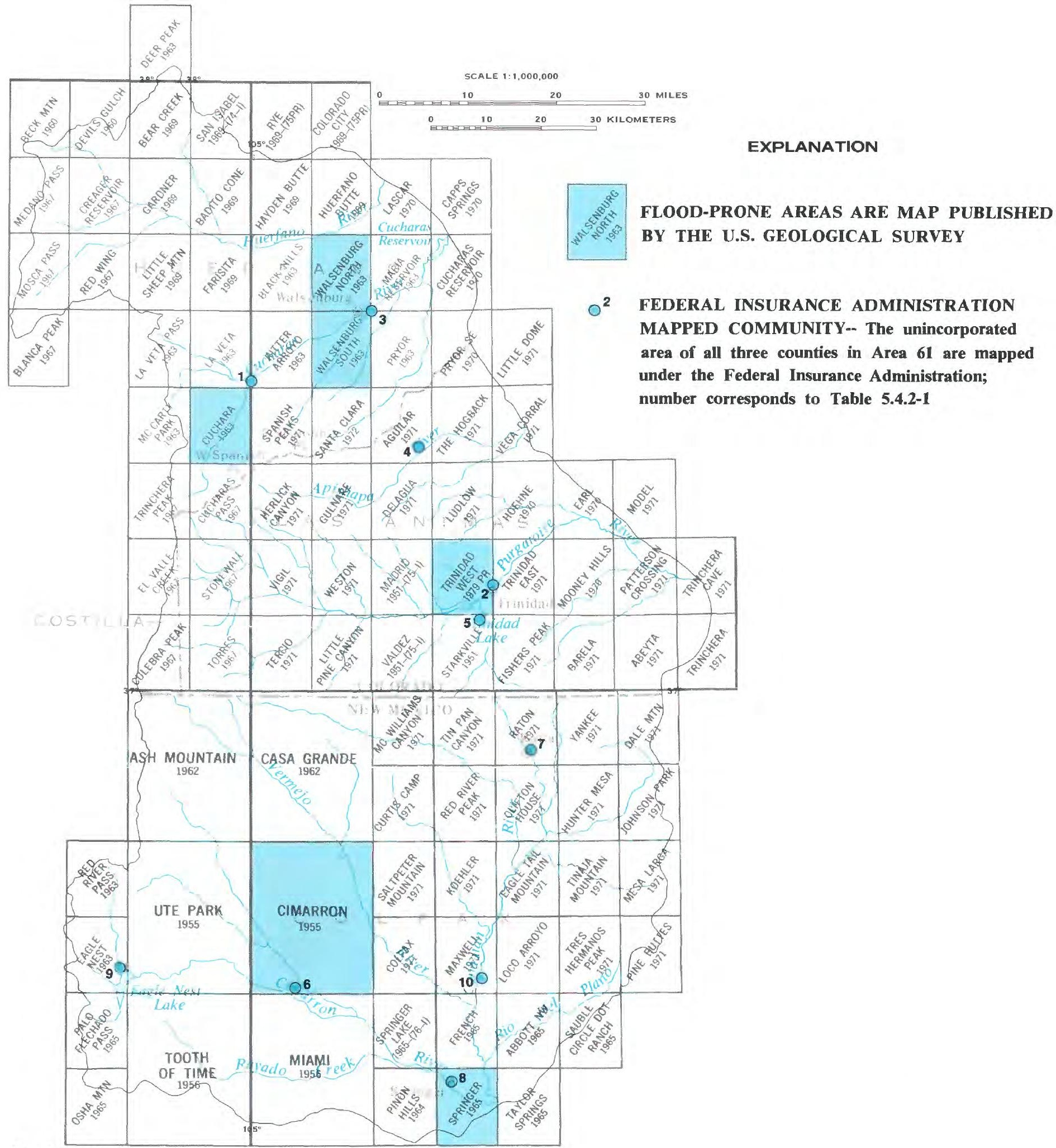

Base from U.S. Geological Survey State base maps, 1:500,000; Colorado, 1968, and New Mexico, 1967

Figure 5.4.2-1 Location of U.S. Geological Survey-mapped flood-prone-areas and communities with Federal Insurance Administration flood maps. 


\author{
6.0 SURFACE-WATER QUALITY \\ 6.1 Specific Conductance \\ 6.1.1 Downstream Changes
}

\title{
Specific Conductance of Streamflow Increases Downstream
}

\author{
Downstream increases in specific conductance result from variations in \\ precipitation, land and water use, and geology.
}

\begin{abstract}
Specific conductance of streamflow increases by at least a factor of 10 from the headwaters to the point where the stream leaves the area. Some of the increase is due to natural processes such as decreasing precipitation downstream and changes in bedrock geology. Most of the increase is related to man's use of the water for agricultural and, to a lesser extent, municipal purposes.
\end{abstract}

Specific conductance is a measure of the ability of water to conduct an electrical current and is expressed in micromhos per centimeter at $25^{\circ}$ Celsius. Specific conductance is a useful indicator of water quality because it is simple and inexpensive to measure and is directly related to the concentration of dissolved constituents.

Average specific conductance at stream sites is shown in figure 6.1.1-1. The average specific conductance was determined using all available data at each site. Specific conductance of streamflow is least in the mountainous and mesa areas and increases significantly in the plains areas because of changes in geologic, climatic, and land and water-use conditions. For example, at the headwaters of the Purgatoire River, bedrock consists of igneous and metamorphic rocks resistant to chemical weathering and less resistant sedimentary rocks (fig. 6.1.1-2). Chemical weathering results in dissolution of rock materials and release of dissolved constituents to the water. The headwaters area is primarily forest land and receives the greatest precipitation in the basin. This precipitation and resulting runoff accompanied by slow rates of chemical weathering results in water with an average specific conductance of 295 micromhos per centimeter at $25^{\circ}$ Celsius at Stonewall, Colo. The foothills area between Stonewall and Trinidad is used primarily for grazing and receives less precipitation. Bedrock geology in this area is dominated by the Raton and Poison Canyon Formations, which are more susceptible to chemical weathering. As a result, tributaries in this reach generally contribute water with greater specific conductance than the Purgatoire River. Some small mine drainages and seeps in this reach also contribute water with greater specific conductance. Because there is less precipitation in the foothills area, the contributions of water and dissolved constituents are small, and only a small increase in specific conductance occurs.

Downstream from Trinidad the valley opens onto the plains formed on more easily erodible and chemically weathered Cretaceous rocks. The flat terrain allows for irrigated agriculture. Much of the irrigation water is consumed by plants, resulting in a concentration of dissolved salts. The unused water, called irrigation return-flow, dissolves salts from the soil and underlying geologic materials as it moves to the river. The concentration of water through evaporation and dissolution of chemical constituents result in a large increase in specific conductance between Trinidad and near Hoehne. Similar increases occur on other larger streams in Area 61. 


\section{EXPLANATION}

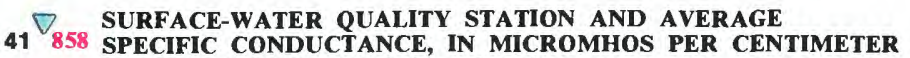
tigure 4.1-1 BOUNDARY BETWEN CRETACEOUS ROCKS TO EAST
AND OTHER FORMATIONS-ALSO APPROXIIATE BOUNDAR
BETWEN MOUNTAINS OR MESA AND PLAINS
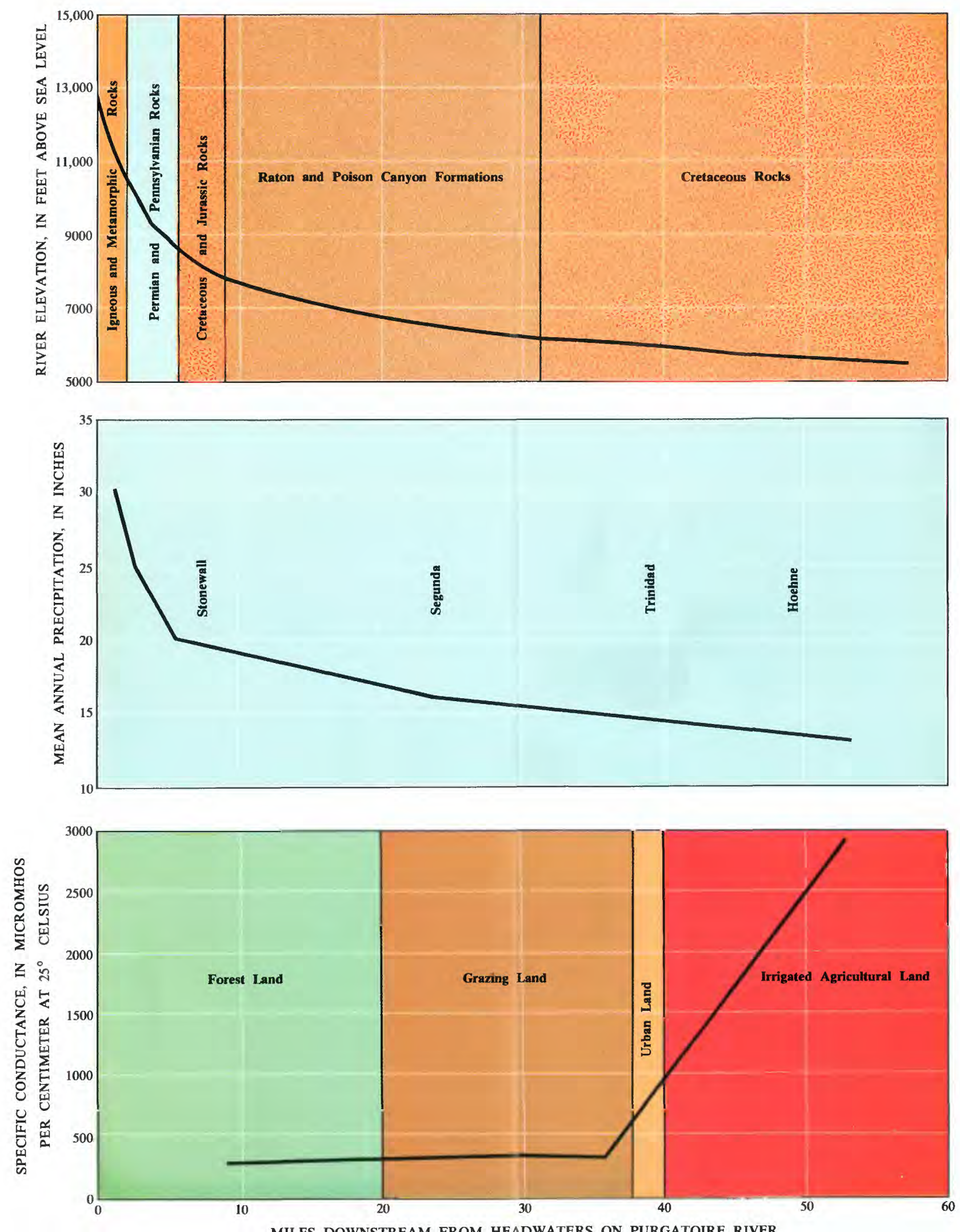

Figure 6.1.1-2 Relationships between elevation, geology, precipitation, land use, and specific conductance for the Purgatoire River in Colorado. 


\title{
6.0 SURFACE-WATER QUALITY--Continued \\ 6.1 Specific Conductance--.Continued \\ 6.1.2 Relationship to Stream Discharge
}

\section{Specific Conductance of Streamflow Is Inversely Related to Discharge}

\author{
Relationships between specific conductance and streamflow are \\ affected by geology.
}

Relationships between specific conductance and streamflow have been developed for the 10 stations shown in figure 6.1.2-1. The linear relationships between the logarithms of discharge and specific conductance were developed using the method of least squares at stations where visual inspection of the plotted data indicated a linear trend. The relationships (fig. 6.1.2-2) are inverse; when discharge increases, specific conductance decreases. The position and slope of the lines in figure 6.1.2-2 are significantly affected by local bedrock geology.

The specific conductance of streamflow is largely determined by the specific conductances of its two major components--direct runoff and base flow. Direct runoff to streams occurs as a result of snowmelt or rainfall runoff. Direct runoff usually has a low specific conductance because the relatively pure water from snowmelt or rainfall has minimal opportunity to dissolve salts enroute to the stream. The highest discharges of streams in Area 61 generally occur as a result of direct runoff, causing the curves in figure 6.1.2-2 to slope down at high discharges. When direct runoff is not occurring, streamflow may be maintained at base flow by ground-water inflows. Because ground water is in contact with geologic materials for a much longer period than direct run- off, ground water generally has a higher specific conductance because of dissolution of rocks and minerals. The result is a greater specific conductance of streamflow during base flow.

The specific conductance of base flow depends on the geologic formation or formations from which base flow is contributed (fig. 6.1.2-2) at each site. The highest specific conductances in base flow occur at sites where the base flow originates in Cretaceous rocks and the lowest at sites where base flow originates from igneous, metamorphic, Pennsylvanian, or Permian rocks. Intermediate specific conductance occurs at sites where base flow is contributed from the Raton and Poison Canyon Formations. These trends in the specific conductance of base flow are similar to what is observed in ground-water samples from wells completed in these formations.

The inverse relationship of specific conductance to discharge and associated seasonal variations is further exemplified at the streamflow-gaging station on the Purgatoire River at Madrid, Colo. (fig. 6.1.2-3). Similar seasonal variations can be expected at other sites shown in figure 6.1.2-1. 


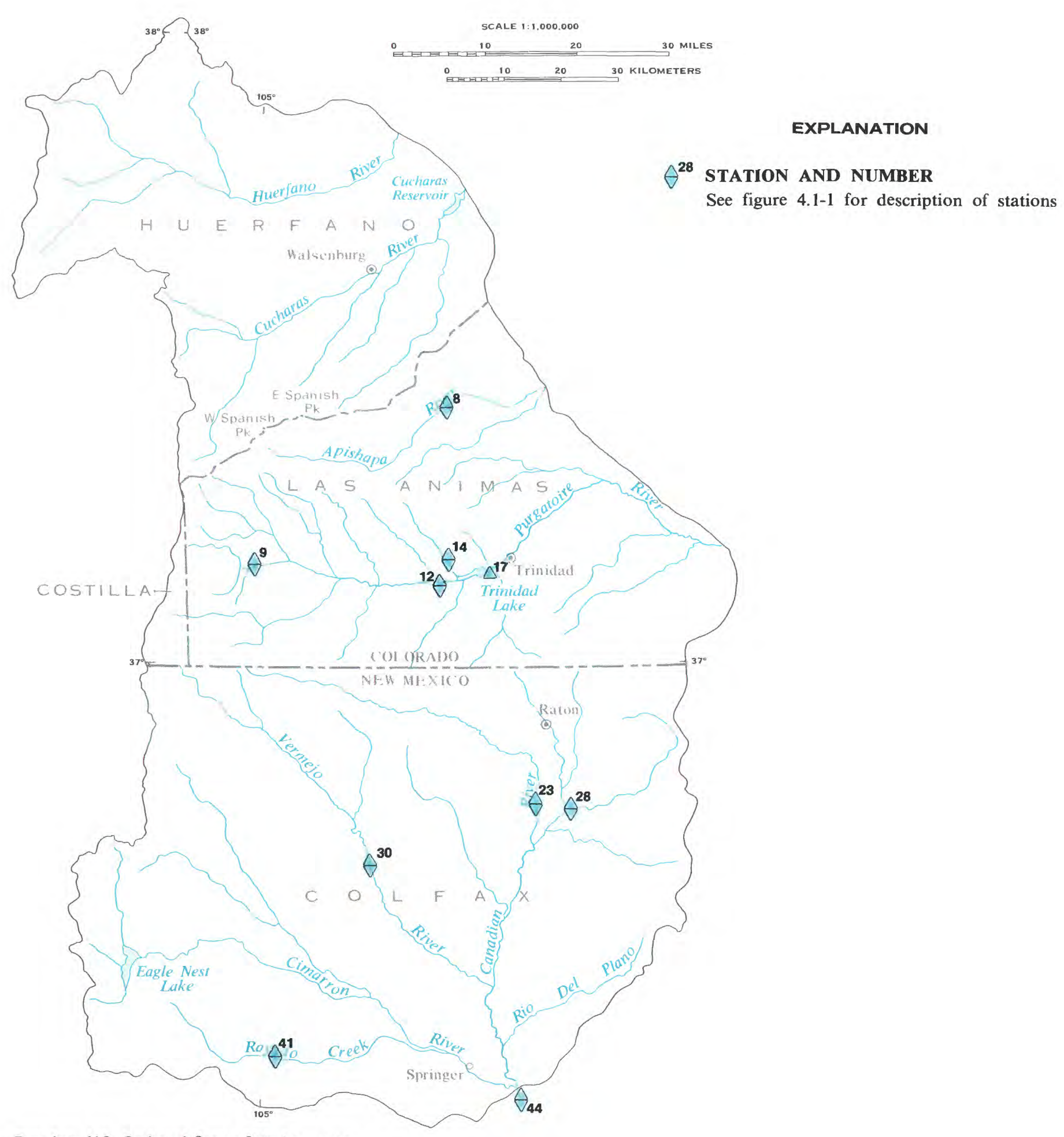

Base from U.S. Geelogical Survey State base maps
1.500,000; Colorado, 198, and New Mexico, 1967 ?

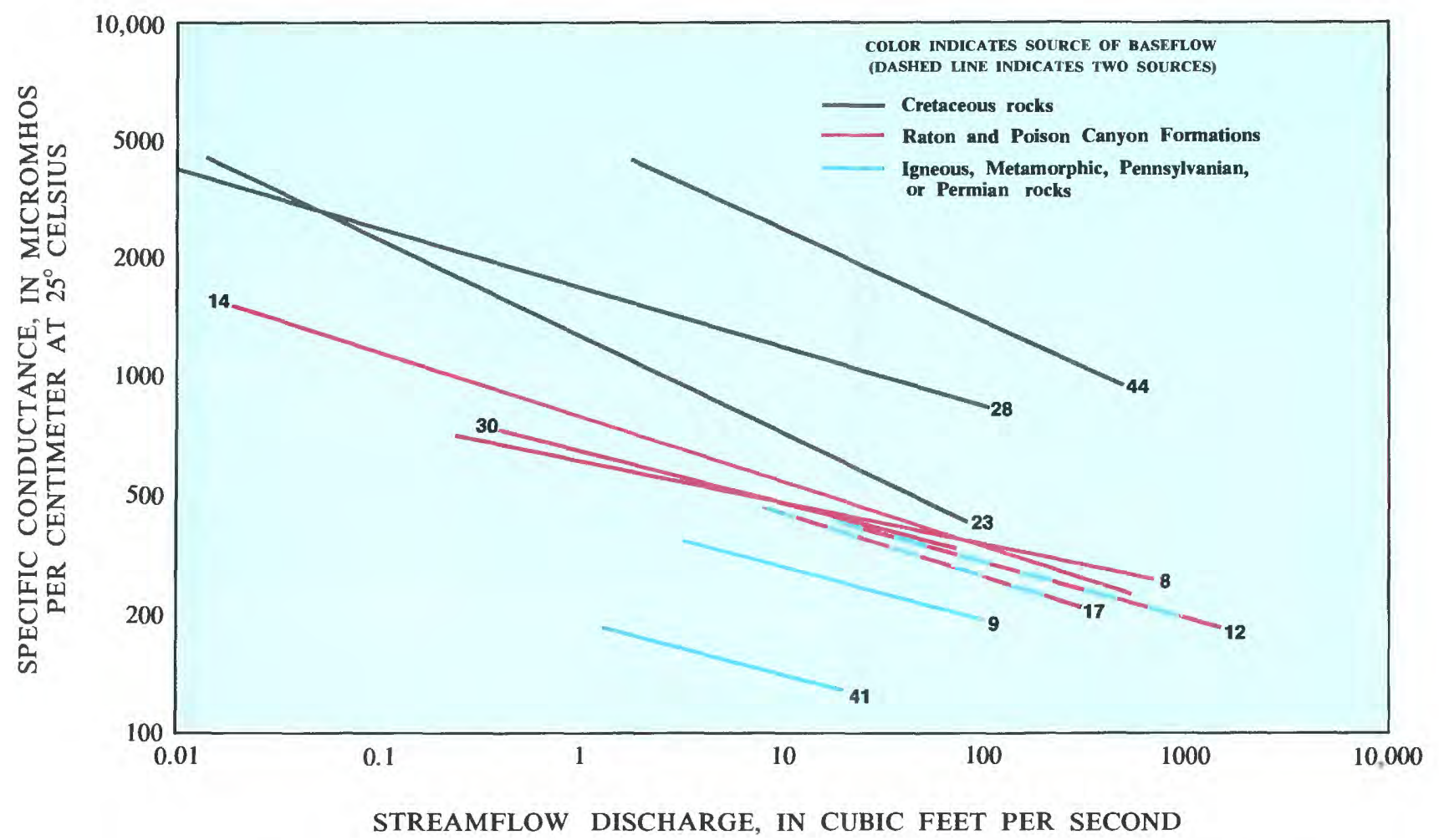

Figure 6.1.2-2 Variation in specific conductance and streamflow discharge at 10 stations.

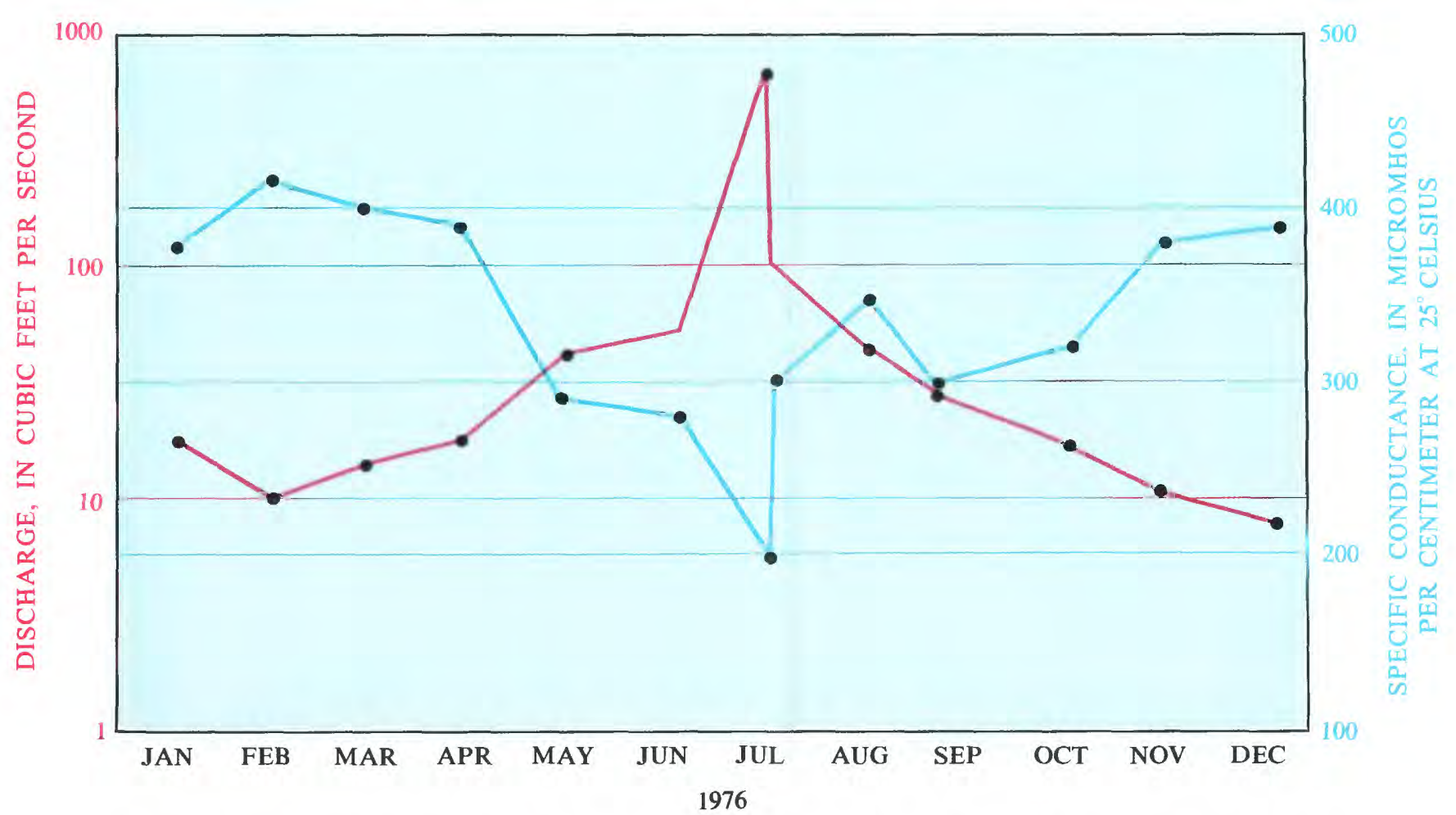

Figure 6.1.2-3 Seasonal variation of streamflow discharge and specific conductance at station 12, Purgatoire River, at Madrid, Colorado. 


\author{
6.0 SURFACE-WATER QUALITY--Continued \\ 6.1 Specific Conductance--Continued \\ 6.1.3 Relationship to Major Dissolved Constituents
}

\title{
Concentrations of Major Dissolved Constituents Are Directly Related to Specific Conductance
}

\author{
Specific conductance can be used to estimate concentrations \\ of major dissolved constituents.
}

Direct relationships between specific conductance and the concentrations of major dissolved constituents have been developed for water at six streamflow-gaging stations in Area 61 (fig. 6.1.3-1). The relationships can be used to estimate the concentration of major dissolved constituents if specific conductance is known. The relationships for the Purgatoire River at Madrid, Colo. (station 12 in fig. 6.1.3-1) are illustrated in figure 6.1.3-2; similar relationships exist for the other five stations. The relationships for all six stations are given mathematically in table 6.1.3-1.

To estimate the expected concentration of any constituent shown in table 6.1.3-1, multiply the specific conductance, measured in micromhos per centimeter at $25^{\circ}$ Celsius, by the value in the "Slope" column for that constituent and add the value in the "Intercept" column. The result is the estimated concentration of the constituent, in milligrams per liter. For example, suppose a specific conductance of 340 micromhos per centimeter at $25^{\circ}$ Celsius was measured at the Purgatoire River at Madrid, Colo., and an estimate of sulfate concentration was desired. To make this estimate, multiply 340 by 0.157 (the value in the "Slope" column of table 6.1.3-1 for sulfate at the station) and add -13.6 (the value in the "Intercept" column). The estimated sulfate concentration is $40 \mathrm{mg} / \mathrm{L}$ (milligrams per liter). The difference between the estimated and the actual sulfate values is a function of the standard error shown in table 6.1.3-1--the larger the standard error, the great- er the possible difference between the estimated and the actual value. Conversely, if the standard error of estimate is small, the actual sulfate concentration is likely to be quite similar to the estimated value. Similar calculations based on the measured specific conductance of 340 micromhos per centimeter at $25^{\circ}$ Celsius would result in the following estimated concentrations of other water-quality constituents: Sodium, $14 \mathrm{mg} / \mathrm{L}$; calcium, $43 \mathrm{mg} / \mathrm{L}$; magnesium, 10 $\mathrm{mg} / \mathrm{L}$; bicarbonate, $158 \mathrm{mg} / \mathrm{L}$; chloride, $2 \mathrm{mg} / \mathrm{L}$; and dissolved solids, $197 \mathrm{mg} / \mathrm{L}$. Similar calculations also can be made for other specific conductances at the same station or for other stations.

A way to compare the relative abundance of major ions at different stations is by using the pie charts in figure 6.1.3-1. These charts show the average relative abundance of major ions at each station. Some variations in relative abundance of major ions occur that primarily are related to geology. In the headwaters, where bedrock primarily is igneous and metamorphic rocks and rocks of Pennsylvanian and Permian age (stations 9 and 35), calcium and bicarbonate are the dominant ions present. As streams flow eastward across the clastic deposits of the Raton and Poison Canyon Formations, the relative concentrations of sodium and, to a lesser extent, sulfate increase (stations 8,12 , and 30). As streams flow onto the plains formed from Cretaceous rocks, sodium and sulfate concentrations increase and become the dominant cation and anion (station 23). 

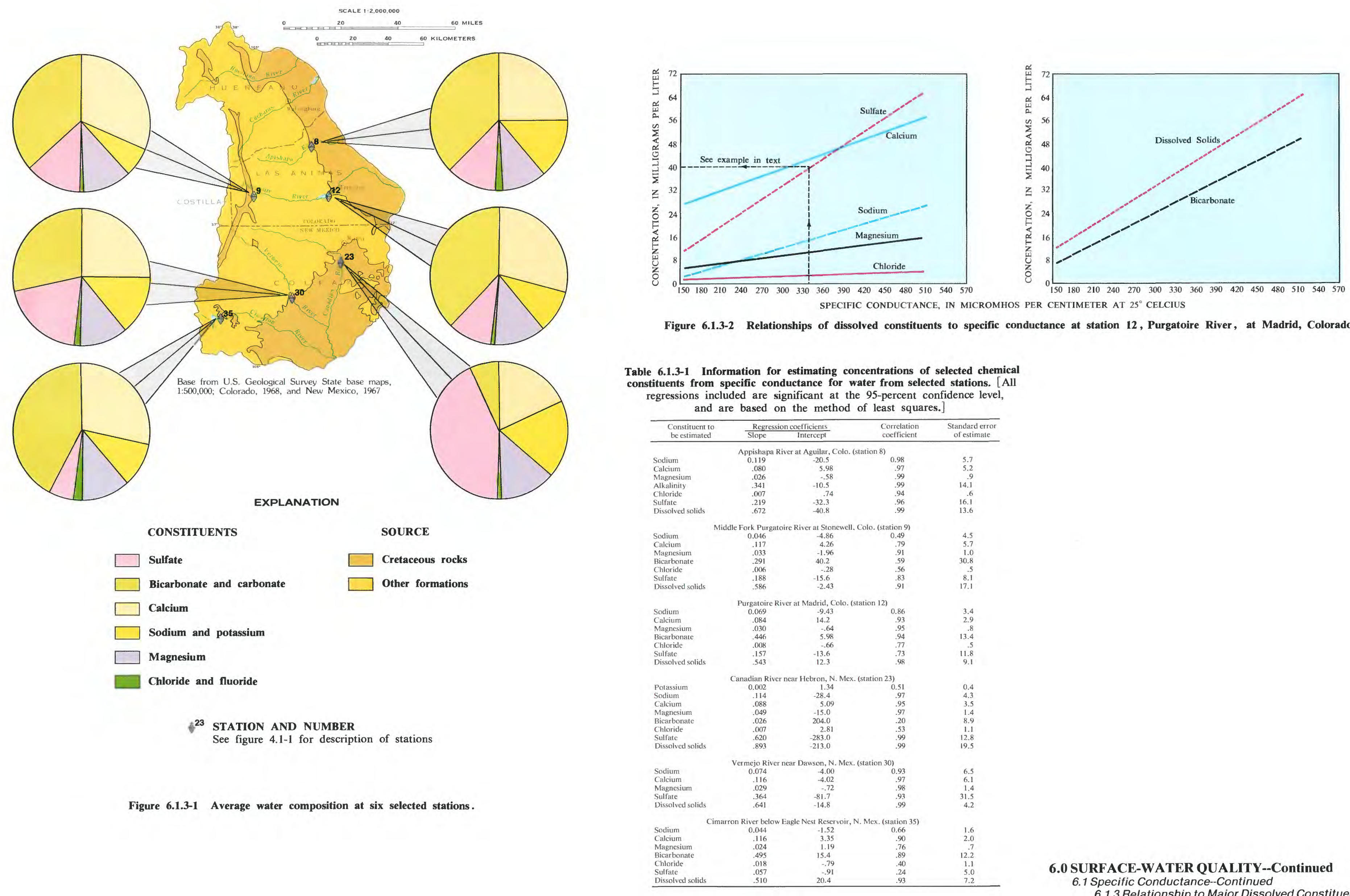

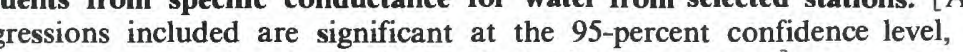

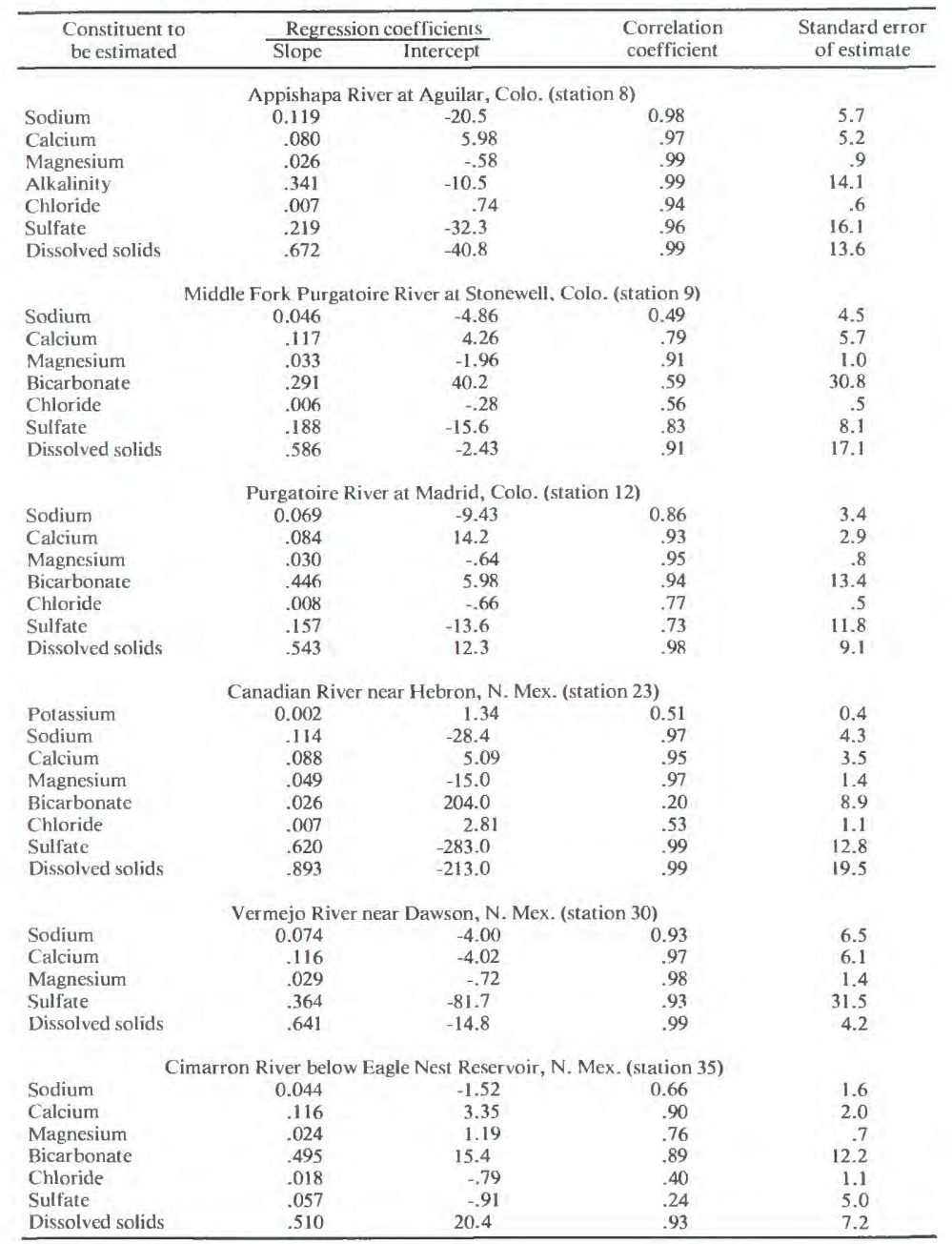




\title{
6.0 SURFACE-WATER QUALITY--Continued \\ $6.2 \mathrm{pH}$
}

\section{The pH of Streamflow Generally Is Almost Neutral to Slightly Alkaline}

\author{
The $\mathrm{pH}$ of streamflow fluctuates from 6.7 to 9.3.
}

The $\mathrm{pH}$ of water is a measure of its acidity. If the $\mathrm{pH}$ is 7.0 , the water is neutral. Water with a $\mathrm{pH}$ less than 7.0 is acidic, and water with $\mathrm{pH}$ greater than 7.0 is alkaline. According to Hem (1970, p. 93), the $\mathrm{pH}$ of streamflow generally is between 6.5 and 8.5 unless it has been affected by pollution. The $\mathrm{pH}$ of streamflow at sites in Area 61 is usually within this range of values (fig. 6.2-1), although values greater than 8.5 have been measured at some locations.

Because pollution sources that might cause excessively alkaline water are not known to exist in Area
61 , it is presumed that $\mathrm{pH}$ values greater than 8.5 are caused by natural processes. For example, excessively alkaline water can result from use of dissolved carbon dioxide by aquatic plants during periods of active photosynthesis. These periods occur during daylight hours when most measurements of $\mathrm{pH}$ in Area 61 were made. Although data are somewhat limited, the $\mathrm{pH}$ of water from sources related to coal mining in Area 61 (table 6.2-1) is neutral to alkaline, but is within the range of $\mathrm{pH}$ values measured at streamflow stations (fig. 6.2-1). 


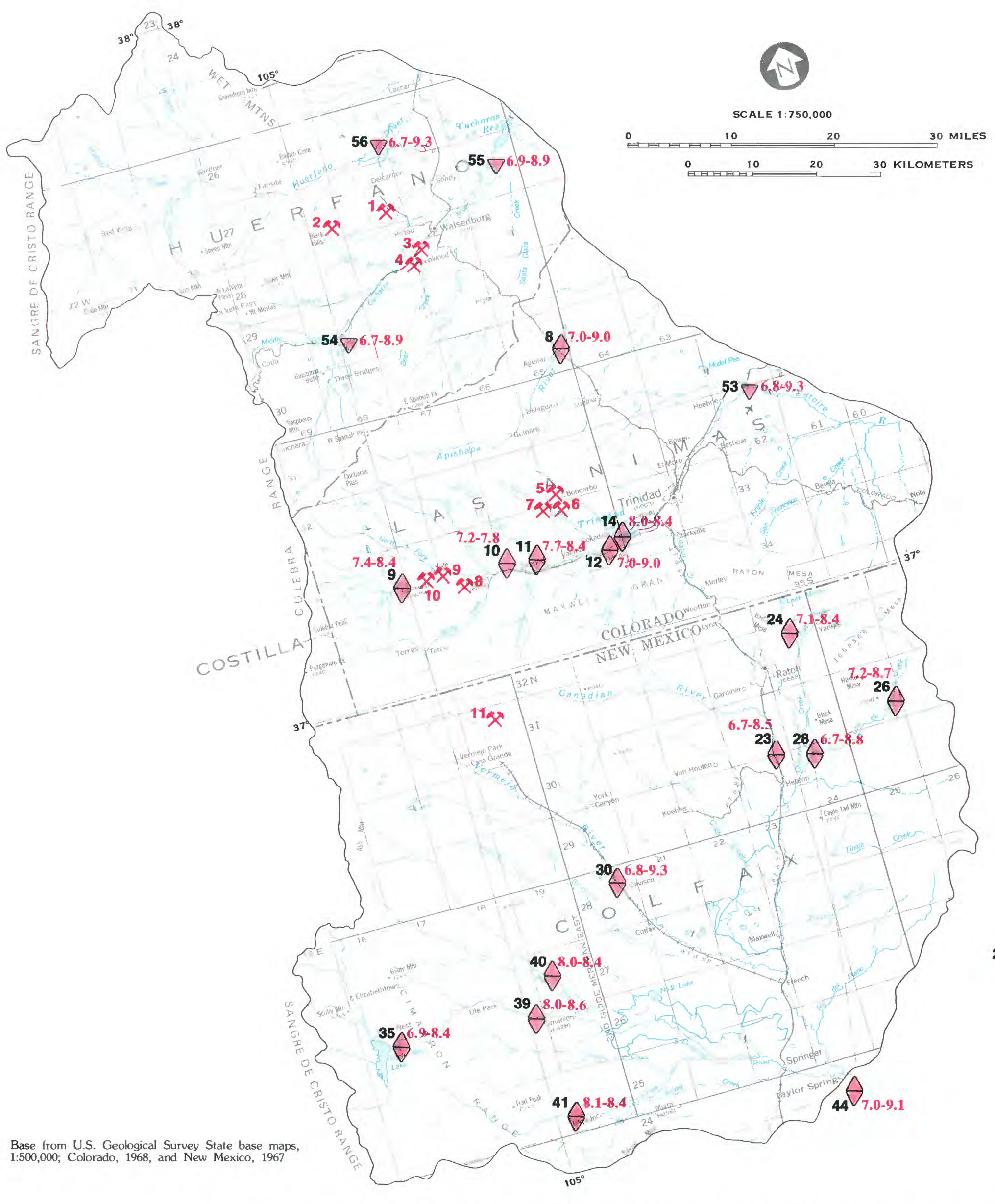

Table 6.2-1 $\mathrm{pH}$ of water from coal-mining-related sources.

\begin{tabular}{|c|c|c|c|}
\hline $\begin{array}{l}\text { Map } \\
\text { No. }\end{array}$ & Description of source $^{1}$ & $\begin{array}{c}\text { Number } \\
\text { of } \\
\text { samples }\end{array}$ & $\mathrm{pH}^{2}$ \\
\hline & Water from Gordon Mine (abandoned) & 1 & 7.7 \\
\hline 2 & Water from Butte Valley Mine (abandoned) & 1 & 7.3 \\
\hline 3 & Water from Mutual Mine (abandoned) & 1 & 7.9 \\
\hline & Water from Diggerhead Mine (abandoned) & 1 & 8.2 \\
\hline 5 & Seep from Boncarbo Mine & & \\
\hline & tailings pile (abandoned) & 1 & 7.0 \\
\hline $\begin{array}{l}6 \\
7\end{array}$ & $\begin{array}{l}\text { Water from Boncarbo Mine (abandoned) } \\
\text { Seep from Jacks Mine }\end{array}$ & & \\
\hline & tailings pile (abandoned) & 1 & 9.2 \\
\hline & Discharge waler trom lraxweri Minte (active) & & \\
\hline 9 & Seep from Allen Mine tailings pile (active) & 1 & 8.0 \\
\hline & $\begin{array}{l}\text { Discharge water from Allen Mine (active) } \\
\text { D. }\end{array}$ & 12 & 8.3 \\
\hline \multirow[t]{2}{*}{$\begin{array}{l}10 \\
11\end{array}$} & Discharge water from York Canyon & & \\
\hline & Mine (active) & 11 & 8.3 \\
\hline
\end{tabular}

'For abandoned mines, $\mathrm{pH}$ was measured in water standing in mine or pumped from mine.

${ }^{2}$ Median value if more than one sample available.

\section{EXPLANATION}

${ }^{26} 7.2-8.7$ SURFACE-WATER QUALITY SITE

See figure $4.1-1$ for description of station

7 COAL MINING SITE AND NUMBER

$\mathrm{pH}$ data summarized in Table $6.2-1$ 


\title{
Sediment Concentrations Increase Substantially During Short Periods of High Streamflow
}

\author{
Large sediment concentrations occur during periods of high streamflow caused by \\ intense thunderstorms. Sodiment-laden peak flows resulting from these storms \\ usually occur suddenly with rapid increases in water-surface elevation \\ (or stage).
}

Sediment concentrations of 50,000 to 200,000 milligrams per liter during peak flows are common in areas underlain by the Raton or Poison Canyon Formation, which consist primarily of sandstone and shale. A sediment-laden peak flow is shown below (fig. 6.3.1-1) at the Sarcillo Canyon streamflowgaging station (station 11 in fig. 6.3.1-2), a tributary of the Purgatoire River. The water discharge when the photograph was taken was approximately 11,000 cubic feet per second, and the sediment concentration was about 100,000 milligrams per liter. After the flood peak passed, the stage declined 7 feet in 2 hours. Base flow at this station is 0.06 to 0.20 cubic foot per second, and the volume of sediment carried during base flow is minimal. A typical relationship of sediment concentration to streamflow and to river stage in the area is illustrated in figure 6.3.1-3 for a peak flow at the Carpios Canyon streamflow-gaging station (station 16 in fig. 6.3.1-2), a smaller tributary to the Purgatoire River. Sediment concentration increased rapidly with streamflow to a maximum just before or coincident with the peak stream discharge.

Sediment concentrations during peak flows are much less near headwater regions where streams drain mostly Pennsylvanian and Permian limestone, sandstone, and shale as well as Precambrian igneous and metamorphic rocks. The maximum sediment concentration determined during peak flow in the Middle Fork of the Purgatoire River at streamflowgaging station 9 (fig. 6.3.1-2) was 4,000 milligrams per liter. 


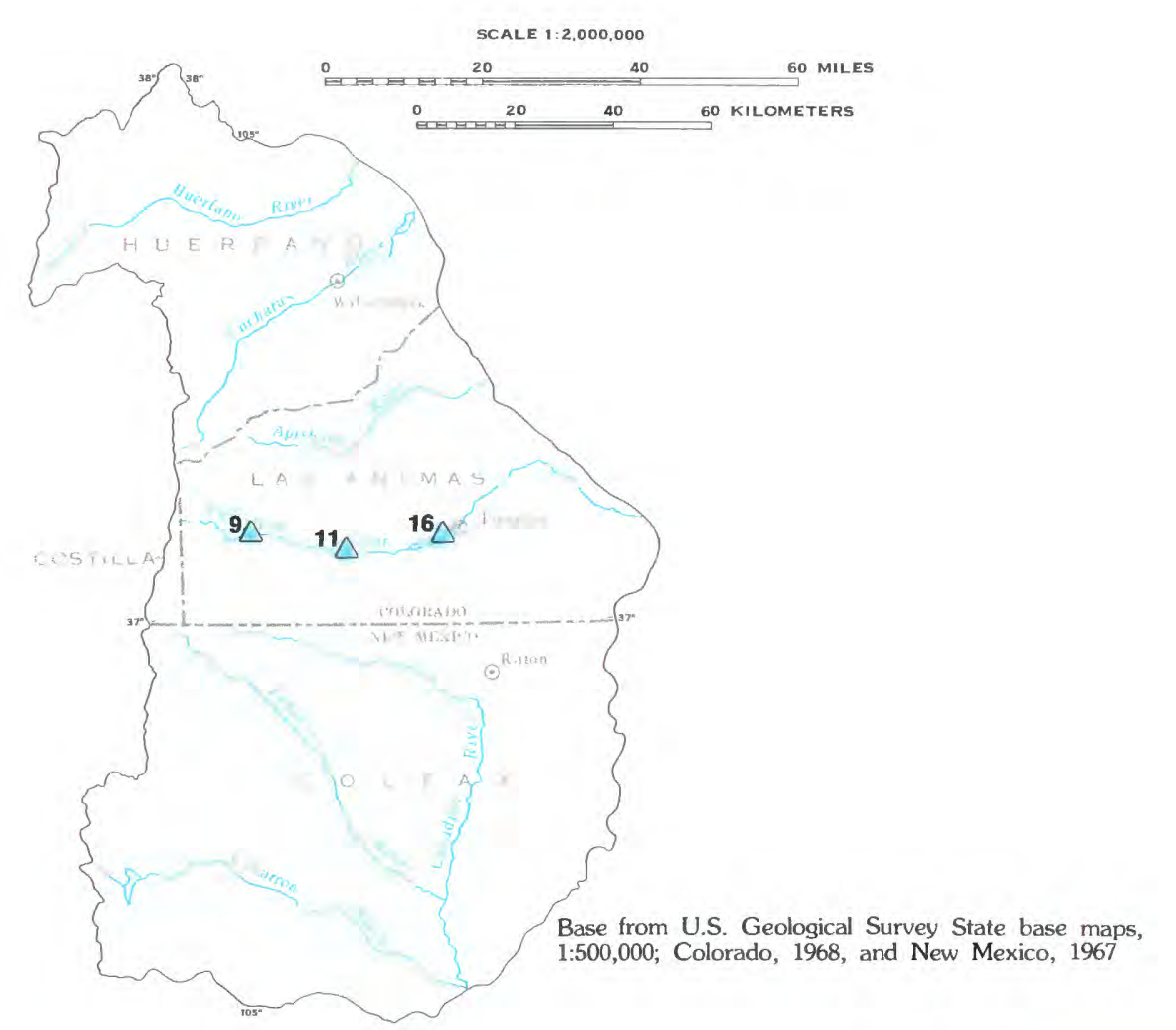

Figure 6.3.1-2 Location of selected strenthow-gaging stations.
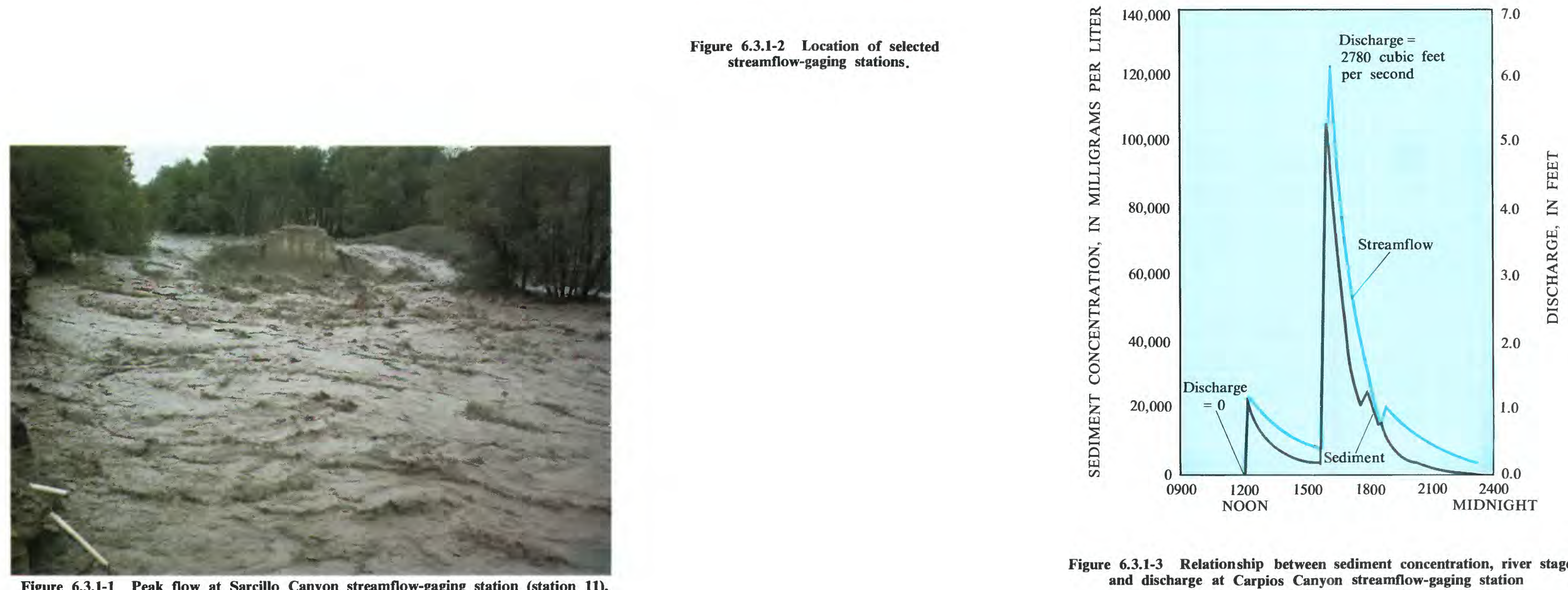

on August 10, 1981, showing sediment-laden turbulent flow.
ond

Figure 6.3.1-3 Relationship between sediment concentration, river stage, and discharge at Carpios Canyon streamflow-gaging station
(station 16), July 26, 1981. 


\author{
6.0 SURFACE-WATER QUALITY--Continued \\ 6.3 Sediment--Continued \\ 6.3.2 Sediment Yields
}

\title{
Sediment Yields Are as Much as 2,840 Tons Per Square Mile Per Year
}

\author{
Computed annual suspended-sediment yields at four stations in the study area \\ ranged from 300 to 2,840 tons per square mile per year.
}

The streamflow at eight streamflow-gaging stations in Area 61 was sampled for suspended sediment. However, sufficient data for analysis are available only for stations 8 (Apishapa River at Aguilar, Colo.), 10 (Molina Canyon near Weston, Colo.), 14 (Reilly Canyon at Cokedale, Colo.), and 16 (Carpios Canyon near Jansen, Colo.) (fig. 6.3.2-1). The geology of the areas upstream from these four stations is similar (fig. 6.3.2-1); therefore, differences in sediment yield and sediment discharge cannot be attributed to variations in geology.

Area 61 is characterized by a large range of sediment yields and instantaneous suspended-sediment discharges. The sediment yield in the area ranged from 300 to 2,840 tons per square mile per year, and measured instantaneous suspended-sediment discharge ranged from 0.003 to 612,300 tons per day. These large yields and discharges probably are due to a combination of basin characteristics, such as the semiarid climate and erodible soils.
Relations between water and suspended-sediment discharge such as those shown in figure 6.3.2-2 can be used to estimate sediment loads for water discharges of magnitudes within the range of the relations. These relations were developed from data collected at the four streamflow-gaging stations during both high and low flows. By using the daily streamflow record at each of these stations and the relations in figure 6.3.2-2, the annual sediment yield can be estimated for each of the respective drainage basins. The yields given in figure 6.3.2-2 are averages determined from 4 years of record that were available and show that sediment yield decreases as drainage area increases. This relation is a result of the increased annual production of sediment with decreasing drainage area and the more efficient transport of this sediment to the stream channel by overland flow in the smaller drainage basins. This conclusion also has been reached in studies of other semiarid areas of the West (Brune, 1950. Hadley and Schumm, 1961). 

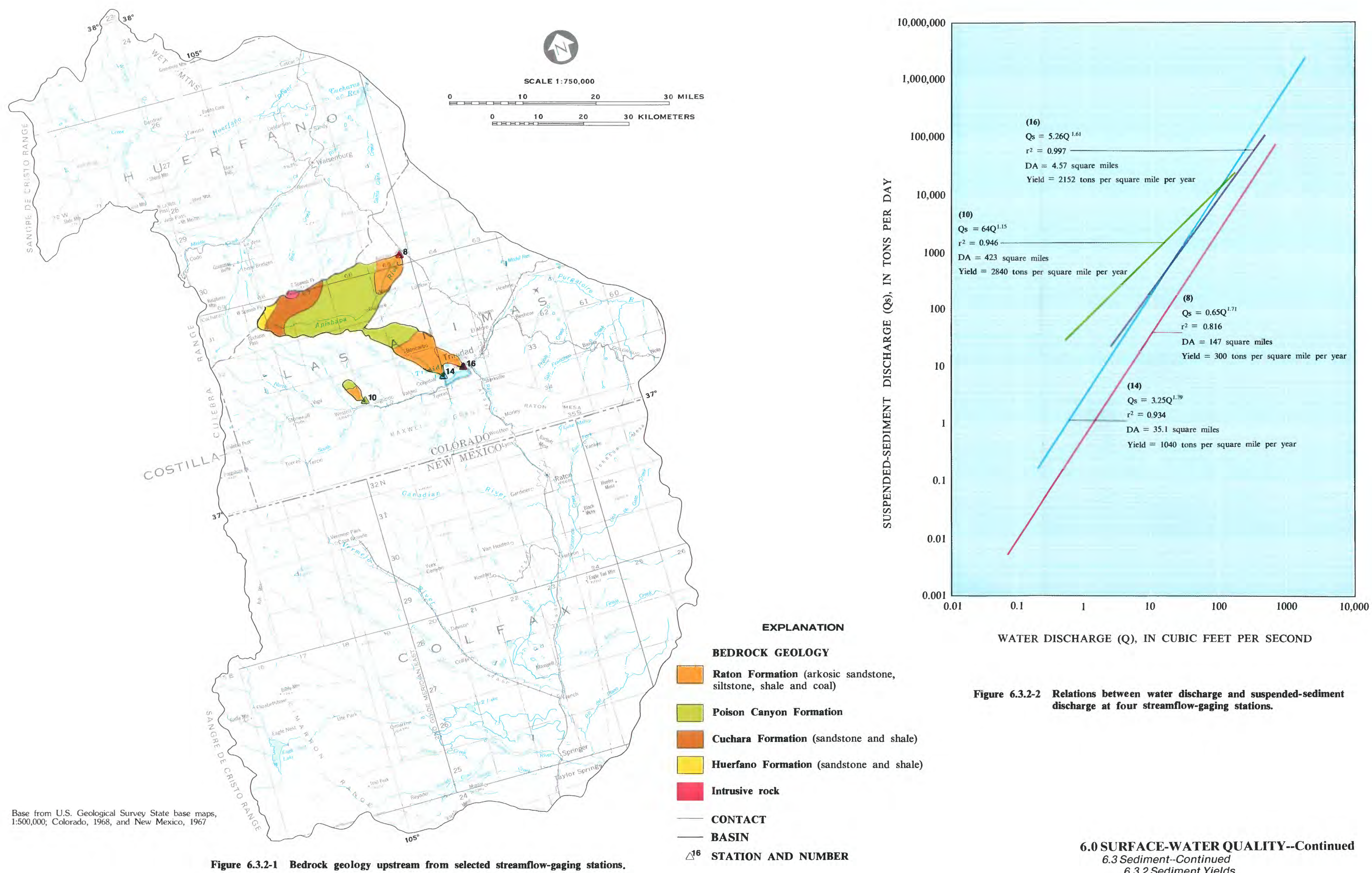

WATER DISCHARGE (Q), IN CUBIC FEET PER SECOND

Figure 6.3.2-2 Relations between water discharge and suspended-sediment discharge at four streamflow-gaging stations. 


\title{
Large Concentrations of Total Recoverable Metals Are Associated with Large Concentrations of Suspended Sediment
}

\author{
Iron and aluminum are the dominant metals found with suspended sediment.
}

Concentrations of total recoverable metals increase with concentrations of suspended sediment during high streamflow. Of those metals analyzed, total recoverable iron and aluminum were dominant. Total recoverable manganese, zinc, copper, and lead occurred in intermediate concentrations; total recoverable nickel, chromium, cobalt, molybdenum, mercury, and cadmium were present in smaller concentrations. The data indicate the metals primarily are associated with the suspended sediment rather than in the dissolved form. Data for concentrations of sediment and total recoverable metals are available at the eight streamflow-gaging stations shown in figure 6.4-1. The drainage basins of all stations except station 9 are underlain by the Raton and Poison Canyon Formations. The drainage basin of station 9 is underlain by igneous and metamorphic rocks and rocks of Permian and Pennsylvanian age located in the Culebra Range.

Maximum total recoverable iron concentrations ranged from $43,000 \mu \mathrm{g} / \mathrm{L}$ (micrograms per liter) at station 9 to $930,000 \mu \mathrm{g} / \mathrm{L}$ at station 16. Maximum total recoverable aluminum concentrations ranged from $100,000 \mu \mathrm{g} / \mathrm{L}$ at station 9 to $800,000 \mu \mathrm{g} / \mathrm{L}$ at station 16. Concentrations of total recoverable iron and aluminum during low-flow periods were less than $150 \mu \mathrm{g} / \mathrm{L}$ at all stations.

Analysis of data collected for sediment and total recoverable metals at the eight streamflow-gaging stations in figure 6.4-1 indicates that a general relationship exists between some metals and sediment concentrations. The relationships, which are illustrated for station 12 (Purgatoire River at Madrid, Colo.) in figure 6.4-2, can be used to estimate the concentration of selected total recoverable metals from sediment concentration at this station. For example, assume a water sample at station 12 had a suspended-sediment concentration of 50,000 milligrams per liter. The estimated total recoverable iron concentration is approximately $540,000 \mu \mathrm{g} / \mathrm{L}$. A statistical summary of selected metals analyzed is shown in table 6.4-1. The maximum values occurred during storm runoff. 


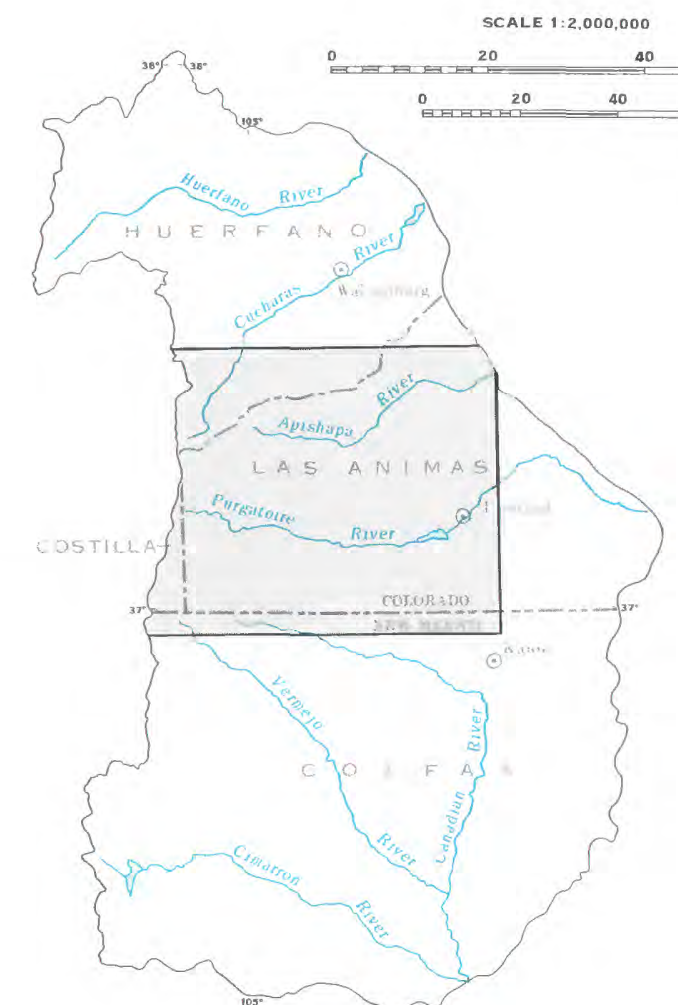

Base from U.S. Geological Survey Statat base maps,
1.500,000; Colorado, 1988, and New Mexico, 1967 ,

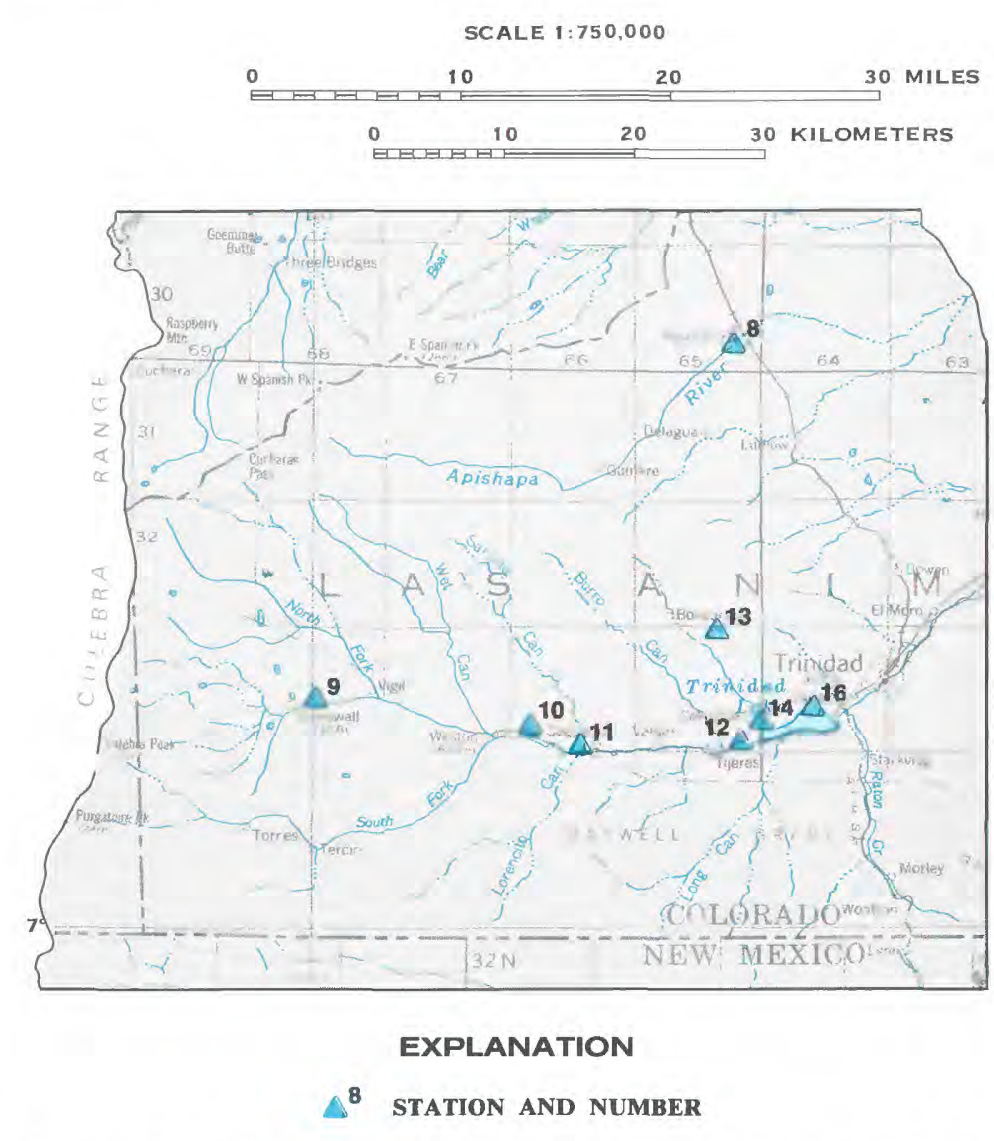

Figure 6.4-1 Stations where data are available for concentrations of total recoverable metals and suspended sediment.
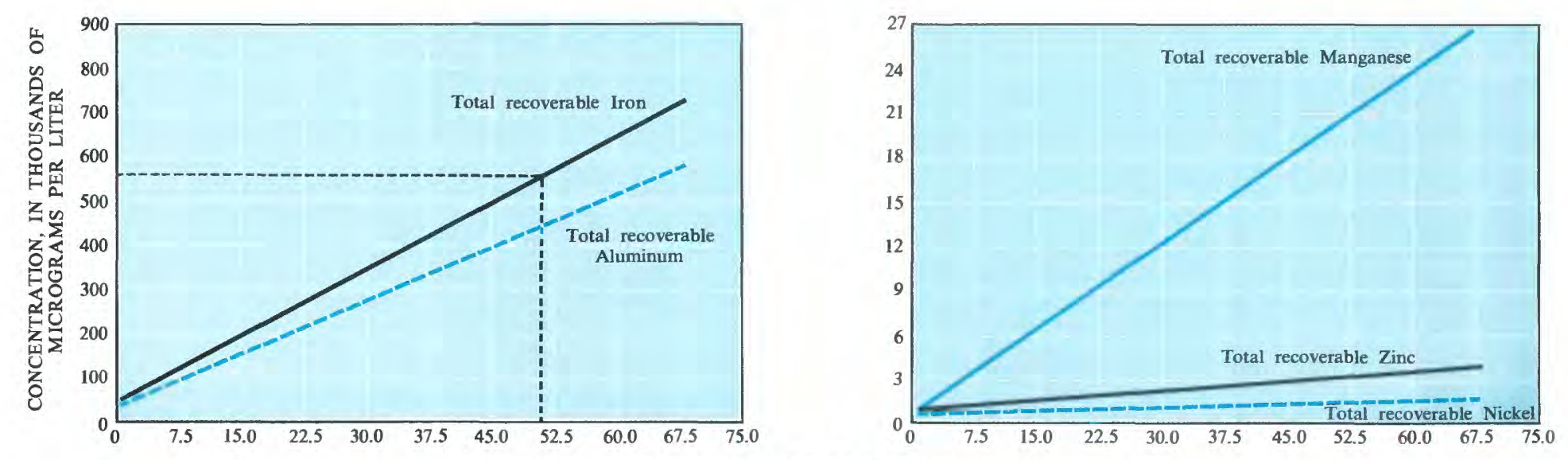

SUSPENDED SEDIMENT, IN THOUSANDS OF MILLIGRAMS PER LITER
Table 6.4-1--Statistical summary of total recoverable metals analyzed.

\begin{tabular}{|c|c|c|c|c|c|c|c|c|c|c|c|}
\hline 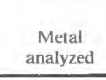 & $\begin{array}{l}\text { Number } \\
\text { samples }\end{array}$ & 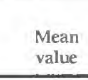 & 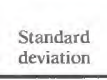 & 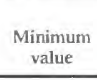 & $\begin{array}{c}\substack{\text { Maximum } \\
\text { value }} \\
\text { val }\end{array}$ & $\begin{array}{l}\text { Metal } \\
\text { analyzed } \\
\text { nats }\end{array}$ & $\begin{array}{c}\text { Number } \\
\text { samples } \\
\text { sampes }\end{array}$ & $\begin{array}{l}\text { Mean } \\
\text { value } \\
\text { and }\end{array}$ & 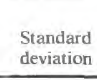 & 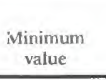 & 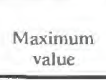 \\
\hline \multicolumn{6}{|c|}{ Apishapa River a a Aguilar, Colo. (station 8) } & \multicolumn{6}{|c|}{ Purgatorie River a Madrid, Colo. (station 12) } \\
\hline 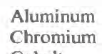 & ${ }_{20}^{24}$ & $\begin{array}{c}145.300 \\
186\end{array}$ & 145,100 & 100 & 370,000 & 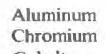 & $\begin{array}{c}100 \\
5\end{array}$ & $\begin{array}{l}188,600 \\
276\end{array}$ & 192,000 & 望0 & 500,000 \\
\hline \multirow{4}{*}{ 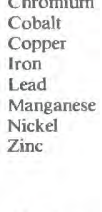 } & $\begin{array}{l}20 \\
24 \\
27\end{array}$ & $\begin{aligned} 1775 \\
24500\end{aligned}$ & 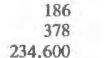 & 1 & 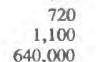 & 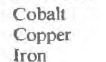 & 11 & $\begin{array}{c}159 \\
214 \\
13500\end{array}$ & 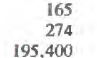 & ${ }_{20}^{5}$ & 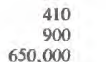 \\
\hline & $\begin{array}{l}21 \\
25 \\
27\end{array}$ & $\begin{array}{l}169 \\
8,760 \\
8.09\end{array}$ & $\begin{array}{l}24,094 \\
9190\end{array}$ & 10 & 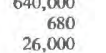 & 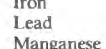 & $\begin{array}{l}13 \\
12 \\
15\end{array}$ & $\begin{array}{l}215 \\
4.340 \\
403\end{array}$ & $\begin{array}{l}335 \\
7500\end{array}$ & ${ }_{10}^{2}$ & $\begin{array}{l}6,1,000 \\
28000 \\
2800\end{array}$ \\
\hline & 24 24 & $\begin{array}{l}2,334 \\
1,30\end{array}$ & $\begin{array}{llll}2,250 \\
1,880\end{array}$ & $\frac{2}{10}$ & $\begin{array}{l}840 \\
6,500\end{array}$ & 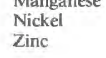 & ii & 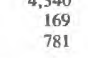 & $\begin{array}{l}2.242 \\
1,080 \\
\text { and }\end{array}$ & $\begin{array}{c}1 \\
10 \\
10\end{array}$ & $\begin{array}{l}2.000 \\
3,300 \\
3,00\end{array}$ \\
\hline & Midalle & ureatoire R & newall, colo. & & & & & 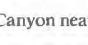 & o. Collo. (stat & & \\
\hline \multirow{2}{*}{$\begin{array}{l}\text { Aluminum } \\
\text { chronium } \\
\text { cobolt } \\
\text { coper }\end{array}$} & ${ }_{3}^{9}$ & 11.400 & $\begin{array}{l}33,200 \\
91.8\end{array}$ & ?o & $\begin{array}{l}100,000 \\
100\end{array}$ & 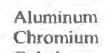 & $\begin{array}{l}10 \\
10\end{array}$ & $68,5009.4$ & 67.600 .1 & $\begin{array}{l}15,000 \\
21\end{array}$ & 250,000 \\
\hline & 7 & $\begin{array}{c}113.3 \\
42.7 \\
340\end{array}$ & $\begin{array}{c}\begin{array}{l}14.4 \\
47.4\end{array} \\
1200\end{array}$ & 20 & 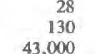 & $\begin{array}{c}\text { cobalt } \\
\text { copper } \\
\text { tron }\end{array}$ & 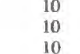 & $\begin{array}{c}39.7 \\
100\end{array}$ & $\begin{array}{c}33.2 \\
35.6\end{array}$ & $\begin{aligned} 4 \\
21 \\
17000\end{aligned}$ & 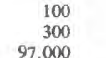 \\
\hline \multirow{2}{*}{ 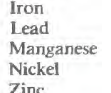 } & i1 & $\begin{array}{l}13.6 \\
54.5 \\
5.5\end{array}$ & $\begin{array}{l}719.9 \\
71.6\end{array}$ & $\frac{0}{10}$ & $\begin{array}{l}47 \\
260\end{array}$ & 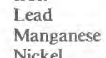 & $\begin{array}{l}10 \\
10\end{array}$ & $\begin{array}{l}51 \\
1,160 \\
1,10\end{array}$ & $\begin{array}{l}28.6 \\
744\end{array}$ & $2_{250}^{2}$ & $\begin{array}{l}100 \\
2,200 \\
200\end{array}$ \\
\hline & 9 & 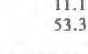 & 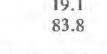 & $\begin{array}{l}1 \\
0\end{array}$ & $\begin{array}{l}240 \\
240\end{array}$ & 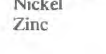 & 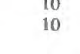 & 然5.5. & 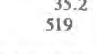 & $110^{9}$ & 1.20 \\
\hline Zine & \multicolumn{4}{|c|}{ Molino Canyon nerr Weston, Colo. (sataion 10) } & & \multicolumn{6}{|c|}{ Reilly Canyon at Cokedale, Colo. (station 14) } \\
\hline \multirow{5}{*}{ 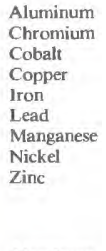 } & ${ }_{26}^{26}$ & $\begin{aligned} 215,000 \\
170\end{aligned}$ & 209,000 & 勇 & $\begin{array}{l}70,0000 \\
7800\end{array}$ & $\begin{array}{l}\text { Suminium } \\
\text { Chromium }\end{array}$ & 27 & $\begin{array}{c}192,200 \\
218\end{array}$ & 155,200 & $\begin{array}{l}70 \\
10\end{array}$ & $\begin{array}{l}500,000 \\
9000\end{array}$ \\
\hline & $\begin{array}{l}26 \\
26 \\
26\end{array}$ & $\begin{array}{l}1.527 \\
318.500 \\
3\end{array}$ & 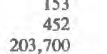 & 染, 830 & $\begin{array}{c}1,600 \\
670,000 \\
670.00\end{array}$ & 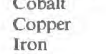 & $\begin{array}{l}21 \\
30 \\
30\end{array}$ & $\begin{array}{l}1350 \\
26100 \\
261000\end{array}$ & $\begin{array}{l}10 \\
1872 \\
10700\end{array}$ & $\begin{array}{c}6 \\
4 \\
10\end{array}$ & $\begin{array}{l}1400 \\
\begin{array}{r}1.900 \\
50.000\end{array}\end{array}$ \\
\hline & ${ }_{26}^{26}$ & $\begin{array}{r}297 \\
11,100\end{array}$ & $\begin{array}{r}301 \\
10,060\end{array}$ & 1,860 & $\begin{array}{c}1,000 \\
38,0,00 \\
3\end{array}$ & $\begin{array}{l}\text { Lead } \\
\text { Manargane }\end{array}$ & $\begin{array}{l}30 \\
30 \\
30\end{array}$ & $\begin{array}{r}311 \\
7,870\end{array}$ & $\begin{array}{l}2.283 \\
7,230 \\
7\end{array}$ & $\begin{array}{l}6 \\
40 \\
40\end{array}$ & $\begin{array}{l}3900 \\
32,000\end{array}$ \\
\hline & 尊6 & 1,530 & $\begin{array}{l}{ }_{1}^{2066} \\
1,660\end{array}$ & $\begin{array}{l}48 \\
3600 \\
360\end{array}$ & $\begin{array}{l}1,000 \\
4,100\end{array}$ & $\begin{array}{l}\text { Niterel } \\
\text { Zinc }\end{array}$ & 年 & $\begin{array}{l}1,230 \\
1,230\end{array}$ & $\begin{array}{l}\frac{186}{972} \\
972\end{array}$ & $\begin{array}{l}3 \\
20\end{array}$ & $\begin{array}{l}\text { 年, } \\
4,000\end{array}$ \\
\hline & & Canyon n & Colo. (tatatio & & & & & Canyon ne & Colo, (tatia & & \\
\hline $\begin{array}{l}\text { Allumium } \\
\text { Crromium }\end{array}$ & $\begin{array}{l}20 \\
17 \\
17\end{array}$ & $\begin{array}{r}235.000 \\
310\end{array}$ & $\begin{array}{l}176,000 \\
315\end{array}$ & $\begin{array}{l}0 \\
0 \\
0\end{array}$ & $\begin{array}{l}600,0000 \\
9000 \\
900\end{array}$ & 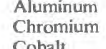 & $\begin{array}{l}19 \\
18 \\
18\end{array}$ & $\begin{array}{l}270,000 \\
205\end{array}$ & $\begin{array}{l}215,400 \\
192\end{array}$ & $\begin{array}{c}70 \\
0 \\
0\end{array}$ & $800,0.000$ \\
\hline $\begin{array}{l}\text { colablt } \\
\text { copoper } \\
\text { Iron }\end{array}$ & $\begin{array}{l}17 \\
20 \\
20\end{array}$ & $\begin{array}{r}263 \\
740 \\
395,000\end{array}$ & $\begin{array}{r}144 \\
436 \\
234,000\end{array}$ & $\begin{array}{c}11 \\
1 \\
190 \\
190\end{array}$ & $\begin{array}{c}1,600 \\
72,000 \\
72,0,00\end{array}$ & 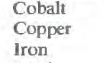 & $\begin{array}{l}18 \\
19 \\
19\end{array}$ & $\begin{aligned} 154 \\
52919 \\
329500\end{aligned}$ & $\begin{array}{r}110 \\
426 \\
23160\end{array}$ & $\begin{array}{l}43 \\
40 \\
20\end{array}$ & 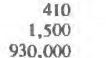 \\
\hline $\begin{array}{l}\text { Letad } \\
\text { Mangang }\end{array}$ & 20 & $\begin{array}{r}38,200 \\
14,200\end{array}$ & $\begin{array}{r}322 \\
10,600 \\
10,60\end{array}$ & $\begin{array}{c}2 \\
10\end{array}$ & 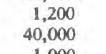 & $\begin{array}{l}\text { Letad } \\
\text { Mangenses }\end{array}$ & $\begin{array}{l}19 \\
19\end{array}$ & $\begin{array}{l}480 \\
9.340\end{array}$ & $\begin{array}{c}3.35 \\
7,150\end{array}$ & $\begin{array}{l}25 \\
{ }_{80}\end{array}$ & $\begin{array}{l}\text { 1.3.300 } \\
2,8,000\end{array}$ \\
\hline $\begin{array}{l}\text { Nickel } \\
\text { Zinc }\end{array}$ & 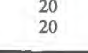 & $\begin{array}{l}3866 \\
1,940 \\
\end{array}$ & $\begin{array}{l}2822 \\
1,170\end{array}$ & $\begin{array}{c}1 \\
10\end{array}$ & $\begin{array}{l}1,000 \\
4,200\end{array}$ & $\begin{array}{l}\text { Nivel } \\
\text { Zincel }\end{array}$ & $\begin{array}{l}19 \\
19\end{array}$ & $\begin{array}{r}2810 \\
1,490\end{array}$ & $\begin{array}{l}212 \\
1,070\end{array}$ & 20 & $\begin{array}{l}740 \\
4,100\end{array}$ \\
\hline
\end{tabular}

Figure 6.4-2 General relationships of total recoverable metals to suspended sediment at station 12

(Purgatoire River at Madrid, Colorado). 


\title{
6.0 SURFACE-WATER QUALITY--Continued \\ 6.5 Biological Quality
}

\section{Aquatic Organisms Are Indicators of Stream Quality}

\author{
Stream quality is reflected by the diversity of aquatic organisms.
}

In general, streams having a diversity index of 3 or 4 are likely to be relatively free of waste materials (Wilhm, 1970, p. R223). Diversity index is a method of relating the number of organisms to the number of species. Where the diversity index is less than 1, the stream or stream reach is likely to be polluted (Wilhm, 1970, p. R223). A conceptual model showing the relationship between stream quality and diversity index is illustrated in figure 6.5-1. As the quality of water in streams deteriorates, fewer species of organisms are able to survive, and the population of the remaining organisms tends to increase because of less competition. Most aquatic organisms are somewhat immobile and, therefore, reflect the conditions in a stream over a long time. Temporal changes in stream velocity, temperature, dissolved oxygen, chemical quality, and sediment concentrations can affect the aquatic community structure.

The taxonomic group which is more abundant than others in a particular community is referred to as the dominant taxon. The dominant taxon generally indicates which species is thriving during some given period and, with limitations, may be used for assessing water quality.

Of those organisms found in Area 61, stoneflies, mayflies, and caddisflies are considered sensitive to instream changes such as increasing concentrations in organic waste and sediment and decreasing dis- solved-oxygen concentrations. Scud, snails, and craneflies are somewhat less sensitive to these changes; midges are considered to be tolerant of such changes.

Biological data have been collected at 45 sites in Area 61 (fig. 6.5-2). Organisms were found to inhabit all streams sampled; however, the Shannon-Wiener diversity index varied greatly ( 0 to 3.25 ). The accuracy of estimating diversity decreases when samples contain fewer than 100 individuals. The data in table 6.5-1 were collected during three different periods and by three different methods. The 1971-72 data were collected by Wentz (1974). The 1974 data were collected by URS/Ken R. White Co. (1975), and the 1980 data were collected by the Colorado Department of Health, Water Quality Control Division (J. D. Gillespie, CF\&I Corp., written commun., 1981). Because the methods varied between sampling periods and the level of taxonomic classification is inconsistent, comparison between data sets was not made. In general, the data indicate the stream quality is such that aquatic organisms of a moderate diversity inhabit the streams in Area 61. Notable exceptions are in the stream reaches downstream from the outflow of wastewater-treatment plants and reaches upstream and downstream from Trinidad Lake, Colo.

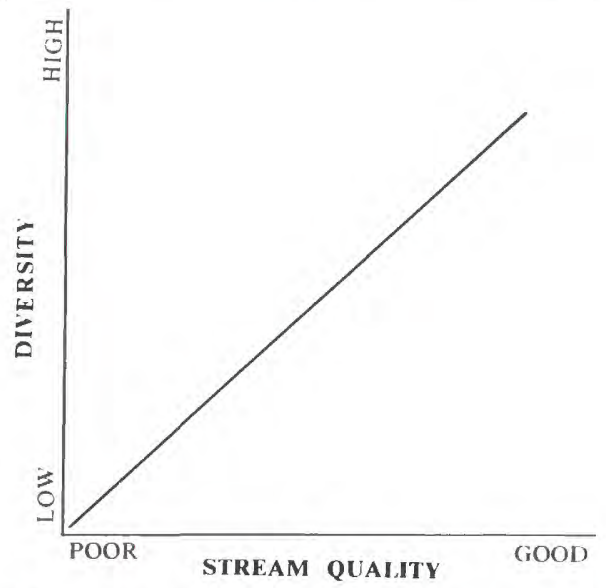

Figure 6.5-1 Diagram of conceptual model showing stream-quality diversity relationship. 


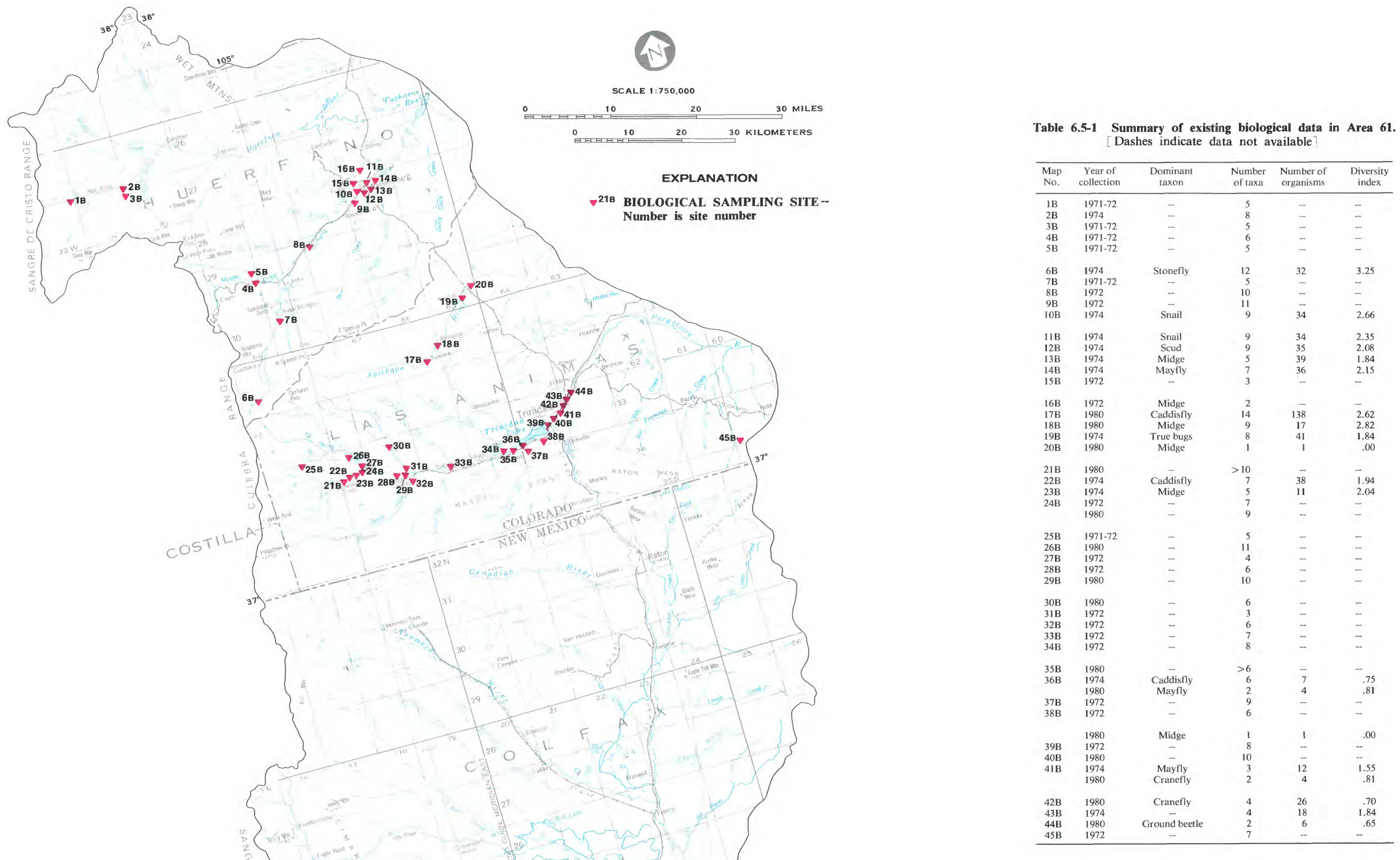




\title{
7.0 GROUND WATER \\ 7.1 Aquifers
}

\section{Unconsolidated Sediments and Bedrock Yield Small to Large Quantities of Ground Water}

\begin{abstract}
Alluvium and talus yield more ground water than bedrock, but are less extensive.
\end{abstract}
Virtually all formations in Area 61 store and transmit water (fig. 7.1-1). Talus and alluvium yield small ( 0.5 to 20 gallons per minute) to large (100 to 500 gallons per minute) quantities of water to wells and springs, but are limited in areal extent; discharges fluctuate seasonally. Bedrock formations generally yield small ( 0.5 to 20 gallons per minute) to moderate ( 20 to 100 gallons per minute) quantities of ground water to wells and springs, and are widespread. In the northwestern and southwestern parts of the area, wells and springs discharging from sandstone and conglomerate may yield large quantities of ground water. Large diameter wells in the Dakota Sandstone (table 7.1-1) also may yield large quantities of ground water. In very dissected terrain, outcropping bedrock aquifers generally are drained by seeps and springs (fig. 7.1-2) and only yield water that is perched above less permeable formations underlying the aquifers.

The principal bedrock aquifers in the area are the Dakota Sandstone-Purgatoire Formation, Fort Hays Limestone Member of the Niobrara Formationupper part of the Carlile Shale, Raton FormationVermejo Formation-Trinidad Sandstone, Cuchara
Formation-Poison Canyon Formation, Devils Hole Formation-Farasita Conglomerate, and volcanic rocks (table 7.1-1). Within these units, sandstone and conglomerate layers and basalt flows transmit most of the water, and shale and coal layers generally retard flow. However, extensively fractured layers and near-surface weathered zones in shale, limestone layers, and a few thick coal seams also transmit water. Formations comprised largely of shale, including the Graneros Shale, lower part of the Carlile Shale, Smoky Hill Marl Member of the Niobrara Formation, Pierre Shale, and Huerfano Formation, retard the downward movement of water and confine flow within the aquifers. Precambrian and Tertiary intrusive and metamorphic rocks, unless extensively fractured, act as barriers to ground-water flow.

The principal sources of ground-water information in Area 61 are Griggs (1948), Powell (1952), McLaughlin and others (1961), McLaughlin (1966), Water, Waste, and Land, Ltd. (1980), Howard (1982), and unpublished U.S. Geological Survey data. 


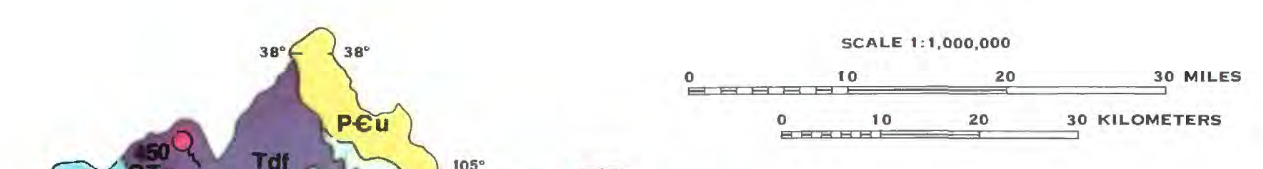

EXPLANATION

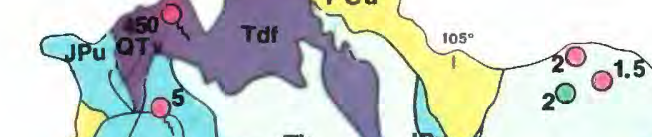

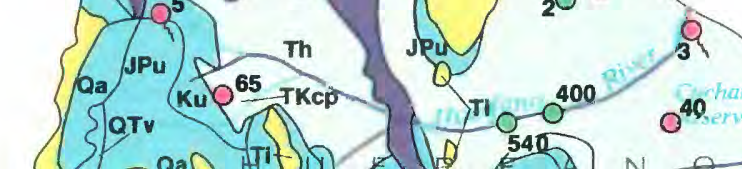
40 Pe

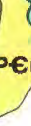

\section{Base from U.S. Geological Survey State base maps.
1:500,000; CColorado, 1968, and New Mexico, 1967}

Figure 7.1-1 Maximum expected yields from small-diameter wells, Raton Basin.

Table 7.1-1 Hydrologic description of formations.

YIELD, IN GALLONS PER MINUTE

Large (100-500)

Moderate (20-100)

Small $(0.5-20)$

Negligible (less than 0.5 )

WELLS AND SPRINGS-Number by symbol is yield, in gallons per minute

${ }^{40}$ W Well discharging from bedrock

Q Spring discharging from bedrock

- Well discharging from alluvium

Q Spring discharging from alluvium CONTACT BETWEEN GEOHYDROLOGIC
UNITS--Unit symbols explained in Table 7.1-1
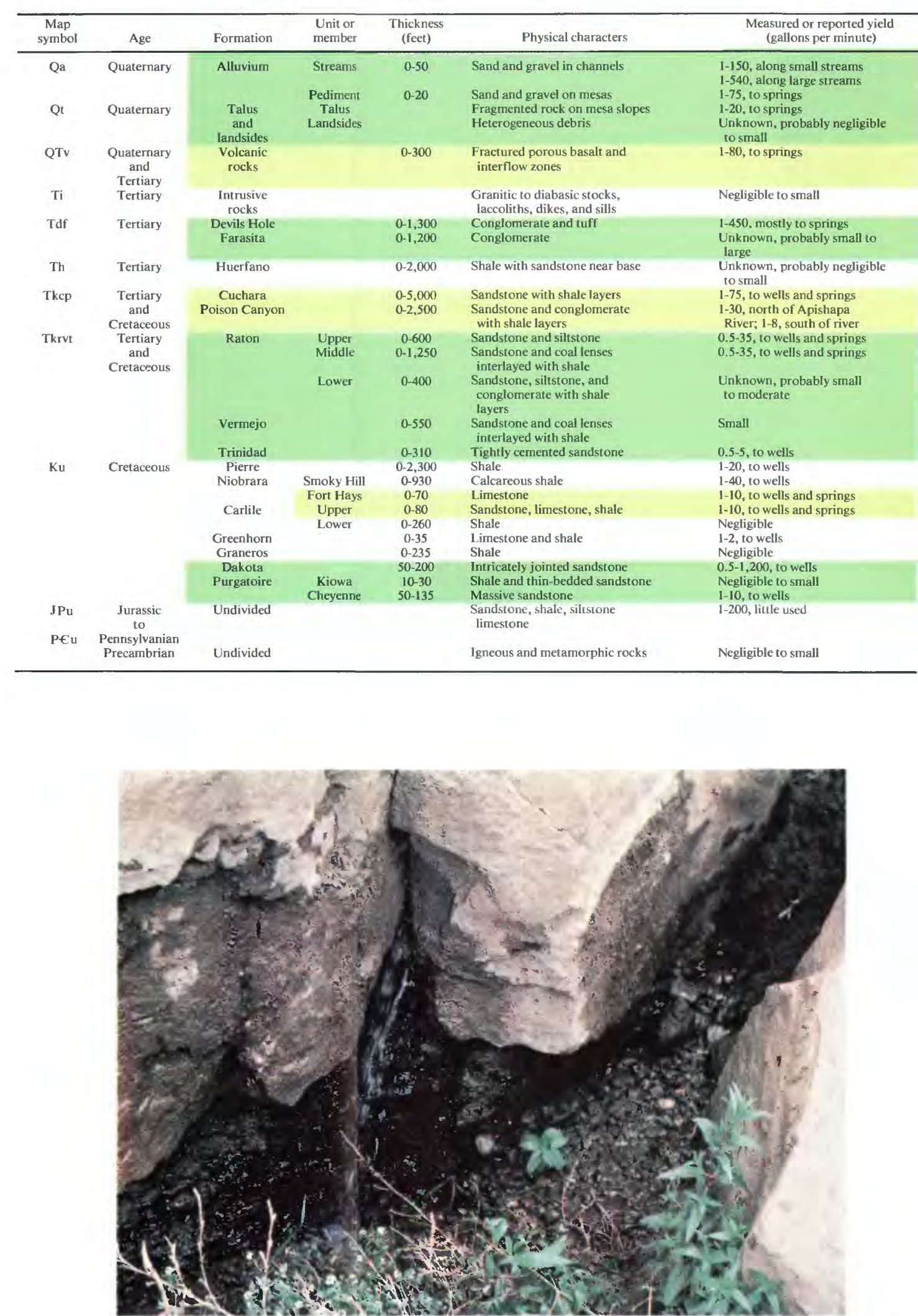
Figure 7.1-2 Spring issuing from fracture in sandstone lens, 


\subsection{GROUND WATER--Continued \\ 7.2 Depth to Ground Water}

\section{Ground Water Is Less Than 500 Feet Deep}

\section{Topography and geology control ground-water depths.}

The depth to ground water depends mostly on the topographic position of the well. In stream valleys, ground water is less than 100 feet deep because the valleys intercept ground water flowing through the bedrock (fig. 7.2-1). Some of this water discharges as springs or flows into stream alluvium. The alluvium also stores and transmits water infiltrating from precipitation and storm and snowmelt runoff. In Area 61, the alluvium is saturated to as much as 20 feet above the bedrock near the streams and much less on the edges of valleys. Springs discharge from the alluvium where the underlying bedrock is near the surface or where dikes and sills cross the channels. On stream divides, permeable formations are drained by seeps and springs discharging into the valleys, and wells may have to be drilled as much as 500 feet deep to obtain water. In figure 7.2-2, which shows the depth to ground water in a part of the area for which data are available, areas of shallow ground water generally coincide with valleys, and areas of deep ground water generally coincide with stream divides.

The depth to ground water also is affected by the geology. An extensive area of shallow ground water north of the Apishapa River (fig. 7.2-2) coincides with outcrop areas of the very permeable CucharaPoison Canyon aquifer (fig. 7.2-3). Clusters of springs shown in figure 7.2-3 indicate other areas where ground water is relatively shallow. Many of the springs shown in figure 7.2-3 are located at or near the contact between the Cuchara-Poison Canyon and Raton-Vermejo-Trinidad aquifers; most others are located on the slopes of volcanic-capped mesas, along dikes and sills, and in the axial region of the La Veta Syncline. The contact between the Cuchara-Poison Canyon and Raton-VermejoTrinidad aquifers localizes spring flow because water descending through loosely consolidated sandstone of the Cuchara-Poison Canyon aquifer perches above tightly cemented sandstone and siltstone of the Raton-Vermejo-Trinidad aquifer. Similarly, many springs are located on the slopes of volcanic capped mesas where water descending through the volcanic rocks perches at the contact with less permeable sedimentary rocks. Dikes and sills cause springs to develop because the intrusive rocks are barriers to flow, forcing water to the surface. Springs occur in the axial region of the La Veta Syncline because water in shallow flow systems tends to flow down the dip of permeable layers. 


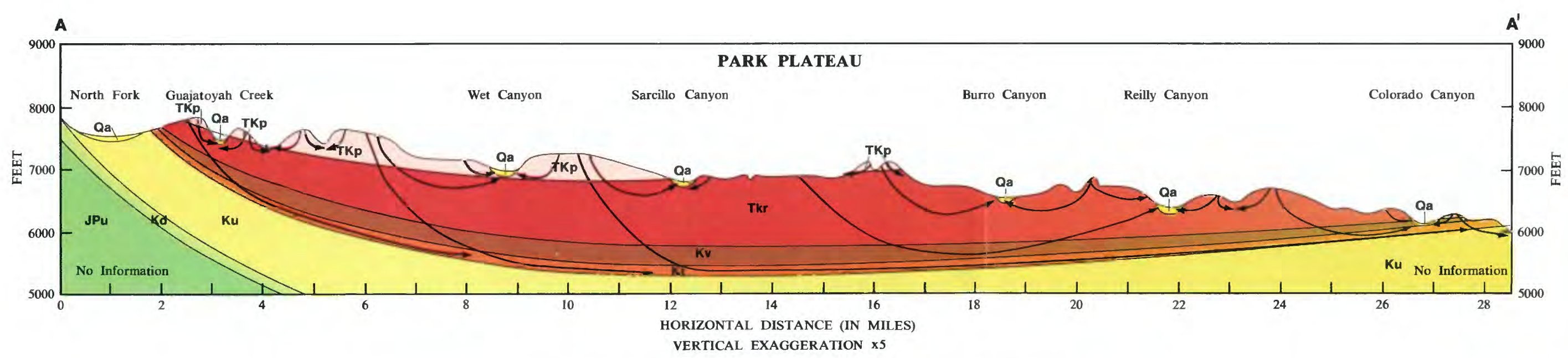

Figure 7.2-1 General direction of water flow across the Raton Basin.

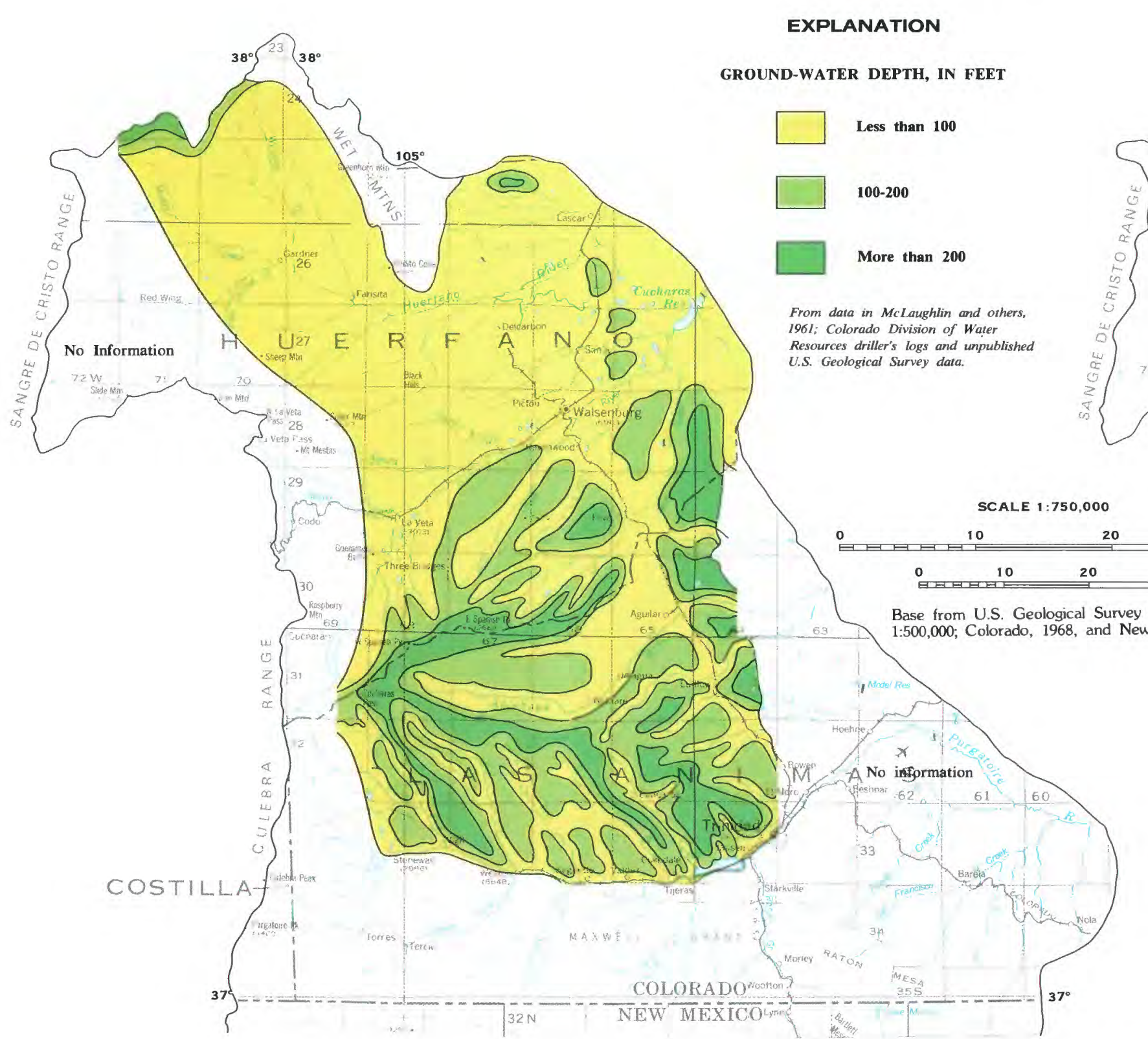

Figure 7.2-2 Expected depth to first ground-water in part of the Raton Basin.
EXPLANATION

FOR FIGURES 7.2-1 AND 7.2-3 FORMATIONS

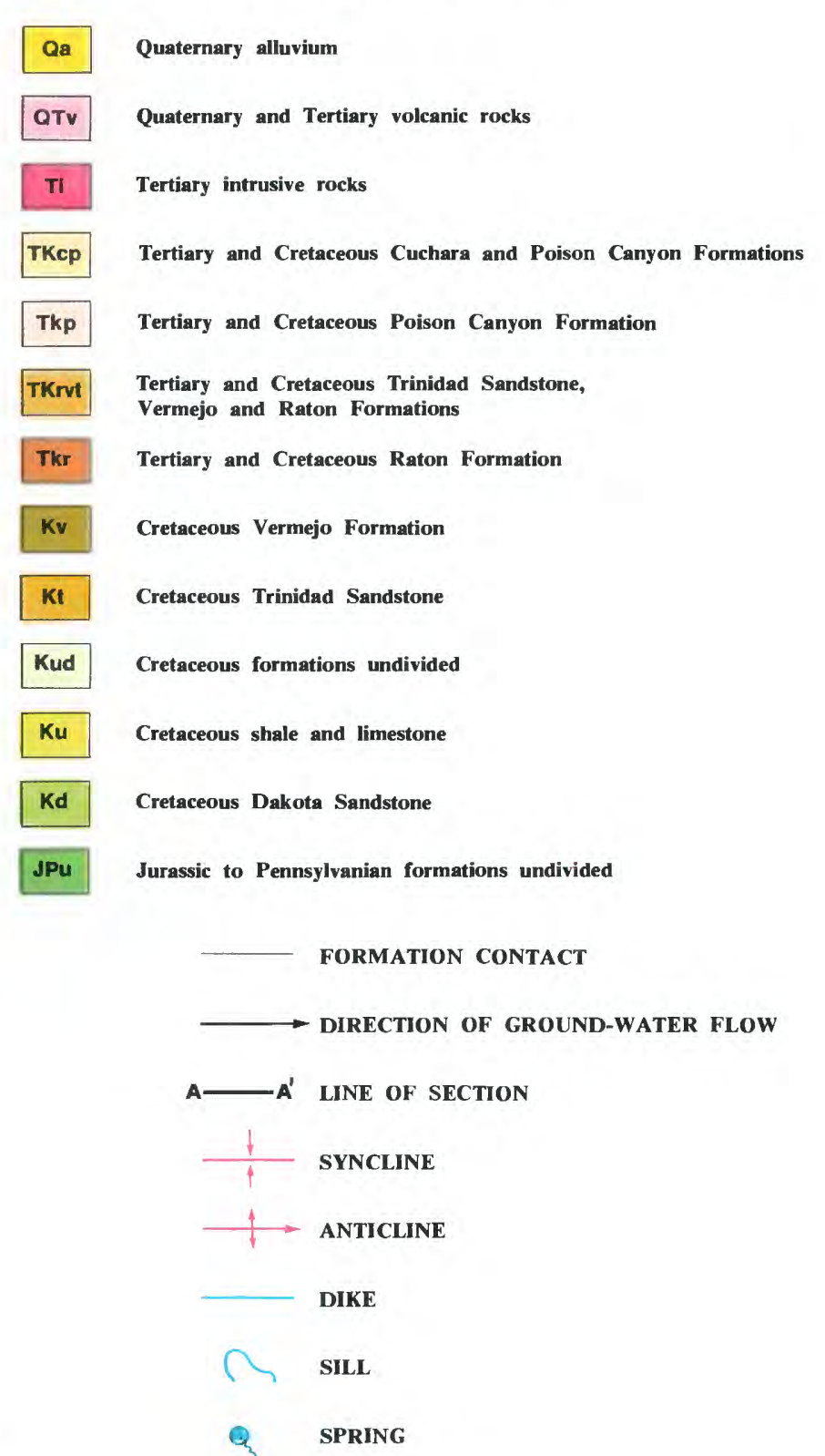

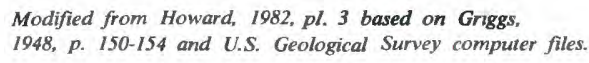




\title{
Water Levels in Wells Are Determined by Aquifer Properties and Indicate the Direction of Ground-Water Flow
}

\author{
The degree of aquifer confinement and the ability of an aquifer \\ to transmit water affect water levels in wells.
}

The difference in elevation between the water level and the producing horizon in a well indicates the degree of aquifer confinement. If an aquifer is confined between less permeable layers, ground water is under artesian pressure. The level to which water rises in a well penetrating a confined aquifer indicates the amount of artesian pressure in the aquifer. The artesian pressure in the Trinidad Sandstone increases from well $\mathrm{A}$ to wells $\mathrm{B}$ and $\mathrm{C}$ as the thickness of less permeable rocks overlying the Trinidad Sandstone increases (fig. 7.3-1). In Huerfano County, Colo., and Colfax County, N. Mex., water flows from wells drilled into the Dakota Sandstone through several hundred feet of impermeable Cretaceous shale (Griggs, 1948, p. 53; McLaughlin, 1966 , p. 65). In unconfined aquifers--that is, aquifers not overlain by less permeable formations, water is under atmospheric pressure, and water levels in wells coincide with the top of the zone of saturation (well D, fig. 7.3-1).

Area-wide contouring of water levels in an aquifer in any year produces a map that indicates the direction of regional ground-water flow. The regional flow in Area 61 is from west to east (fig. 7.3-2). However, little ground water discharges on the east side of the area because much of the water in the system is intercepted by stream valleys. In these valleys, water flowing through permeable layers and along fractures and faults discharges as springs where water-yielding rocks are exposed or flows into alluvium where the alluvium overlies the rocks. Deflections of ground-water level contours around stream valleys in figure 7.3-2 are caused by these local flow systems.
Water-level fluctuations in wells from year to year show the response of an aquifer to seasonal and annual variations in the availability of water. Graphs of ground-water fluctuations in wells penetrating the Cuchara-Poison Canyon aquifer, Raton-VermejoTrinidad aquifer, and alluvium are shown in figure 7.3-3. The well in the Cuchara-Poison Canyon aquifer is 143 feet deep, the well in the Raton-VermejoTrinidad aquifer is 62 feet deep, and the well in the alluvium is 26 feet deep. The Cuchara-Poison Canyon aquifer is confined--the other aquifers, unconfined. Annual fluctuations in water levels are greatest in the shallow, unconfined aquifers because these rocks receive water primarily by downward drainage from the surface and are, thus, affected more by precipitation cycles. These wells may go dry during prolonged drought. Because the recharge of water to confined aquifers is controlled primarily by the thickness of the overlying confining layer and the ability of the aquifer and confining layer to transmit water, water levels in wells penetrating deep confined aquifers respond less to precipitation cycles and usually fluctuate less than in unconfined aquifers.

Within confined aquifers, the water-level fluctuation in wells from year to year depends on variations in the pumping rate and the ability of the aquifer to transmit water. Water-level changes in the Raton-Vermejo-Trinidad aquifer near Trinidad, Colo., ranged from +5 to -23 feet from 1978 to 1981 (fig. 7.3-2). 


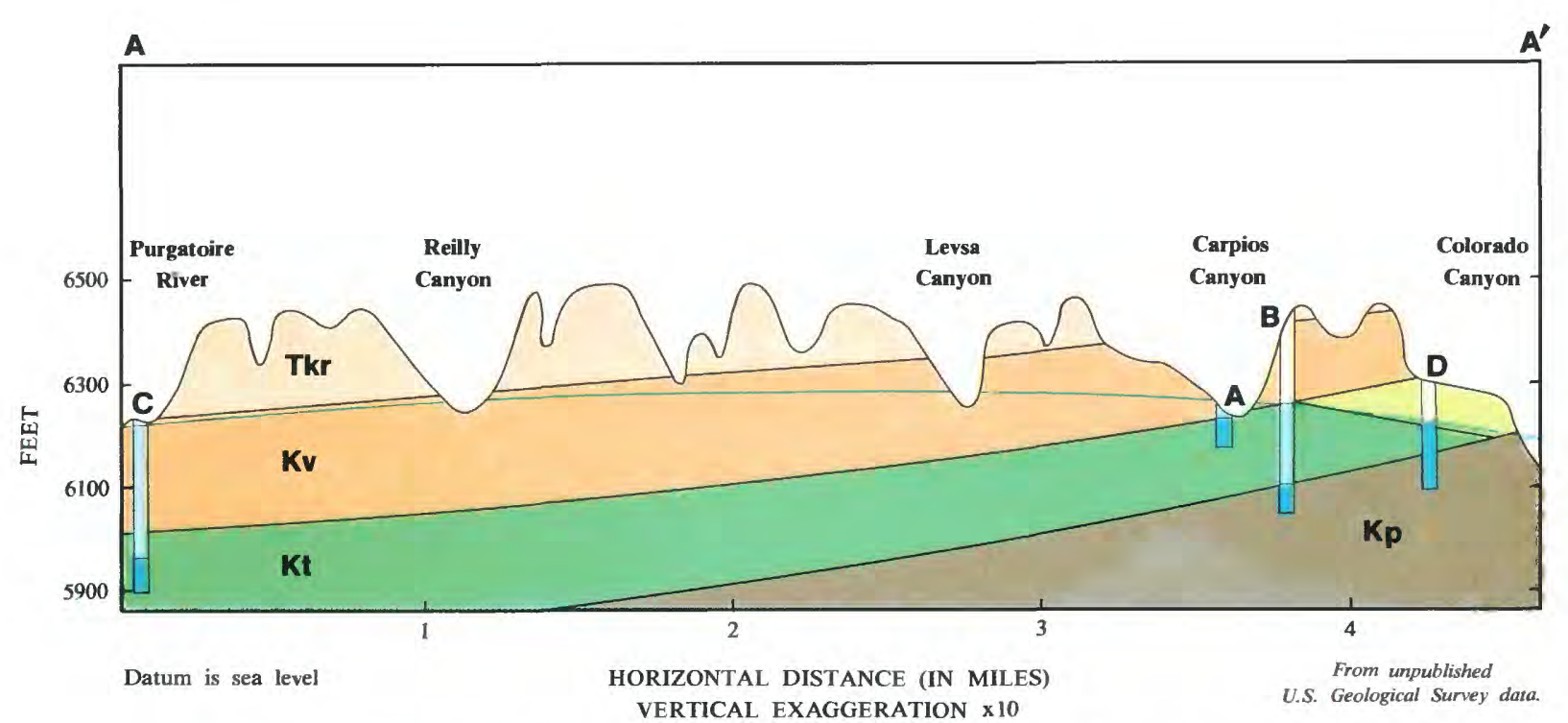

Datum is sea level

From unpublished
U.S. Geological Survey data
Figure 7.3-1 Geologic section showing water levels in Trinidad Sandstone, 1981

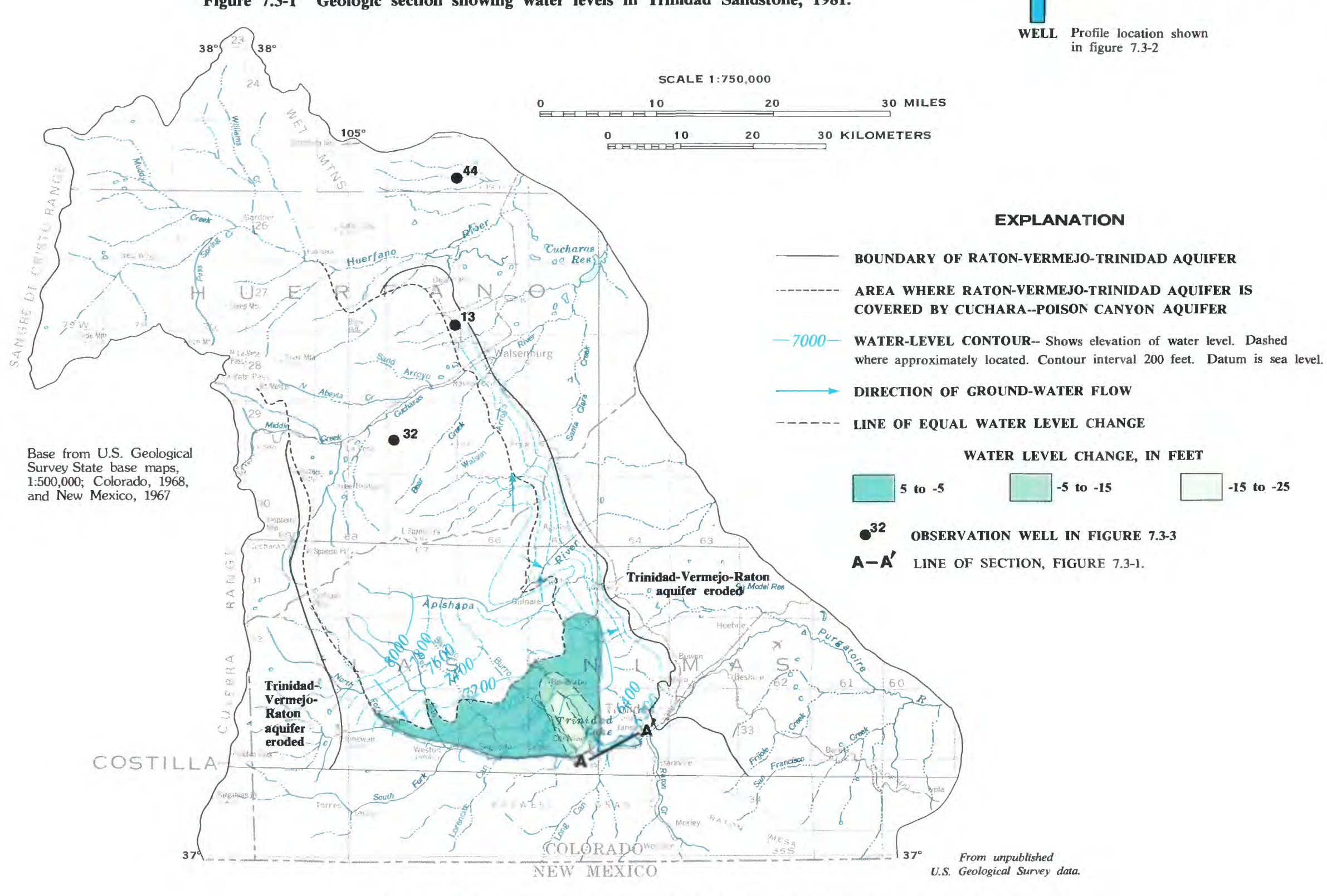

Figure 7.3-2 1981 water levels in the Raton-Trinidad-Vermejo aquifer and changes

DEPTH TO PRODUCING ZONE
EXPLANATION

Kv Vermejo Formation

Kt Trinidad Sandstone, confined

Kt Trinidad Sandstone, unconfined

Kp Pierre Shale

FORMATION CONTACT

GROUND-WATER LEVEL SURFACE

WATER LEVEL
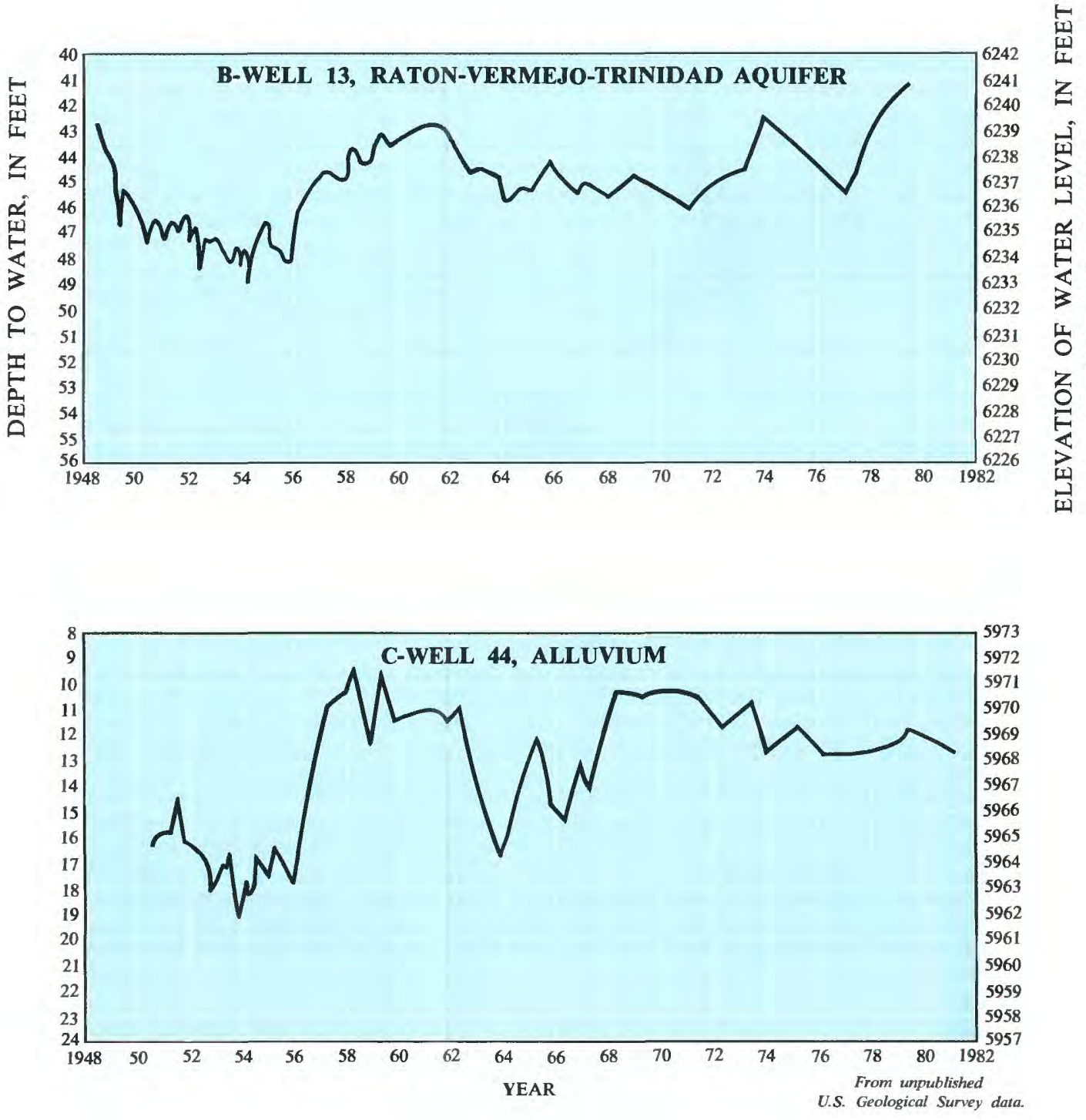

Figure 7.3-3 Water levels in observation wells, 1948-82.

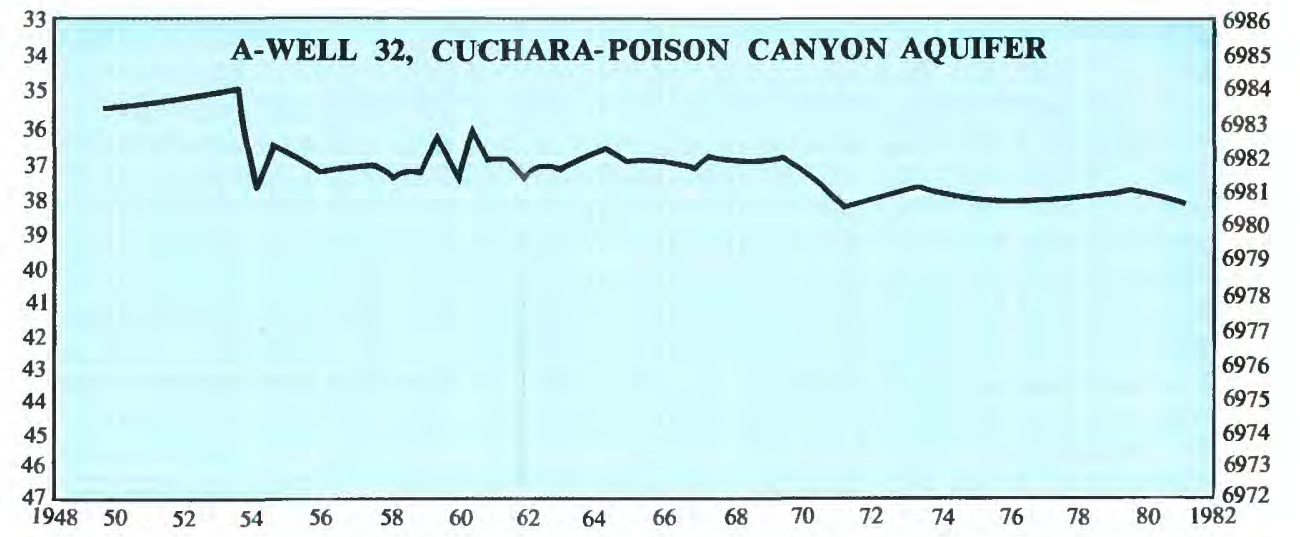




\title{
7.0 GROUND WATER--Continued \\ 7.4 Aquifer Tests
}

\section{Aquifer Tests Reveal Differences in Aquifer Permeability}

\author{
The alluvium is a more permeable aquifer than the bedrock.
}

\begin{abstract}
Aquifer tests (fig. 7.4-1) measure the ability of a formation to transmit water. The results of aquifer tests in Area 61 are summarized in table 7.4-1.

The specific capacity of a well is the discharge divided by the drawdown of the water level in the well during pumping, as expressed in gallons per minute per foot of drawdown. Where wells are constructed similarly, aquifers with greater permeability, such as the alluvium, have greater specific capacities than aquifers with less permeability, such as the Raton-Vermejo-Trinidad aquifer. The small specific capacity of the Cuchara-Poison Canyon aquifer indicated in table $7.4-1$ results because the formations comprising this aquifer are saturated only near the base in the area where the tests were performed. Such aquifers have small specific capacities because they have little water in them and are rapidly drained by pumping, even if they are known to be highly permeable, as in the case of the CucharaPoison Canyon aquifer.
\end{abstract}

The hydraulic conductivity is the rate at which ground water moves through a unit cross-sectional area of an aquifer under a unit hydraulic gradient, as expressed in feet per day. The data in table 7.4-1 indicate that ground water may move more easily in the alluvium than in the bedrock, and that ground water in the Raton-Vermejo-Trinidad aquifer moves at about the same rate through coal and sandstone. The apparently large rate of ground-water movement through siltstone and shale in the Raton-VermejoTrinidad aquifer is misleading because of a disproportionately large hydraulic-conductivity measurement in one 2 -foot- thick zone of fractured siltstone. Tests of shale and siltstone in the Raton-VermejoTrinidad aquifer usually show these rocks to be nearly impermeable.

The transmissivity is the hydraulic conductivity of an aquifer multiplied by its saturated thickness and is an indication of the volume of water that an aquifer can transmit, as expressed in feet squared per day. Equal transmissivities can result from a thick aquifer with small hydraulic conductivity or a thin aquifer with large hydraulic conductivity. The data in table 7.4-1 indicate that the alluvium can transmit much more water than bedrock, that fracturing can increase the transmissivity of a bedrock aquifer, and that in the Raton-Vermejo-Trinidad aquifer, coal and sandstone have about the same transmissivity.

Aquifer test data are contained in Griggs (1948), Dames and Moore (1978), Water, Waste, and Land, Ltd. (1980), Howard (1982), Colorado Water Resources Division drillers' logs, and unpublished U.S. Geological Survey data. 


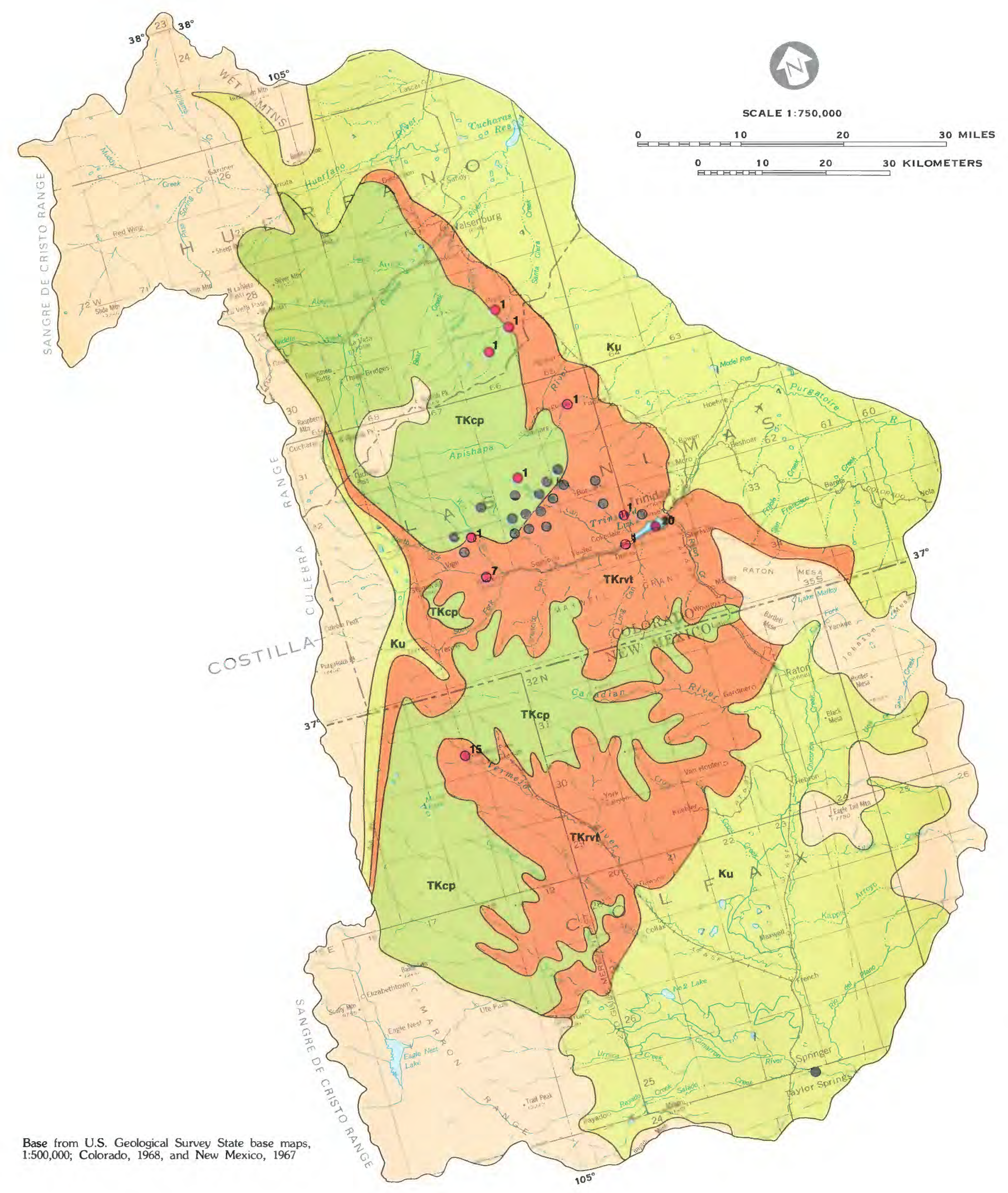

EXPLANATION

\section{FORMATIONS}

TKcp Cuchara-Poison Canyon

TKrvt Raton-Vermejo- Trinidad

Ku Cretaceous undivided

Undifferentiated rocks
- 15 HYDRAULIC-CONDUCTIVITY AND TRANSMISSIVITY TEST--number of tests shown by symbol

- SPECIFIC-CAPACITY TEST ONLY--Som tests are not located because of scale limitations or lack of precisely specified locations

7.41 Strangy of aquertest data

\begin{tabular}{|c|c|c|c|c|c|c|c|c|c|}
\hline \multirow[b]{2}{*}{ Aquifer } & \multicolumn{3}{|c|}{$\begin{array}{l}\text { Specific capacity } \\
\text { (gallons per minute } \\
\text { per foot) }\end{array}$} & \multicolumn{3}{|c|}{$\begin{array}{l}\text { Hydraulic conductivity } \\
\text { (feet per day) }\end{array}$} & \multicolumn{3}{|c|}{$\begin{array}{l}\text { Transmissivity } \\
\text { (feet squared per day) }\end{array}$} \\
\hline & $\begin{array}{l}\text { Number } \\
\text { of tests }\end{array}$ & Range & Mean & $\begin{array}{l}\text { Number } \\
\text { of tests }\end{array}$ & r Range & Mean & $\begin{array}{c}\text { Number } \\
\text { of tests }\end{array}$ & Range & Mean \\
\hline Alluvium & 2 & 6.4-24 & 15.2 & 10 & $\begin{array}{l}0.014- \\
1,880\end{array}$ & 198 & 9 & $\begin{array}{c}0.16- \\
570\end{array}$ & 929 \\
\hline Poison Canyon & 2 & $\begin{array}{l}.007- \\
.056\end{array}$ & .032 & & --No tests-- & & & --No tests-- & \\
\hline $\begin{array}{l}\text { Raton-Vermejo- } \\
\text { Trinidad }\end{array}$ & 17 & $\begin{array}{l}.006- \\
.43\end{array}$ & .11 & 40 & $0-45.4$ & 1.88 & 40 & $0-90.7$ & 10.4 \\
\hline $\begin{array}{l}\text { Coal and carbona- } \\
\text { ceous shale } \\
\text { Sandstone } \\
\text { Siltstone and shale }\end{array}$ & & $\begin{array}{l}\text { Not specif } \\
\text { Not specif } \\
\text { Not specif }\end{array}$ & & $\begin{array}{r}12 \\
14 \\
6\end{array}$ & $\begin{array}{l}0-5.66 \\
0-5.47 \\
0-45.4\end{array}$ & $\begin{array}{l}1.48 \\
.76 \\
7.74\end{array}$ & $\begin{array}{r}12 \\
14 \\
6\end{array}$ & $\begin{array}{l}0-38.0 \\
0-49.2 \\
0-90.7\end{array}$ & $\begin{array}{r}9.26 \\
8.11 \\
16.9\end{array}$ \\
\hline Dakota & 1 & .-. & 1.0 & & --No tests-- & & & --No tests-- & \\
\hline
\end{tabular}




\title{
Ground-Water Quality Deteriorates from West to East Across Area 61
}

\author{
The water quality deteriorates as water flows from sandstone, conglomerate, and \\ basalt in plateaus and mesas to shale in stream valleys and plains.
}

From west to east across the area, concentrations of dissolved solids increase and the ground water changes from bicarbonate to sulfate and chloride in composition (figs. 8.1-1 and 8.1-2). The regional chemical evolution of ground water is summarized in figure 8.1-3.

Area 61 is higher on the western side than on the eastern side (fig. 8.1-2), and as ground water flows down this topographic gradient, it gains dissolved solids by reaction with bedrock. Geologic formations on the western side of the area are predominantly sandstone and conglomerate, which consist of minerals, such as quartz, that resist reaction with ground water. Precipitation and surface water that infiltrate these rocks and become ground water are calcium bicarbonate solutions containing few dissolved solids. Because sandstone and conglomerate minerals do not react readily with ground water, the ground water is little changed as it flows through the rock. Geologic formations on the eastern side of the area are predominantly shale, which is composed of clay minerals and salts that react readily with ground water. Ground water flowing through shale thus becomes very mineralized. In the central part of the area, geologic formations consist of nearly equal quantities of sandstone and shale, and ground water there is intermediate in composition and quality between ground waters on the western and eastern sides of the area.

Regional trends in ground-water quality are disrupted by topographic and geologic features. As ground water flows from stream divides to stream valleys, it gains dissolved solids (fig. 8.1-2). Human activities, such as mining or irrigated agriculture, also add dissolved solids to ground water in valleys. Ground water in valleys with intermittent or ephemeral streams is thus more mineralized than in stream-divide areas. In valleys with perennial streams, the streamflow may be sufficient to flush out dissolved minerals and cause water in alluvium and shallow bedrock to be less mineralized than in adjacent bedrock. Ground water in volcanic-capped mesas contains few dissolved solids because the volcanic rocks are very permeable and rapidly transmit water. The origin of highly mineralized sodium chloride ground water near the Spanish Peaks, an intrusive stock, and related dikes is obscure, but the composition of the ground water may result from reactions with gases emanating from the igneous rocks.

Geologic formations are distinguishable by their ground-water quality. The Devils Hole-Farasita, $\mathrm{Cu}-$ chara Poison Canyon, and volcanic rock aquifers contain mostly calcium bicarbonate water with less than 500 milligrams per liter of dissolved solids. The Huerfano Formation contains mostly calcium sulfate water with 500 to 1,500 milligrams per liter of dissolved solids. The Raton-Vermejo-Trinidad aquifer contains mostly sodium bicarbonate water with 500 to 1,500 milligrams per liter of dissolved solids. Cretaceous shale, limestone, and sandstone contain mostly sodium sulfate, calcium sulfate, and sodium chloride water with 1,000 to more than 5,000 milligrams per liter of dissolved solids. Within each formation, water generally is least mineralized in topographically high areas and more mineralized in topographically low areas.

Sources of ground-water quality data include Griggs (1948, p. 159-176), Powell (1952, p. 30), McLaughlin and others (1961, p. 17-18), Dinwiddie (1964, p. 15), Hart and Smith (1979, p. 50-51), Water, Waste, and Land, Ltd. (1980, appendix E), Repplier and others (1981, pl. 5), Howard (1982, appendix K), Kaiser Steel Corp. (written commun., 1981), and unpublished U.S. Geological Survey data. 

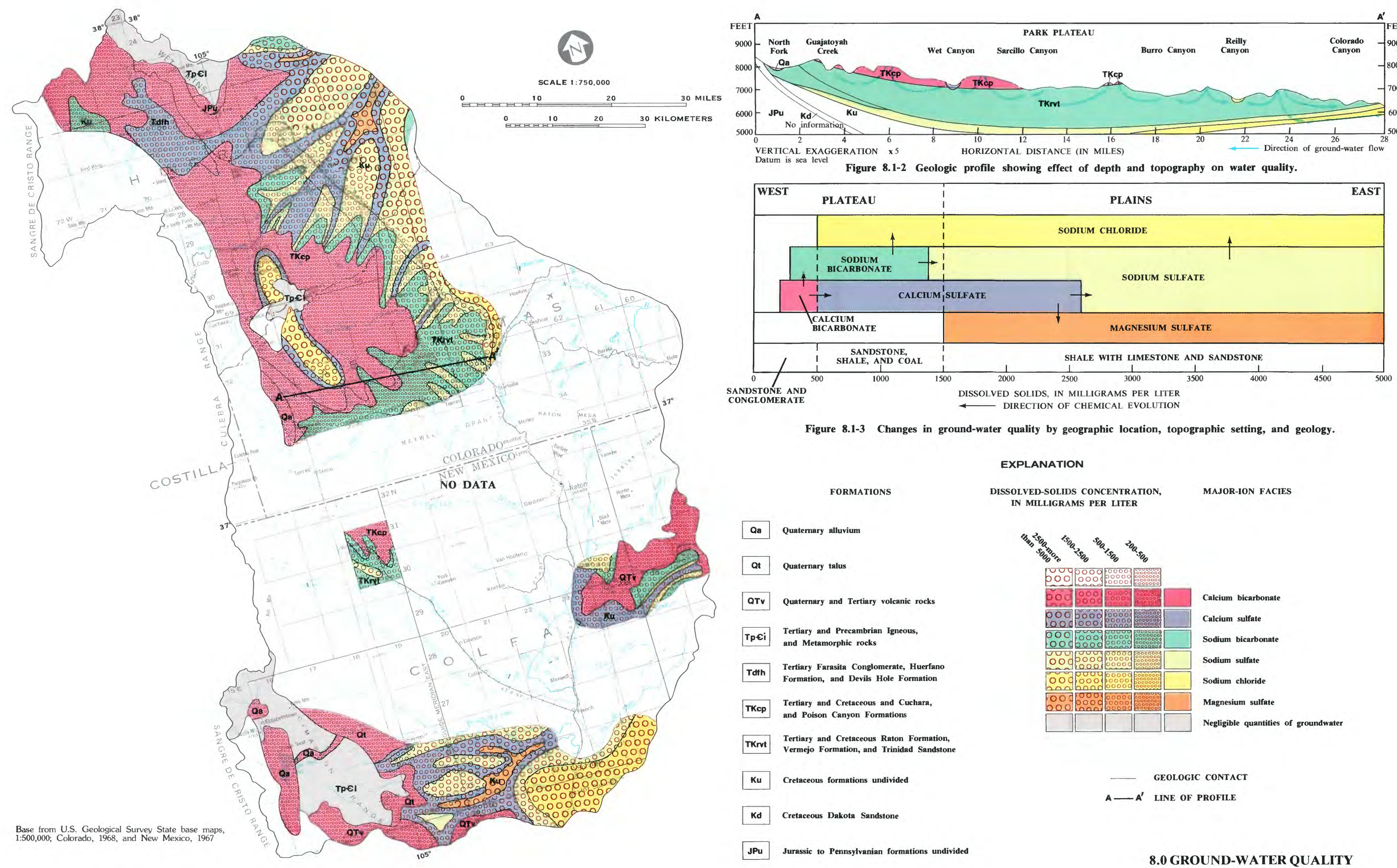

Figure 8.1-3 Changes in ground-water quality by geographic location, topographic setting, and geology.

\section{EXPLANATION}

FORMATIONS

Qa Quaternary alluvium

at Quaternary talus

QTv Quaternary and Tertiary volcanic rocks

\begin{tabular}{|l|l}
\hline TpEi Tertiary and Precambrian Igneous. \\
and Metamorphic rocks
\end{tabular}

Tdth Tertiary Farasita Conglomerate, Huerfano
Formation, and Devils Hole Formation

TKco Tertiary and Cretaceous and Cuchar

Tertiary and Cretaceous Raton Formation,
Vermejo Formation, and Trinidad Sandstone

$\mathrm{Ku}$ Cretaceous formations undivided

Kd Cretaceous Dakota Sandstone

JPu Jurassic to Pennsylvanian formations undivided
Dissolvid SOLIDS CONCENTRATION,

MAJOR-ION FACIES

\section{IN MILLIGRAMS PER LITER}

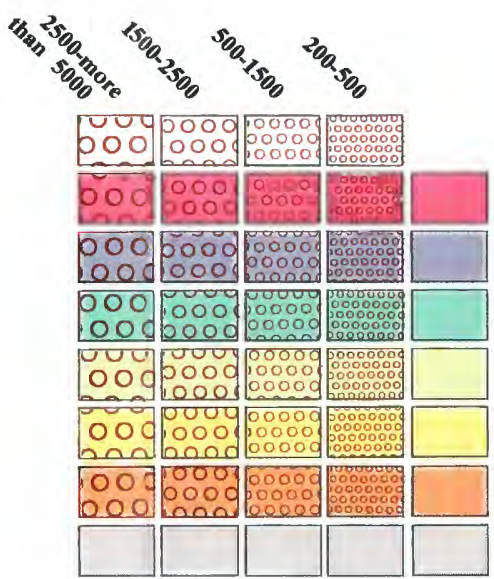

Calcium bicarbonat

Calcium sulfate

Sodium bicarbonat

Sodium sulfate

Sodium chloride

Magnesium sulfate

Negligible quantities of groundwater

$$
\begin{aligned}
& \text { GEOLOGIC CONTAC } \\
& \text { A- } A^{\prime} \quad \text { LINE OF PROFILE }
\end{aligned}
$$
8.0 GROUND-WATER QUALITY 


\author{
8.0 GROUND-WATER QUALITY--Continued \\ $8.2 \mathrm{pH}$ and Specific Conductance
}

\title{
pH and Specific Conductance Vary Among and Within Aquifers
}

\author{
$\mathrm{pH}$ and specific conductance are easily measurable properties of ground water \\ that allow estimates of the acidity and dissolved-solids concentration.
}

The $\mathrm{pH}$ of water is a measure of acidity. $\mathrm{A} \mathrm{pH}$ of less than 7.0 is acidic; 7.0 is neutral; more than 7.0 is alkaline. Information on the $\mathrm{pH}$ of ground water is sparse. The $\mathrm{pH}$ of ground water in areas where it is known or can be reasonably inferred from existing data is shown in figure 8.2-1. The $\mathrm{pH}$ of ground water in wells and springs ranges from 6.6 to 9.3 . Marked variations in $\mathrm{pH}$ occur within distances of less than a mile. Variations in $\mathrm{pH}$ cannot be correlated with ratios of sulfate to bicarbonate or chloride to bicarbonate.

Ground water in Cretaceous to Tertiary transitional and terrestrial formations is more alkaline than in Cretaceous marine formations. The $\mathrm{pH}$ of ground water in the coal-bearing Vermejo and Raton Formations most commonly ranges from 7.5 to 8.0 , but it exceeds 8.0 in the vicinity of some active or abandoned coal mines. However, it cannot be proven that mining raises the $\mathrm{pH}$ of ground water since the $\mathrm{pH}$ of mine discharge, ranging from 7.3 to 9.2 , is in the same range as that of ground water from undisturbed bedrock. The $\mathrm{pH}$ of ground water in the Cuchara and Poison Canyon Formations most commonly ranges from 7.5 to 8.0 north of the Spanish Peaks and 6.5 to 7.5 south of the Spanish Peaks. The $\mathrm{pH}$ of ground water in the Devils Hole and Huerfano Formations, Farasita Conglomerate and Trinidad Sandstone most commonly ranges from 7.0 to 8.0 . The $\mathrm{pH}$ of ground water in Cretaceous marine formations most commonly ranges from 7.0 to 8.0 and tends to be slightly greater in shale than in limestone or sandstone.

Specific conductance is an indicator of dissolved-solids concentration; like $\mathrm{pH}$, it is an easily measured property of ground water that can be used to estimate water-quality characteristics which are more difficult and expensive to ascertain. Areas where the dissolved-solids concentration in ground water is known or can be reasonably inferred from analyses are shown in figure 8.2-2, and graphs of specific conductance versus dissolved-solids concentration prepared from these analyses are shown in figure 8.2-3. These graphs can be used to estimate the dissolved-solids concentrations in parts of Area 61 where chemical analyses are not available. From figure $8.2-3$, it can be seen that for any specific conductance the dissolved-solids concentrations generally will be greatest in shale and limestone formations, less in shale and sandstone formations, and least in sandstone formations and alluvium.

The similarity of specific conductance/ dissolved-solids ratios in Purgatoire drainage alluvium and sandstone formations suggests that much of the water in the alluvium flowed in from sandstone. In the area sampled, the Purgatoire drainage is underlain by the Poison Canyon and Raton Formations, which contain sandstone and shale. Specific conductance/dissolved-solids ratios indicate that water from these formations is transmitted principally by the sandstone layers. 


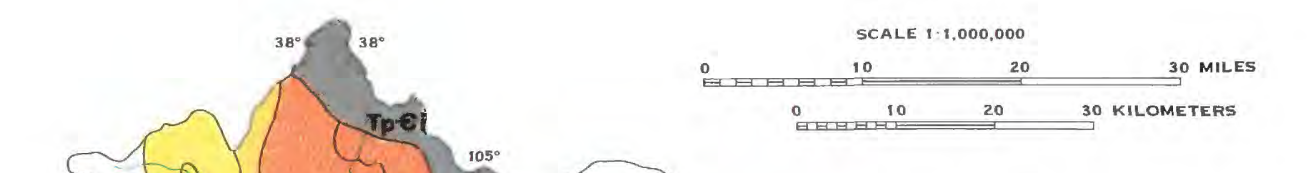

2

$3_{3}^{\text {Tah }}$

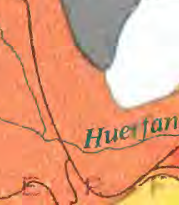

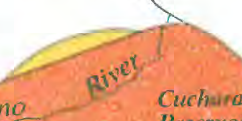
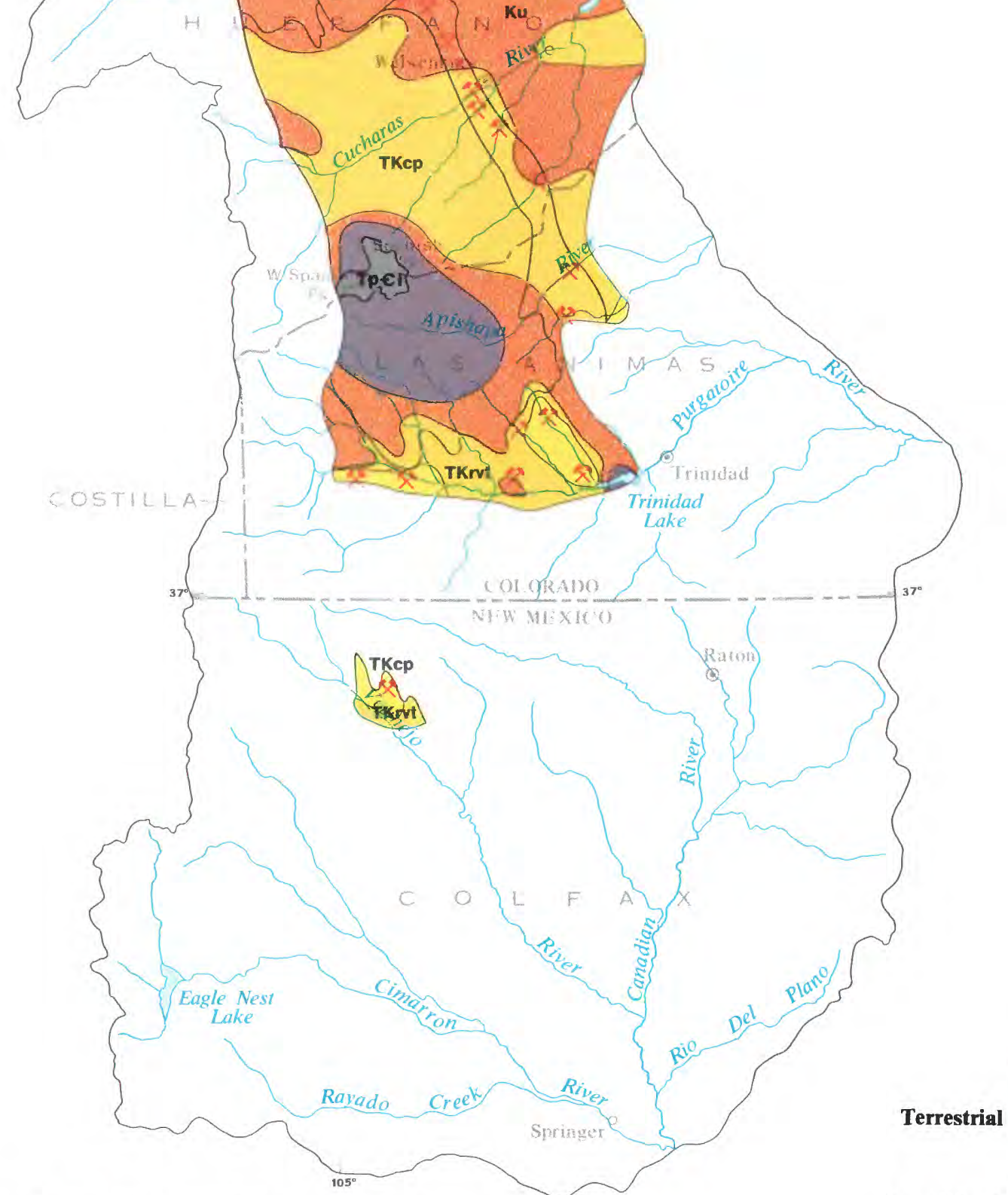

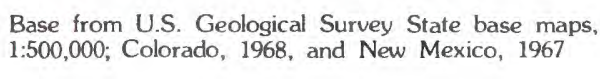

Transitional - TKMt Tertiary and Cretaceous Raton Formation,

Marine $-\mathrm{Ku}$ Cretaceous shale and limestone

Tertiary and Precambrian Igneous,
and Metamorphic rocks

Figure 8.2-1 $\mathrm{pH}$ of water from wells less than 400 feet deep. and Dakota Sandstone

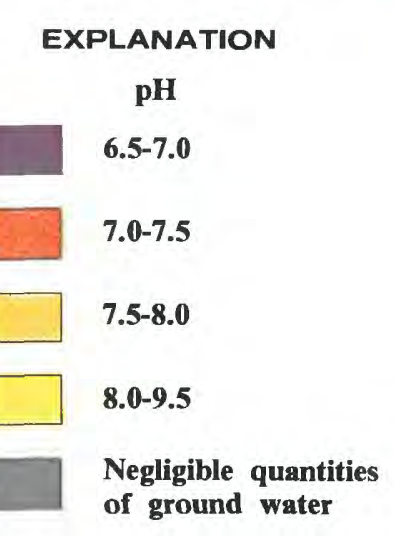

GEOLOGIC FORMATIONS

\section{GEOLOGIC CONTACT}

L LOCATION OF COAL MINE

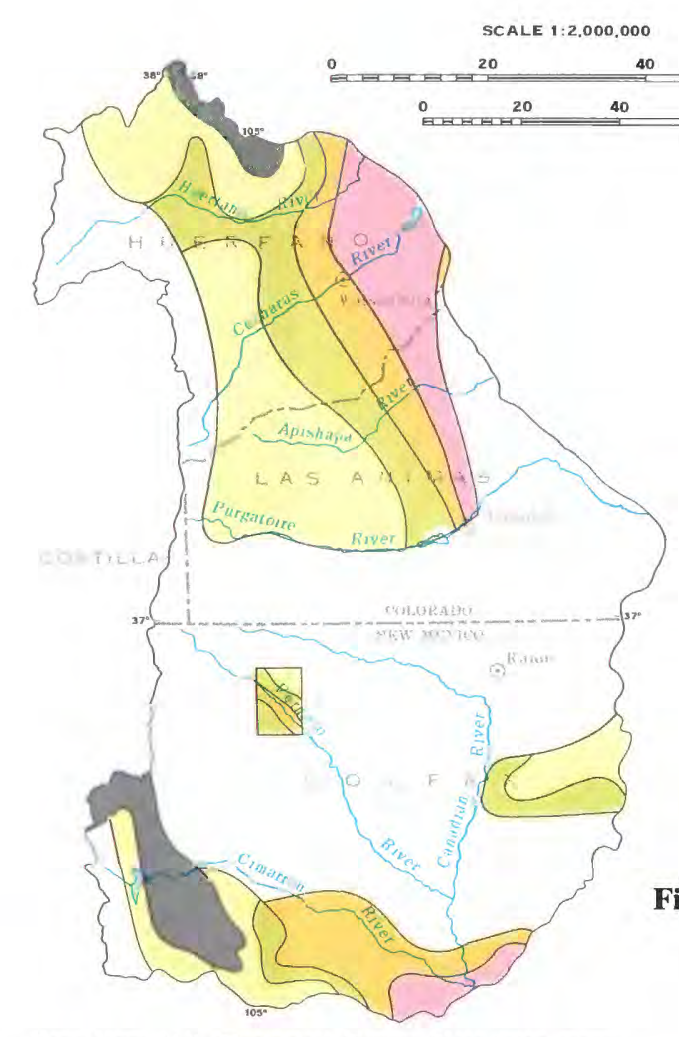

60 MLES

EXPLANATION

DISSOLVED SOLIDS, IN MILLIGRAMS PER LITER

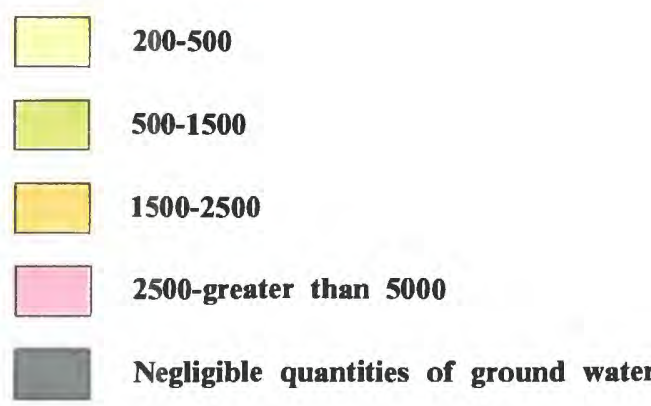

igure 8.2-2 Dissolved-solids concentration in water from wells less than 400 feet deep

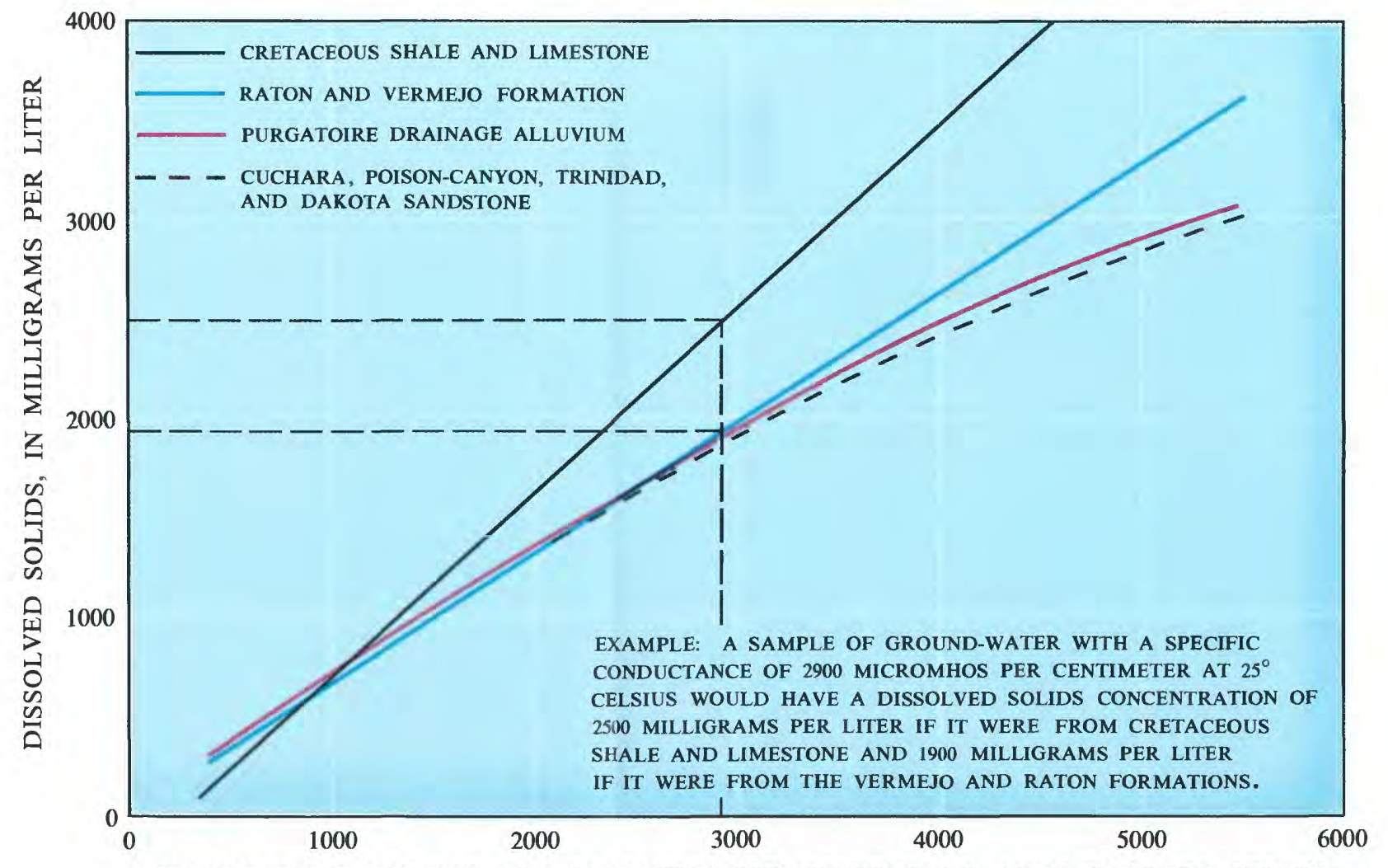

SPECIFIC CONDUCTANCE, IN MICROMHOS PER CENTIMETER AT 25 DEGREES CELSIUS

Figure 8.2-3 Relation of dissolved solids to specific conductance. 


\title{
8.0 GROUND-WATER QUALITY--Continued
}

8.3 Minor Dissolved Constituents

\section{Concentrations of Several Minor Dissolved Constituents Exceed Water-Quality Standards}

\author{
Concentrations of boron, fluoride, iron, manganese, mercury, nitrate nitrogen, \\ selenium, and zinc are increased locally by geologic processes and \\ human activities.
}

Water-quality standards established by the U.S. Environmental Protection Agency (EPA) for human and livestock consumption and crop irrigation serve as a basis for appraisal of the concentrations of minor dissolved constituents (usually present in concentrations of less than 10 milligrams per liter) in terms of their limiting effects on the intended use of the water (table 8.3-1). Several studies in Area 61 considered minor dissolved constituents in the ground water, but the sampling was sparse and the selection of analyzed constituents was inconsistent from study to study. Minor dissolved constituents that were analyzed include aluminum, arsenic, boron, bromide, cadmium, copper, fluoride, iodide, iron, lead, manganese, mercury, molybdenum, nickel, nitrate-nitrogen, phosphate-phosphorus, selenium, silver, uranium, vanadium, and zinc. Concentrations of several of these constituents locally exceed EPA standards, in some instances by three to four times; the selenium concentration may be as much as 100 times the standard (figs. 8.3-1 and 8.3-2).

Abnormally high concentrations of minor dissolved constituents in ground water result from the dissolution of uncommon minerals in bedrock, other hydrogeologic processes, or contamination from human activities. Large concentrations of fluoride occur in water in the Poison Canyon and Raton Formations probably as a result of the dissolution of detrital fluorite, a calcium fluoride mineral (Howard, 1982, p. 56-57). The coincident enrichment of fluoride and boron in water in the Cretaceous Dakota Sandstone near the southern edge of the area is a common occurrence in areas with thermal activity and suggests a local magmatic origin for these constituents (Griggs, 1948, p. 53-55). Large concentrations of iron and manganese occur principally in water in the Raton and Vermejo Formations, and also in the Poison Canyon Formation and alluvium, probably from the dissolution of coal, pyrite (an iron sulfide mineral), and siderite (an iron carbonate mineral) (Howard, 1982, p. 53-56). Large selenium concentrations occur principally in the Cretaceous Smoky Hill Marl Member of the Niobrara Formation in the northeastern corner of the basin and randomly in other formations as a result of the dissolution of selenium-containing salt minerals in shale. Nitratenitrogen enrichment in the ground water occurs in most formations, principally in stream valleys and the eastern plains where farming and ranching are the most common land uses. Animal wastes and fertilizers apparently add nitrogen to the ground water, although some of the nitrogen enrichment may result from the dissolution of organic-rich shale or other rocks with large nitrogen contents. Large mercury and zinc concentrations in ground water occur randomly and cannot be attributed to specific origins.

Table 8.3-1 Water-quality standards.

\begin{tabular}{lcc}
\hline Constituent & $\begin{array}{c}\text { Recommended } \\
\text { Concentration Limit } \\
\text { (milligrams per liter) }\end{array}$ \\
\hline Baron & 0.75 & Damages fruit and nut trees \\
Chloride & 250 & Kills fish \\
Fluoride & 1.8 & Mottles teeth \\
Hardness (calcium and magnesium as calcium carborate) & 120 & Inhibits sudsing and encrusts pipes \\
Iron & 0.3 & Imparts undesirable taste to water and stains laundry \\
Manganese & 0.05 & Same as iron effects \\
Nitrogen & 10 & Causes lethal blood disease in infants \\
Selenium & 0.01 & Causes gastrointestinal and skin damage and mental disorders \\
Sulfate & 250 & Causes laxative effect \\
Zinc & 5.0 & Imparts bitter taste to water and damages crops \\
\hline
\end{tabular}

1. Sources are Freeze and Cherry (1979, p. 386), U.S. Environmental Protection Agency (1977a, 1977b), and Hem, 1970, p. 224-226 


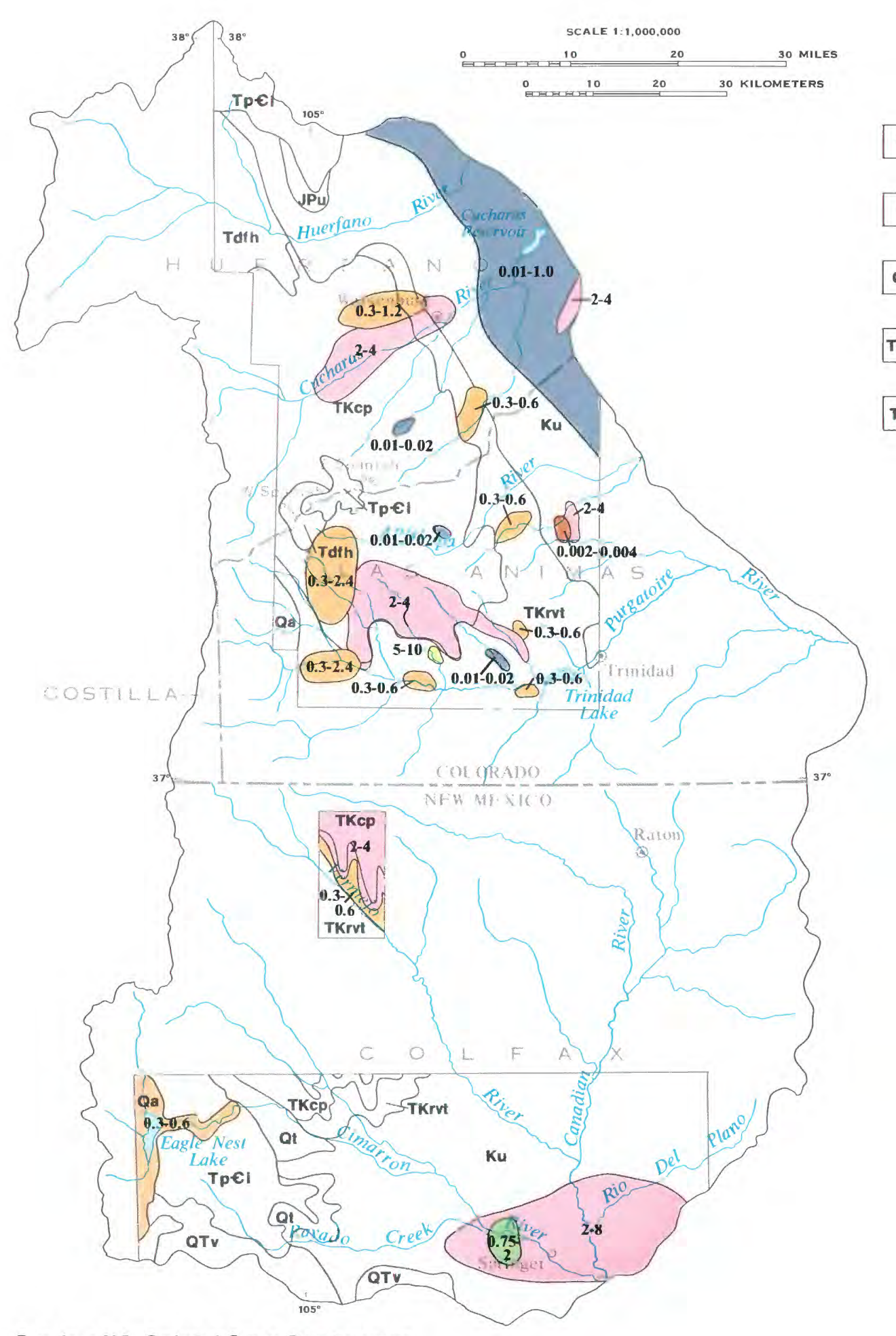

EXPLANATION

FORMATIONS SHOWN ON THE MAPS

aa Alluvium

at Talus

QTV Volcanic rocks

Igneous and metamorphic rock

Devils Hole Formation

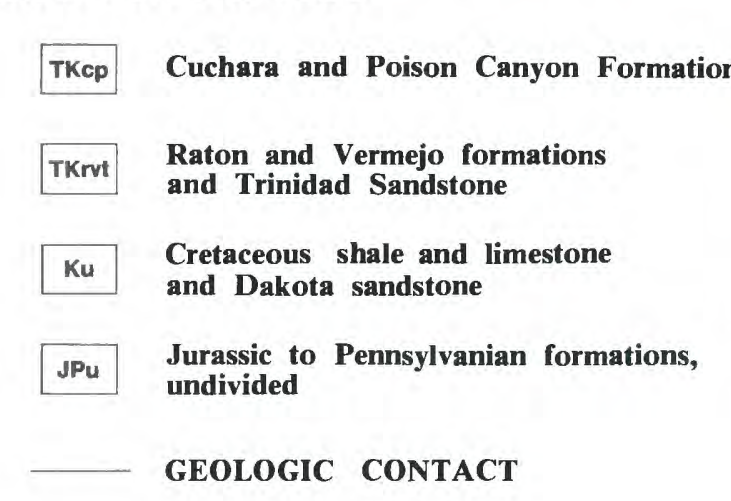
and Huerfano Formation

\section{EXPLANATION}

BORON

FLUORIDE

IRON AND MANGANESE

MERCURY

SELENIUM

ZINC

0.3-0.6 RANGE OF CONCENTRATION, LITER
EXPLANATION

NITRATE NITROGEN

CONCENTRATION,

PER LITER

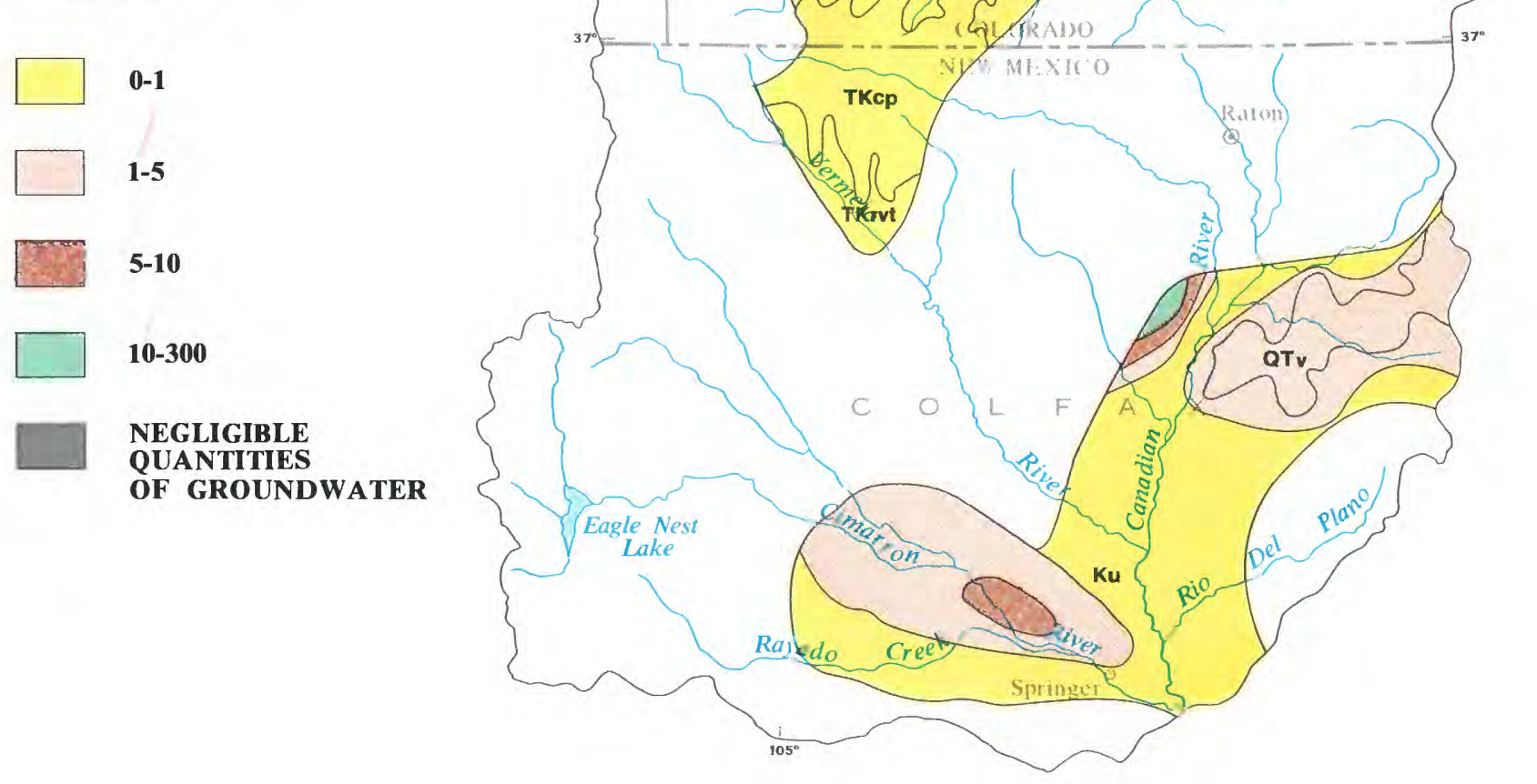

Figure 8.3-2 Nitrate-nitrogen concentrations in water from wells less than 400 feet deep. 


\title{
NAWDEX, WATSTORE, OWDC have Water Data Information
}

\author{
Water data are collected in coal areas by a large number of organizations in \\ response to a wide variety of needs.
}

Three activities within the U.S. Geological Survey help to identify and improve access to the vast amount of existing data.

(1) The National Water Data Exchange (NAWDEX) indexes the water data available from more than 400 organizations and serves as a central focal point to help those needing data to determine what information is available.

(2) The National Water Data Storage and Retrieval System (WATSTORE) serves as the central respository of water data collected by the U.S. Geological Survey and contains data on the quantity and quality of surface and ground water.
(3) The Office of Water Data Coordination (OWDC) coordinates Federal water-data acquisition activities and maintains a "Catalog of Information on Water Data." To assist in identifying available water-data activities in coal provinces of the United States, special indexes to the catalog are being printed and made available to the public.

More detailed explanations of these three activities are given in sections 9.2, 9.3, and 9.4. The availability of topographic maps covering Area 61 is discussed in section 9.5 . 


\author{
9.0 WATER-DATA SOURCES--Continued \\ 9.2 National Water-Data Exchange (NAWDEX)
}

\title{
NAWDEX Simplifies Access to Water Data
}

\author{
The National Water-Data Exchange (NAWDEX) is a nationwide program managed by \\ the U.S. Geological Survey to assist users of water data or water-related \\ data in identifying, locating, and acquiring needed data.
}

NAWDEX is a national confederation of wateroriented organizations working together to make their data more accessible and to facilitate a more efficient exchange of water data.

Services are available through a Program Office at the U.S. Geological Survey's National Center in Reston, Va., and a nationwide network of Assistance Centers in 45 States and Puerto Rico, which provide local and convenient access to NAWDEX facilities (fig. 9.2-1). A directory is available upon request that provides names of organizations and persons to contact, addresses, telephone numbers, and office hours for each of these locations [Director of Assistance Centers of the National Water-Data Exchange (NAWDEX), U.S. Geological Survey Open-File Report 80-1193].

NAWDEX can assist any organization or individual in identifying and locating water data and referring the requester to the organization that retains the data required. To perform this service, NAWDEX maintains a computerized Master WaterData Index (fig. 9.2-2) that identifies sites for which water data are available, the type data available for each site, and the organization retaining the data. A Water-Data Sources Directory (fig. 9.2-3) also is maintained that identifies organizations and the locations within these organizations from which data may be obtained. In addition, NAWDEX has direct access to some large water-data bases of its members and has reciprocal agreements for the exchange of services with others.

Charges for NAWDEX services are assessed at the option of the organization providing the requested data or data service. Search-assistance services are provided free by NAWDEX to the greatest extent possible. Charges are assessed, however, for those requests requiring computer cost, extensive personnel time, duplicating services, or other costs encountered by NAWDEX in the course of providing services.
Charges assessed by NAWDEX Assistance Centers will not exceed the direct costs incurred in responding to the data request. Estimates of cost are provided by NAWDEX upon request, however estimates will be automatically provided when costs are anticipated to be substantial.

For additional information concerning the NAWDEX program or its services contact:

Program Office

National Water Data Exchange (NAWDEX)

U.S. Geological Survey

421 National Center

12201 Sunrise Valley Drive

Reston, VA 22092

Telephone: (703) 860-6031

FTS 928-6031

Hours: $7: 45$ to $4: 15$ Eastern Standard Time

or

COLORADO

U.S. Geological Survey

Water Resources Division

MS 415 Box 25046 Denver Federal Center Lakewood, CO 80225

Telephone: (303) 234-5097

or

NEW MEXICO

U.S. Geological Survey

Water Resources Division

505 Marquette NW, Room 720

Western Bank Building

Albuquerque, NM 87102

Telephone: (505) 766-2430 


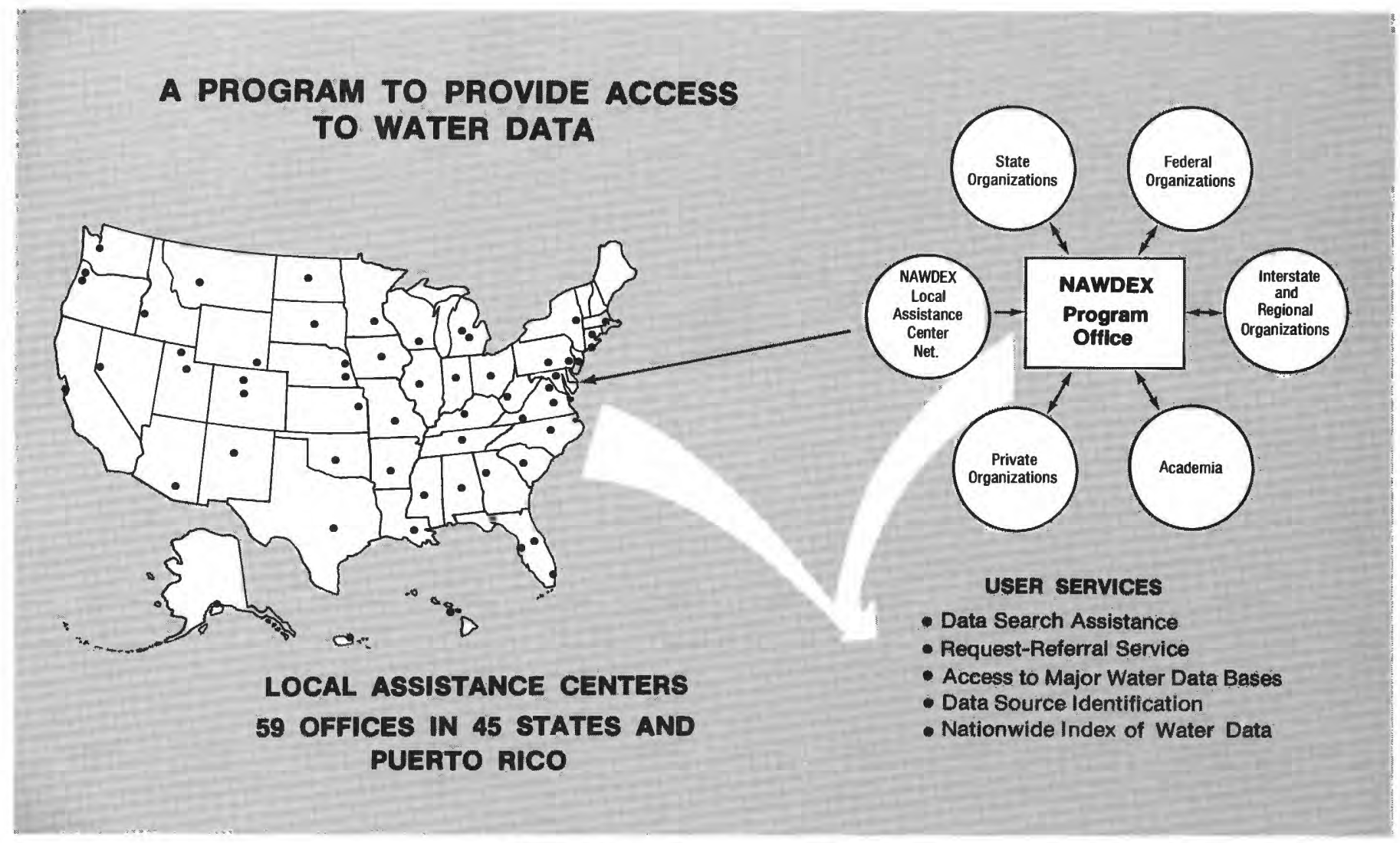

Figure 9.2-1 Access to water data.

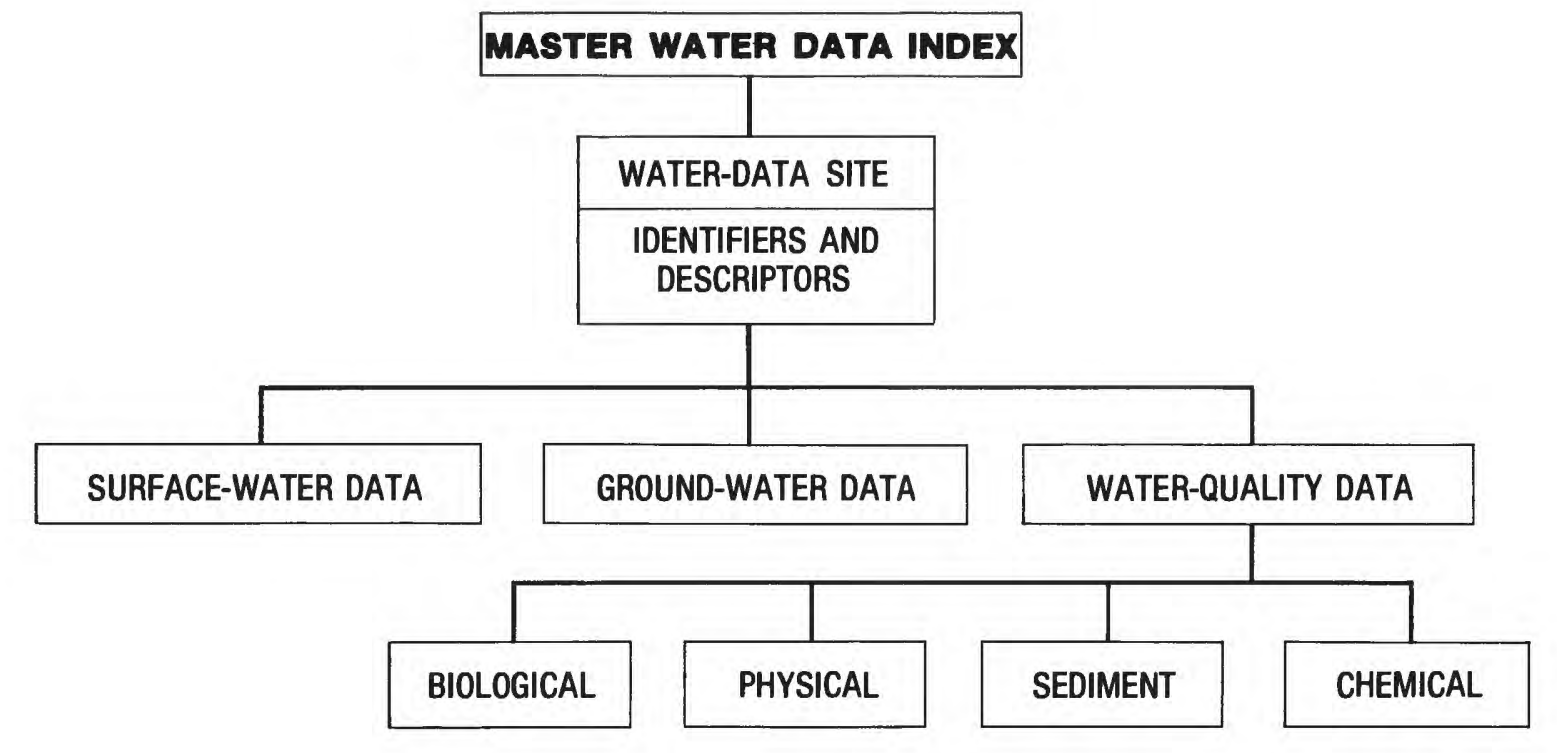

Figure 9.2-2 Master water-data index.

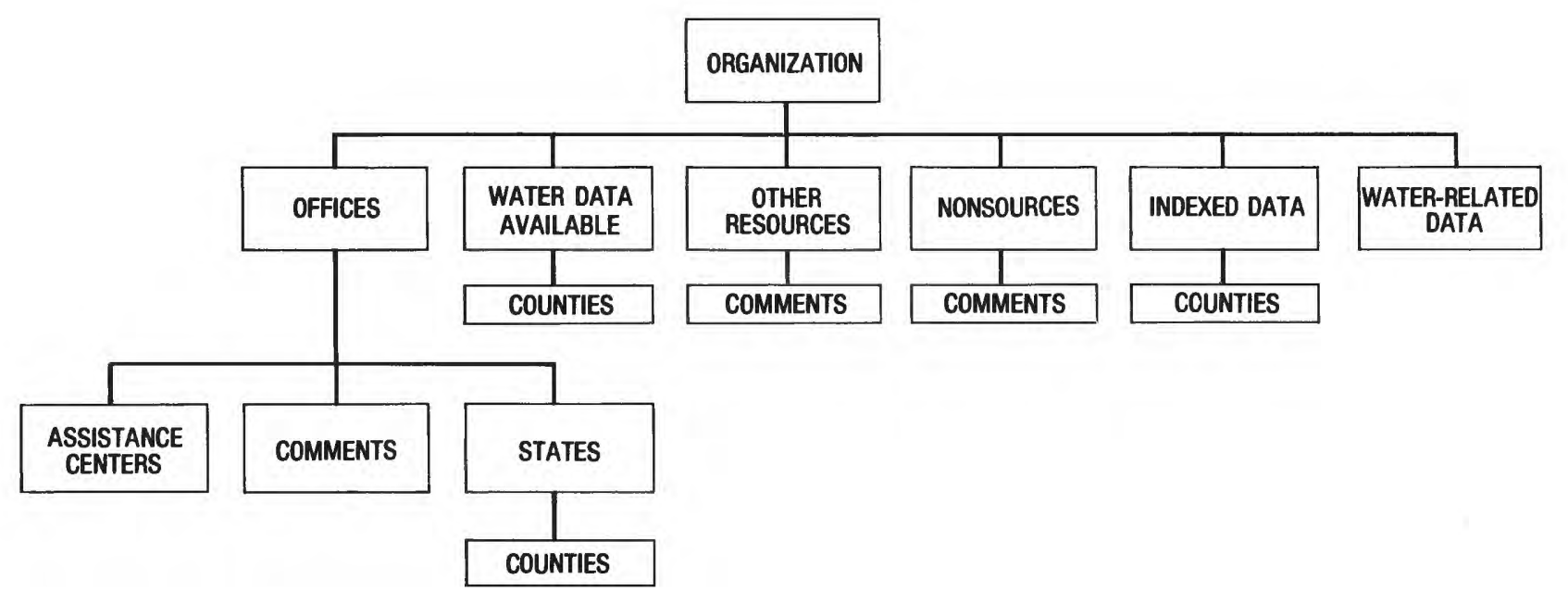

Figure 9.2-3 Water-data sources directory. 


\title{
9.0 WATER-DATA SOURCES--Continued 9.3 WATSTORE
}

\section{WATSTORE Automated System}

\author{
The National Water-Data Storage and Retrieval System (WATSTORE) of the U.S. \\ Geological Survey provides computerized procedures and techniques for \\ processing water data and provides effective and efficient management \\ of data-releasing activities.
}

The National Water-Data Storage and Retrieval System (WATSTORE) was established in November 1971 to computerize the U.S. Geological Survey's existing water-data system and to provide effective and efficient management of its data-releasing activities. The system is operated and maintained on the central computer facilities of the Survey at its National Center in Reston, Va. Data may be obtained from WATSTORE through the Water Resources Division's 46 district offices. General inquiries about WATSTORE may be directed to:

Chief Hydrologist

U.S. Geological Survey

437 National Center

Reston, VA 22092

or

\author{
District Chief \\ U.S. Geological Survey \\ Water Resources Division \\ MS 415 Box 25046 Denver Federal Center \\ Lakewood, CO 80225
}

or

\author{
District Chief \\ U.S. Geological Survey \\ Water Resources Division \\ P.O. Box 26659 \\ Western Bank Building \\ Albuquerque, NM 87125
}

The Geological Survey currently (1982) collects data at approximately 16,000 stream-gaging stations, 1,000 lakes and reservoirs, 5,200 surface-water quality stations, 1,020 sediment stations, 30,000 waterlevel-observation wells, and 12,500 ground-waterquality wells. Each year many water-data collection sites are added and others are discontinued; thus, large amounts of information, both current and historical, are amassed by the Survey's data-collection activities.

The WATSTORE system consists of several files in which data are grouped and stored by common characteristics and data-collection frequencies. The system also is designed to allow for the inclusion of additional data files as needed. Currently, files are maintained for the storage of: (1) surface-water, water-quality, and ground-water data measured daily or continuously; (2) annual peak values for streamflow stations; (3) chemical analyses for surface- and ground-water stations; (4) water parameters measured more frequently than daily; and (5) geologic and inventory data for ground-water stations. In addition, an index file of stations for which data are stored in the system is also maintained (fig. 9.3-1). A brief description of each file is as follows:

Station-Header File: All sites for which data are stored in the Daily Values, Peak Flow, Water-Quality, and Unit Values files of WATSTORE are indexed in this file. It contains information pertinent to the identification, location, and physical description of nearly 220,000 sites.

Daily-Values File: All water-data parameters measured or observed either on a daily or on a continuous basis and numerically reduced to daily values are stored in this file. Instantaneous measurements at fixed-time intervals, daily mean values, and statistics such as daily maximum and minimum values also may be stored. This file currently contains over 200 million daily values including data on streamflow, river stages, reservoir contents, water temperatures, specific-conductance, sediment concentrations, sediment discharges, and ground-water levels.

Peak-Flow File: Annual maximum (peak) streamflow (discharge) and gage height (stage) values at surface-water sites comprise this file, which currently contains over 400,000 peak observations. 
Water-Quality File: Results of over 1.4 million analyses of water samples that describe the chemical, physical, biological, and radiochemical characteristics of both surface and ground waters are contained
in this file. These analyses contain data for 185 different constituents.

Unit Values File: Water parameters measured on a schedule more frequent than daily are stored in this data are examples of the types of data stored in the Unit Values File.

Ground-Water Site-Inventory File: This file is discussed above, but it is cross-referenced to the Water-Quality File and the Daily Values File. contains inventory data about wells, springs, and site location and identification geohydrologic characteristics, well-construction history, and onetime field measurements such as water temperature. The file is designed to accommodate 255 data elements and currently contains data for nearly 70,000 sites.

All data files of the WATSTORE system are maintained and managed on the central computer Center. However data may be entered into or retrieved from WATSTORE at a number of location that are part of a nationwide telecommunication network.

Remote Job-Entry Sites: Almost all of the Wate Resources Division's district offices are equipped with high-speed computer terminals for remote access to the watho to put data the system within several minutes to daciant, depending upon the priority placed on the request. The number of remote job entry sites is increased the need arises.

Digital-Transmission Sites: Digital recorders are used at many field locations to record values for parameters such as river stages, conductivity, wate temperature, turbidity, wind direction, and chlowhich is removed from the recorder and transmitted over telephone lines to the receiver at Reston, Virginia. The data are recorded on magnetic tape for use on the central computer. Extensive testing of satellite data collection platforms indicates their feasibility for collecting real-time hydrologic data on a national scale. Battery-operated radios are used as the communication link to the satellite. About 200 (1980).
Central-Laboratory System: The Water Resources Division's two water-quality laboratories,
located in Lakewood, Colorado, and Atlanta, Georgia, analyze more than 150,000 water samples per year. These laboratories are equipped to automatically perform chemical analyses ranging from determinations of simple inorganic compounds, such pesticides. As each analysis is completed, the results are verified by laboratory personnel and transmitted via a computer terminal to the central computer facilities to be stored in the Water-Quality File of WATSTORE.

Water data are used in many ways by decisionmakers for the management, development, and monitoring of our water resources. In addition to its WATSTORE can provide a variety of usef products ranging from simple data tables to complex statistical analyses. A minimal fee, plus the actua computer cost incurred in producing a desired product, is charged to the requester.

Computer-Printed Tables: Users most often request data from WATSTORE in the form of tables printed by the computer. These tables may contain the availability of data stored in the files. A variety of formats is available to display the many types of data.

Computer-Printed Graphs: Computer-printed graphs for the rapid analysis or display of data are another capability of WATSTORE. Computer programs are available to produce bar graph (histograry $X$, hine graphs, frequency distribution other similar items by means of line printers.

Statistical Analyses: WATSTORE interfaces with a proprietary statistical package (SAS) to provide extensive analyses of data such as regression analyses, the analysis of variance, transformations. and corretht

Digital Plotting: WATSTORE also makes use of software systems that prepare data for digital plotsoftware systems that prepare data for digital plocentral computer site. Plots that can be obtained include hydrographs, frequency distribution curves, $\mathrm{X}-\mathrm{Y}$ point plots, contour plots, and three-dimensional plots.

Data in Machine-Readable Form: Data stored in WATSTORE can be obtained in machine-readable to user-written computer programs. These data available in the standard storage format of the WAT-
STORE system or in the form of punched cards or card images on magnetic tape.

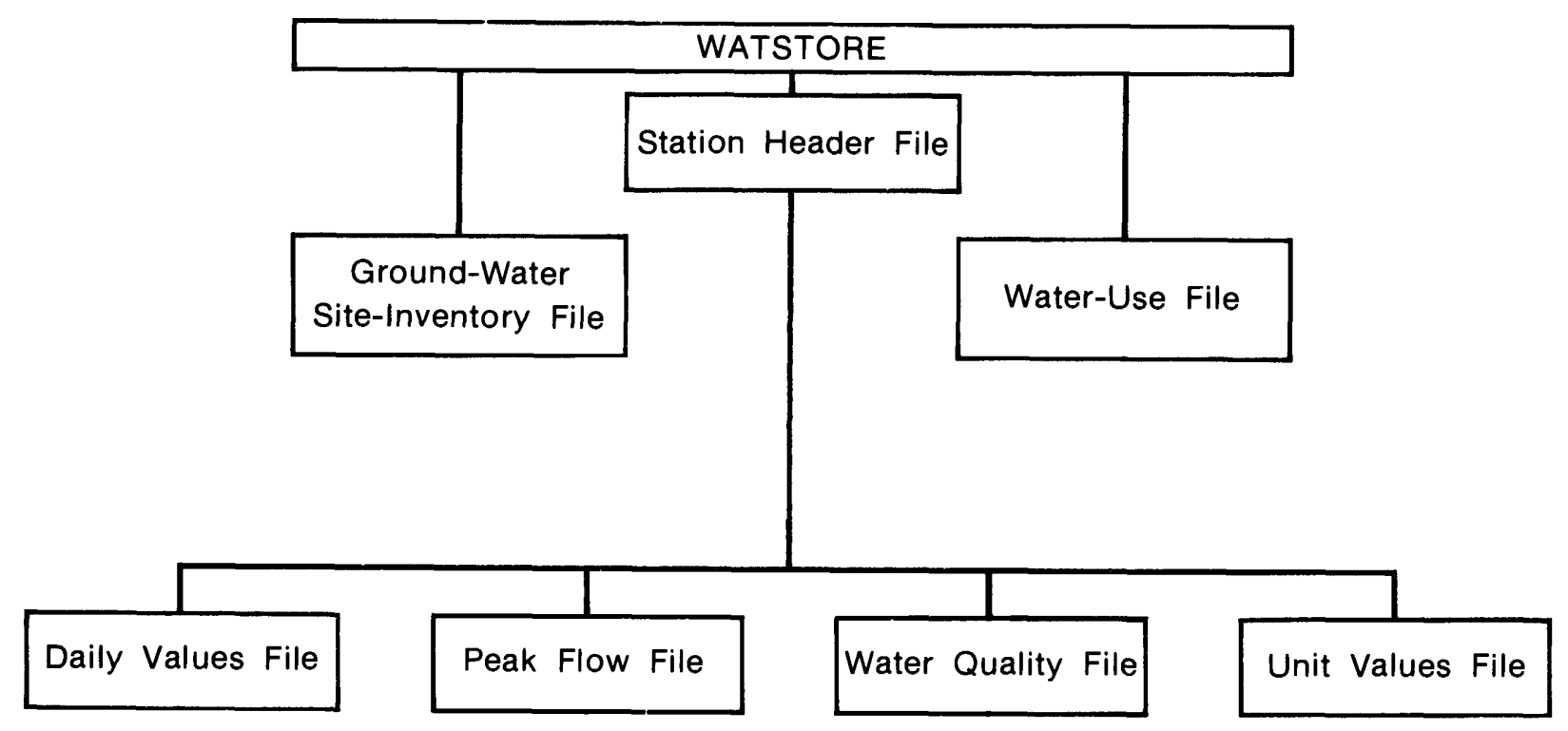

Figure 9.3-1 Index file stored data. 


\section{Water Data Indexed for Coal Provinces}

A special index "Index to Water-Data Activities in Coal Provinces of the United States" has been published by the U.S. Geological Survey's

Office of Water Data Coordination (OWDC).

The "Index to Water-Data Activities in Coal Provinces of the United Staces" was prepared to assist those involved in developing, managing, an regulating the Nation's coal resources by providing data in the major coal provinces of the United States. The index is derived from the "Catalog of Information on Water Data," which is a computerized information file about water-data acquisition activities in the United States and its territories and possessions, with some international activities included.

This special index consists of five volumes (fig. 9.4-1): volume I, Eastern Coal province; volume II Plains and Rocky Mountain Coal provinces; volume IV, Gulf Coast Coal province; and volume V, Pacific Coast and Alaska Coal provinces. The information presented will aid the user in obtaining data for evaluating the effects of coal mining on water resources and in developing plans for meeting additional water data needs. The report does not contain the actual data, rather, il provides inform not conthat will enable the

Each volume of this special index consists of four parts: Part A, Streamflow B, Quality of Surface-Water Stations; Part C, Quality of Ground-Water Stations; and Part D, Area Investigations and Miscellaneous Activities. Information given for each activity in Parts A-C includes
(1) the identification and location of the station, (2) the major types of data collected, (3) the frequency of data collection, (4) the form in which the data are (t) the activity. Part D summarizes hydrologic investither parts of the index. The asencies that submitted the information, agency codes, and the number of activities reported by type are included.

Those who need additional information from the Catalog File or who need assistance in obtaining water data should contact the National Water Data (See section 9.2.)

Further information on the index volumes and their availability may be obtained from:

U.S. Geological Survey Water Resources Division

MS 415 Box 25046 Denver Federal Center Lakewood, CO 80225

District Chief U.S. Geological Survey Water Resources Division 505 Marquette NW, Room 720 Western Bank Building
Albuquerque, NM 87102 


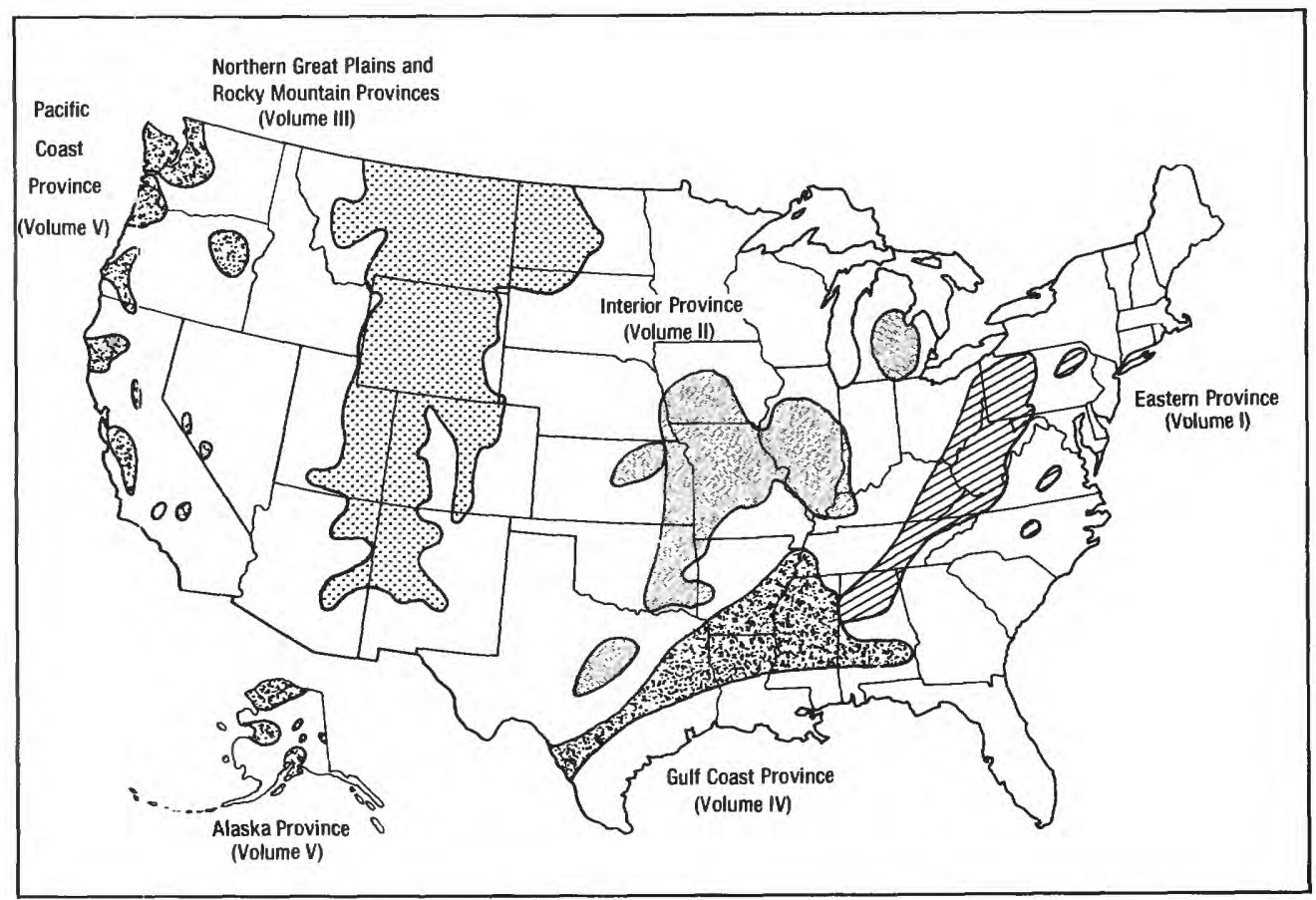

Figure 9.4-1 Index volumes and related provinces. 


\subsection{WATER-DATA SOURCES--Continued \\ 9.5 Availability of Topographic Maps}

\section{All of Area 61 Has Been Mapped}

\section{Most of the area is mapped at a scale of 1:24,000 with parts of western Colfax County, New Mexico, mapped at a scale of 1:62,500.}

Topographic maps are being made by the U.S. Geological Survey to cover the United States and territories. Quadrangles covering 7.5 minutes of latitude and longitude are published at the scale of $1: 24,000$ ( 1 inch $=2,000$ feet). Quadrangles covering 15 minutes of latitude and longitude are published at the scale of 1:62,500 ( 1 inch = approximately 1 mile). U.S. Geological Survey quadrangies covering $1^{\circ}$ of latitude and $2^{\circ}$ of longitude are published at the scale of 1:250,000 ( 1 inch $=$ about 4 miles).

Topographic maps prepared in the county format from U.S. Geological Survey quadrangles also are available. The scale of these maps is either $1: 50,000$ or $1: 100,000$. Large counties are printed on two or more sheets.

Topographic mapping of Area 61 is complete and represented by 7.5 -and 15 -minute quadrangles (fig. 9.5-1). Area 61 also is available on two quadrangles of the United States series scale 1:250,000 maps. These are the Trinidad and the Raton quadrangles which are shown in figure 9.5-2. County maps are available for Huerfano and Las Animas Counties, Colo. (fig. 9.5-3).

Many libraries maintain reference files of the maps published by the U.S. Geological Survey and many of the maps are stocked and sold over the counter by dealers in private business. A list of the libraries and dealers stocking maps can be obtained from:

\author{
Western Distribution Branch \\ U.S. Geological Survey \\ Box 25425 \\ Federal Center \\ Denver, CO 80225
}

Maps also may be purchased over the counter or by mail from this branch.

Aerial and space imagery including photographs, satellite computer compatible tapes, photoindexes, and other remote sensor data is also available for the area. For additional information or assistance in ordering these items, contact one of the following offices:

\section{U.S. Geological Survey EROS Data Center Sioux Falls, SD 57198}

or

U.S. Geological Survey Rocky Mountain Mapping Center National Cartographic Information Center Mail Stop 504, Denver Federal Center Denver, CO 80225 

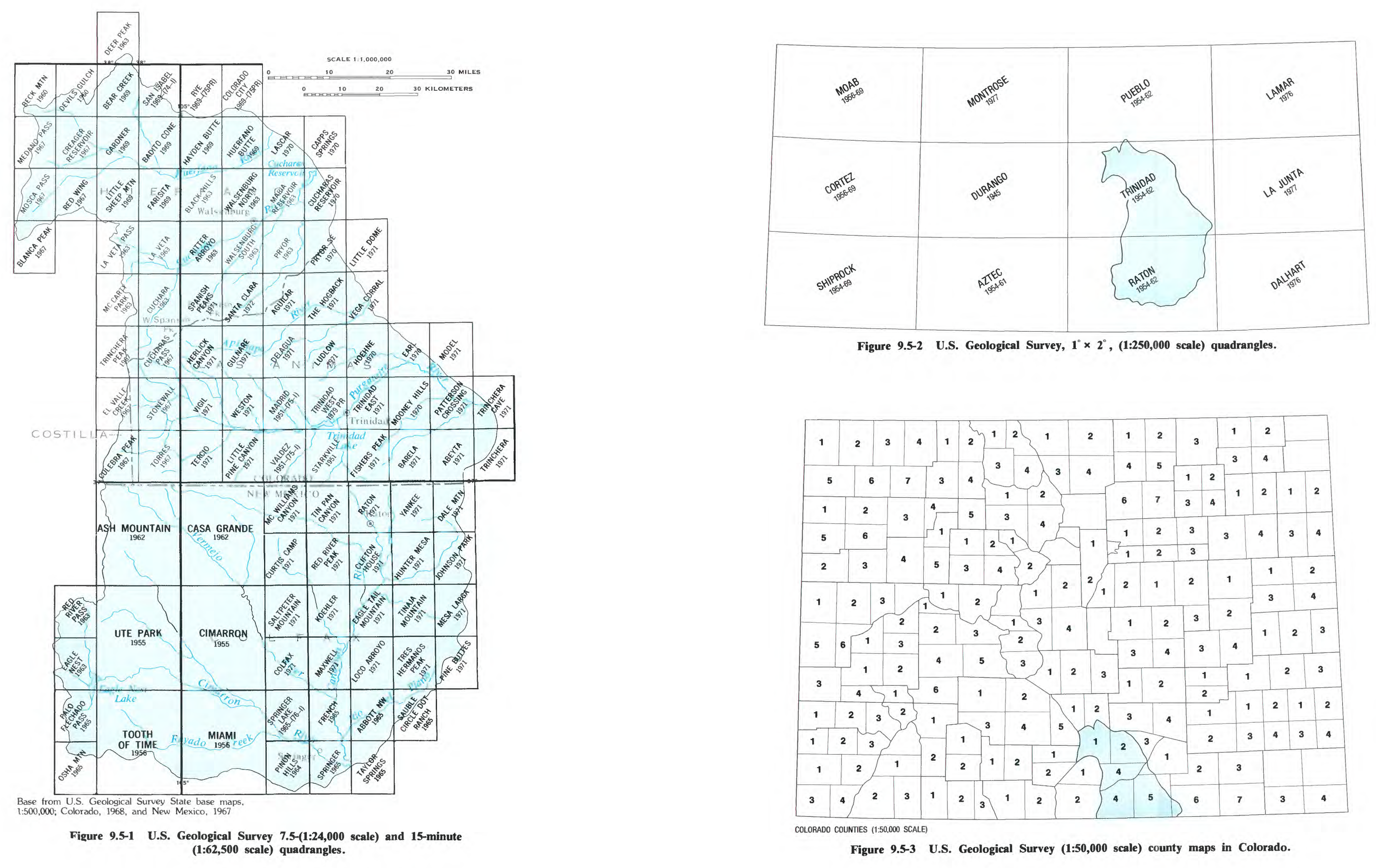
10.0 SUPPLEMENTAL INFORMATION FOR AREA 61

10.1 Surface-Water Stations

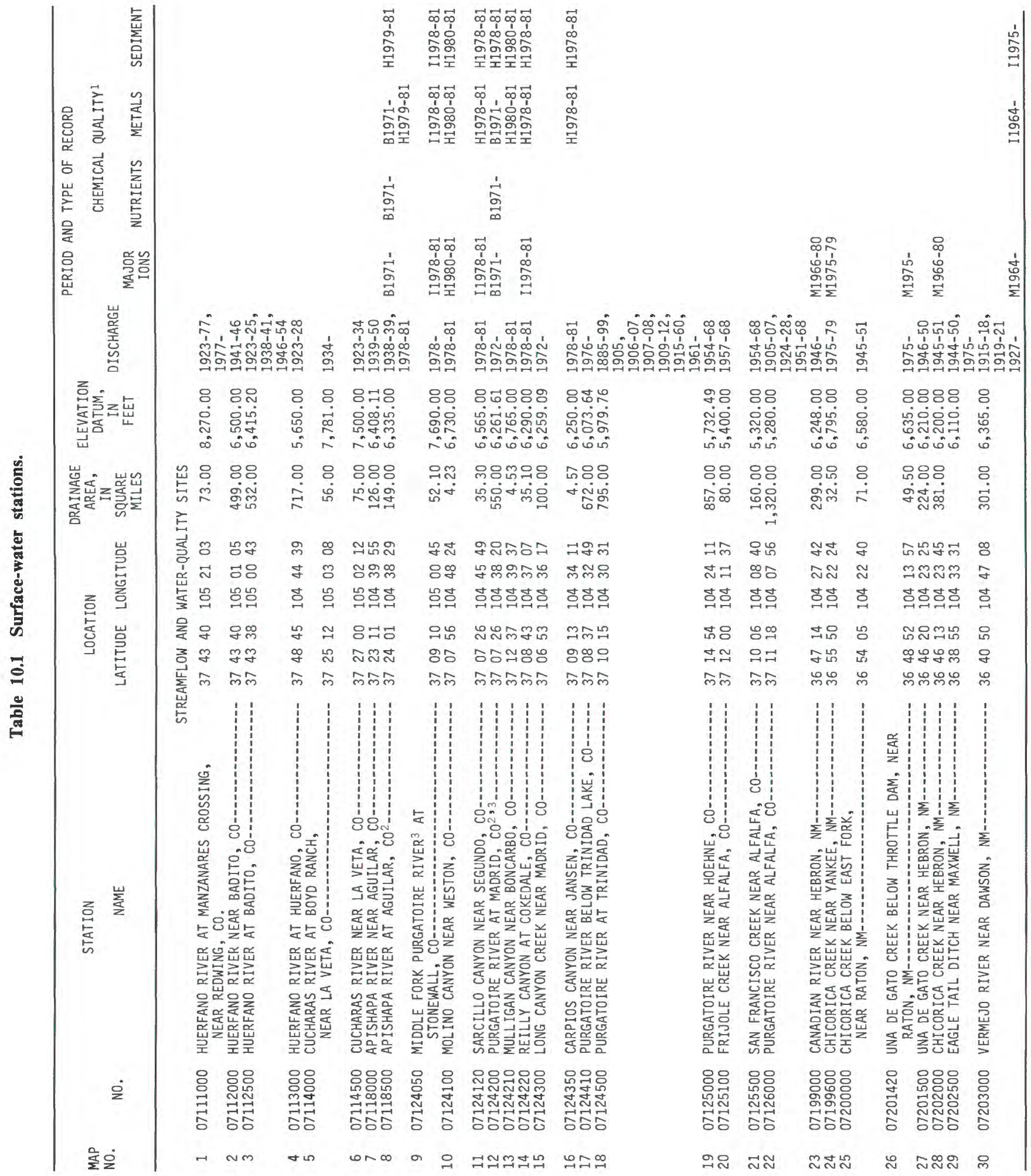



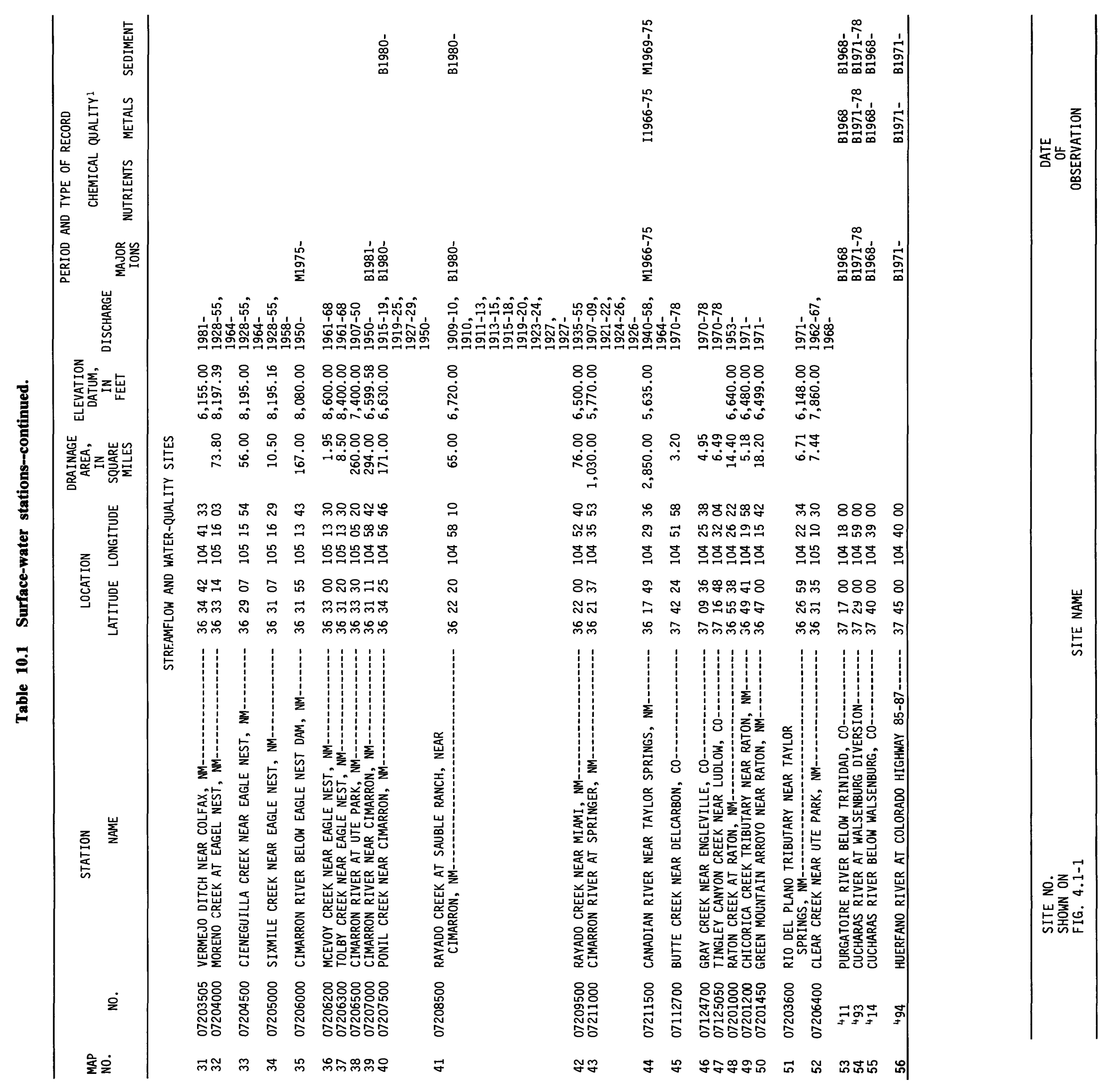

$\stackrel{20}{g}$

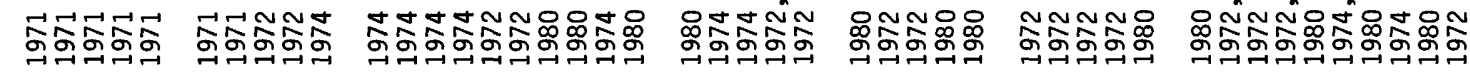

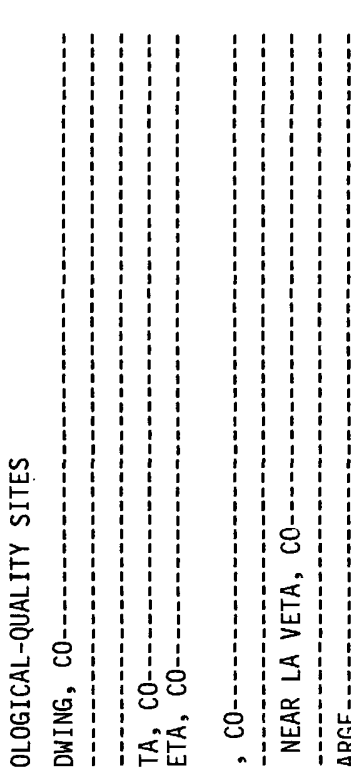

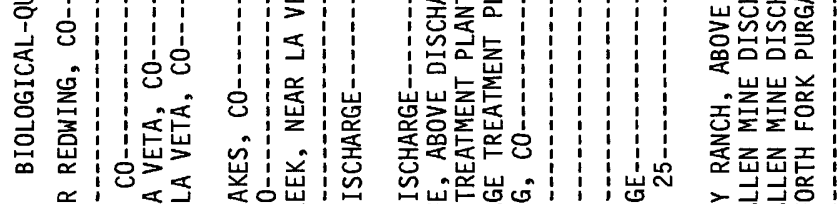

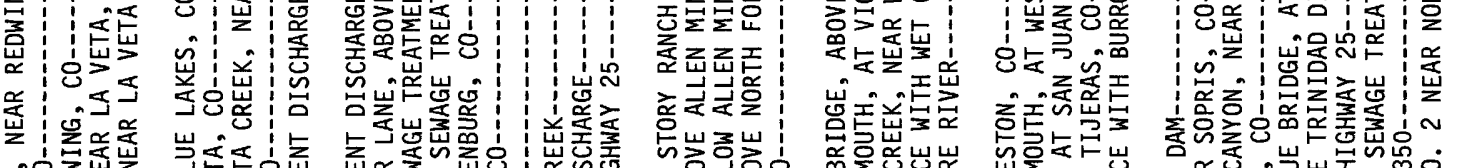

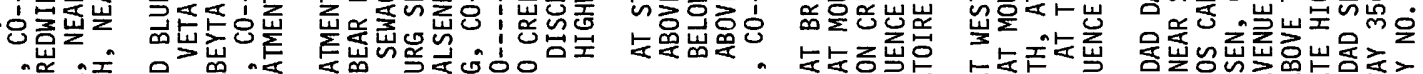

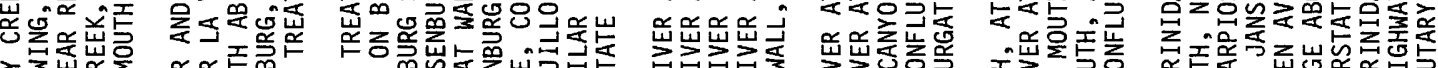

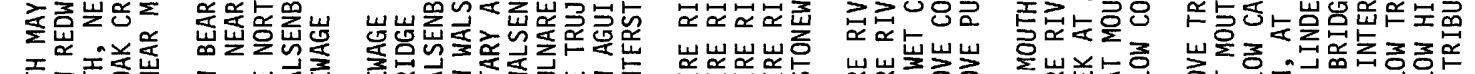

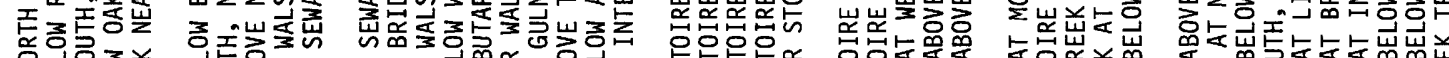

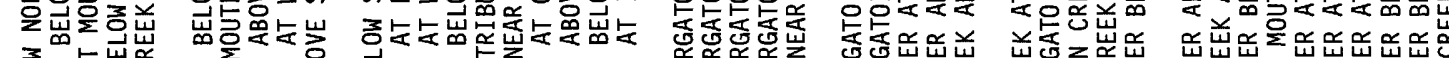

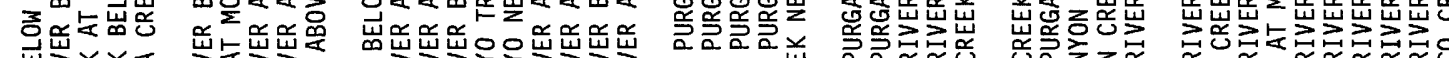

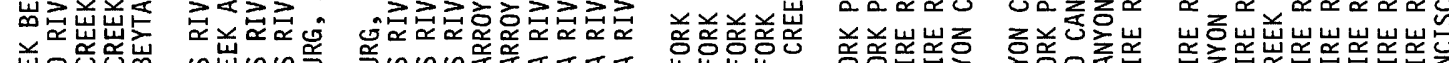

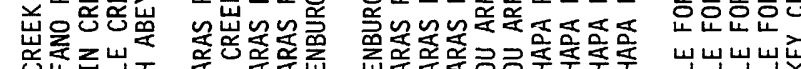

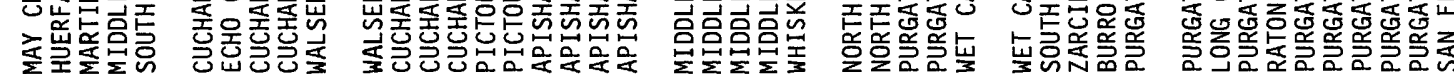

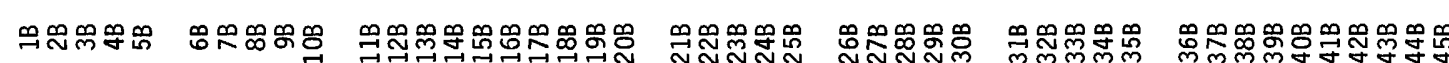


10.0 SUPPLEMENTAL INFORMATION FOR AREA 61--Continued

10.2 Ground-Water Stations

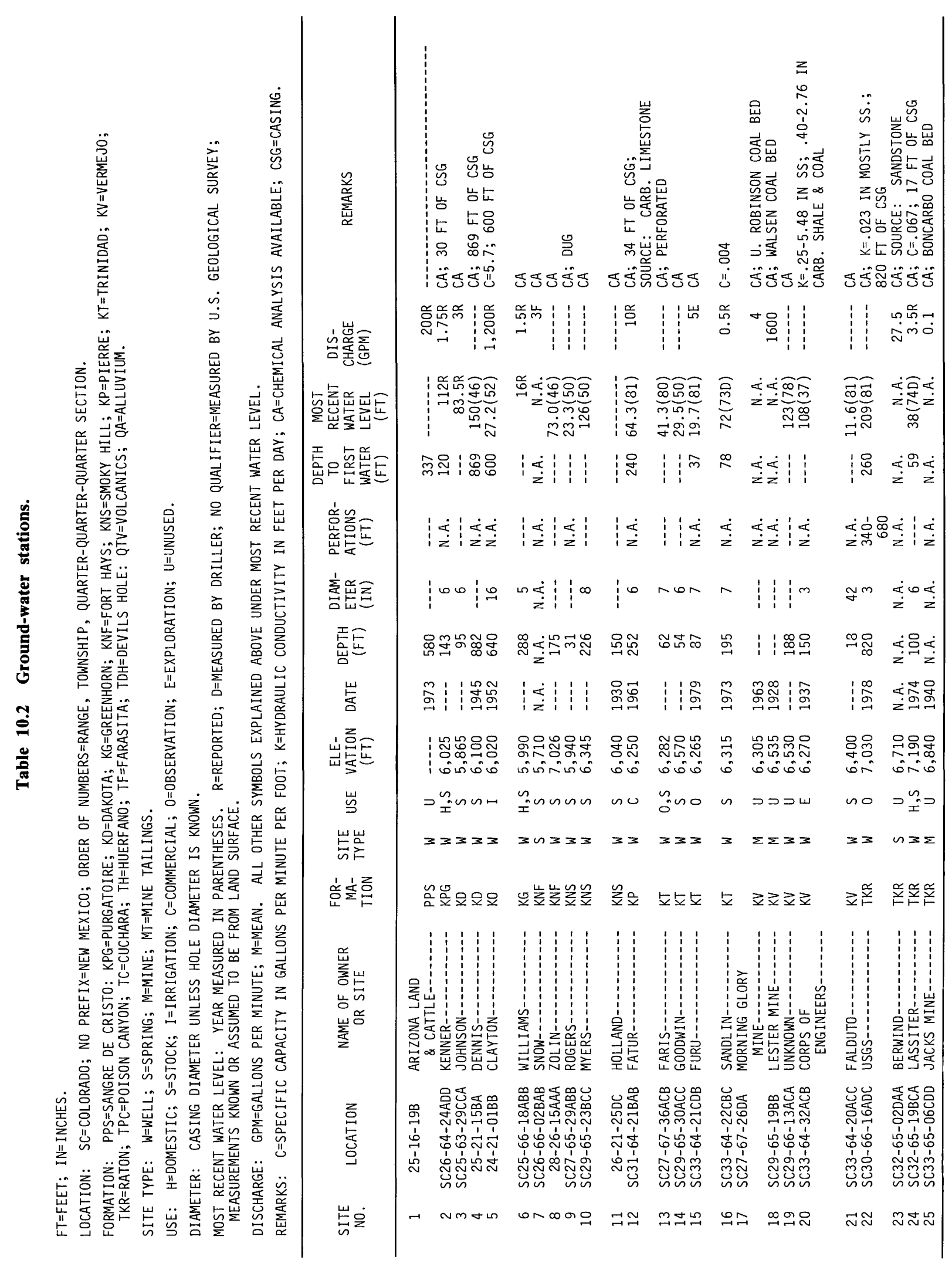




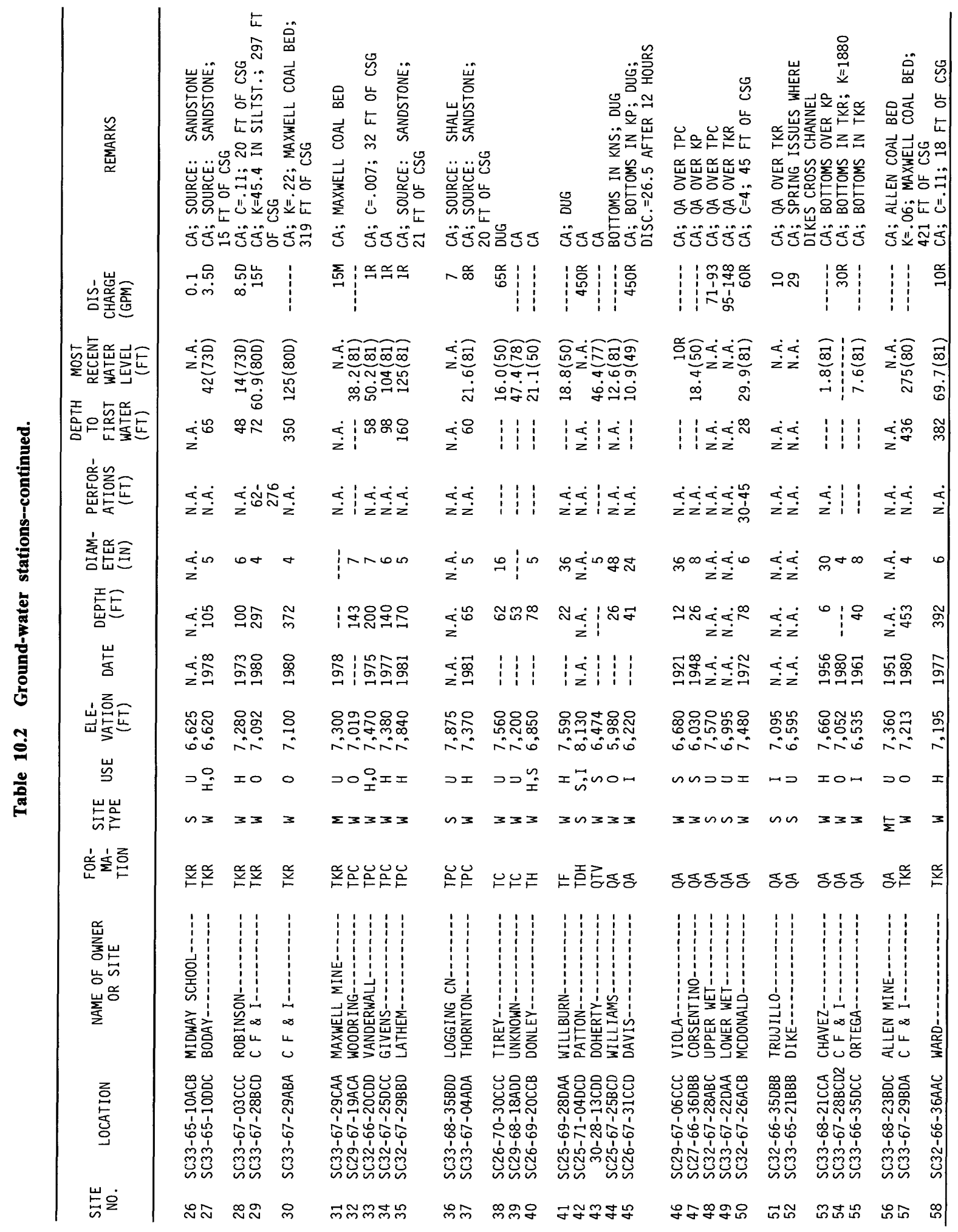




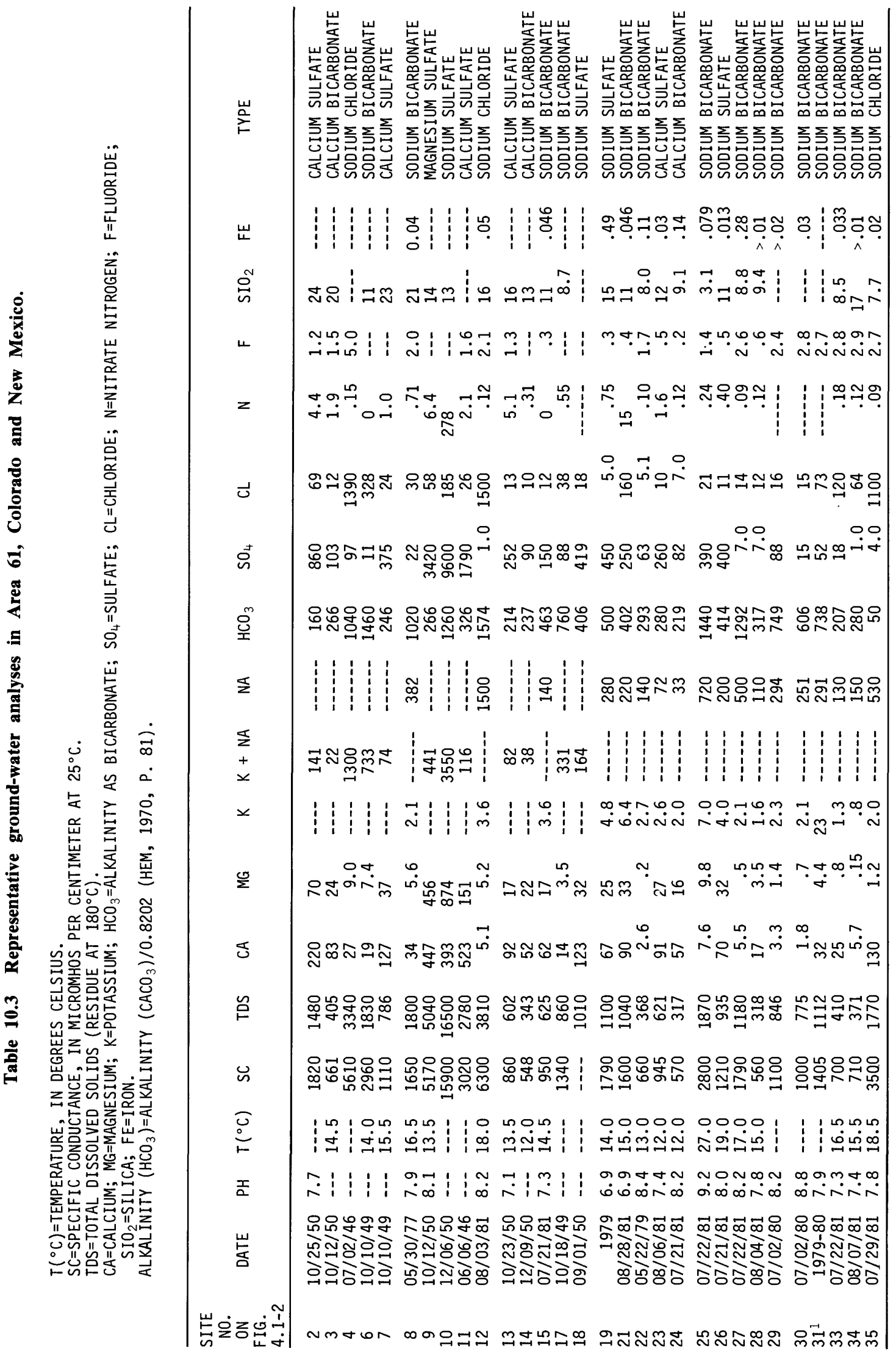




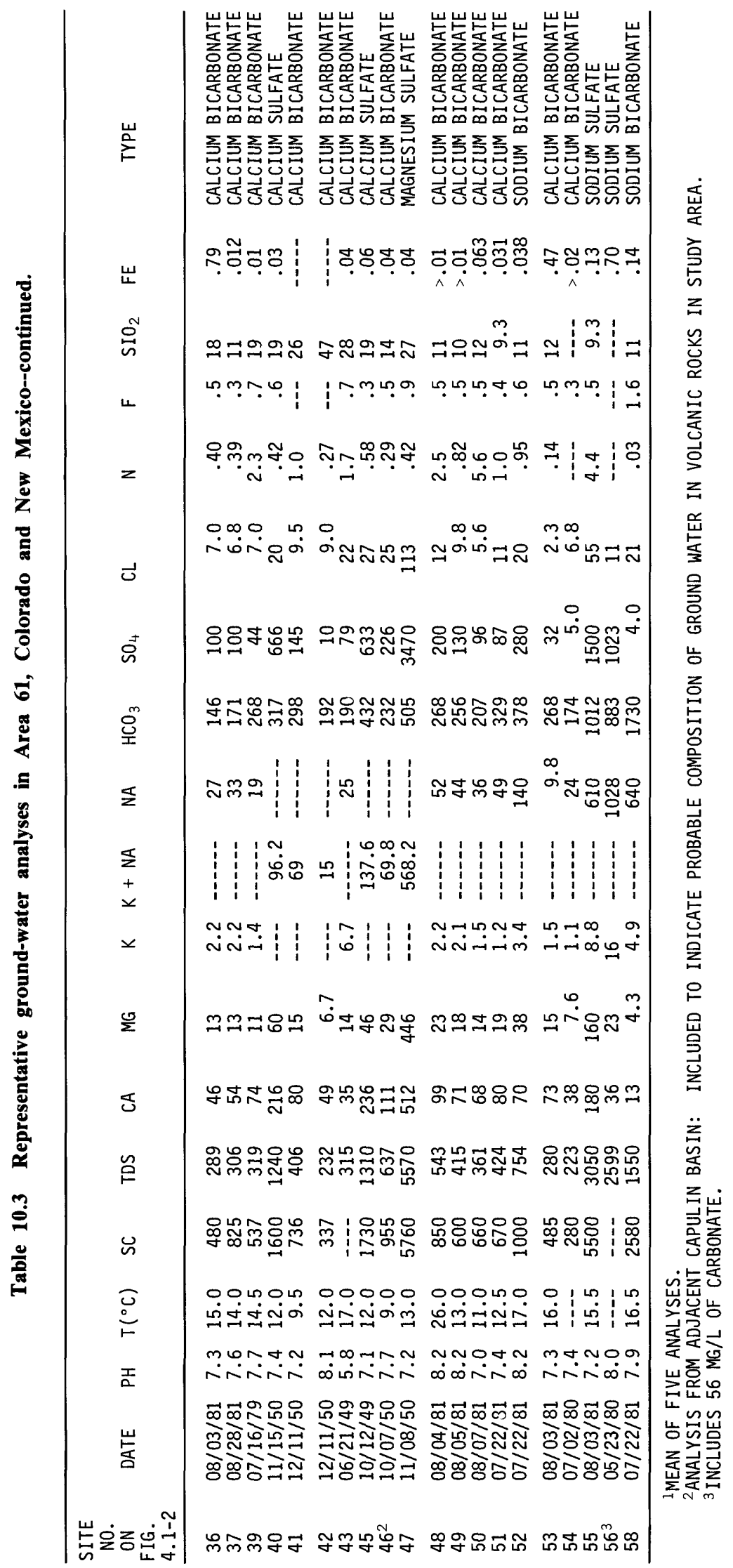




\subsection{TOPICAL LIST OF SELECTED REFERENCES}

\section{Land}

Brady, N. C., 1974, The nature and properties of soils (8th ed.): New York, Macmillan Publishing Co., Inc., $639 \mathrm{p}$.

Colorado Land Use Commission, 1974, A land use program for Colorado: Denver, Colo., 247 p., plus 12-map folio.

Fenneman, N. M., 1931, Physiography of western United States: New York, McGraw-Hill Book Co., Inc., 534 p.

Heil, R. D., Romine, D. S., Moreland, D. C., Dansdill, R. K., Montgomery, R. H., and $\mathrm{Cu}-$ pra, J. E., 1977, Soils of Colorado [Prepared in cooperation with the U.S. Soil Conservation Service]: Fort Collins, Colorado State University Experiment Station Bulletin 566S, 39 p., map.

New Mexico Interstate Stream Commission and the New Mexico State Engineers Office, 1968a, New Mexico State Water Plan land-use map, scale 1 inch $=10$ miles [See reference U.S. Bureau of Reclamation, 1976, map no. 2].

1968b, New Mexico State Water Plan land ownership and administration map, scale 1 inch $=10$ miles [Reference U.S. Bureau of Reclamation, 1976, map no. 1].

Pettit, R. F., 1966, Maxwell Land Grant, in New Mexico Geological Society Annual Field Conference Guidebook No. 17 (Guidebook of TaosRaton-Spanish Peaks country, New Mexico and Colorado): p. 66-68.

U.S. Bureau of Reclamation, 1976, New Mexico water resources assessment for planning purposes [Prepared in cooperation with the State of New Mexico]: Denver, Colo., 218 p., folio of 23 maps.

U.S. Geological Survey, 1980, Map, land use and land cover, 1974-79, Trinidad, Colorado: U.S. Geological Survey Open-File Report 80-263-1, Land Use Series, scale 1:250,000.

U.S. Soil Conservation Service, 1974, General soils map of New Mexico [Prepared in cooperation with the New Mexico State University Agricultural Experiment Station]: Albuquerque, N. Mex., scale 1:1,000,000.

1976, Maps, land use and natural plant communities, Huerfano County, Colorado, and Las Animas County, Colorado: Denver, Colo., with accompanying type descriptions.

\section{Geology}

Amuedo and Ivey, 1974, Regional coal resources study of the Trinidad-Raton basin, Colorado and New Mexico: Denver, Colo., Amuedo and Ivey Engineering Consultants, unpublished report, $1 \mathrm{v}$.

Billingsley, L. T., 1977, Stratigraphy of the Trinidad Sandstone and associated formations, Walsenburg area, Colorado, in Exploration Frontiers of the Central and Southern Rockies: Rocky Mountain Association of Geologists Annual Field Conference Guidebook, p. 235-246.

Bolyard, D. W., 1956, Permo-Pennsylvanian section at La Veta Pass, Colorado, in Guidebook to the Geology of the Raton Basin, Colorado: Rocky Mountain Association of Geologists, p. 52-55.

Clair, J. R., and Bradish, B. B., 1956, Garcia gas field, Las Animas County, Colorado, in Guidebook to the Geology of the Raton Basin, Colorado: Rocky Mountain Association of Geologists, p. 76-78.

Cobban, W. A., 1956, The Pierre Shale and older Cretaceous rocks in south-eastern Colorado, in Guidebook to the Geology of the Raton Basin, Colorado: Rocky Mountain Association of Geologists, p. 25-27.

Creely, R. S., and Saterdal, A. O., 1956, BaditoAlamo area, Huerfano County, Colorado, in Guidebook to the Geology of the Raton Basin, Colorado: Rocky Mountain Association of Geologists, p. 71-74.

Dane, C. H., and Bachman, G. O., 1965, Geologic map of New Mexico [Prepared with the cooperation of the New Mexico Institute of Mining and Technology, State Bureau of Mines and Minerals Resources Division, and the University of New Mexico Department of Geology]: U.S. Geological Survey map, scale 1:500,000; sheet 1, geologic map; sheet 2, explanation.

Danilchik, Walter, 1978, Preliminary results of 1978 coal exploratory drilling in the Trinidad-Raton coal region, Las Animas County, Colorado: U.S. Geological Survey Open-File Report 78-1101, 19 p., 1 pl., 3 logs.

1979a, Geologic and coal outcrop map of the Madrid quadrangle, Las Animas County, Colorado: U.S. Geological Survey Open-File Report 79-377, 1 pl., scale 1:24,000.

$1979 \mathrm{~b}$, Geologic and coal outcrop map of the Weston quadrangle, Las Animas County, Colorado: U.S. Geological Survey Open-File Report 79-927, 1 over-size sheet, scale 1:24,000.

Dolly, E. D., and Meissner, F. F., 1977, Geology and gas exploration potential, Upper Cretaceous and lower Tertiary strata, northern Raton Basin, Colorado, in Veal, H. K., ed., Exploration fron- 
tiers of the central and southern Rockies: Rocky Mountain Association of Geologists Field Conference Guide-book, p. 247-270.

Fassett, J. E., 1976, What happened during late Cretaceous time in the Raton and San Juan basins; with some thoughts about the area in between, in Ewing, R. C., and Kues, B. S., eds., New Mexico Geological Society Annual Field Conference Guidebook No. 27 (Guidebook of Vermejo Park, north eastern New Mexico): p. 185-190.

Gabelman, J. W., 1956, Tectonic history of the Raton Basin region, in Guidebook to the Geology of the Raton Basin, Colorado: Rocky Mountain Association of Geologists, p. 35-39.

Griggs, R. L., 1948, Geology and ground-water resources of the eastern part of Colfax County, New Mexico: New Mexico Bureau of Mines and Mineral Resources Ground Water Report 1187 p.

Griggs, R. L., and Northrop, S. A., 1956, Stratigraphy of the Plains area adjacent to the Sangre de Cristo Mountains, New Mexico, in New Mexico Geological Society Annual Field Conference Guidebook No. 7 (Guidebook of Southeastern Sangre de Cristo Mountains, New Mexico): p. 134-138.

Harbour, R. L., and Dixon, G. H., 1956, Geology of the Trinidad-Aguilar areas, Las Animas and Huerfano Counties, Colorado: U.S. Geological Survey Oil and Gas Investigations Map OM-174, scale 1:31,680.

1959, Coal resources of Trinidad-Aguilar area, Las Animas and Huerfano Counties, Colorado: U.S. Geological Survey Bulletin 1072-G, p. iv, 445-489.

Johnson, R. B., 1958, Geology and coal resources of the Walsenburg area, Huerfano County, Colorado: U.S. Geological Survey Bulletin 1042-O, p. 557-583.

1959, Geology of the Huerfano Park area, Huerfano and Custer Counties, Colorado: U.S. Geological Survey Bulletin 1071-D, p. iii, 87-119. 1968 , Geology of the igneous rocks of the Spanish Peaks region, Colorado: U.S. Geological Survey Professional Paper 594-G, p. G1-G47.

1969, Geologic map of the Trinidad quadrangle, south-central Colorado: U.S. Geological Survey Miscellaneous Geologic Investigations Map I-558, scale 1:125,000.

Johnson, R. B., Dixon, G. H., and Wanek, A. A., 1956, Late Cretaceous and Tertiary stratigraphy of the Raton Basin of New Mexico and Colorado, in New Mexico Geological Society Annual Field Conference Guidebook No. 7 (Guidebook of Southeastern Sangre de Cristo Mountains, New Mexico): p. 122-133.

Johnson, R. B., and Stephens, J. G., 1951, Geology of the La Veta area, Huerfano County, Colora- do: U.S. Geological Survey Oil and Gas Investigations Map OM-146, scale 1:31,680.

Johnson, R. B., and Wood, G. H., Jr., 1956, Stratigraphy of upper Cretaceous and Tertiary rocks of Raton Basin, Colorado and New Mexico, in Guidebook of the Raton Basin, Colorado: Rocky Mountain Association of Geologists, p. 28-34.

Johnson, R. B., Wood, G. H., Jr., and Harbour, R. L., 1958, Preliminary geologic map of the northern part of the Raton Mesa region and Huerfano Park in parts of Las Animas, Huerfano, and Custer Counties, Colorado: U.S. Geological Survey Oil and Gas Investigations Map OM-183, scale 1:63,360, 2 sheets.

Knopf, Adolph, 1956, Igneous geology of the Spanish Peaks region, Colorado, in Guidebook to the Geology of the Raton Basin, Colorado: Rocky Mountain Association of Geologists, p. 56-57.

Lee, W. T., 1924, Coal resources of the Raton coal field, Colfax County, New Mexico: U.S. Geological Survey Bulletin 752, $254 \mathrm{p}$.

Lee, W. T., and Knowlton, F. H., 1917, Geology and paleontology of the Raton Mesa and other regions; Colorado and New Mexico: U.S. Geological Survey Professional Paper 101, 450 p.

McLaughlin, T. G., 1966, Ground water in Huerfano County, Colorado. U.S. Geological Survey Water-Supply Paper 1805, $91 \mathrm{p}$.

Oriel, S. S., and Mudge, M. R., 1956, Problems of lower Mesozoic stratigraphy in southeastern Colorado, in Guidebook to the Geology of the Raton Basin, Colorado: Rocky Mountain Association of Geologists, p. 19-24.

Pillmore, C. L., 1964, Geologic map of the Catskill SW quadrangle, Colfax County, New Mexico: U.S. Geological Survey Open-File Report 123, scale $1: 24,000,1$ sheet.

1965a, Geologic map of the Catskill SE quadrangle, Colfax County, New Mexico: U.S. Geological Survey Open-File Report 121, scale $1: 24,000,1$ sheet.

1965b, Geologic map of the Catskill NE quadrangle, Colfax County, New Mexico: U.S. Geological Survey Open-File Report 122, scale $1: 24,000,1$ sheet.

1966, Geologic map of the Catskill NW quadrangle, New Mexico and Colorado: U.S. Geological Survey Open-File Report 104, scale $1: 24,000,1$ sheet.

1969a [1970], Geologic map of the Casa Grande quadrangle, Colfax County, New Mexico, and Las Animas County, Colorado: U.S. Geological Survey Geologic Quadrangle Map GQ-823, scale 1:62,500.

$1969 \mathrm{~b}$, Geology and coal deposits of the Raton coal field, Colfax County, New Mexico: Mountain Geologist, v. 6, p. 125-142.

1976a, Second day road log from Raton to 
Underwood lakes through the Raton coal field via the York Canyon Mine, Vermejo Park, and Gold Creek, in Ewing, R. C., and Kues, B. S., eds., New Mexico Geological Society Annual Field Conference Guidebook No. 27 (Guidebook of Vermejo Park, northeastern New Mexico): p. 25-48.

1976b, Third day road log from Raton to Adams and Bartlett lakes, Vermejo Park, New Mexico, through Trinidad coal field and Tercio Anticline, Colorado; return via Van Bremer Canyon and Colfax, New Mexico, in Ewing, $\mathbf{R}$. C., and Kues, B. S., eds., New Mexico Geological Society Annual Field Conference Guidebook No. 27 (Guidebook of Vermejo Park, northeastern New Mexico): p. 49-69.

1976c, Commercial coal beds of the Raton coal field, Colfax County, New Mexico, in New Mexico Geological Society Annual Field Conference Guidebook No. 27 (Guidebook of Vermejo Park, northeastern New Mexico): p. 227-239.

Powell, W. J., 1952, Ground water in the vicinity of Trinidad, Colorado: Colorado Water Conservation Board Ground-Water Circular 3, 28 p.

Robinson, G. D., Wanek, A. A., Hays, W. H., and McCallum, M. E., 1964, Philmont country--the rocks and landscape of a famous New Mexico ranch: U.S. Geological Survey Professional $\mathrm{Pa}$ per 505, $152 \mathrm{p}$.

Shaw, G. L., 1956, Subsurface stratigraphy of the Permian-Pennsylvanian beds, Raton Basin, Colorado, in Guidebook to the Geology of the Raton Basin, Colorado: Rocky Mountain Association of Geologists, p. 14-18.

Speer, W. R., 1976, Oil and gas exploration in the Raton Basin, in Ewing, R. C., and Kues, B. S., eds., New Mexico Geological Society Annual Field Conference Guidebook No. 27 (Guidebook of Vermejo Park, northeastern New Mexico): p. 217-226.

Smith, R. P., 1979, Early rift magmatism at Spanish Peaks, Colorado, in Riecker, R. E., ed., Rio Grande Rift; tectonics and magmatism: American Geophysical Union, p. 313-321.

Tweto, Ogden, compiler, 1979 |19801, Geologic map of Colorado: U.S. Geological Survey map, scale 1:500,000, 1 sheet.

Vine, J. D., 1974, Geologic map and cross sections of the La Veta Pass, La Veta and Ritter Arroyo quadrangles, Huerfano and Costilla Counties, Colorado: U.S. Geological Survey Miscellaneous Geologic Investigations Map I-833, scale $1: 48,000$.

Wanek, A. A., 1963 [1964], Geology and fuel resources of the southwest of the Raton coal field, Colfax County, New Mexico: U.S. Geological Survey Coal Investigations Map C-45, scale $1: 48,000,2$ sheets.

Wood, G. H., Jr., Johnson, R. B., and Dixon, G.
H., 1956, Geology and coal resources of the Gulnare, Cuchara Pass, and Stonewall area, Huerfano and Las Animas Counties, Colorado: U.S. Geological Survey Coal Investigations Map C-26, scale 1:31,680, 2 sheets.

1957, Geology and coal resources of the Starkville-Weston area, Las Animas County, Colorado: U.S. Geological Survey Bulletin $1051,68 \mathrm{p}$.

Wood, G. H., Jr., Johnson, R. B., Eargle, D. H., Duggner, R. T., and Major, Harold, 1951, Geology and coal resources of the Stonewall-Tercio area, Las Animas County, Colorado: U.S. Geological Survey Coal Investigations Map C-4, scale $1: 31,680,2$ sheets.

\section{Coal}

Amuedo, C. L., and Bryson, R. S., 1977, TrinidadRaton basins--a model coal resource evaluation program, in Murray, D. K., ed., Geology of Rocky Mountain Coal Symposium, 1976, Proceedings: Colorado Geological Survey, Resource Series 1, p. 45-60.

Amuedo and Ivey, 1974, Regional coal resources study of the Trinidad-Raton basin, Colorado and New Mexico: Denver, Colo., Amuedo and Ivey Engineer ing Consultants, unpublished report, $1 \mathrm{v}$.

Berryhill, L. R., and Averitt, Paul, 1951, Cokingcoal deposits of the western United States: U.S. Geological Survey Circular 90, p. 14-15.

Boreck, D. L., and Murray, D. K., 1979, Colorado coal reserves depletion data and coal mine summaries: Colorado Geological Survey Open-File Report 79-1, 65 p.

Carter, D. A., 1956, Coal deposits of the Raton Basin, in Guidebook to the Geology of the Raton Basin, Colorado: Rocky Mountain Association of Geologists, p. 89-92.

Danilchik, Walter, 1979, Geologic and coal outcrop map of the Madrid quadrangle, Las Animas County, Colorado: U.S. Geological Survey Open-File Report 79-377, 1 sheet, scale 1:24,000.

Dawson, L. C., and Murray, D. K., compilers, 1978, Colorado coal directory and source book: Colorado Geological Survey Resources Series 3, $225 \mathrm{p}$.

Harbour, R. L., and Dixon, G. H., 1959, Coal resources of Trinidad-Aguilar area, Las Animas and Huerfano Counties, Colorado: U.S. Geological Survey Bulletin 1072-G, p. iv, 445-489.

Johnson, R. B., 1958, Geology and coal resources of the Walsenburg area, Huerfano County, Colorado: U.S. Geological Survey Bulletin 1042-O, p. 557-583.

1961, Coal resources of the Trinidad coal field in Huerfano and Las Animas Counties, Colorado, in Contributions to Economic Geolo- 
gy: U.S. Geological Survey Bulletin 1112-E, p. 129-180.

Johnson, R. B., and Stephens, J. G., 1954, Coal resources of the La Veta area, Huerfano County, Colorado: U.S. Geological Survey Coal Investigations Map C-20, scale 1:31,360.

Lee, W. T., 1924, Coal resources of the Raton coal field, Colfax County, New Mexico: U.S. Geological Survey Bulletin 752, $254 \mathrm{p}$.

Lee, W. T., and Knowlton, F. H., 1917, Geology and paleontology of the Raton Mesa and other regions; Colorado and New Mexico: U.S. Geological Survey Professional Paper 101, 450 p.

McLaughlin, T. G., 1966, Ground water in Huerfano County, Colorado: U.S. Geological Survey Water-Supply Paper 1805, $91 \mathrm{p}$.

Nielsen, G. F., ed., 1979, 1979 Keystone coal industry manual: New York, McGraw-Hill Mining Publications. 1980, 1980 Keystone coal industry manual: New York, McGraw-Hill Mining Publications.

Pillmore, C. L., 1969a |19701, Geologic map of the Casa Grande quadrangle, Colfax County, New Mexico, and Las Animas County, Colorado: U.S. Geological Survey Geologic Quadrangle Map GQ-823, scale 1:62,500.

$1969 \mathrm{~b}$, Geology and coal deposits of the Raton coal field, Colfax County, New Mexico: Mountain Geologist, v. 6, p. 125-142.

1976, Commercial coal beds of the Raton coal field, Colfax County, New Mexico, in Ewing, R. C., and Kues, B. S., eds., New Mexico Geological Society Annual Field Conference Guidebook No. 27 (Guidebook of Vermejo Park, northeastern New Mexico): p. 227-239.

Richardson, G. B., 1910, The Trinidad coal field, Colorado: U.S. Geological Survey Bulletin 381, p. 379-446.

Speltz, C. N., 1976, Strippable coal resources of Colorado: U.S. Bureau of Mines Information Circular 8713, $70 \mathrm{p}$.

Wanek, A. A., 1963 |19641, Geology and fuel resources of the southwestern part of the Raton coal field, Colfax County, New Mexico: U.S. Geological Survey Coal Investigations Map C45 , scale $1: 48,000,2$ sheets.

Water, Waste, and Land, Ltd., 1980, Hydrology, geology, and water quality in vicinity of the Maxwell and Allen Mines, Las Animas County, Colorado: Final report to CF\&I Steel Corp. by Water, Waste, and Land, Ltd., Consultants to Mining, Agriculture, and Government, Fort Collins, Colo.

Wood, G. H., Jr., Johnson, R. B., and Dixon, G. H., 1956, Geology and coal resources of the Gulnare, Cuchara Pass, and Stonewall area, Huerfano and Las Animas Counties, Colorado: U.S. Geological Survey Coal Investigations Map C-26, scale 1:31,680, 2 sheets.
1957, Geology and coal resources of the Starkville-Weston area, Las Animas County, Colorado: U.S. Geological Survey Bulletin $1051,68 \mathrm{p}$.

Wood, G. H., Jr., Johnson, R. B., Eargle, D. H., Duggner, R. T., and Major, Harold, 1951, Geology and coal resources of the StonewallTercio area, Las Animas County, Colorado: U.S. Geological Survey Coal Investigations Map C-4, scale $1: 31,680,2$ sheets.

\section{Climate}

National Oceanic and Atmospheric Administration, 1980, Climatological data annual summary Colorado 1980: Asheville, N.C., National Climatic Center, v. 85, no. 13.

U.S. Weather Bureau, 1959a, Climatography of the United States, Colorado, No. 60-5: $16 \mathrm{p}$. $1959 \mathrm{~b}$, Climatography of the United States, New Mexico, No. 60-29: 16 p. $1967 \mathrm{a}$, Normal annual precipitation, normal May-September precipitation, 1931-1960, Colorado: Map, scale 1:500,000.

$1967 \mathrm{~b}$, Normal annual precipitation, normal May-September precipitation, 1931-1960, New Mexico: Map, scale 1:500,000.

Washicheck, J. N., Shafer, B. A., and Teilborg, J. R., 1978, Summary of snow survey measurements for Colorado and New Mexico, 1971-1977: Denver, Colo., U.S. Soil Conservation Service, Snow Survey Unit, 128 p.

\section{Surface Water}

Borland, J. P., 1970, A proposed streamflow-data program for New Mexico: U.S. Geological Survey Open-File Report 35, $71 \mathrm{p}$.

Livingston, R. K., 1971, Evaluation of streamflowdata program in Colorado: U.S. Geological Survey Open-File Report 182, 76 p.

Livingston, R. K., Klein, J. M., and Bingham, D. L., 1976, Water resources of El Paso County, Colorado; a report prepared for Colorado Water Conservation Board: Colorado Water-Resources Circular 32, 85 p.

New Mexico Interstate Stream Commission and the New Mexico State Engineers Office, 1975, County profile Colfax County, New Mexico, water resource assessment for planning purposes: Santa Fe, N. Mex., 30 p., appendix.

Radosevich, G. E., Nobe, K. C., Allardice, D., and Kirkwood, C., 1976, Evolution and administration of Colorado Water Law: Fort Collins, Colo., Water Resources Publication, $280 \mathrm{p}$.

Sorensen, E. F., 1982, Water use by categories in New Mexico counties and river basins, and irrigated and dry cropland acreage in 1980 [Prepared in cooperation with U.S. Geological 
Survey]: Santa Fe, New Mexico State Engineer Technical Report 44, 50 p.

U.S. Weather Bureau, 1967c, Normal October-April precipitation, 1931-1960, Colorado: Map, scale $1: 500,000$.

1967d, Normal October-April precipitation, 1931-1960, New Mexico: Map, scale $1: 500,000$.

\section{Floods}

Federal Emergency Management Agency, 1981, National flood insurance program community status book (July 31, 1981, ed.): Washington, D.C., Federal Insurance Administration, 342 p.

Livingston, R. K., 1981, Rainfall-runoff modeling and preliminary regional flood characteristics of small rural watersheds in the Arkansas River basin in Colorado: U.S. Geological Survey Water-Resources Investigations $80-112,48$ p; available from U.S. Department of Commerce, National Technical Information Service, Springfield, VA 22161, as report PB81-224 313.

McCain, J. F., and Jarrett, R. D., 1976, Manual for estimating flood characteristics of natural-flow streams in Colorado: Colorado Water Conservation Board Technical Manual No. 1, $68 \mathrm{p}$.

Snipes, R. J., and others, 1974, Floods of June 1965 in Arkansas River basin, Colorado, Kansas, and New Mexico: U.S. Geological Survey WaterSupply Paper $1850-\mathrm{D}, 97 \mathrm{p}$.

Thomas, R. P., and Gold, R. L., 1982, Techniques for estimating flood discharges for unregulated streams in New Mexico: U.S. Geological Survey Water-Resources Investigations 82-24, $39 \mathrm{p}$.

U.S. Army Corps of Engineers, 1974, Flood plain information, Purgatoire River and tributaries, vicinity of Trinidad, Colorado: Albuquerque District, $57 \mathrm{p} ., 45 \mathrm{pl}$.

$1977 \mathrm{a}$, Flood plain information, Cucharas River and tributaries, La Veta, Colorado: Albuquerque District, 25 p., $22 \mathrm{pl}$.

$1977 \mathrm{~b}$, Flood plain information, Cucharas River and tributaries, Walsenburg, Colorado: Albuquerque District, 24 p., $18 \mathrm{pl}$.

Vaudrey, W. C., 1960, Floods of May 1955 in Colorado and New Mexico: U.S. Geological Survey Water-Supply Paper 1455-A, p. A1-A68.

\section{Ground Water}

Dames and Moore, 1978, Surface and ground water monitoring programs for Kaiser Steel Corp., York Canyon Mine, Raton, New Mexico: Report for Kaiser Steel Corp. by Dames and Moore Engineering Consultants, Denver, Colo.

Dinwiddie, G. A., 1964, Municipal water supplies and uses, northeastern New Mexico: New Mexico State Engineer Technical Report 29B, 64 p.
Freeze, R. A., and Cherry, J. A., 1979, Groundwater: Englewood Cliffs, N.J., Prentice-Hall, Inc., $604 \mathrm{p}$.

Griggs, R. L., 1948, Geology and ground-water resources of the eastern part of Colfax County, New Mexico: New Mexico Bureau of Mines and Mineral Resources, Ground-Water Report 1, 87 p.

Hart, D. L., Jr., and Smith, Christian, 1979, Ground water in the vicinity of Capulin, New Mexico: U.S. Geological Survey Water-Resources Investigations 79-79, 58 p.; available from U.S. Department of Commerce, National Technical Information Service, Springfield, VA 22161, as report PB300-827.

Hem, J. D., 1970, Study and interpretation of the chemical characteristics of natural water: U.S. Geological Survey Water-Supply Paper 1473, $363 \mathrm{p}$.

Howard, W. B., 1982, The hydrogeology of the Raton Basin, south-central Colorado: Indiana University, unpublished M.A. thesis, 95 p., appendices A-K.

McLaughlin, T. G., 1966, Ground water in Huerfano County, Colorado: U.S. Geological Survey Water-Supply Paper 1805, $91 \mathrm{p}$.

McLaughlin, T. G., Burtis, V. M., and Wilson, W. W., 1961, Records and logs of selected wells and test holes, and chemical analyses of ground water from wells and mines, Huerfano County, Colorado: Colorado Water Conservation Board Ground-Water Basic-Data Report 4, 26 p.

Powell, W. J., 1952, Ground water in the vicinity of Trinidad, Colorado [Prepared in cooperation with U.S. Geological Survey]: Denver, Colorado Water Conservation Board Ground-Water Circular 3, $28 \mathrm{p}$.

Repplier, F. N., Healy, F. C., Collins, D. B., and Longmire, P. A., 1981, Atlas of ground water quality in Colorado: Colorado Geological Survey Map Series 16.

U.S. Environmental Protection Agency, 1977a, Quality criteria for water: $256 \mathrm{p}$.

$1977 \mathrm{~b}$, National interim primary drinking wat'er regulations: EPA-570/9-76-003, 159 p.

Water, Waste, and Land, Ltd., 1980, Hydrology, geology, and water quality in vicinity of the Maxwell and Allen Mines, Las Animas County, Colorado: Final report to CF\&I Steel Corp. by Water, Waste, and Land, Ltd., Consultants to Mining, Agriculture, and Government, Fort Collins, Colo.

\section{Water Quality}

Brune, G. M., 1950, Dynamic concept of sediment sources: American Geophysical Union Transactions, v. 31 , no. 4 , p. 587-594.

Colorado Department of Health, 1980, Classifica- 
tions and numeric standards--Arkansas River basin: Colorado Department of Health, Water Quality Control Commission, $21 \mathrm{p}$.

Freeze, R. A., and Cherry, J. A., 1979, Groundwater: Englewood Cliffs, N.J., Prentice-Hall, Inc., $604 \mathrm{p}$.

Griggs, R. L., 1948, Geology and ground-water resources of the eastern part of Colfax County, New Mexico: New Mexico Bureau of Mines and Mineral Resources Ground-Water Report 1, 87 p.

Hadley, R. F., and Schumm, S. A., 1961, Sediment sources and drainage basin characteristics in upper Cheyenne River basin: U.S. Geological Survey Water-Supply Paper 1531-B, p. 137-196.

Hem, J. D., 1970, Study and interpretation of the chemical characteristics of natural water: U.S. Geological Survey Water-Supply Paper 1473, $363 \mathrm{p}$.

Howard, W. B., 1982, The hydrogeology of the Raton Basin, south-central Colorado: Indiana University, unpublished M.A. thesis, 95 p., appendices A-K.

Lusby, G. C., 1979 [1980], Effects of grazing on runoff and sediment yield from desert rangeland at Badger Wash in western Colorado, 1953-73: U.S. Geological Survey Water-Supply Paper 1532-I, 34 p., 1 pl.
National Academy of Scierices and National Academy of Engineering, 1973 [1974], Water-quality criteria 1972: U.S. Environmental Protection Agency EPA-R3-73-033, March 1973, 594 p.

New Mexico Water Quality Control Commission, 1977 , Water quality standards for interstate and intrastate streams in New Mexico: New Mexico Water Quality Control Commission, $38 \mathrm{p}$.

Smith, R. L., 1977, Elements of ecology and field biology: New York, Harper and Row, 495 p.

URS/Ken R. White Co., 1975, Arkansas River basin water quality management plan: Colorado Department of Health, Water Quality Control Division, v. I and appendix.

U.S. Environmental Protection Agency, 1977a, Quality criteria for water: $256 \mathrm{p}$. $1977 \mathrm{~b}$, National interim primary drinking water regulations: EPA-570/9-76-003, $159 \mathrm{p}$.

Wentz, D. A., 1974, Effect of mine drainage on the quality of streams in Colorado, 1971-72: Colorado Water Conservation Board Circular $21,117 \mathrm{p}$.

Wilhm, J. L., 1970, Range of diversity index in benthic macro-invertebrate populations: Water Pollution Control Federation Journal, v. 42, no. 5, pt. 2, p. R221-R224. 